\title{
ANÁLISE DA INFLUÊNCIA DO TEOR DE UMIDADE NA ABSORÇÃO D’ÁGUA E SUCÇÃO DOS SOLOS EM ESTUDOS DE ERODIBILIDADE
}

Dissertação apresentada à Escola de Engenharia de São Carlos, da Universidade de São Paulo, como complemento dos requisitos úteis à obtenção do título de Mestre em Geotecnia.

ORIENTADOR: Prof. Dr. Osni José Pejon

São Carlos

2010 
AUTORIZO A REPRODUÇÃO E DIVULGAČ̃̃O TOTAL OU PARCIAL DESTE TRABALHO, POR QUALQUER MEIO CONVENCIONAL OU ELETRÔNICO, PARA FINS DE ESTUDO E PESQUISA, DESDE QUE CITADA A FONTE.

Ficha catalográfica preparada pela Seção de Tratamento da Informação do Serviço de Biblioteca - EESC/USP

\footnotetext{
M543a Análise da influência do teor de umidade na absorçäo água e sucçáo dos solos em estudos de erodibilidade / Marla Bruna Melo de Menezes; orientador: Osni José Pejon. -- Säo Carlos, 2010.

Dissertaçäo (Mestrado-Programa de Pós-Graduaçäo e Area de Concentraçäo em Geotecnia) -- Escola de Engenharia de Säo Carlos da Universidade de Säo Paulo, 2010.

1. Erodibilidade. 2. Agua - absorçäo. 3. Suç̧ăo matricial. 4. Umidade do solo - teor. I. Titulo.
} 


\section{FOLHA DE JULGAMENTO}

Candidato(a): Engenheira MARLA BRUNA MELO DE MENEZES.

Dissertação defendida e julgada em 05/04/2010 perante a Comissão Julgadora:

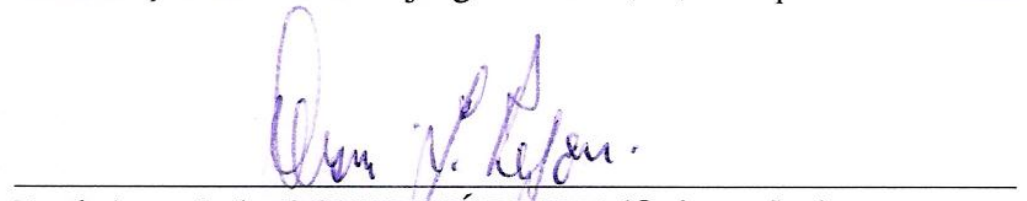

Prof. Associado OSNI JOSÉ PEJON (Orientador)

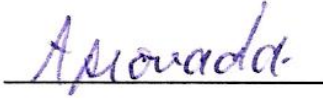

(Escola de Engenharia de São Carlos/USP)

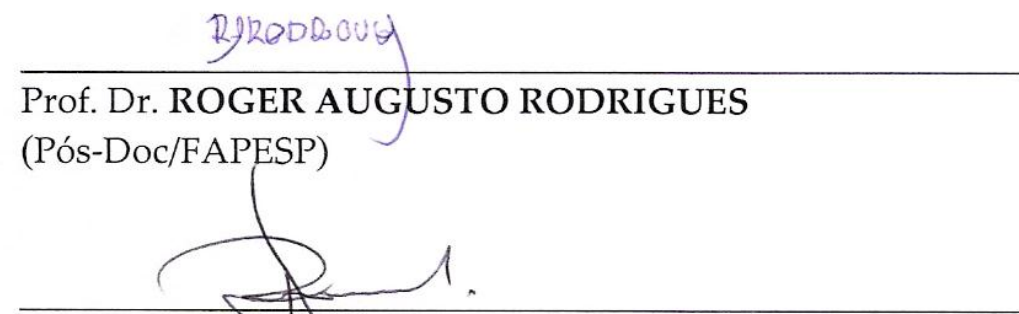

Prof. Dr. REINAIDO LORANDI

(Universidade Federal de São Carlos/UFSCar)
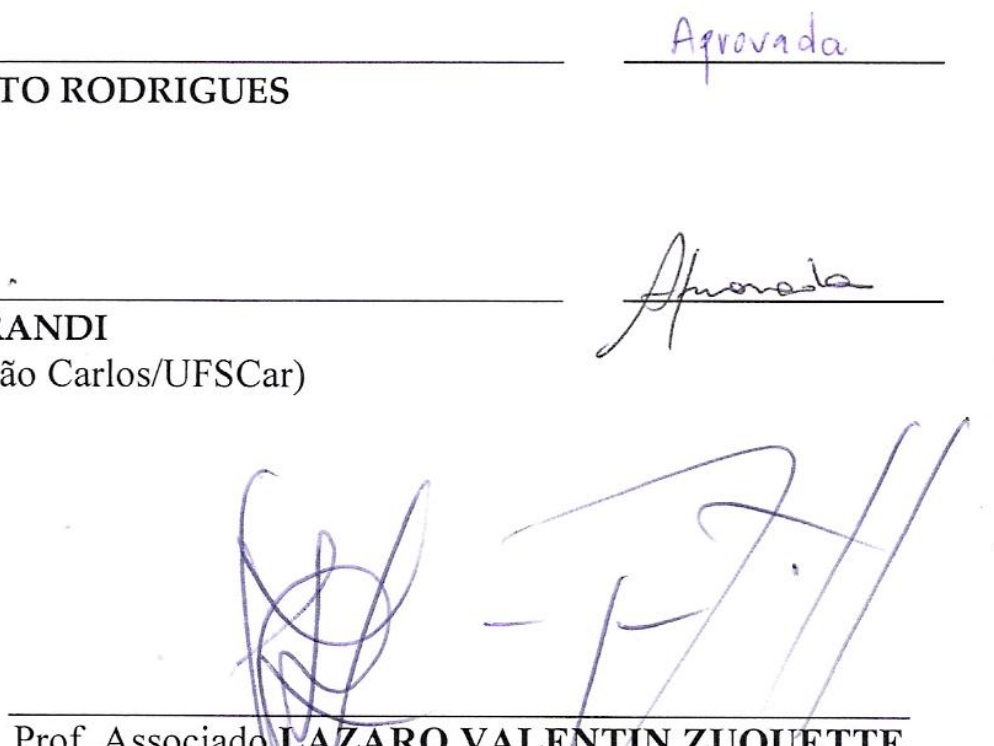

Prof. Associado LAZARO VALENTIN ZUQUETTE

Coordenador do Programa de Pós-Graduação em Geotecnia

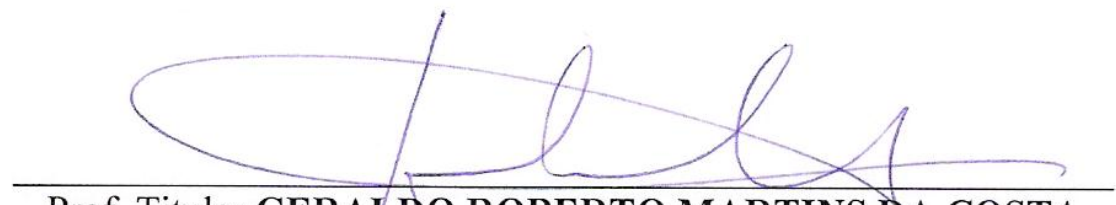

Prof. Titular GERALDO ROBERTO MARTINS DA COSTA

Presidente da/Comissão da Pós-Graduação da EESC 
Análise da influência do teor de umidade na absorção d'água e sucção dos solos em estudos de erodibilidade. 
Dedicatória

Ao meu Rei, Senhor e Amigo pessoal Jesus, o Cristo.

À sociedade;

aos meus pais Carlos e Val; aos meus avós Laudelino e Clara;

ao meu noivo Pedro; às minhas irmãs Perla e Eva. 
Análise da influência do teor de umidade na absorção d'água e sucção dos solos em estudos de erodibilidade. 


\section{Agradecimentos}

Mais uma vez, ao Deus em que creio, pois nunca me deixou faltar nada e sempre se mostrou um verdadeiro Amigo nessa trajetória.

Ao Prof. Dr. Osni J. Pejon, pela orientação e ajuda nas decisões a serem tomadas para conclusão deste trabalho. Ainda, pelas dicas e conselhos preciosos que me nortearam.

Ao Prof. Nelson Aoki, pela atenção, preocupação e amizade dispensadas a mim quando da prática das disciplinas.

Aos Profs., Orencio Monje Vilar, Benedito de Souza Bueno, José Eduardo Rodrigues, José Carlos Ângelo Cintra e Lázaro Valentin Zuquette, pelos ensinamentos durante as disciplinas e também por tornarem o Departamento de Geotecnia um ambiente descontraído $e$ acolhedor.

Aos Técnicos de Laboratório da EESC/USP, Sr. Antônio, Zé Luís, Décio e Oscar, sempre auxiliando nas etapas dos ensaios aqui realizados.

Aos funcionários do Departamento de Geotecnia, especialmente a Herivelto, Álvaro e Maristela.

Ao Prof. Dr. Roger Augusto Rodrigues, pelos conselhos, dicas e correções que ajudaram a nortear o objetivo deste trabalho; pelas experiências compartilhadas no decorrer dos ensaios com sucção controlada que permitiram entender melhor o tão velado comportamento dos solos não saturados; e pelas palavras de incentivo e força. A você, meu respeito, admiração e carinho.

Aos colegas que se fizeram amigos, Rafa Faciola, Deny Sasaki, Marcelinha Filizola, Dênis Delázari, Heraldo Pitanga, Jesús Daniel e Jesús Sánches. Aos amigos que se fizeram irmãos, Nane Vieira, Tio Maroldi, Flávia Florentino e Anderson Florentino.

À Maccaferri do Brasil pelo apoio no findar desta etapa.

Aos meus pais, exemplos de fé, humildade e perseverança.

Ao meu noivo Pedro Henrique Oliveira Amorim, pela compreensão, carinho, paciência e força. Obrigada pela crença depositada em nosso relacionamento! Te amo pra sempre!

Às famílias Melo e Menezes pelo amor. Amo vocês!

À Igreja Adventista de Placaford, Salvador, Bahia, pelas orações.

Ao CNPq, Conselho Nacional de Pesquisa e Desenvolvimento, pela concessão da bolsa de pesquisa. 
Análise da influência do teor de umidade na absorção d'água e sucção dos solos em estudos de erodibilidade.

" Nunca tive fartura que garantisse o futuro, mas Deus sempre me deu o suficiente que garantisse o presente." 
Análise da influência do teor de umidade na absorção d'água e sucção dos solos em estudos de erodibilidade. 


\section{SUMÁRIO}

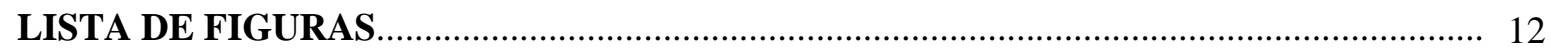

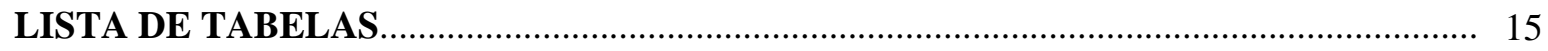

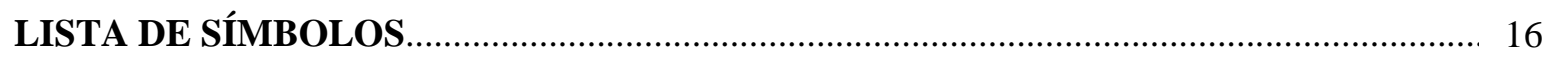

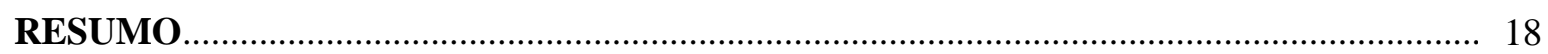

ABSTRACT

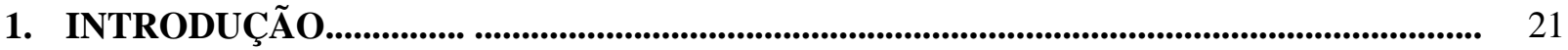

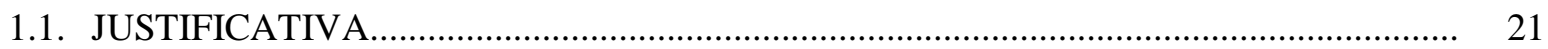

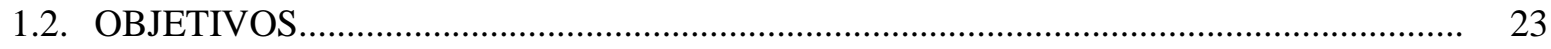

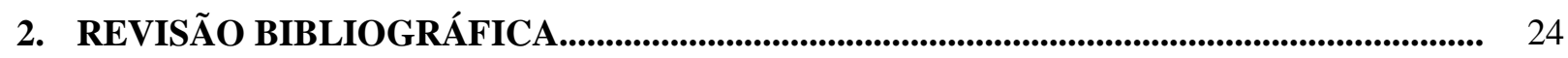

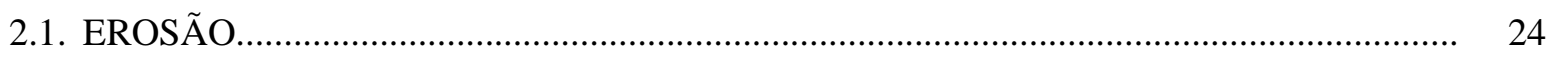

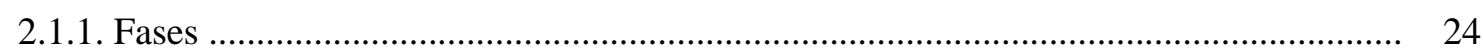

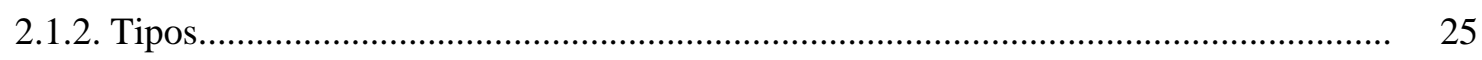

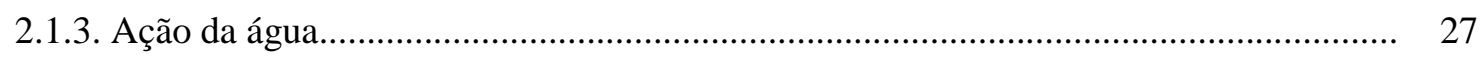

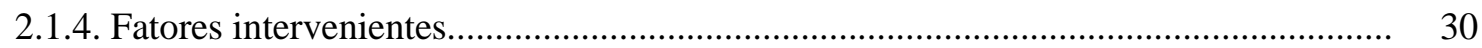

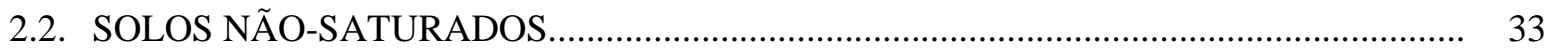

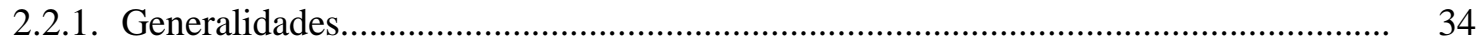

2.2.2. Sistema solo não saturado - atmosfera.................................................................. 36

2.2.3. Potencial da água no solo................................................................................... 37

2.2.3.1. Tensão de sucção .................................................................................. 39

2.2.3.2. Influência da sucção e do teor de umidade na erosão................................... 42

2.3. ERODIBILIDADE DOS MATERIAIS INCONSOLIDADOS.............................................. 43

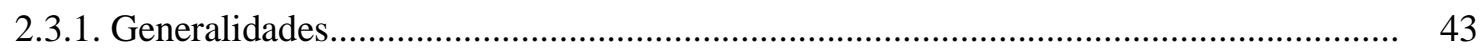

2.3.2. Suscetibilidade dos solos argilosos arenosos.......................................................... 45

2.3.3. Metodologias para determinação............................................................................... 46

2.3.4. Ensaio de Erodibilidade por Nogami \& Villibor (1979)............................................. 50

2.3.4.1. Ensaio de Absorção de água............................................................................ 52

2.3.4.2. Ensaio de Perda de massa por imersão............................................................. 52

2.4. MEDIDA E CONTROLE DA SUCÇÃO.................................................................... 53

2.4.1. Câmara de Pressão de Richards................................................................................. 56

2.4.2. Funil de Placa Porosa................................................................................................ 5

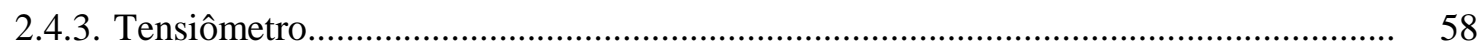

2.4.4. Método do Papel Filtro........................................................................................ 60 
2.5. CURVAS DE RETENÇÃO DE ÁGUA.................................................................... 62

3. MATERIAIS ESTUDADOS E CARACTERÍSTICAS DAS REGIÕES AMOSTRAIS....... 65

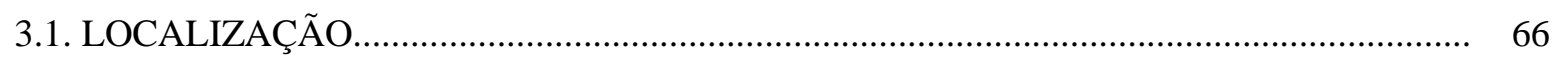

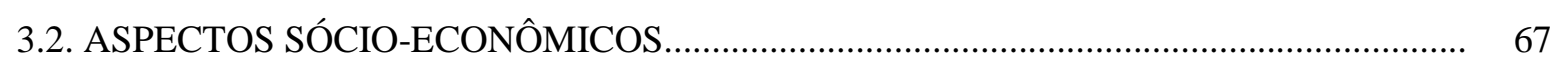

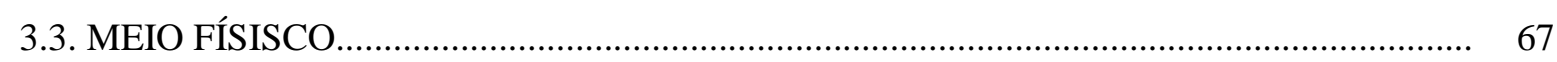

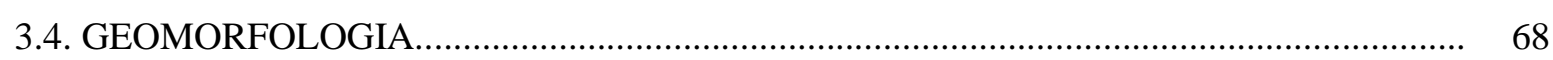

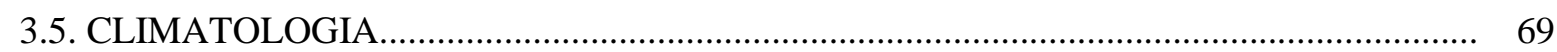

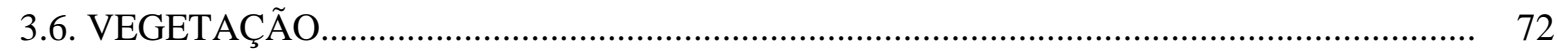

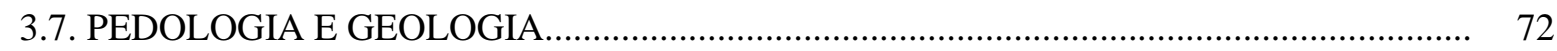

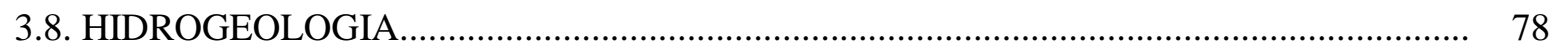

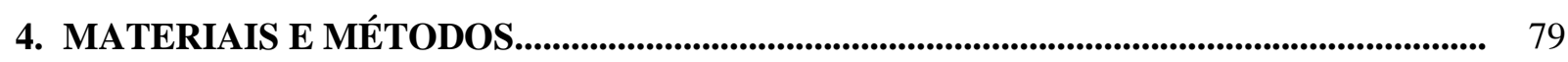

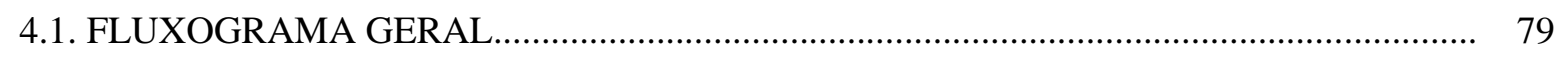

4.1.1. Etapas de Campo........................................................................................................ 79

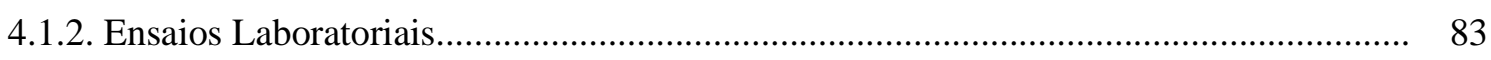

4.1.2.1. Ensaios de caracterização............................................................................... 83

4.1.2.2. Ensaios de laboratório para determinação das curvas de retenção de água............ 83

4.1.2.3. Ensaios de caracterização do comportamento hídrico............................................ 91

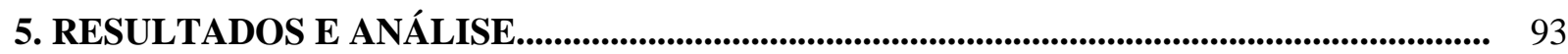

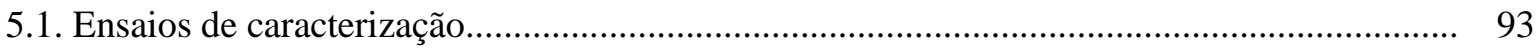

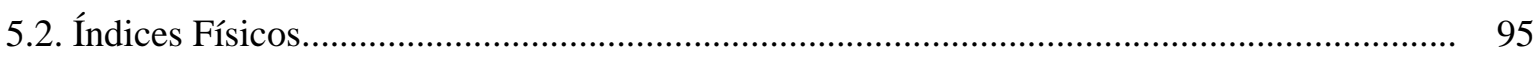

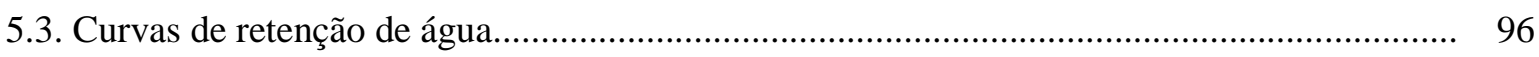

5.4. Curvas de absorção de água........................................................................................... 102

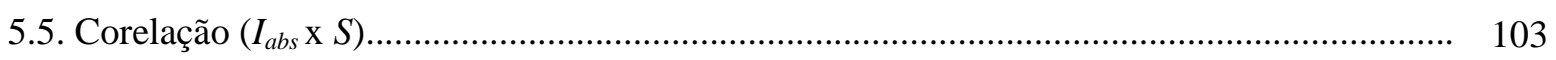

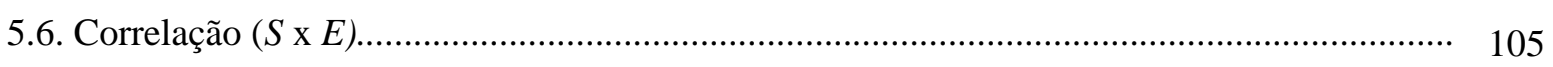

6. CONCLUSÕES.................................................................................................................................................. 106

REFERÊNCIAS BIBLIOGRÁFICAS................................................................................. 108

ANEXO 1 - Curvas de Absorção de água $\left(q x t^{0.5}\right)$ do Solo 1 geradas após ensaios de laboratório com sucção controlada.

ANEXO 2 - Curvas de Absorção de água $\left(q x t^{0.5}\right)$ do Solo 2 geradas após ensaios de laboratório com sucção controlada.

ANEXO 3 - Curvas de Absorção de água $\left(q x t^{0.5}\right)$ do Solo 3 geradas após ensaios de laboratório com sucção controlada 


\section{LISTA DE FIGURAS}

Figura 1 - Tipos de erosão (LAL, 1990 apud Alcântara, 1997).................................................... 25

Figura 2 - Distribuição das regiões mais susceptíveis às erosões (Teixeira et al., 2003)............. 27

Figura 3 - Morfologia de sulcos e boçorocas (São Pedro - SP).................................................... 29

Figura 4 - Impacto e efeito da gota da chuva........................................................................... 32

Figura 5 - Elemento de solo não saturado (Bueno \& Vilar, 1979)............................................... 35

Figura 6 - Fenômeno da Capilaridade (Rodrigues, 2007)........................................................... 35

Figura 7 - Ilustração do conceito do potencial total da água no solo (Vilar, 2000)..................... 38

Figura 8 - Ilustração dos conceitos de sucção (Vilar, 2000)....................................................... 41

Figura 9 - Ensaio de desagregação por imersão (Bastos, 2004).................................................... 48

Figura 10 - Aparelho de Inderbitzen (Ide, 2009)................................................................. 49

Figura 11 - Coleta de amostra no ensaio pinhole test (Camapum de Carvalho, 2006)................ 49

Figura 12 - Equipamento de pinhole test (Camapum de Carvalho, 2006).................................. 49

Figura 13 - Amostras após ensaio de pinhole test (Camapum de Carvalho, 2006)...................... 50

Figura 14 - Moldagem de corpo de prova.......................................................................... 51

Figura 15 - Secagem ao ar das amostras reduzidas............................................................... 51

Figura 16 - Equipamento de Absorção de Água (EESC - USP)................................................ 51

Figura 17 - Componentes do Ensaio de Absorção de Água......................................................... 52

Figura 18 - Ensaio de Perda de massa por imersão.................................................................... 53

Figura 19 - Câmara de Pressão de Richards (EESC - USP)................................................... 56

Figura 20 - Partes da Câmara de Pressão de Richards (Libardi, 1995 apud Pereira, 2004)........ 56

Figura 21 - Funil de placa porosa (modificado de Reichardt, 1985 apud Röhm, 2004).............. 57

Figura 22 - Esquema de um tensiômetro convencional (Gomes, 2007)...................................... 59

Figura 23 - Diferentes lotes do Papel Whatman $\mathrm{N}^{\circ} 42$ (Marinho, 2006).................................... 61

Figura 24 - Esquema de transferência de água do solo para o Papel Filtro.................................. 61

Figura 25 - Elementos da Curva de Retenção...................................................................... 63

Figura 26 - Curvas de Retenção para diferentes solos............................................................ 64

Figura 27 - Localização das regiões amostrais......................................................................... 66

Figura 28 - Divisão Geomorfológica do Estado de SP (modificado de Zuquette, 1981)............. 68

Figura 29 - Mapa de solos - Classificação Soil Taxonomy EUA (Teixeira et al., 2003)............. 73

Figura 30 - Feições Litoestratigráficas da Bacia Sedimentar do Paraná (Duarte, 1980).............. 74 
Figura 31 - Voçoroca na região de São Pedro. 75

Figura 32 - Arenito Pirambóia. Estrada Charqueada a São Pedro (Pejon, 1992)........................ 76

Figura 33 - Arenito silicificado Botucatu. Serra de São Pedro (Pejon, 1992)............................ 77

Figura 34 - Aquíferos: sedimentar Guarani e fraturado Serra Geral (CETESB, 2008).............. 78

Figura 35 - Fluxograma geral do estudo......................................................................... 79

Figura 36 - Coleta de amostra indeformada (escavação e selamento)....................................... 81

Figura 37 - Ponto de coleta Campus 2 (Solo 1)..................................................................... 81

Figura 38 - Ponto de coleta Facchina (Solo 2)........................................................................ 82

Figura 39 - Ponto de coleta S.Pedro (Solo 3) ..................................................................... 82

Figura 40 - Amostragem no interior de uma voçoroca (Solo 3)............................................ 83

Figura 41 - Sequência do ensaio de Papel Filtro............................................................... 84

Figura 42 - Equipamentos usados no Método do Papel Filtro (Rodrigues, 2007)...................... 85

Figura 43 - Sequência de Moldagem e pesagem dos corpos de prova....................................... 86

Figura 44 - Funil de Placa Porosa (EESC-USP).................................................................. 88

Figura 45 - Sequência do ensaio Câmara de Pressão de Richards.............................................. 90

Figura 46 - Montagem do ensaio de perda de massa............................................................ 92

Figura 47 - Coleta do solo despreendido no ensaio de perda de massa.................................... 93

Figura 48 - Curva Granulométrica do Solo 1 (Campus 2)....................................................... 94

Figura 49 - Curva Granulométrica do Solo 2 (Facchina)......................................................... 94

Figura 50 - Curva Granulométrica do Solo 3 (São Pedro)....................................................... 95

Figura 51 - Curva de retenção de água Solo 1....................................................................... 97

Figura 52 - Curva de retenção de água Solo 2 ....................................................................... 98

Figura 53 - Curva de retenção de água Solo 3 .................................................................... 98

Figura 54 - Curva de retenção de água ajustada Solo 1 - SWRC ............................................. 99

Figura 55 - Curva de retenção de água ajustada Solo 2 - SWRC ........................................... 100

Figura 56 - Curva de retenção de água ajustada Solo 3 - SWRC ............................................ 100

Figura 57 - Curva de absorção de água................................................................................... 102

Figura 58 - Relação entre o $I_{a b s}$ e a Sucção............................................................................. 104

Figura 59 - Relação entre a razão do $I_{a b s}$ pelo teor de umidade e a Sucção................................ 105

Figura 60 - Resultados para o Ensaio de Erodibilidade........................................................ 106

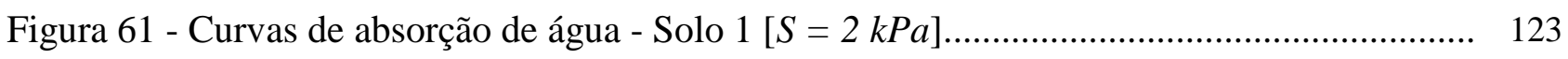

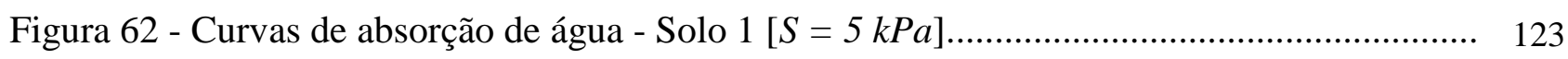


Figura 63 - Curvas de absorção de água - Solo $1[\mathrm{~S}=10 \mathrm{kPa}]$

Figura 64 - Curvas de absorção de água - Solo $1[S=20 \mathrm{kPa}]$

Figura 65 - Curvas de absorção de água - Solo $1[S=100 \mathrm{kPa}]$

Figura 66 - Curvas de absorção de água - Solo $1[S=200 \mathrm{kPa}]$

Figura 67 - Curvas de absorção de água - Solo $1[S=500 \mathrm{kPa}]$

Figura 68 - Curvas de absorção de água - Solo 1 [ $S=800 \mathrm{kPa}]$

Figura 69 - Curvas de absorção de água - Solo 1 (amostras secas ao ar) - [S> $800 \mathrm{kPa}$ ]

Figura 70 - Curvas de absorção de água - Solo $2[S=2 \mathrm{kPa}]$

Figura 71 - Curvas de absorção de água - Solo $2[S=5 \mathrm{kPa}]$

Figura 72 - Curvas de absorção de água - Solo $2[S=10 \mathrm{kPa}]$

Figura 73 - Curvas de absorção de água - Solo $2[S=20 \mathrm{kPa}]$

Figura 74 - Curvas de absorção de água - Solo $2[S=100 \mathrm{kPa}]$

Figura 75 - Curvas de absorção de água - Solo $2[S=200 \mathrm{kPa}]$

Figura 76 - Curvas de absorção de água - Solo $2[S=500 \mathrm{kPa}]$

Figura 77 - Curvas de absorção de água - Solo $2[S=800 \mathrm{kPa}]$

Figura 78 - Curvas de absorção de água - Solo 2 (amostras secas ao ar) - $[S>800 \mathrm{kPa}] \ldots \ldots \ldots \ldots . . .133$

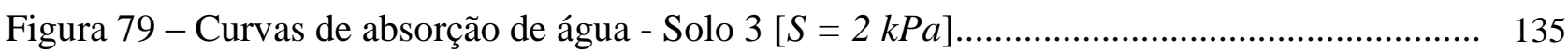

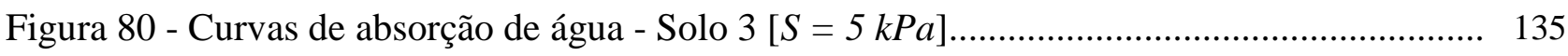

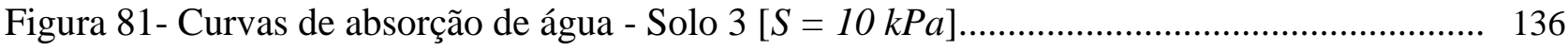

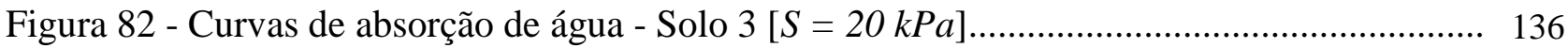

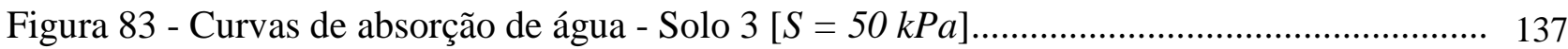

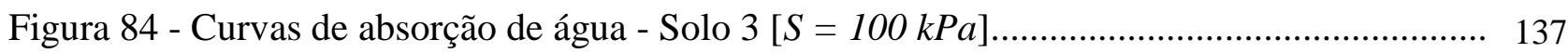

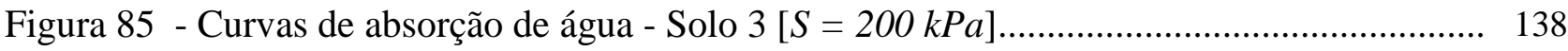

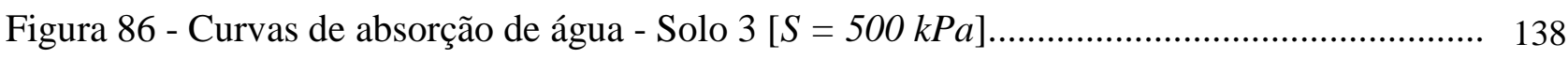

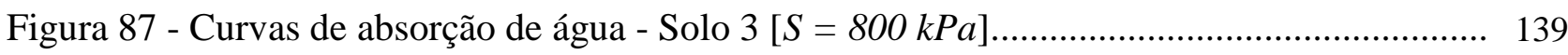

Figura 88 - Curvas de absorção de água - Solo 3 (amostras secas ao ar) - $[S>800 \mathrm{kPa}] \ldots \ldots \ldots \ldots . . .139$ 


\section{LISTA DE TABELAS}

Tabela 1 - Métodos de medida de sucção por Vilar, 2000 (continuação)................................... 53

Tabela 2 - Altimetria em relação ao nível do mar (adaptada de Tolentino 1967)...................... 69

Tabela 3 - Normais climatográficas de São Carlos (Tolentino 1967 e Unicamp Cepagri 2008).. 70

Tabela 4 - Absorção de água versus silificação do Arenito Botucatu (Oliveira et al., 1981)...... 74

Tabela 5 - Classificação granulométrica NBR 6502/95 ....................................................... 92

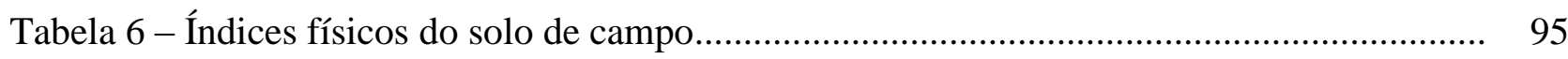

Tabela 7 - Pontos experimentais obtidos nos ensaios com controle de sucção........................... 96

Tabela 8 - Parâmetros de ajuste das curvas de retenção de água por Van Genutchen (1980)...... 100

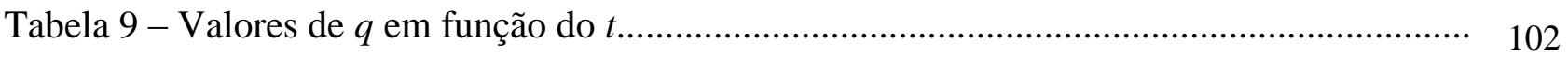

Tabela 10 - Valores de Índices de absorção dos solos......................................................... 102

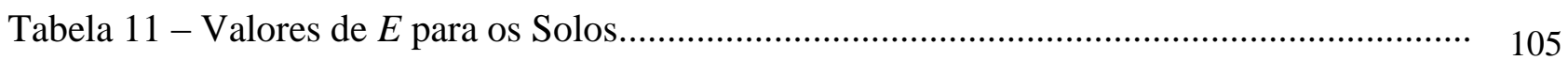




\section{LISTA DE SÍMBOLOS}

\section{Símbolos do alfabeto latino}

Cv : coeficiente de variação

e : índice de vazios

E : índice de erodibilidade (Nogami \& Villibor, 1979)

$h_{c}$ : altura da ascensão capilar

$I_{a b s}:$ índice de absorção de água

$n$ : porosidade

$P$ : percentual de massa perdida por imersão

$P_{\text {atm }}$ : pressão atmosférica

$P_{\text {suc }}:$ pressão de sucção

$q$ : volume de água absorvido pela área do corpo de prova

$R_{S}$ : raio de curvatura da membrana contráctil

$S:$ sucção matricial

$S_{o}:$ sucção osmótica

$S_{r}$ : grau saturação inicial

$S_{t}:$ sucção total

$t$ : tempo de absorção

$T_{S}$ : tensão superficial na água capilar

$u$ : pressão de sucção

$u_{a}$ : pressão no ar dos poros

$u_{w}$ : pressão na água dos poros

$w:$ umidade gravimétrica

$w_{\text {mold }}:$ umidade de moldagem

$w_{\text {sat }}$ : umidade de saturação

\section{Símbolos do alfabeto grego}

$\alpha$ : ângulo de interseção da membrana com as paredes do tubo

$\triangle_{U}:$ diferença de pressões na interface ar-água 
$\Phi:$ potencial total da água no solo

$\Phi_{M}:$ componente matricial

$\Phi_{T}:$ componente de temperatura

$\Phi_{O}:$ componente osmótico

$\Phi_{P}:$ componente de pressão

$\Phi_{Y K}:$ outros componentes

$\gamma_{w}$ : peso específico da água

m: média dos índices físicos

$\theta_{S}:$ umidade volumétrica de saturação

$\theta_{r}:$ umidade volumétrica residual

$\rho:$ massa específica natural

$\rho_{d}:$ massa específica seca

$\rho_{S}:$ massa específica dos sólidos

$\sigma:$ desvio padrão 


\section{RESUMO}

MENEZES, M. B. M. de (2010). Análise da influência do teor de umidade na absorção d'água e sucção dos solos em estudos de Erodibilidade. São Carlos, 116p. Dissertação de Mestrado - Escola de Engenharia de São Carlos, Universidade de São Paulo

O estudo da erodibilidade ganha importância quando se tratam de solos localizados em regiões tropicais, caracterizadas por altas pluviosidades e evaporações que dificilmente permitem ao maciço atingir um estado de saturação em campo. A erodibilidade e as propriedades hidráulicas determinam as condições de infiltração e de escoamento superficial e podem acelerar as feições erosivas através das perdas de partículas. Neste trabalho, observouse que o grau de saturação in situ estabelece um potencial de sucção matricial $\left(S_{m}\right)$ capaz de orientar o fluxo, absorção e armazenamento da água nos poros do solo. Deste modo, foi possível correlacionar as propriedades de absorção de água com as sucções mátricas de três solos (arenoso, argiloso e areno-argiloso), com comportamento erosivo e não-erosivo, ensaiados a diferentes teores de umidade inicial. Após o controle da sucção e umidade, através da Panela de Pressão de Richards, os solos foram submetidos ao Ensaio de Erodibilidade proposto por Nogami \& Villibor (1979). Os Índices de absorção $\left(I_{a b s}\right)$, de perda de massa por imersão $(P)$ e de erodibilidade $(E)$ determinados neste ensaio, quando correlacionados com as curvas características dos solos, mostraram a influência da sucção matricial no início do processo erosivo. Verificou-se uma tendência de aumento da perda de massa por imersão, quanto menor era o teor de umidade inicial imposta (maior sucção). Provavelmente, quando do início do evento chuvoso, o solo tende a ser mais erodível quanto mais seco estiver. Além disso, as correlações obtidas mostraram-se coerentes com o comportamento dos solos em estudo, permitindo uma estimativa da sucção $\left(S_{m}\right)$ de um solo a partir de grandezas facilmente mensuráveis como o $I_{a b s}$, obtido em ensaio simples e de fácil execução.

PALAVRAS-CHAVE: Erodibilidade; absorção de água; sucção; teor de umidade. 


\begin{abstract}
MENEZES, M. B. M. de (2010). Analysis of the influence of moisture content on water absorption and suction in soil studies Erodibility. São Carlos, 116p. M.Sc Dissertation Escola de Engenharia de São Carlos, Universidade de São Paulo.

The study of erodibility gains importance when dealing with soil located in tropical regions, characterized by high precipitation and evaporation that allow hardly the massive soil to reach a state of saturation in the Field. The erodibility and hydraulic properties define the infiltration conditions and the superficial flow, and they can accelerate the the erosive process due to the losses of particles. In this work, we observed that the degree of saturation in situ establishes the potencial for suction matrix $\left(S_{m}\right)$ can guide the flow, absorption and storage of water in soil pores. Therefore, experimentally, it was possible to correlate the properties of water absorption with the matrix suctions of three soils, with different initial moisture contents and erosive and non-erosive behaviors. After controlling the suction and moisture through the pressure Richards Pressure Chamber the soils were subjected to the Erodibility test proposed by Nogami \& Villibor (1979). The indexes of absorption $\left(I_{a b s}\right)$, mass loss by immersion $(P)$ and erodibility $(E)$ determinated in this experiment, when correlated with the characteristic curves of soils, showed the influence of matrix suction at the beginning of the erosion process. There was a trend of increased weight loss by immersion, the lower was the initial moisture content imposed (greater suction). Furthermore, the correlations obtained were consistent with the behavior of soils under study, allowing to estimate of suction $\left(S_{m}\right)$ of a soil from easily measurable values such as the $I_{a b s}$.
\end{abstract}

KEYWORDS: Erodibility; water absorption; soil suction; moisture content. 
Análise da influência do teor de umidade na absorção d'água e sucção dos solos em estudos de erodibilidade. 


\section{INTRODUÇÃo}

O uso e manuseio inadequados do solo começaram a ser objeto de discussões mais intensivas a partir da década de 30 quando as alterações no equilíbrio geomorfológico foram diretamente associadas à intervenção humana, através do desmatamento, práticas agrícolas e urbanas. Como conseqüência imediata dessas intervenções tem-se a erosão ou corrosão (do latim erode) geralmente classificada em normal e acelerada (DAEE, 1990). A primeira atua formando e erodindo os solos conferindo, até certo ponto, um equilíbrio e normalidade à natureza. Enquanto, se o solo é produto do desequilíbrio das ações naturais e antrópicas, sofre uma erosão acelerada, e não consegue se regenerar.

Por vezes, a erosão é tratada de forma holística tentando ser explicada pela interação de agentes como a ação das águas, o tipo de substrato e a intervenção humana. Mas, tem-se observado a preocupação com alguns aspectos antes tratados genericamente. Destacam-se hoje, por exemplo, a caracterização geotécnica dos materiais inconsolidados das áreas afetadas e o fluxo da água no solo segundo as variações do potencial total (Vertamatti, 1990; Pereira, 1994; Carvalho, 1997; Motta, 2001; Bastos, 2004; Cavalhero, 2005; Ide, 2009).

Dos fatores que influenciam a erosão, aqui foram estudadas as propriedades do solo que refletem sua resistência quando sob a ação de agentes erosivos, retratando sua erodibilidade. Esta susceptibilidade à erosão tem relação direta com as propriedades de destacabilidade e transportabilidade das partículas do solo, associadas, respectivamente, às forças de natureza superficial, e às características físicas como tamanho e forma das partículas (Vilar, 1987; Pejon, 1992). A magnitude da erodibilidade depende do tipo de solo. Materiais finos costumam ser menos erodíveis que os grossos, pois a destacabilidade de suas partículas é dificultada pelas forças de coesão. No caso dos solos grossos, dificilmente existem forças de coesão, no máximo uma coesão aparente que não impede a destacabilidade dos grãos.

A erodibilidade pode ser medida por diferentes ensaios laboratoriais e ter avaliação direta ou indireta para sua quantificação, como relatado nos trabalhos de Bryan (1969); Nogami \& Villibor (1979); Ângulo (1984); Vilar (1987); Denardin (1990); Cavalieri (1994); Alcântara (1997); Pejon \& Silveira (2006). Seu estudo se justifica quando se tratam de solos localizados em região de clima tropical, onde o intemperismo químico predomina formando os solos não saturados, cuja característica principal é a ocorrência de água e ar em seus vazios em quantidade que varia de acordo com os teores de umidade de campo. 


\subsection{Justificativa}

Um panorama histórico da erosão foi traçado por Mortari (1994) quando mostrou que a erosão acelerada não é um fenômeno novo e de épocas recentes. Segundo ele, é provável que já existisse a 4.000 A.C. nos vales Eufrates e Nilo, porém não representando os perigos atuais, já que se tratavam de pequenas áreas cultivadas com baixas concentrações demográficas.

Com o crescimento da população e das áreas destinadas às práticas extrativas, a problemática da erosão passou a ser questão mundial. Exemplo deste avanço foi a estimativa feita pela ONU, na década de 60, de que na Europa cerca de $22 \%$ das terras estavam em desuso por causa da erosão. Na América do Sul os dados não foram diferentes, alguns países chegaram a apresentar 25\% dos seus territórios com indícios de erosão (Mortari, 1994). No Brasil existe ainda um fator agravante que é o clima tropical úmido, caracterizado pelos altos índices pluviométricos que favorecem a ação erosiva da água .

Em particular, no Estado de São Paulo, a erosão vem gerando pesados prejuízos para a sociedade, através da perda tanto de solos agricultáveis, quanto de investimentos públicos em obras de infra-estrutura e de degradação de áreas urbanas ou em urbanização. No ínicio da década de 90 foram estimadas cerca de 3.000 voçorocas no Estado; sendo diagnosticadas 7.000 voçorocas ao fim deste período, com pelo menos $80 \%$ das terras cultivadas sofrendo processo erosivo além dos limites de recuperação natural do solo (DAEE, 1990; DAEE, 2009).

O custo das obras corretivas necessárias à estabilização destas feições erosivas atingiria cerca de $20 \%$ do orçamento do Estado. O que demandariam altos investimentos com ações corretivas que como soluções unitárias não impediriam a aceleração de novos efeitos deletérios (DAEE, 1990).

Este sucinto quadro da problemática da erosão explica o avanço nos estudos sobre o assunto e a vasta literatura disponível. Justifica-se, portanto, a necessidade de utilizar os conhecimentos geológico-geotécnicos a fim de prever e minimizar os impactos da erosão dos solos, visto que a recuperação proveniente do equilíbrio natural é tardia e não soluciona os inúmeros problemas geotécnicos.

A previsão do comportamento de um solo, na iminência da erosão, usando-se parâmetros conhecidos e parâmetros a serem determinados foi a motivação deste trabalho. Esta pesquisa, que se trata de um estudo recente e sem relatos na literatura, busca relacionar o 
fenômeno erosivo às suas causas intrínsecas, entendendo a Erodibilidade e incorporando os conceitos da Mecânica dos Solos não-saturados.

\subsection{Objetivos}

As propriedades de resistência, variações volumétricas e permeabilidade dos solos nãosaturados estão diretamente relacionadas com os teores de umidade in situ cujas variações determinam seus potenciais de sucção matricial e de absorção de água.

Os processos erosivos dependem desses fenômenos, visto que, a capacidade de retenção de água dos solos determinará seu poder de infiltração e futuras condições de escoamento superficial, pois quanto mais água infiltrar menor quantidade estará disponível para escoar na superfície e corroer o maciço.

Esta pesquisa objetiva relacionar a erodibilidade com os conceitos da mecânica dos solos não-saturados correlacionando as propriedades intrísecas dos solos com suas propriedades de infiltração e capacidade de absorção, para diferentes teores de umidade possíveis.

Para tanto, este trabalho se propõe a:

- conhecer os materiais através dos ensaios de caracterização;

- caracterizar o comportamento hídrico destes solos através das curvas de retenção de água, obtidas em ensaios específicos;

- levantar informações sobre a susceptibilidade à erosão de diferentes solos do interior de São Paulo;

- analisar a influência do teor de umidade inicial dos solos nos fenômenos de retenção de água;

- mensurar a erodibilidade desses solos conforme os diferentes teores de umidade inicial;

- analisar as relações entre a absorção de água, os teores de umidade e potencial de sucção matricial destes materiais;

- $\quad$ segundo as correlações obtidas, tornar possível prever a sucção a partir do Índice de Absorção $\left(I_{a b s}\right)$, parâmetro resultante do Ensaio de Absorção de Água, proposto por Nogami \& Villibor (1979) na identificação de materiais inconsolidados erodíveis. 


\section{REVISÃO BIBLIOGRÁFICA}

\subsection{EROSÃO}

Erosão vem do Latin "erosio" ou "erode", que significa, corroer, separar. Em termos gerais, erosão do solo significa a remoção física do topo do solo por vários agentes, incluindo a queda de pingo de chuva, escoamento da água na superfície e no interior do perfil do solo, vento, gelo e arraste gravitacional (LAL, 1990 apud Miranda, 2005).

Vilar (1993) acrescenta que a erosão consiste em um conjunto de processos pelos quais os materiais da crosta terrestre são desagregados, dissolvidos ou desgastados e transportados de um ponto a outro pelos agentes erosivos, tais como as geleiras, os rios, os mares, o vento ou a chuva.

Bigarella (1985) aprofunda o conceito de erosão quando estuda a problemática e diz que esta deve ter como fundamento principal o conhecimento da dinâmica da água proveniente de precipitações pluviométricas após entrar em contato com o solo, momento em que inicia sua ação mecânica, através do transporte de partículas. Ainda salienta que o sucesso do controle dos processos erosivos está no conhecimento aprofundado de suas fases.

\subsubsection{Fases}

Ocorrem três fases básicas: destacamento, transporte e deposição das partículas do solo; sendo a energia para este trabalho fornecida pelos agentes erosivos, cuja magnitude e taxa de dissipação determinam a severidade dos processos erosivos. As fontes principais desta energia são: física (vento e água), gravidade, química (reações) e antropogênicas.

O despreendimento da fração sólida (minerais, matéria orgânica e sais) na erosão hídrica pode se dar devido ao impacto das gotas de chuva, à atuação das forças de percolação da água, às propriedades químicas da água e às instabilizações de taludes (LAL 2001, apud Silva, 2003; Camapum de Carvalho, 2006).

Mortari (1994) discorre sobre as principais fases da erosão, detalhando-as a fim de diferenciá-las, pois considera que nem sempre estas são muito distintas umas das outras, independente do agente erosivo.

Já Idorchuck (1999) apud Silva (2003), sugere a existência de dois estágios no desenvolvimento de feições erosivas, os quais são controlados por diferentes grupos de processos geomorfológicos: 
- Estágio Inicial: a erosão hídrica é predominante no leito da erosão e rápidos movimentos de massa ocorrem nos lados desta feição erosiva; a formação de canais é muito intensa, devido às características morfológicas ainda não se encontrarem estáveis (comprimento, largura, área e volume);

- Estágio Final: o transporte de sedimentos e a sedimentação são os principais processos no leito da erosão; sua largura aumenta devido a erosão lateral e movimentos de massa lentos transformam os lados da feição erosiva

\subsubsection{Tipos}

As erosões podem ser classificadas em diferentes tipos e, segundo Camapum de Carvalho (2006), tal classificação depende da forma como surgiram, se por fator natural ou por interferência antrópica. Muitos autores propõem terminologias para a classificação dos processos erosivos. Na Figura 1, LAL (1990), apud Alcântara (1997) esquematiza uma classificação dos tipos de erosão segundo os principais agentes.

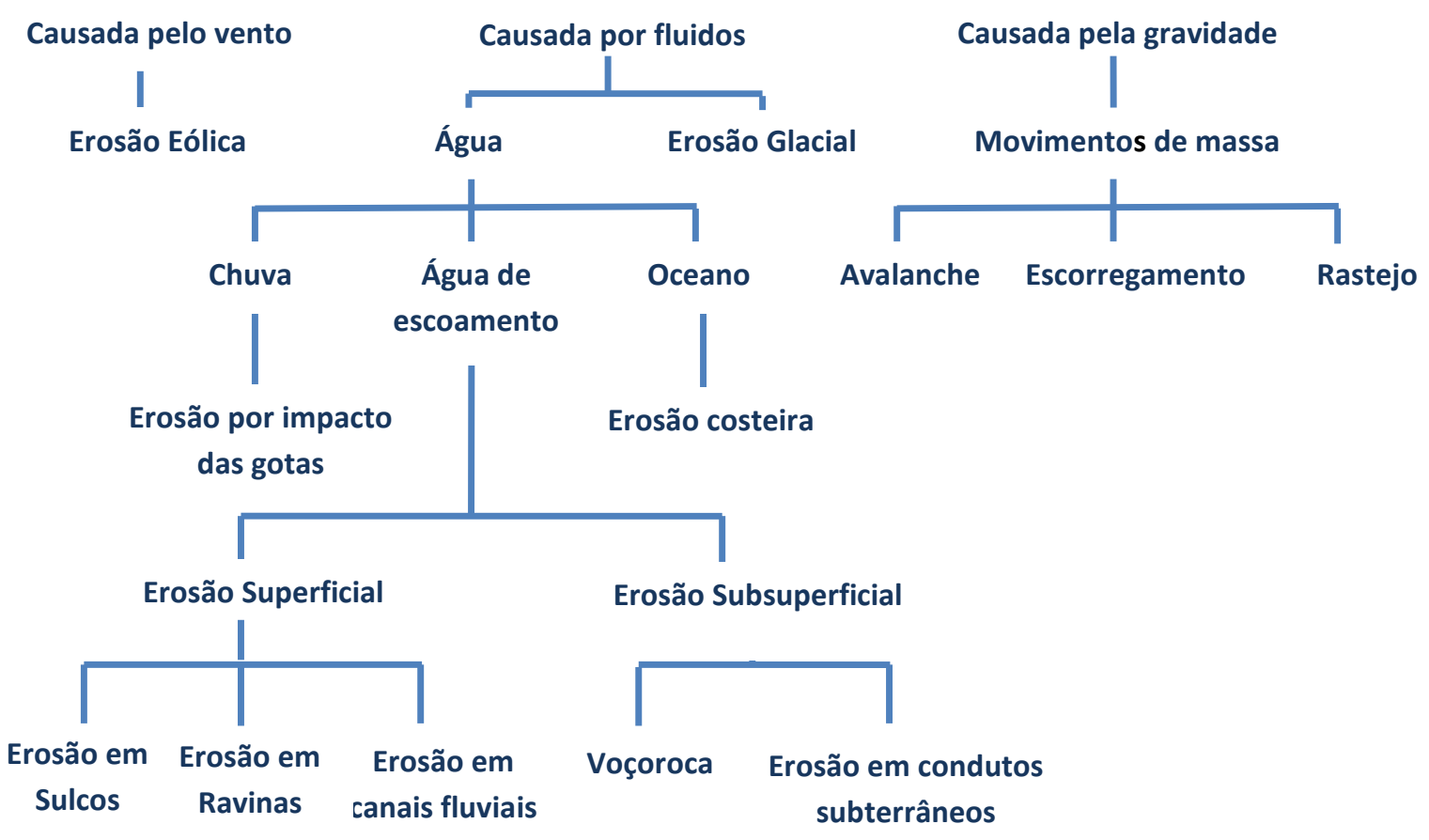

Figura 1 - Tipos de erosão (LAL, 1990 apud Alcântara, 1997) 
Existem diferentes divisões dos processos erosivos segundo vários autores que consideram a Erosão Hídrica um dos processos mais comuns existentes na superfície terrestre, podendo se apresentar como uma forma de desgaste e suavização da topografia, classificandose como erosão natural, geológica ou normal. Contudo, quando o equilíbrio natural é afetado, a dinâmica ganha velocidade e passa a denominar-se erosão acelerada (Vilar, 1987; Silva, 2003).

A erosão natural acontece quando a atuação dos processos erosivos se faz em ambiente onde é controlada somente pelo equilíbrio dos fatores naturais, se processando lentamente ao longo do tempo geológico. Em resumo, refere-se ao processo que ocorre naturalmente, sem influência antrópica. Também, pode apresentar intensidades que variam desde a erosão não aparente, onde o solo não apresenta sinais perceptíveis de erosão, até a extremamente forte, onde os horizontes A e $\mathrm{B}$ foram totalmente removidos e o $\mathrm{C}$ foi atingido por sulcos profundos, segundo Vertamatti (1990) e Pejon (1992).

Bigarella (1985) considera basicamente três tipos de erosão: erosão laminar, ravinamentos e voçorocas.

- Erosão Laminar: quando o escoamento superficial se distribui pela encosta de forma dispersa, não se concentrando em canais;

- Erosão em Ravinas: quando o escoamento superficial se torna canalizado;

- Erosão em Voçorocas: relacionadas ao alargamento e aprofundamento das ravinas, sendo que algumas têm sua origem na erosão causada pelo escoamento subsuperficial. Miranda (2005), citando outros autores, resumiu outros tipos de feições em:

- Intersulco: que é causada pelo escoamento superficial, representado por uma lâmina de água de pequena espessura e extensão que se concentra em determinadas áreas como, por exemplo, entre os sulcos já formados pelos processos erosivos (Meyer et al.,1975 apud Souza, 2001);

- Piping: termo utilizado para designar erosão interna ou tubular, que provoca a remoção de partículas no interior do solo, formando canais que evoluem em sentido contrário ao do fluxo da água (Carson \& Kirkby, 1975);

- Erosão Marginal: formas erosivas causadas pelo escoamento concentrado nos cursos d’água, dispõem-se transversais ao eixo do fluxo; 
Lima (2003) mencionou a esqueletização como um tipo de processo que contribui para a evolução da erosão pois promove a degradação física do solo aumentando sua porosidade e, surge em conseqüência do transporte de partículas ou elementos químicos solubilizados. $\mathrm{O}$ autor enfatiza que esse tipo ainda é pouco estudado no Brasil e quase sempre não é considerado na análise dos processos erosivos.

Outros tipos de formas particulares de erosão são citadas como: erosão em pedestal; erosão em pináculo; erosão da fertilidade do solo. O mais comum é, no entanto, classificar a erosão em quatro grandes grupos: erosão hídrica, erosão eólica, erosão glacial e erosão organogênica (Camapum de Carvalho, 2006).

\subsubsection{Ação da água}

A ação da água no solo é o principal mecanismo da dinâmica hidrológica, pois é responsável pela deflagração de processos erosivos, assoreamento de canais e movimentações de massa ocasionando impactos socioambientais e econômicos de significativa expressão A água se destaca em relação aos outros agentes erosivos pois se apresenta de diferentes formas. Além disso, a distribuição potencial dos processos de alteração da superfície terrestre, em função dos parâmetros climáticos atuais, está diretamente relacionada à presença da água, (Molinari, 2005; Teixeira et al., 2003).
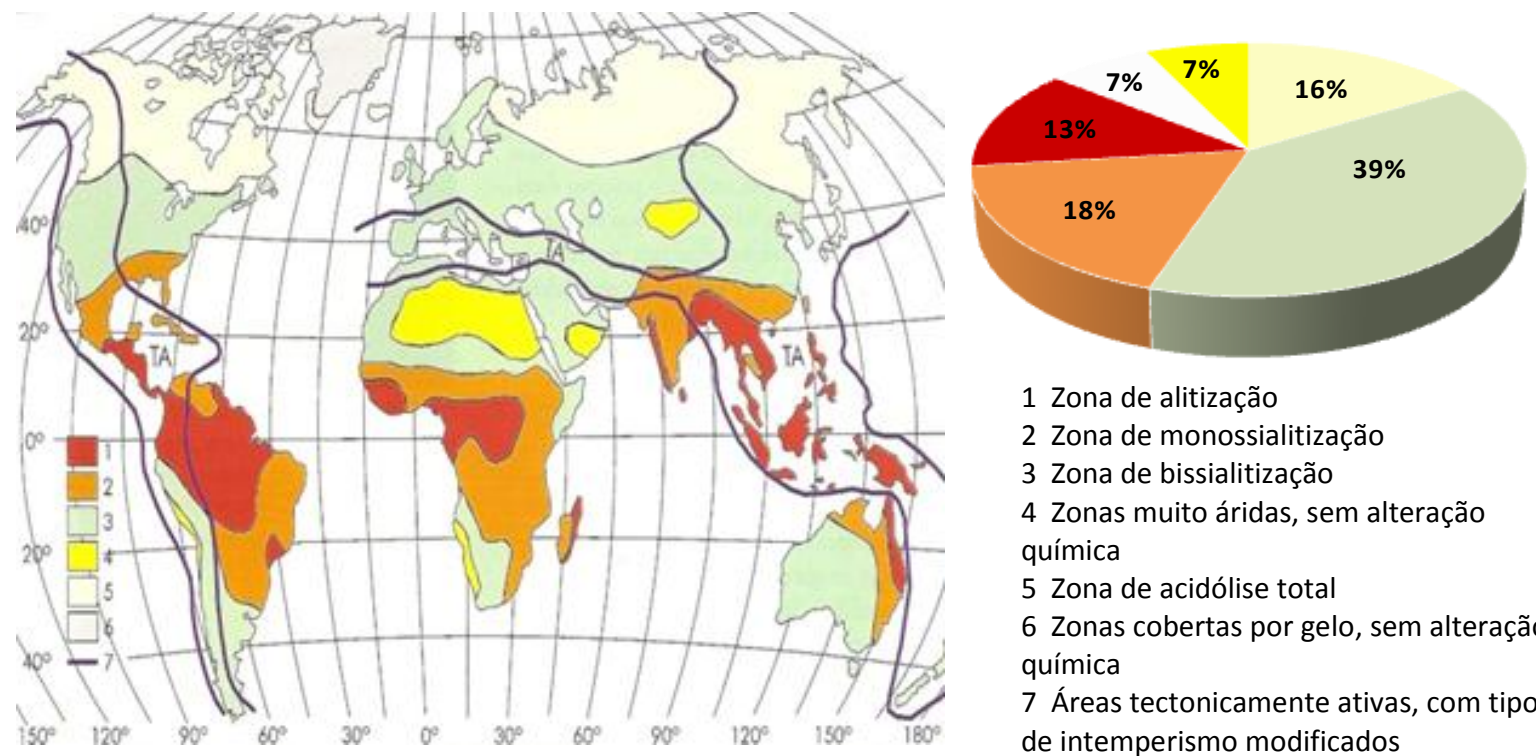

1 Zona de alitização

2 Zona de monossialitização

3 Zona de bissialitização

4 Zonas muito áridas, sem alteração química

5 Zona de acidólise total

6 Zonas cobertas por gelo, sem alteração química

7 Áreas tectonicamente ativas, com tipos de intemperismo modificados

Figura 2 - Distribuição das regiões mais susceptíveis às erosões (modificado de Teixeira et al., 2003) 
Conforme apresentado na Figura 2, as regiões sem alteração química correspondem a $14 \%$ da superfície e são àquelas caracterizadas por uma carência total de água no estado líquido que pode ser explicada por dois motivos: água congelada nas regiões polares; secura extrema pela ausência de chuva nas regiões desérticas.

Em contrapartida, as regiões com alteração química correspondem a $86 \%$ da superfície dos continentes submetidas às condições de climas mais severos e, portanto mais susceptíveis aos processos erosivos, correspondem às áreas do globo que são caracterizadas por uma certa umidade motivadora dos fenômenos intempéricos. A erosão pode ocorrer à medida que os processos de intemperismo desagregam ou decompõem as rochas, mantendo-se a superfície do terreno praticamente desprovida de solos, nela aflorando a rocha, segundo informações de Bigarella (1985), Teixeira et al. (2003) e Rodrigues (1982).

Os fenômenos erosivos que atingem os solos, ou mais propriamente o manto de intemperismo, agem de duas formas distintas. Numa delas, o ataque da água atinge o solo na superfície desagregando-o, a fim de facilitar o transporte das partículas menores. Na outra, a ação verifica-se não só na superfície, como também, em subsuperfície, numa determinada porção do perfil, isto é, afetando uma massa de material inconsolidado.

Caso a erosão se desenvolva por influência não somente das águas superficiais (sulcos e ravinas), mas também dos fluxos d'água subsuperficiais, em que se inclui também o lençol freático, configura-se o processo mais conhecido por voçoroca ou boçoroca (Figura 3); termo que provém do tupi mboso'roka que significa romper ou rasgar (Oliveira et al. 1998).

Em se tratando de regiões de clima tropical, como já exposto, a forma mais conhecida de erosão hidríca é a pluvial, devido tanto à sua abrangência, quanto aos prejuízos que acarreta. Por definição, Bazzano (2007) complementa que a erosão hídrica é a consequiência da interação da chuva com o solo, ou seja, é a resultante do poder da chuva em causar erosão e da capacidade do solo em resistir a esta.

De acordo com Carson \& Kirkby (1975) apud Nishiyama (1991), a água da chuva ao alcançar a superfície do terreno se subdivide em vários componentes. Parte da chuva que é interceptada pela vegetação, permanece sobre a superfície foliar e posteriormente evapora, enquanto que o restante chega à superfície do solo por gotejamento após sofrer um retardamento. Ao potencial da chuva em causar erosão chama-se erosividade que é um importante parâmetro para a quantificação de perdas de solo. 
Parte da água da chuva que atinge a superfície do terreno, direta ou indiretamente, preenche pequenas irregularidades da superfície, produzindo o armazenamento superficial; outra parte percola no solo; e uma terceira parcela produz o escoamento superficial. A água que percola através da superfície do solo pode ser incorporada neste sob forma de umidade, ou então, continuar percolando até atingir o nível d'água. Coelho Netto (1994) também disserta sobre a infiltrabilidade da água no solo e o escoamento subsuperficial.

No entanto, o solo possui uma capacidade limite de absorção de água, ou seja, nem toda água da chuva consegue penetrar no solo. Enquanto a intensidade da precipitação é menor que a capacidade de infiltração calculada, toda chuva infiltra (Silveira et al.,1993).

A capacidade ou taxa de infiltração é o índice volumétrico de quanto o solo pode receber umidade entre seus poros. Este índice pode representar tanto o potencial que o solo tem de absorver água pela sua superfície, em termos de lâmina por tempo; quanto a taxa real de infiltração que acontece quando há disponibilidade de água para penetrar no solo.

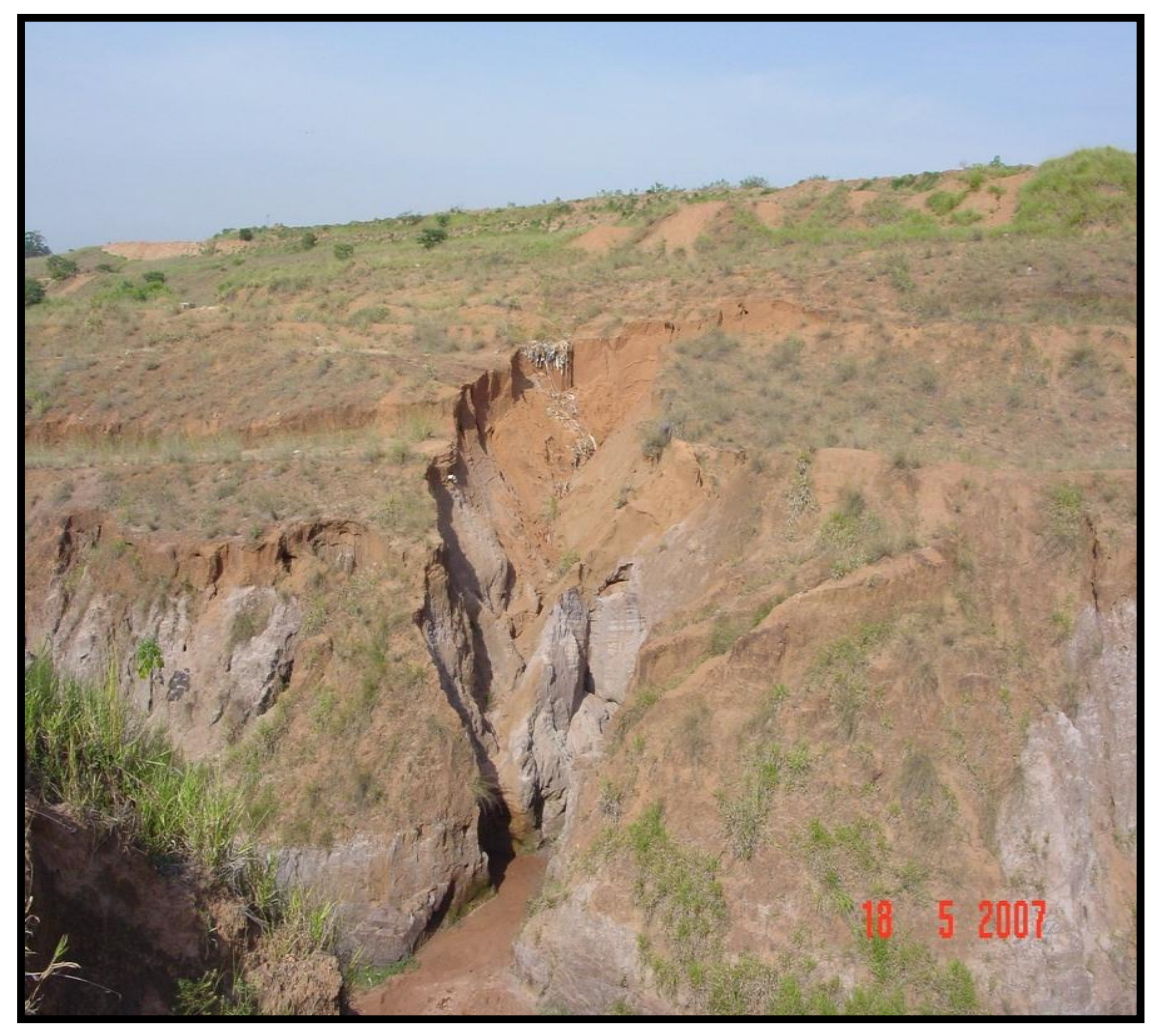

Figura 3 - Morfologia de sulcos e voçorocas (São Pedro - SP) 
A compreensão da infiltração de água no solo abrange o entendimento e análise do ciclo hidrológico, pois em função de quanto o solo é capaz de reter liquido, é possível conhecer o tipo de escoamento que ocorrerá.

A movimentação das águas sobre e/ou sob a superfície, possui papel central na formação e evolução dos movimentos do maciço terroso. Os estudos sobre escoamentos das águas em diferentes trajetórias são fundamentais ao entendimento da quantificação da erosão dos solos, conforme atesta Coelho Netto (1994).

\subsubsection{Fatores intervenientes}

Para se analisar os fatores que interferem na erosão de um solo deve-se partir da sua gênese para se conhecer o tipo de sedimento formado e suas vulnerabilidades. Dessa forma todos os componentes do ciclo sedimentológico (clima, vegetação, topografia) entre outras condições, contribuirão para o entendimento das propriedades do solo a ser erodido.

IBGE/SEPLAN-MS (1989), apud Silveira (2002), propõe uma subdivisão nos fatores que interferem no processo erosivo. Resumem-se em fatores naturais e antrópicos, extrínsecos e interdependentes:

- Fatores imutáveis a curto espaço de tempo - relevo, solo e clima;

- Fatores mutáveis a curto espaço de tempo - cobertura vegetal, uso do solo, manejo e práticas conservacionistas e estrutura fundiária.

A topografia é um fator natural que determina velocidade dos processos erosivos, sendo que maiores velocidades de erosão podem ser mais esperadas em relevos acidentados, como taludes inclinados, do que em relevos suaves, como colinas amplas, pois declividades mais acentuadas favorecem a concentração e maiores velocidades de escoamento das águas, aumentando sua capacidade erosiva. A declividade tem tanto maior importância quanto maior for o trecho percorrido pela água que escoa, ou seja, quanto maior for o comprimento da encosta. Por isso, a influência da topografia na erosão é analisada pela ponderação de dois fatores: declividade e comprimento da encosta ou talude.

O tipo de solo deve ser analisado segundo suas características e sua interação com outros fatores. As propriedades que afetam a erosão são: granulometria, estrutura, condutividade hidráulica, teor de matéria orgânica; que quando combinadas conferem resistência à ação das águas. 
Fendrich (1988) discursa que, a cobertura vegetal influencia as taxas de escoamento superficial, visto que essa representa uma barreira física ao fluxo de água, considerando que sua rugosidade é considerável. Afirma também que, a vegetação é o fator que mais afeta a erosão do que qualquer outro fator físico individual. E adiciona que, como fator de influência nos fenômenos erosivos, as seguintes considerações podem ser feitas em relação à cobertura vegetal:

- a porcentagem de solo coberto com vegetação é inversamente proporcional à ocorrência de erosões.

- a proteção oferecida pelas plantas é dividida em três níveis: da copada (folhas, ramos, etc.), da superfície do solo (troncos e raízes afloradas) e do interior do solo (raízes).

- a vegetação acrescenta a quantidade de matéria orgânica do solo, aumentando sua porosidade e, como resultado, a penetração e retenção de água são facilitadas.

- quando as raízes morrem, a penetração de água aumenta devido às galerias deixadas por elas.

- o funcionamento das plantas é semelhante ao de uma bomba, ou seja, elas retiram água do solo e a eliminam na atmosfera através da transpiração.

- as sombras das plantas evitam a queima da matéria orgânica com a diminuição da insolação.

A chuva pode provocar uma aceleração maior ou menor da erosão, dependendo também da forma como cai: sua distribuição mais ou menos regular, no tempo e no espaço, e sua intensidade. Por exemplo, chuvas torrenciais ou pancadas de chuvas intensas, como trombas d'água, durante os períodos chuvosos (verão, no território paulista), constituem a forma mais agressiva de impacto da água no solo. Durante estes eventos a aceleração da erosão é máxima, e é nestas ocasiões que ravinas e boçorocas ativas avançam rapidamente.

Como visto, as chuvas intensas possuem elevada erosividade, devendo ser consideradas nos estudos envolvendo os efeitos dinâmicos contribuídos por estas, como:

- os impactos das gotas favorecem a destacabilidade do solo desnudo (Figura 4).

- o escoamento superficial direto desagrega as partículas do solo devido à chuva efetiva, quando o solo já atingiu sua capacidade de infiltração. 
- o escoamento subterrâneo ocasiona o desmonte de maciços com a desagregabilidade do subsolo.

- a chuva apresenta capacidade transportadora sobre solos destacados e desagregados.

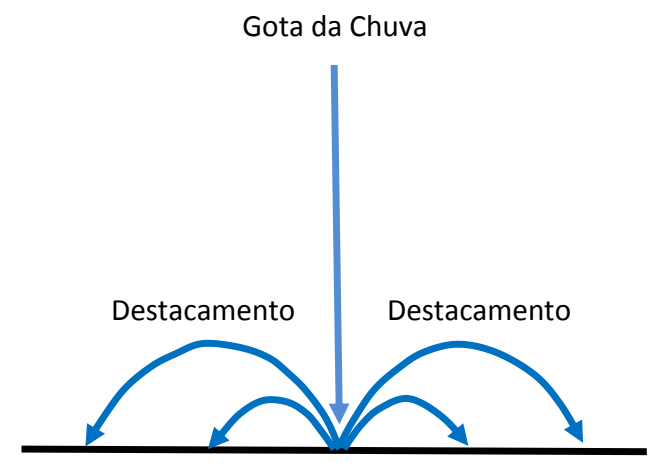

Figura 4 - Impacto e efeito da gota da chuva

Em certas regiões (locais com predomínio de queimadas ou áreas afetadas pela emissão de gases industriais), a depender do tipo de solo e seus minerais, a constituição da água da chuva pode interferir diretamente no processo erosivo. Isso porque, composição química da água intersticial do solo pode modificar a sua sucção osmótica e, a depender da composição do fluído que adentra o maciço e o tipo deste último, pode existir também uma mudança na sucção matricial do solo, (Hernandez Moncada, 2004; Lafayette et al., 2005).

Futai et al. (2005) também observou a interferência da sucção na evolução de uma voçoroca, quando entendeu que, através de experimentos e simulações numéricas, o processo de voçorocamento é causado por escorregamentos rasos devido a uma diminuição da sucção do solo.

Vários são os fatores que contribuem na gênese das erosões e, portanto, devem estar associados. Mas ainda é concenso que a ação antrópica é a principal deflagladora da erosão, por meio dos desmatamentos, alterações na paisagem, uso e ocupação desordenados do solo.

Trabalhos como os de Gruber et al. (1995), Mio et al. (1995), Zuquette et al. (1995), Carvalho (2005), Silva et al. (2005) e Guimarães (2008) evidenciam aspectos relevantes ou um conjunto destes como desencadeadores dos processos. 


\subsection{SOLOS NÃO-SATURADOS}

O estudo dos solos não-saturados mostra que as definições e modelos clássicos, desenvolvidos pela Mecânica dos Solos, foram concebidos com a tendência de considerá-los em situações extremas de saturação. Abordagem esta que exibe um reflexo das condições ambientais das regiões de climas temperados e das necessidades técnicas donde a Ciência primeiro evoluiu.

O fato de as maiores ocorrências de solos não-saturados darem-se em regiões menos desenvolvidas e prósperas do globo terrestre, associado às dificuldades teóricas e práticas do comportamento destes solos, contribuiu em muito para retardar o desenvolvimento de teorias dessa classe de solos (Presa, 1988; Vilar, 2000; Röhm, 2004 e Vilar, 2004).

A condição do solo não-saturado, apesar de ser amplamente encontrada na Engenharia Geotécnica, sobretudo nas zonas tropicais e semi-áridas, só recentemente recebeu um tratamento aprofundado, analisando-se as características de resistência e deformação com base em técnicas que permitem conhecer a sucção.

Embora a condição de saturação se mostre a mais crítica numa diversidade de situações, nem sempre esta situação extrema está associada ao pior efeito do comportamento do solo. Além disto, admitir que o solo exposto às condições ambientais naturais sempre experimentará um estado de saturação já não é aceito. Por exemplo, em regiões de climas áridos e semi-áridos a saturação nunca ocorre (Alonso et al., 1987 apud Röhm, 2004).

Jucá (1990) diz que, em regiões com clima tropical, assim como em locais onde o clima predominante seja árido ou semi-árido, grande parte dos problemas geotécnicos está associada ao comportamento de solos parcialmente saturados ou, não saturados. Nestas localidades, a grande maioria dos solos, em função das suas características físico-químicas originárias do processo de formação, apresenta alta porosidade e grande sensibilidade das ligações cimentícias em presença de água (Paixão \& Camapum de Carvalho, 1994 apud Camapum de Carvalho, 2006).

Períodos bem definidos de chuvas e estiagem (evaporação > infiltração) são fenômenos que levam a variação no teor de umidade do solo e nível do lençol freático alterando, por fim, o comportamento mecânico do maciço. Porém, estes períodos não ocorrem de maneira uniforme ao longo dos anos, fazendo com que o solo atinja valores de sucção diferentes, a depender de seu histórico de umedecimento e secagem (Beneveli, 2004). 


\subsubsection{Generalidades}

A condição não saturada se deve à ocorrência de ar nos vazios em quantidade que varia de acordo com o grau de saturação. Inicialmente, o comportamento dos solos foi justificado pela interação das suas três fases contituintes (sólida, líquida e gasosa). O líquido e os gases contidos nos poros se movimentam pela influência de forças potenciais que agem sobre o sólido e os fluídos (Vilar, 2000; Röhm, 1992).

Fredlund (1993) menciona que a diferença básica entre os solos não-saturados e os solos saturados é que os primeiros se caracterizam por ter uma pressão negativa da água nos poros que, acontece quando os solos se situam acima do nível d'água. Diz ainda que, um solo nãosaturado apresenta mais que duas fases e a poro-pressão ou a pressão exercida pela água nos poros é negativa em relação à pressão do ar. Desta forma, qualquer solo próximo à superfície terrestre, localizado em ambiente relativamente seco, estará sujeito às pressões na água negativas e uma possível insaturação.

O detalhamento da estrutura dos solos e conhecimento da influência de cada fase isoladamente permitiu que ao sistema trifásico fosse adicionada mais uma fase. $\mathrm{O}$ solo passou a ser considerado uma mistura de quatro fases com grau de saturação inferior a um: duas fases em equilíbrio (partículas de solo e película contráctil) e duas fases que fluem (ar e água), conforme ilustrado na Figura 5, (Bueno \& Vilar, 1979; Fredlund, 1993; Farias, 2004).

A película contráctil se forma devido à diferença de pressões atuantes no contato das fases líquida e gasosa. Ocorre um movimento das moléculas de água superficiais para o interior da massa líquida, como forma de equilibrar estas forças. Dessa forma a interface água-ar se traciona formando uma concavidade para o ar (Figura 6). A diferença de pressões $\left(\Delta_{U}\right)$ é função da tensão de superfície $\left(T_{S}\right)$ e do raio de curvatura da membrana contráctil $\left(R_{S}\right)$, como (1).

$$
\begin{gathered}
\Delta_{U}=\frac{T_{S}}{R_{S}} \\
2 \pi \cdot r \cdot T_{S} \cdot \cos \alpha=\pi \cdot r^{2} \cdot h_{c} \cdot \gamma_{w}
\end{gathered}
$$

Exemplo do efeito capilar pode ser visto quando um tubo é colocado em contato com a superfície livre da água, esta sobe pelo tubo até atingir uma posição de equilíbrio. A subida da água é resultante do contato vidro-água-ar e da tensão superficial da água. O equilíbrio 
equivale à máxima altura atingida pela coluna d'água no tubo $\left(h_{c}\right)$ e pode ser determinada igualando-se o peso da água no tubo com a resultante da tensão superficial que a mantém nessa posição (acima do nível da água livre). Sendo $\rho_{w}$ (massa específica da água); $\alpha$ (ângulo de interseção da membrana com as paredes do tubo e depende do material) (Pinto, 1991).

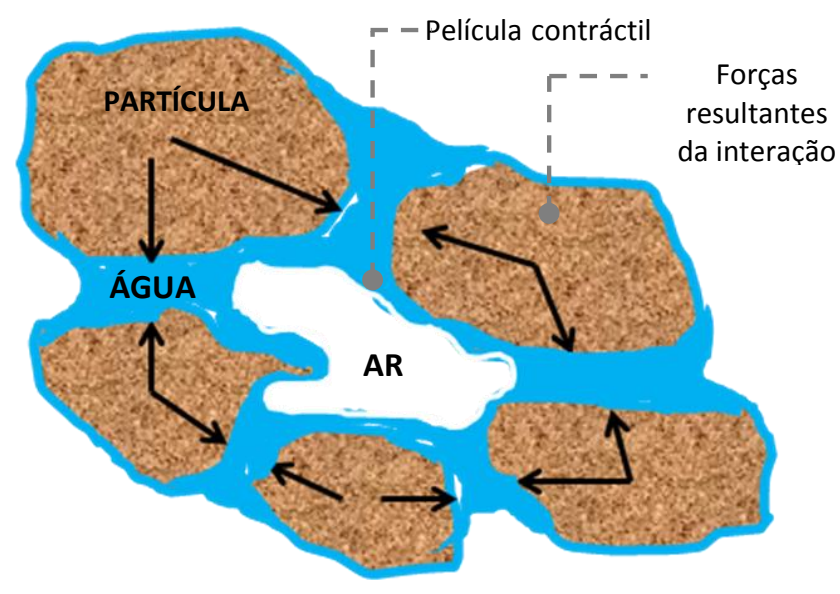

Figura 5 - Elemento de solo não saturado (Bueno \& Vilar, 1979)
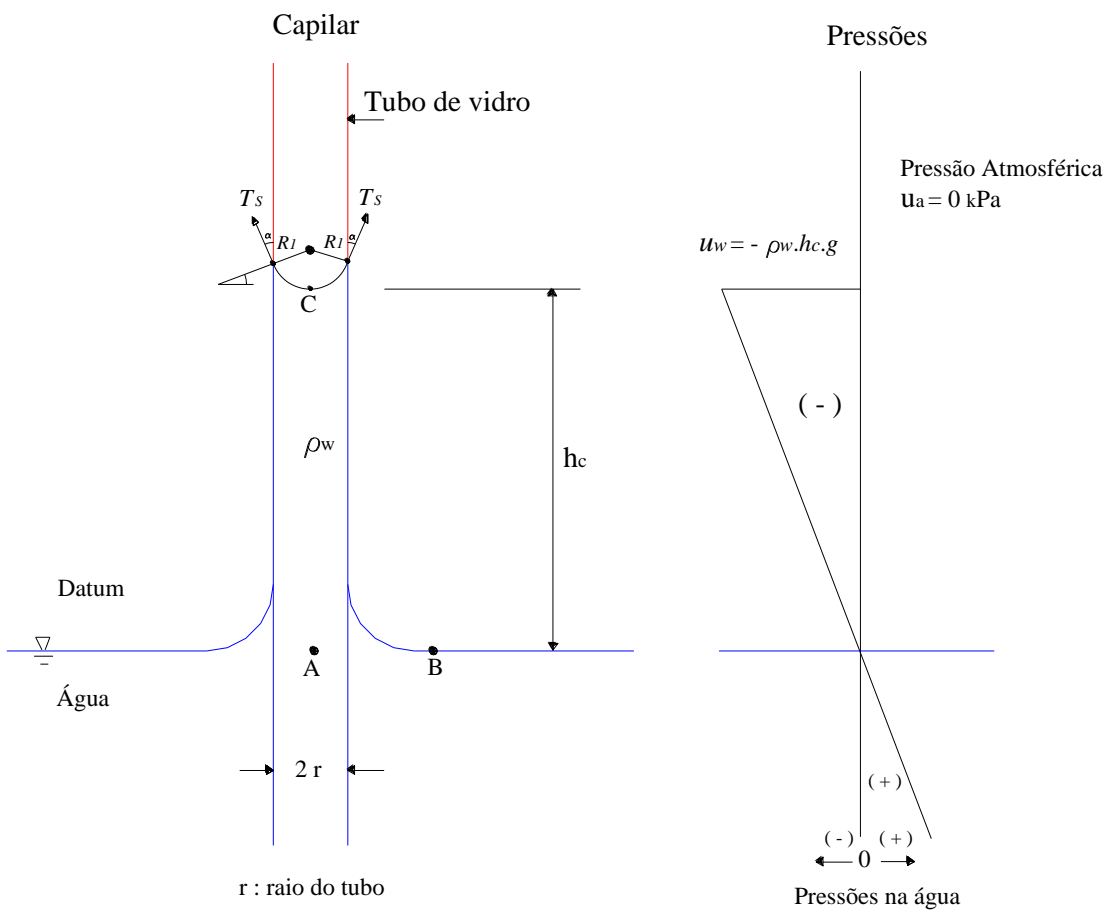

Figura 6 - Fenômeno da Capilaridade (Fredlund, 1994) 


\subsubsection{Sistema solo não saturado - atmosfera}

Sob o ponto de vista hidrológico, o solo pode ser entendido como um reservatório de água, cujo volume varia com o tempo em função de diversos fatores. A quantidade de água armazenada nesse reservatório pode ser determinada computando-se todos os fluxos de entrada e saída de água do sistema (Borma, 2004).

O mesmo autor citando Wilson (1990) e Wilson et al.(1994), diz que o fluxo de água e a umidade entre a superfície do solo e a atmosfera é um processo complexo no qual três fatores são dominantes, mas não funcionam como variáveis independentes e sim como um sistema fortemente acoplado. O primeiro fator é o suprimento e demanda de água impostos pelas condições atmosféricas, tais como a precipitação total, a radiação líquida, a velocidade do vento, a umidade relativa do ar, a pressão atmosférica e a temperatura do ar.

O segundo fator é a habilidade do solo em transmitir água, função da condutividade hidráulica e das características de armazenamento e retenção de água. O último fator está relacionado à influência da vegetação. $O$ tipo e densidade da vegetação afetam a evaporação por meio do consumo de água através das raízes e afetam também as taxas de runoff e retenção do escoamento superficial.

Porém, a dinâmica da água no solo e na atmosfera e todos seus fenômenos condicionantes (evapotranspiração, evaporação e infiltração) ganham importância na medida em que a sucção interfere no comportamento do solo através de mecanismos como a velocidade de absorção, a capacidade de retenção e resistência mecânica (Santos, 2004).

Rodrigues (2007) explica que, em termos práticos, ao considerar a retenção da água acima do nível freático no sistema água-solo-vegetação a existência da sucção é facilmente compreendida. Se a água contida nesse sistema dependesse somente das forças gravitacionais, então o nível freático determinaria um limite físico para a presença de água no solo.

Neste caso, o solo estaria saturado (fase sólida + fase líquida) em qualquer ponto abaixo do nível freático e em estado seco (fase sólida + fase gasosa) em qualquer ponto sobre a superfície freática. No entanto, a situação real da água no solo mostra que mesmo com a atuação das forças gravitacionais é possível encontrar água armazenada acima do nível freático.

Os principais efeitos da infiltração em um solo não saturado são: a diminuição da sucção atuante no meio e de sua contribuição para a coesão (coesão aparente), o aumento da condutividade hidráulica do solo, e o aumento do peso específico do solo. 
Tendo em vista essas relações, Oliveira (2004) afirma que, em geral, a previsão do comportamento dos solos não-saturados exige a compreensão dos fluxos de água entre solo e a atmosfera, sendo que inúmeros trabalhos retratam a importância dessa análise nesse tipo de solo, como os de: Reichardt,1993; Queiroz, 1999; Medeiros, 2001; Naime,2001; Netto, 2004; Engler, 2004; Gerccovich, 2004; Palma, 2004; Cavalhero, 2005; Burgos, 2005; Cardoso Júnior, 2006; Mota, 2007; Dourado Neto, 2007.

\subsubsection{Potencial da água no solo}

A base física dos conceitos isotérmicos dos processos relativos às interações entre a água e o solo constitui-se dos conhecimentos inicialmente publicados por Buckingham (1907), citado por Machado (1998), que realizou estudos sobre o movimento da água no solo e definiu um potencial capilar a um dado teor de umidade e a uma temperatura e massa específica do solo, como sendo o trabalho reversível, por unidade de massa, necessário para transferir água de um solo para um reservatório com água pura.

Segundo Vilar (2000), a ocorrência de água em um solo não saturado, pode ser descrita recorrendo-se à quantificação do estado de energia em que a água se encontra. Reconhecemse, classicamente, duas formas de energia: a potencial e a cinética. Nos solos, considerando-se a reduzida velocidade de fluxo nas situações corriqueiras, a energia cinética é usualmente desprezada. A energia potencial, ou simplesmente, potencial da água, decorre da interação da água com campos de força, como por exemplo, o gravitacional.

De acordo com Machado (1998), para que se defina o potencial de água no solo, devese antes se estabelecer um estado de referência padrão, a partir do qual as medidas da água no solo possam ser retiradas sem ambigüidades. Levando em conta a componente de água no solo, define-se o estado de referência padrão como sendo uma solução livre da influência da matriz do solo, pura (sem a presença de solutos), num dado referencial de posição, à uma dada temperatura e submetida à pressão atmosférica padrão.

Assim sendo, outras definições podem ser expostas como as realizadas por Richards (1928); Iwata et al. (1988); Brady (1989) apud Pereira (2004); e Röhm (2004), respectivamente:

- “É a mínima energia por unidade de massa, necessária para deslocar um volume infinitesimal de água de um estado de referência arbitrado, até outro ponto da fase líquida que permaneça em repouso." 
- "O potencial total da água no solo representa o trabalho útil que deve ser realizado em uma quantidade infinitesimal de água pura, para transportá-la, em condições reversível e isotermicamente, desde um reservatório sob condições padronizadas (isto é, água pura, em uma determinada cota e sujeita à pressão atmosférica) - ponto A - até a água no solo, no ponto considerado - ponto B - e sujeita à pressão neste ponto $\left(u_{B}\right)$ ”, como no esquema da Figura 7.

- "O potencial total da água no solo é a soma dos potenciais capilar e gravitacional."

- Pode ser representado pela seguinte expressão:

$$
\phi=\phi_{T}+\phi_{P}+\phi_{M}+\phi_{O}+\phi_{Y K}
$$

Onde: $\Phi=$ potencial total da água no solo $\quad \Phi_{M}=$ componente matricial

$\Phi_{\mathrm{T}}=$ componente de temperatura $\Phi_{\mathrm{O}}=$ componente osmótico

$\Phi_{\mathrm{P}}=$ componente de pressão $\quad \Phi_{\mathrm{YK}}=$ outros componentes

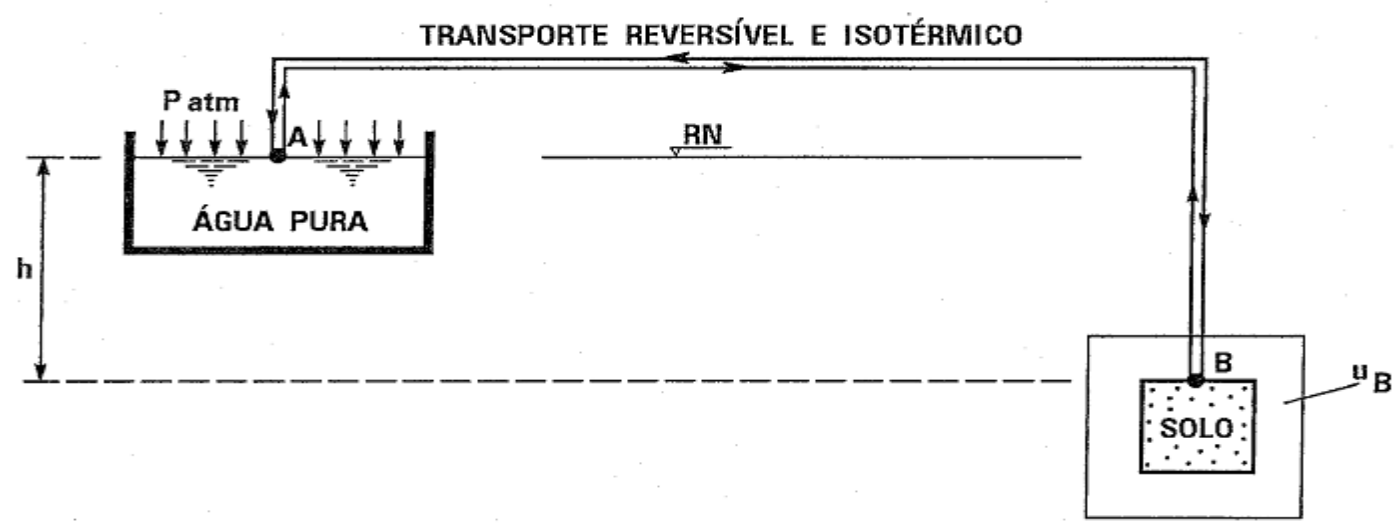

Figura 7 - Ilustração do conceito do potencial total da água no solo (Vilar, 2000)

Consoante Vilar (2000), os componentes do potencial total são o potencial osmótico, o potencial gravitacional, o potencial matricial e o potencial pneumático, ou seja, são parcelas de energia que contribuem efetivamente para o potencial de água no solo. Outros componentes podem ser incluídos, como, o potencial de consolidação, porém são de importância menor no comportamento geotécnico de solos não saturados. Cada potencial pode ser sucintamente definido como: 
- potencial osmótico ou de soluto reflete a influência da presença de solutos na água do solo. É função da diferença de composição entre a água do solo (presença de sais minerais e substâncias orgânicas) e a água pura.

- potencial gravitacional traduz a componente de posição, isto é, o fato de que a água no solo esteja em cota diferente da água do reservatório padrão. Existe independente da condição do solo, estando relacionado apenas com o campo gravitacional terrestre, não exercendo nenhuma influência sobre a sucção.

- potencial matricial da água do solo é um potencial de pressão, que ocorre devido o efeito combinado da ação das forças capilares e de adsorção, que surgem da interação entre a água e as partículas minerais ou a matriz que compõe o solo (Hillel, 1971 apud Pereira, 2004).

A interação solo-água pode também ser quantificada a partir da avidez que um solo não saturado tem por água, por exemplo, se colocado em contacto com um reservatório de água pura livre, o solo absorve água, pelo fato de exercer uma pressão de sucção sobre a água. Se uma pressão de sucção é aplicada sobre o reservatório, de sorte a impedir que o solo absorva água (ou seja, que não ocorra fluxo), tem-se uma pressão na água livre equivalente à pressão de sucção na água do solo.

Essa pressão se constitui noutra forma de representar o estado de energia da água em um solo não saturado e ela é governada por duas componentes: a matricial e a osmótica (Vilar, 2000).

\subsubsection{Tensão de Sucção}

O desenvolvimento teórico-conceitual de sucção em solos data do início do século XX e está relacionado com princípios da Termodinâmica utilizados pela Física dos solos. O termo termodinâmico "energia-livre" era comumente empregado na abordagem da umidade do solo e, portanto, na sucção (Fredlund, 1993).

Em 1935, Schofield aplicou o termo "sucção do solo" para representar a deficiência de tensão na água dos poros de alguns solos saturados ou não saturados (Barrera, 2002 apud Farias, 2004). Já, em meados da última década, verificou-se um crescente interesse no estudo dos solos na-saturados em nível mundial, com ênfase para o desenvolvimento de técnicas laboratoriais e de campo que objetivam a medição das tensões de sucção. 
O solo não saturado por ter uma pressão negativa na água intersticial, apresenta a sucção $\left(S=u_{a}-u_{w}\right)$ como a diferença entre as pressões no ar $\left(u_{a}\right)$, considerada na maioria dos casos como a pressão atmosférica $\left(P_{a t m}\right)$, e na água $\left(u_{w}\right)$ que, em princípio, decorre das interações existentes entre a água e o ar (efeito de capilaridade) e entre a água e as partículas sólidas (forças superficiais de origem eletro-química), responsáveis pelo aparecimento da sucção matricial, e de fenômenos osmóticos, devido à presença de solutos na água do solo, responsável pela sucção osmótica (Wolle, 1988; Vilar, 2000).

Outros termos têm sido utilizados para descrever a energia de retenção de água pelo solo, como por exemplo, "pressão de sucção" e "pressão neutra negativa" que indicam, respectivamente, a tendência do solo em succionar a água livre com a qual está em contato, e o fato de que, estando o ar à pressão atmosférica, a pressão na água será negativa. Dessa forma, a pressão de sucção equivale à pressão neutra a menos do sinal algébrico $\left(P_{s u c}=-u\right)$, e deve ser usada para avaliar as tensões efetivas nos solos não-saturados.

Segundo Marinho (1997), pode ser definida como uma pressão isotrópica da água intersticial que faz com que o sistema água-solo absorva ou perca água, dependendo das condições ambientais, aumentando ou diminuindo o seu grau de saturação. Em outras palavras, pode ser interpretada como a avidez que um meio poroso não saturado tem pela água, resultante das forças capilares, de adsorção e da concentração de solutos.

Ainda, a tensão de sucção pode ser equiparada à energia necessária ao rompimento da adesão "água - superfícies hidrofílicas" causada pelas ligações de hidrogênio e interações bipolares. Essa tensão negativa se opõe à saída de água dos materiais e equivale a um acréscimo de pressão útil para movimentar um volume de água unitário do arcabouço sólido de um material (Fumió, 2004).

Quando quantificada em função da umidade relativa é chamada sucção total, cujos componentes de maior interesse são a sucção matricial e a sucção osmótica. A primeira está associada ao fenômeno da capilaridade, ao tipo de partículas e seu arranjo estrutural, ao passo que o componente osmótico relaciona-se à presença de íons e outros solutos na água intersticial ou a concentração química da água (Fredlund, 1993; Farias 2004; Hernandez Moncada, 2004).

Pereira (2004) afirma que as sucções matricial e osmótica são grandezas positivas, enquanto os correspondentes potenciais são negativos. Isto pode ser observado na Figura 8 que ilustra os conceitos de sucção total, matricial e osmótica, considerando que esteja atuando 
a pressão atmosférica. $\mathrm{O}$ reservatório de água pura livre constitui-se num referencial para a medida de energia, ao qual é atribuído o valor zero. Como a água flui espontaneamente do reservatório para o solo, resulta que o potencial no solo deve ser inferior ao padrão, por conseguinte, negativo.

A importância da sucção também se revela no que concerne às variações de volume do maciço. Pois como se trata de uma força de atração intergranular, a tendência é impedir variações de volume que ocorreriam a fim de propiciar ao material uma condição estrutural mais estável (Martins, 1997).

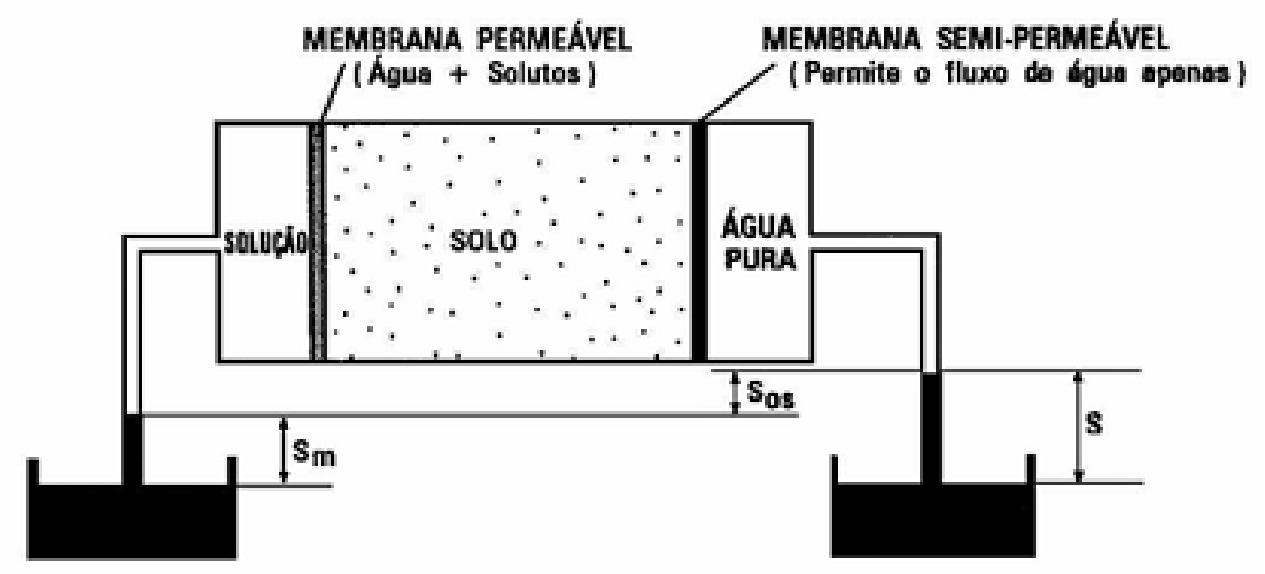

Figura 8 - Ilustração dos conceitos de sucção (Vilar, 2000)

Mesmo com destacada relevância, Porras Ortiz (2004) comenta que em muitas aplicações de engenharia estes fenômenos são ignorados, no entanto a estabilidade de maciços naturais, o transporte de grãos e materiais que podem deflagrar os processos erosivos em solos, e variações volumétricas de meios particulados são altamente dependentes das forças elétricas (como visto no trabalho de Saramago, 1997) e de capilaridade.

Segundo a literatura pesquisada, existem inúmeros equipamentos e ensaios laboratoriais e de campo para o estudo da tensão de sucção e, Fumió (2004) citando Reichardt (1985) comenta que os mais usuais são os funis de placa porosa e as câmaras de pressão, sendo estes e os demais descritos mais adiante. 


\subsubsection{Influência da sucção e do teor de umidade na erosão}

Para estudos dos condicionantes das feições erosivas e influência na erodibilidade dos solos, a sucção mátrica terá precípua consideração em detrimento da osmótica, pois como visto, o comportamento e deformação dos solos não - saturados é preponderantemente influenciado pela sucção matricial, restando à sucção osmótica um papel secundário.

A formação dos solos não-saturados em áreas de clima tropical faz com que ocorra intensa lixiviação dos finos no horizonte superficial, criando uma estrutura porosa e muito permeável, o que resulta normalmente em nível freático profundo com espessas camadas de solo não saturado (Lobo, 1997).

Acrescenta-se a este comportamento o efeito da cimentação pois confere ao material um aspecto de enrijecimento semelhante ao da sucção. A sucção pode ser eliminada pelo umedecimento do solo e a cimentação pode ser destruída por remoldagem. O aumento do teor de umidade também pode dissolver os agentes cimentantes, além de diminuir as tensões causando bruscas reduções de volume e colapso do solo.

Devido à permeabilidade dos solos residuais ser frequentemente elevada, a infiltração das águas de chuva exerce papel preponderante na instabilização dos maciços, uma vez que leva a um incremento dos esforços solicitantes e a uma redução dos parâmetros de resistência, principalmente no que se refere à redução da pressão de sucção e, consequentemente, da coesão aparente adicional (Abramento, 1988; Campos, 2002).

Torna-se importante conhecer as respostas do solo não-saturado diante das variações de sucção e do teor de umidade, apesar deste estudo ser considerado complexo devido a problemas associados a não linearidade de fluxos, a influência da temperatura, a permeabilidade em meios não-saturados e a histerese na relação sucção-umidade (Pereira, 2004).

Mesmo com essas restrições, é possível estimar aproximações do comportamento hidráulico dos solos não saturados através, por exemplo, do uso de correlações com a curva de retenção de água. Esta forma de análise permite conhecer parâmetros como a sucção, prevendo-se o comportamento do solo frente às situações em que a umidade do solo oscila significativamente. 


\subsection{ERODIBILIDADE DOS MATERIAIS INCONSOLIDADOS}

Entre as principais propriedades do solo que contribuem para uma maior ou menor resistência à ação erosiva das águas, ou seja, sua erodibilidade, a textura influi na capacidade de infiltração e absorção d'água, interferindo no potencial das chuvas no solo, e também na maior ou menor coesão entre as partículas (Oliveira, 1998).

Lin et al. (1999) apud Netto (2004) comenta que a estrutura do solo é fundamental na caracterização do comportamento hidráulico dos macroporos na região de fluxo, enquanto que a textura tem o principal impacto nas propriedades controladas pelos microporos. E conclui, citando Vaz (1997), que a determinação das partículas do solo é um parâmetro essencial na caracterização dos mesmos no que tange a qualidade do solo sob os aspectos da erosão.

Solos de textura arenosa são normalmente porosos, permitindo rápida infiltração das chuvas e dificultando o escoamento superficial; entretanto, como possuem baixa proporção de partículas argilosas, apresentam maior facilidade para a erosão, que se verifica mesmo em pequenas enxurradas.

Outra característica importante do solo, relacionada ao comportamento erosivo, é a sua espessura. Solos rasos são mais vulneráveis aos eventos chuvosos pois permitem rápida saturação dos horizontes superficiais, e por isso apresentam maior incidência de erosões. Os solos profundos apresentam maior capacidade de infiltração das águas pluviais, disponibilizando menor quantidade de água superficial e, portanto, são menos erodíveis (Oliveira, 1992).

Tais propriedades dos solos são largamente empregadas na determinação de sua suscetibilidade aos fenômenos erosivos, tanto suas características físicas, químicas e mineralógicas, como visto nos estudos de Ângulo (1984); Indraratna (1991); Amon (1994); Cavalieri (1994); Viana (2002).

\subsubsection{Generalidades}

Para firmar o conceito de erodibilidade deve-se considerar que, além das variáveis externas, os processos erosivos devem ser avaliados mediante estudo dos fatores intrínsecos dos quais o principal é o tipo de solo. Segundo o DAEE (1990), o tipo de solo determina a vulnerabilidade dos terrenos à erosão, e estabelece a maior ou menor facilidade dos solos serem corroídos, fixados os demais fatores antes mencionados. 
Silveira (2002) define erodibilidade como a facilidade que o solo apresenta em sofrer desagregação de suas partículas constituintes e posterior transporte. Sendo que a facilidade com que as partículas se desprendem está intimamente relacionada com as forças de atração existentes no solo e a transportabilidade relaciona-se às suas características físicas (tamanho e formato dos grãos).

Pejon (1992) qualifica a destacabilidade e trasportabilidade de solos finos e grossos quando discorre que, para o primeiro tipo de maciço o despreendimento das partículas é mais difícil devido às forças de atração que caracterizam o material, mas uma vez destacadas, o transporte é realizado sem esforços já que as partículas mantêm-se suspensas. No caso dos solos grossos, dificilmente existem forças de coesão, no máximo uma coesão aparente que não obsta a destacabilidade dos grãos, porém o aumento destes dificulta seu transporte.

Além dos fatores intrínsecos do solo (natureza química e física), existem propriedades in situ que interferem na erodibilidade, como a umidade e as condições de infiltração de água. Quanto maior for a capacidade do solo absorver água, menor será o escoamento superficial e menor a erosão; por outro lado, quanto maior a umidade do solo, mais cedo o estado de saturação total do solo será atingido, aumentando o escoamento superficial (Pejon, 1992).

Vilar (1993) afirma que nos solos com alguma coesão se observa que o destacamento pode se dar através de partículas individuais. Porém há uma predominância de remoção de agregados de partículas, cujos tamanhos dependem da fração fina presente no solo. Citando Swanson et al.,1965 e Young 1980, diz que a remoção se dá segundo partículas individuais quando se tratam de solos não coesivos.

Young (1980), apud Vilar (1993) conclui que o processo erosivo é seletivo, com as partículas do tamanho dos siltes sendo erodidas com mais facilidade do que as argilas ou as areias e, dependendo da fração fina, o tamanho das partículas erodidas variará.

Resumidamente, a erodibilidade depende, principalmente, das características a seguir:

- textura

- medida e formato dos grãos do solo

- estrutura

- permeabilidade e infiltrabilidade

- coesão 
Alguns autores propuseram calcular o índice de erodibilidade que, a depender dos limites de seu intervalo, classifica os solos em não erodíveis até eminentemente erodíveis (Nogami \& Villibor, 1979; Pejon 1992; Philipponat, 1973 apud Vilar, 2003).

\subsubsection{Suscetibilidade dos solos argilosos e arenosos}

Os solos argilosos podem ser constituídos por argilominerais mais ou menos instáveis de acordo com suas propriedades físicas e químicas. Um comportamento erosivo destes solos pode ser condicionado pela presença da fração argila, independentemente da ação da chuva, conforme Pereira (2004).

Segundo Pereira (2004), os ciclos de umedecimento e secagem, bem como variações de temperatura ensejam a expansão e a retração de argilominerais presentes em certos solos, como os de natureza saprolítica, culminando com o destacamento dessas partículas do maciço.

Oliveira (1992) destaca a importância de conhecer os minerais constituintes dum solo para saber se são facilmente intemperizáveis, já que essa característica diz respeito à presença de minerais primários poucos ou medianamente resistentes à decomposição que são instáveis em relação a outros. A depender do mineral encontrado, pode-se ter estabilidade sob ação de condições tropicais a subtropicais, úmidas a subúmidas.

Segundo a mesma referência, a composição qualitativa e quantitativa do conjunto de espécies minerais integrantes do horizonte ou camada são demonstrativas do estágio de intemperização mais avançado ou menos avançado do mineral presente.

É fato que, os solos encontrados em regiões tropicais apresentam peculiaridades do ponto de vista do seu comportamento mecânico e hidráulico. Nestes solos, a importância do tipo e da quantidade do material encontrada na fração argila é muito pronunciada, visto que tal material muitas vezes governa seu comportamento (Silveira,2002).

O modo como se arranjam as partículas do solo também influi na capacidade de infiltração e absorção da água da chuva, e na capacidade de arraste de partículas do solo. A permeabilidade determina a maior ou menor capacidade de infiltração das águas da chuva, estando diretamente relacionada com a porosidade do solo (Oliveira, 1998).

Em geral, os solos arenosos são mais permeáveis que os solos argilosos, por serem mais porosos. Entretanto, em alguns casos, dependendo da estrutura do solo, solos argilosos podem se apresentar altamente porosos e até mais permeáveis que solos arenosos. 


\subsubsection{Metodologias para determinação}

Para medir a erodibilidade dos solos, muitas propostas foram concebidas ao longo do estudo da problemática. Bastos (1997) revela que os conceitos mais difundidos na quantificação da erodibilidade vêm do meio agronômico e da hidráulica de canais.

No primeiro, segundo ele, a erodibilidade é medida por parâmetros empíricos obtidos de trechos experimentais com o emprego de simuladores de chuva, aplicados em modelos de previsão de perda de solo. Na hidráulica de canais, conceitos físicos como tensão cisalhante crítica mais se aproximam à geomecânica, entretanto a erodibilidade também advém de ensaios específicos em modelos hidráulicos, como observado em trabalhos como os de: Tãvora (1985); Silva (1986); Rufino (1986); Carvalho (1997).

Não obstante, Bastos (1997) ainda afirma que, a Geotecnia têm se restringido a obtenção de índices baseados em variados experimentos, como o ensaio de Inderbitzen, a metodologia LNEC e a metodologia MCT. Outros diversos modelos também foram propostos para mensurar a erodibilidade, desde os matemáticos, como os citados por Alcântara (1997), o modelo proposto por Vilar (1987) e o modelo WEPP de predição de erosão, desenvolvido nos EUA, (Lane \& Nearing, 1989 apud Pereira, 1994), até os que se utilizam de elemento radioativo como o trabalho de Correchel (2003).

Pode ser avaliada de forma direta, por meio de ensaios específicos ou ainda por meio de ensaios indiretos, tais como os realizados durante a caracterização física, química e mineralógica, muito comuns em estudos geotécnicos.

Bryan (1969) e Denardin (1990) revelam que inúmeros índices, baseados em parâmetros do solo determinados em análises laboratoriais de rotina, têm sido usados para avaliar a susceptibilidade relativa dos solos à erosão. Como exemplos desses trabalhos, o segundo autor cita: Bennet, 1926; Middleton, 1930; Baver, 1933; Bouyoucos, 1935; Voznesensky \& Artsruui, 1940; O’Neal, 1952; Anderson, 1954; De Leenheer \& De Boodt, 1959; Bruce-Okine \& LAL, 1975.

O mesmo autor afirma que a maioria dos índices para determinar a erodibilidade, envolvem propriedades que governam os processos de agregação e estabilidade de agregados, retenção e transmissão de água e resistência ao impacto das gotas de chuva. Sendo que, estes índices representam uma medida relativa da desagregabilidade de um solo e podem não refletir, em condições naturais, o seu comportamento em resposta aos agentes erosivos. 
A compreensão do processo erosivo, muitas vezes, não leva em consideração a complexidade do mesmo, visto que a erodibilidade é função de um número grande de variáveis. Deste modo, não é possível explicar o comportamento do solo não saturado com base em um único fator ou na combinação de fatores simples, porque este é função das combinações e inter-relações de diversos fatores Fácio (1991), Silveira (2002), Pereira (2004).

Pejon (1992) assinala que existem vários métodos, quase todos obtidos de forma empírica, a fim de caracterizar a erodibilidade de maciços em taludes, por exemplo, e destaca trabalhos como os de Meireles (1967), Santos \& Castro (1966 e 1967), Philipponat (1973), Nascimento (1974), Nogami \& Villibor (1979) e Villibor et al. (1986). Porém, o autor analisando estes trabalhos verificou que eles identificaram holísticamente os materiais erodíveis, situando-se os melhores resultados em torno de $80 \%$.

Pejon (1992) também comenta que para a maioria dos autores por ele citados, os fatores de desagregabilidade e de absorção de água são muito importantes na análise da erodibilidade. E diz que o uso do índice de erodibilidade, proposto por Nogami \& Villibor (1979), usado em trabalhos de mapeamento geotécnico regional para predizer o comportamento dos materiais inconsolidados em taludes de corte, parece adequado, desde que sejam consideradas as seguintes observações:

- Evitar a coleta de amostras com grande quantidade de matéria orgânica, para impedir a variabilidade dos resultados nos ensaios, como visto no trabalho de Fernandes (2003).

- Coletar no mínimo três amostras em cada ponto para confirmação dos resultados, uma vez que se observaram variações, principalmente, no ensaio de perda de peso por imersão.

- Ter devida cautela com a retirada, transporte e manuseio das amostras, pois o ensaio de perda de peso por imersão é muito sensível à quebra da estrutura original do material amostrado e tem um peso elevado na determinação do índice de erodibilidade.

Camapum de Carvalho (2006) citou variados ensaios, suas metodologias e resultados na determinação da erodibilidade, a saber:

1) Ensaio de desagregação: consiste na introdução de amostras de solo em uma bandeja contendo água, observando-se as reações das amostras ao processo de submersão. 
Podendo-se, assim, prever o comportamento do solo quando inundado, e determinar a capacidade da água em desagregá-lo, como na Figura 9.
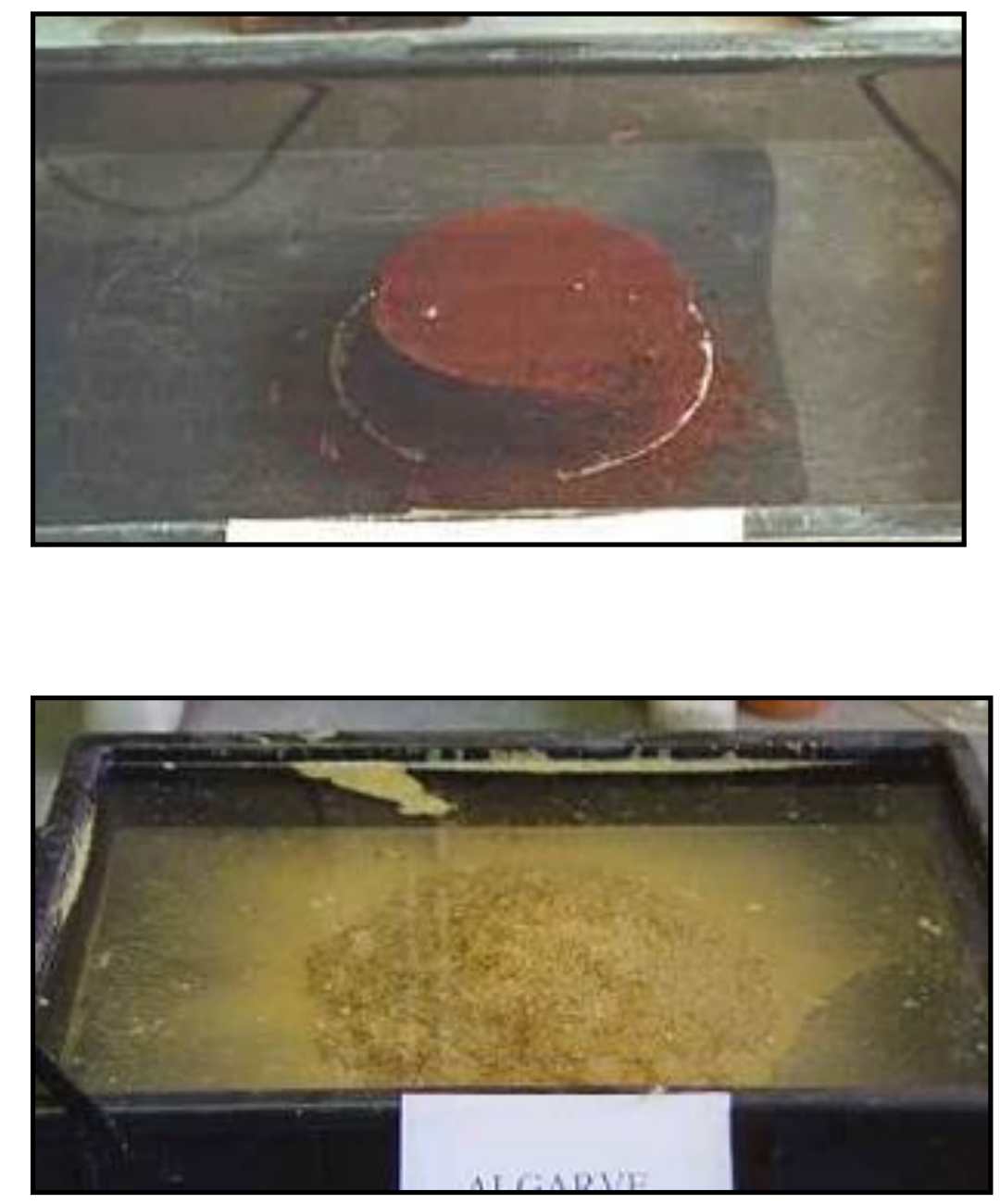

Figura 9 - Ensaio de desagregação por imersão (Bastos, 2004)

2) Ensaio de Inderbitzen (1961): simula um escoamento superficial sobre um corpo de prova, a uma dada vazão constante e inclinação variável do terreno, recolhendo-se e quantificando em tempos a perda de solo (Figura 10). A perda depende do tipo de solo, das condições do ensaio (fluxo e inclinação) e das condições da amostra (umidade, grau de saturação e orientação em relação ao fluxo de água). Por ser um ensaio simples e a fim de suprir algumas de suas limitações como por exemplo, não considerar o impacto da gota da chuva, alguns trabalhos propuseram 
modificações ao aparelho a fim de otimizar a mensuração da erodibilidade, como observado no estudo de Fácio (1991) e, o modelo proposto por Pereira et al. (2003). Fácio (1991) estabeleceu uma metodologia padrão a partir de uma série de ensaios variando os valores de vazão, declividade da rampa e tempo de duração do ensaio.

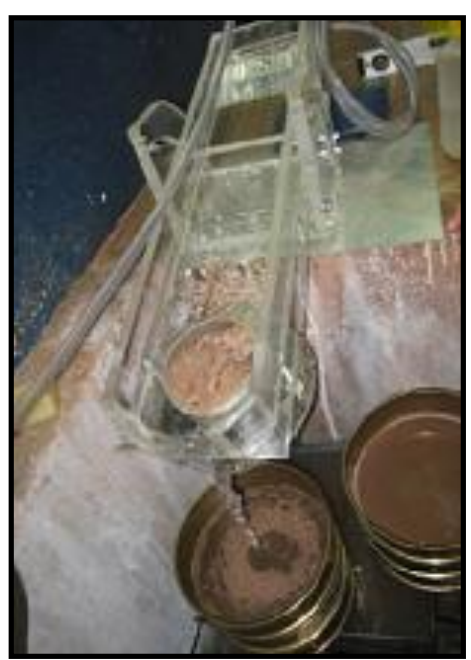

Figura 10 - Aparelho de Inderbitzen (Ide, 2009)

3) Ensaio do furo de Agulha (Pinhole Test) - consiste em fazer percolar água, sob uma certa carga hidráulica, através de um furo de $1 \mathrm{~mm}$ de diâmetro feito no centro do corpo de prova cilíndrico, na tentativa de simular o efeito de piping. A resistência à erosão é estimada pelo diâmetro final do furo, pela coloração da água que sai e pela vazão de percolação. No Brasil o ensaio se encontra normatizado pela $N B R$ 14114/98 da ABNT, como mostrado nas Figuras 11, 12 e 13.

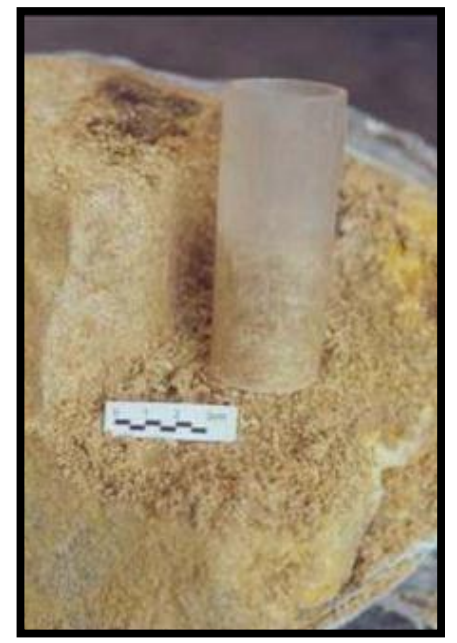

Figura 11 - Coleta de amostra (Camapum de Carvalho, 2006)

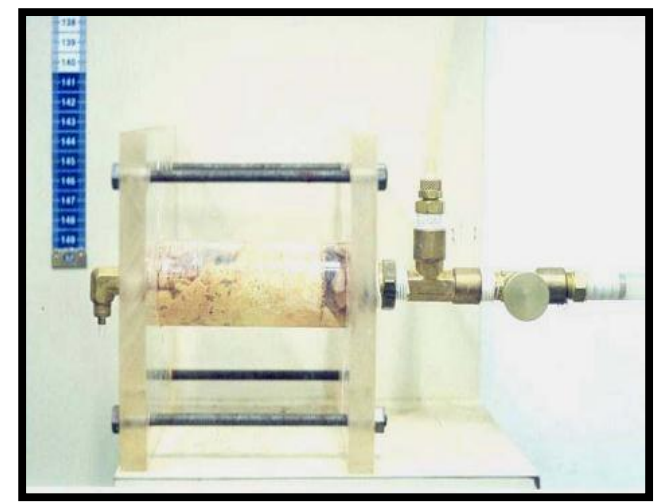

Figura 12 - Equipamento de Pinhole Test (Camapum de Carvalho, 2006) 


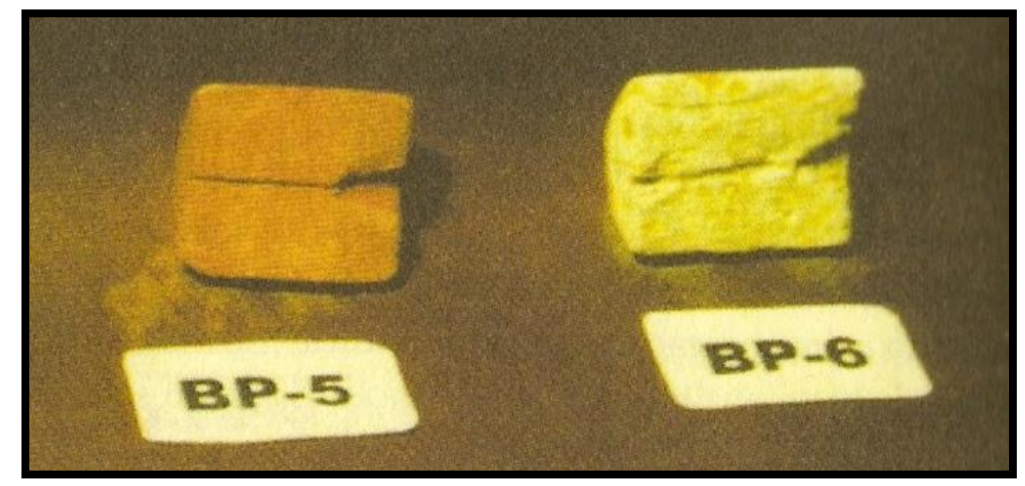

Figura 13 - Amostras após o ensaio de Pinhole (Camapum de Carvalho, 2006)

4) Ensaio de Crumb Test - é também conhecido como ensaio de dispersão rápida e objetiva classificar qualitativamente a reação de um porção de solo em relação à dispersão quando inundada em água. Resumidamente, consiste na colocação de uma porção de solo (cerca de $2 \mathrm{~g}$ ) em um béquer contendo $150 \mathrm{ml}$ de água destilada. Tal porção deve permanecer no recipiente por $1 \mathrm{~h}$ e decorrido este tempo, deve-se observar a capacidade de desprendimento de partículas ao redor da amostra imersa.

\subsubsection{Ensaio de Erodibilidade por Nogami \& Villibor (1979)}

A metodologia proposta se divide em duas etapas classificadas como simples, de fácil e rápida execução, bem como não dispendiosas por não necessitar de equipamentos sofisticados, conforme Pejon (1992).

As etapas são: o ensaio de absorção de água e o de perda de massa por imersão; as quais utilizam amostras indeformadas, através da moldagem de um corpo de prova com dimensões de $40 \mathrm{~mm}$ de diâmetro e $20 \mathrm{~mm}$ de altura em um cilindro de PVC rígido com a ponta biselada. A proposta clássica sugere que a amostra coletada seja mantida no cilindro para secagem ao ar e na sombra por um período de sete dias, ao menos (Figuras 14 e 15).

Pejon (1992) estabelece algumas vantagens desta metodologia pois: utiliza amostras indeformadas; considera o efeito de secagem; possibilita inferir propriedades de desagregabilidade e infiltração. 


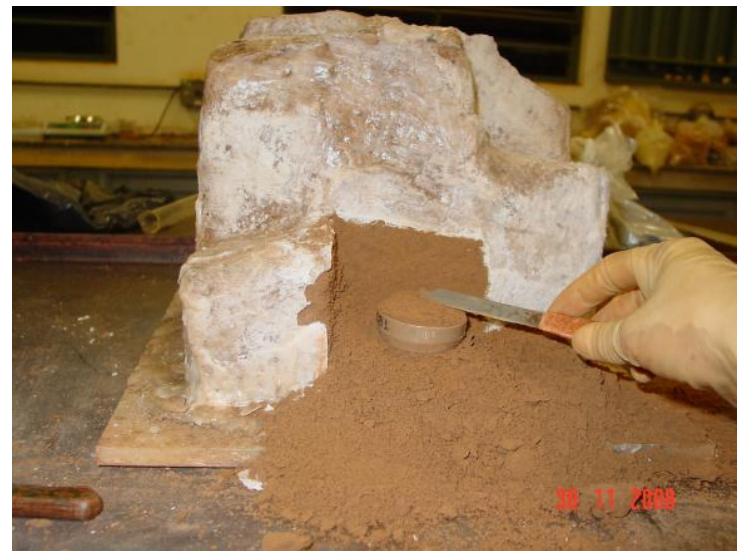

Figura 14 - Modelagem do corpo de prova

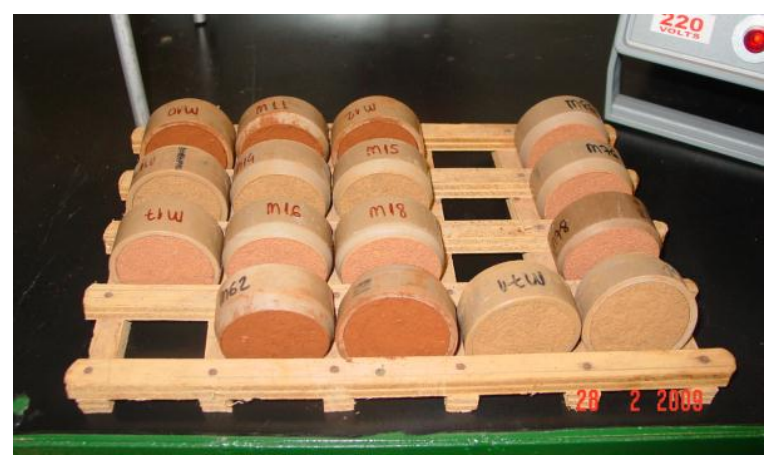

Figura 15 - Secagem ao ar

\subsubsection{Ensaio de Absorção de Água}

Para a realização deste ensaio, necessita-se de um equipamento que consiste de um recipiente cilíndrico (base), com as mesmas dimensões do cilindro de amostragem, conectado a um tubo de vidro horizontal graduado. O conjunto é preenchido com água e na porção superior do recipiente, adapta-se uma pedra porosa, que deve ser mantida saturada.

A amostra, ainda no cilindro de amostragem, deve ser pesada e logo depois colocada sobre a pedra porosa saturada, dando-se início neste momento à contagem de tempo e fazendo-se leituras de volume de água absorvida por intervalo de tempo, até que a água atinja o topo da amostra, como seguem nas Figuras 16 e 17.

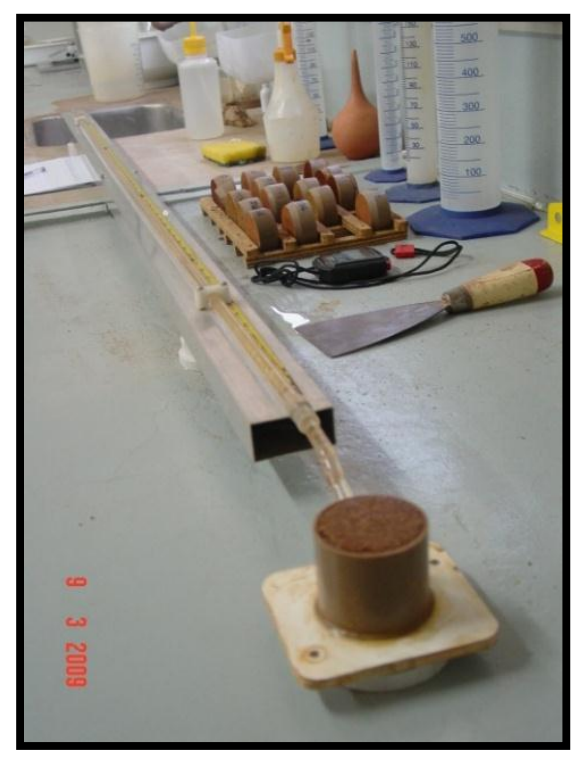

Figura 16 - Equipamento de Absorção de Água (EESC - USP) 


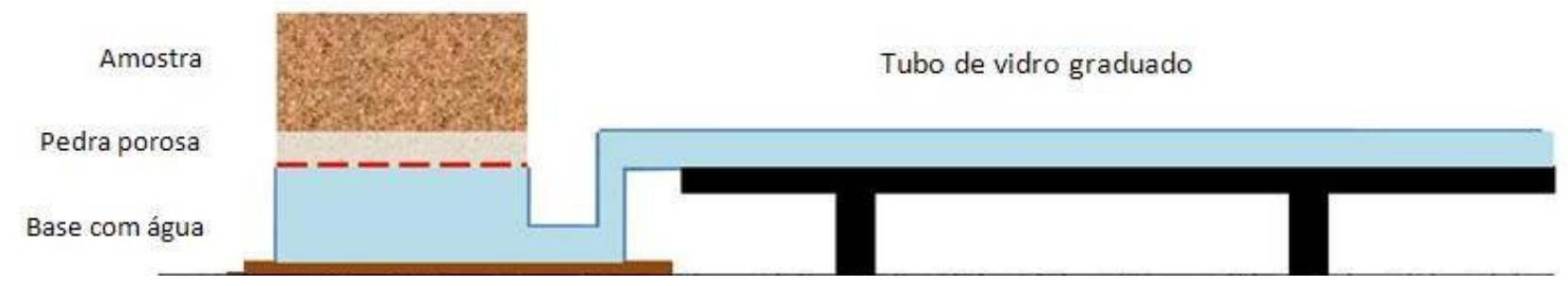

Figura 17 - Elementos do Ensaio de Absorção de Água

O índice de absorção $\left(I_{a b s}\right)$ pode ser obtido montando-se um gráfico do volume de água absorvido por unidade de área da base do corpo de prova $(q)$ versus a raiz quadrada do tempo $(\sqrt{t})$, segundo a formulação proposta pelos autores:

$$
I_{a b s}=\frac{q}{\sqrt{t}}
$$

\subsubsection{Ensaio de Perda de Massa por Imersão}

Imediatamente após o ensaio de absorção de água, deve-se colocar uma pedra porosa presa à base do cilindro contendo a amostra e, coloca-se o conjunto em um recipiente com água, ficando o topo da amostra na horizontal e abaixo do nível desta por $2 \mathrm{~mm}$, aproximadamente.

O conjunto deve ser mantido na posição horizontal até que não existam mais modificações de umidade perceptíveis na superfície livre do topo da amostra. Em sequência, emerge-se este conjunto e gira-se até que a superfície livre da amostra fique na vertical, imergindo-o novamente em um recipiente com água (na nova posição).

Cuidados devem ser tomados para que a parte inferior da superfície livre da amostra, fique a cerca de $30 \mathrm{~mm}$ do fundo do recipiente com água e dentro de um recipiente que permita a coleta do material desprendido desta superfície livre. Pelo período de 24 horas mantêm-se esta condição de imersão, e após, determina-se o percentual da perda de massa $(P)$ em relação à massa seca inicial da amostra (Figura 18).

O índice de erodibilidade proposto por Nogami \& Villibor (1979) é calculado com a seguinte expressão: $E=52 I_{a b s} / P$, onde $I_{a b s}$ e $P$ são os valores determinados em cada etapa do 
método. Se $E<1$, considera-se que o material possui alta erodibilidade. Se $E>1$, o material é classificado como não-erodível. Porém, Pejon (1992) concluiu que o índice de erodibilidade $(E)$ não é uma medida quantitativa do potencial à erosão dos materiais, portanto, não deve ser admitido que valores de " $E$ " mais elevados indiquem menor erodibilidade.

Desta forma, este índice deve ser considerado apenas como um indicativo qualitativo em trabalhos de mapeamento geotécnicos, não devendo ser utilizado diretamente no caso de obras, onde estudos locais e mais detalhados devem ser executados.

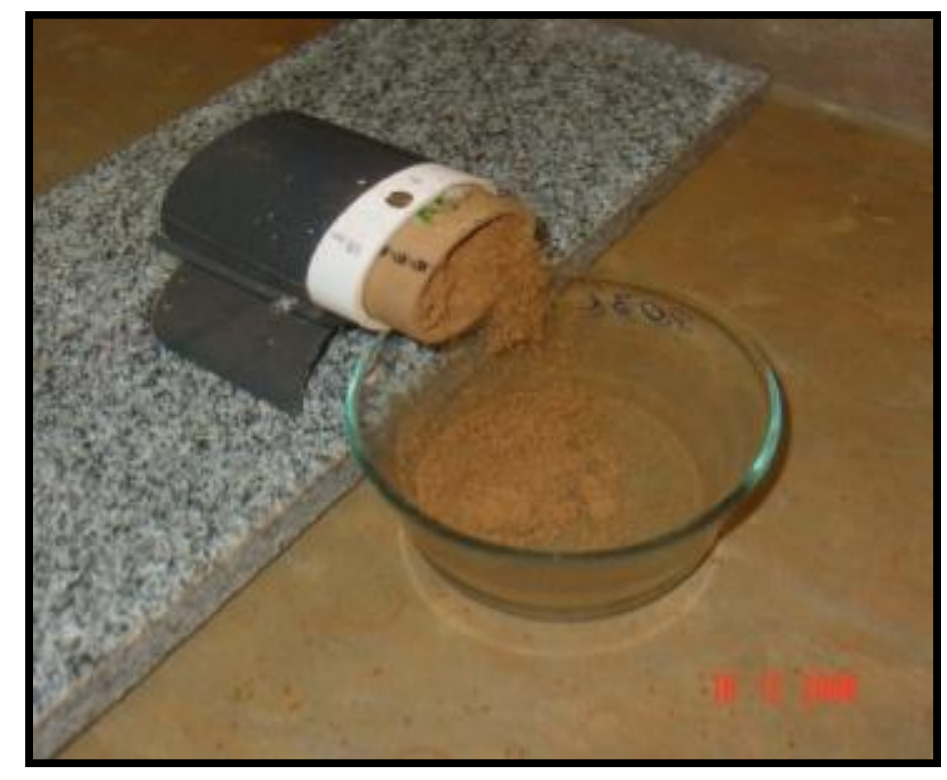

Figura 18 - Ensaio de Perda de massa por imersão

\subsection{MEDIDA E CONTROLE DA SUCÇÃo}

Presa (1988) criticou a qualidade dos equipamentos e das técnicas de ensaio em solos não saturados, que mesmo com as grandes melhorias apresentadas naquela época, segundo ele, possuiam desenvolvimento incipiente. Porém, mesmo em meados da década de oitenta, as técnicas de medida e controle de sucção foram elogiadas pelo autor no que tange à determinação de parâmetros volumétricos e de resistência.

Beneveli (2004) relata que a medição da sucção em solos não-saturados é de grande relevância para a compreensão do seu comportamento mecânico. Porém, apesar de se ter entendimento sobre o modelo constitutivo destes solos, ainda existem dificuldades na medição da sucção mátrica, principalmente quando se tem que determiná-la in situ. 
Soto (2004), que apresenta maiores detalhes de cada ensaio específico para a medida da sucção, recomenda que se deve recorrer a diferentes técnicas com intuito de conhecer-se o potencial dentro de uma faixa ampla, que seja suficiente para utilização prática, visto que as medidas de sucção tanto em laboratório como em campo esbarram numa série de dificuldades experimentais.

Na Ciência Geotécnia, os ensaios de sucção são realizados freqüentemente com a finalidade de estimar a sucção do solo sem sobrecarga e em determinadas condições de umidade, índices de vazios e estrutura, além de algumas vezes serem utilizados para a determinação da curva de sucção versus teor de umidade (Presa, 1988).

Beneveli (2004) e Feuerharmel (2004) classificaram os instrumentos de medição da sucção em dois grandes grupos: os de medida direta, como o tensiômetro, a centrífuga, placa de sucção, psicrômetro e o aparelho de membrana de pressão; e os de medida indireta, como o sensor térmico, o papel filtro, o dessecador de vazios e a balança de absorção.

Enquanto a medida direta mensura a energia da água nos poros, a medida indireta de sucção permite quantificar outros parâmetros ou propriedades do solo como resistividade e propriedades térmicas, por exemplo. Estes parâmetros variam com a umidade e, portanto, com a sucção do solo que, através de calibrações, pode ser relacionada com os parâmetros medidos.

Vilar (2000) e Soto (2004) sintetizam, comparam e reúnem as principais características dos métodos de medida e controle de sucção, adicionando algumas referências básicas acerca deles, como mostrado na Tabela1:

Tabela 1 - Métodos de medida de sucção (Vilar, 2000)

\begin{tabular}{|c|c|c|c|c|}
\hline MÉTODO & TIPO & SUCÇÃO & $\begin{array}{c}\text { FAIXA DE } \\
\text { MEDIDA (KPa) }\end{array}$ & OBSERVAÇÕES \\
\hline $\begin{array}{c}\text { FUNIL DE PEDRA } \\
\text { POROSA }\end{array}$ & Laboratorial & Matricial & 0 a 70 & $\begin{array}{l}\text { - Para baixas sucções, onde a precisão das } \\
\text { panelas é limitada; } \\
\text { - Sucção aplicada diretamente à amostra. }\end{array}$ \\
\hline CÂMARA DE PRESSÃO & Laboratorial & Matricial & 0 a 1500 & $\begin{array}{l}\text { - Emprega a técnica de translação de } \\
\text { eixos; } \\
\text { - A capacidade depende da pedra porosa } \\
\text { (pressão de entrada de ar); } \\
\text { - Continuidade da fase ar. }\end{array}$ \\
\hline $\begin{array}{c}\text { MEMBRANA DE } \\
\text { PRESSÃO }\end{array}$ & Laboratorial & Matricial/Total & Até 10000 & $\begin{array}{l}\text { - Emprega a técnica de translação de } \\
\text { eixos; } \\
\text { - Emprega membrana de celulose } \\
\text { (seletividade). }\end{array}$ \\
\hline
\end{tabular}


Tabela 1 - Métodos de medida de sucção (Vilar, 2000) - continuação

\begin{tabular}{|c|c|c|c|c|}
\hline TENSIÔMETRO & Laboratorial/In situ & Matricial & 0 a 70 & $\begin{array}{l}\text { - Tempos de resposta em função da } \\
\text { condutância da pedra porosa; } \\
\text { - Tensiômetros Osmóticos; } \\
\text { - Tensiômetros de alta capacidade } \\
\text { (medem pressões abaixo de }-1 \text { atm), } \\
\text { tirando partido da elevada resistência à } \\
\text { tração da água. }\end{array}$ \\
\hline PAPEL FILTRO & Laboratorial & Matricial/Total & Todos os valores & $\begin{array}{l}\text { - Necessita precisão máxima na pesagem. } \\
\text { - A determinação da sucção depende do } \\
\text { contato com o solo (garantir o contato } \\
\text { parece problemático); } \\
\text { - Calibração, fungos. }\end{array}$ \\
\hline BLOCOS POROSOS & Laboratorial/In situ & Matricial & 10 a 1000 & $\begin{array}{l}\text { - Condutividade elétrica de materiais } \\
\text { porosos (gesso, fibra de vidro, etc); } \\
\text { - Histerese pronunciada; mais sensível às } \\
\text { altas sucções; } \\
\text { - Longo tempo de resposta; } \\
\text { - Fácil deterioração do material; }\end{array}$ \\
\hline PSICRÔMETROS & Laboratorial/In situ & Osmótica & 100 a 8000 & $\begin{array}{l}\text { - Mais recomendado para laboratório; } \\
\text { - Depende de rigoroso controle da } \\
\text { temperatura, principalmente nas baixas } \\
\text { sucções; } \\
\text { - Sucção osmótica: mede sucção de } \\
\text { extrato da solução do solo } \\
\text { (confiabilidade precária). }\end{array}$ \\
\hline $\begin{array}{l}\text { SENSORES DE } \\
\text { CONDUTIVIDADE } \\
\text { TÉRMICA }\end{array}$ & Laboratorial & Matricial & 0 a 400 & $\begin{array}{l}\text { - Cápsula cerâmica contendo sensor de } \\
\text { temperatura e mini- aquecedor; } \\
\text { - Condutividade térmica do bloco varia } \\
\text { com a sua umidade; } \\
\text { - Equilíbrio solo - cápsula (bloco) > sucção } \\
\text { matricial medida a partir da } \\
\text { condutividade }\end{array}$ \\
\hline $\begin{array}{c}\text { EXTRATO DA SOLUÇÃO } \\
\text { DO SOLO }\end{array}$ & Laboratorial & Osmótica & Todos os valores & $\begin{array}{l}\text { - Condutividade do extrato; } \\
\text { - Concentração de solutos; } \\
\text { - Extrato e psicrômetro (resolução não } \\
\text { satisfatória). }\end{array}$ \\
\hline $\begin{array}{c}\text { EQUILÍBRIO DA FASE } \\
\text { VAPOR }\end{array}$ & Laboratorial & Total & Toda a faixa $>400$ & $\begin{array}{l}\text { - Solução com concentração e umidade } \\
\text { relativa conhecida; } \\
\text { - Amostra de solo em dessecador sem } \\
\text { contato com a solução; Equilíbrio } \\
\text { demorado. }\end{array}$ \\
\hline $\begin{array}{l}\text { PRINCÍ́PIOS } \\
\text { OSMÓTICOS }\end{array}$ & Laboratorial & Matricial & 200 a 1600 & $\begin{array}{l}\text { - Membrana de celulose para diálise; } \\
\text { - Solução com concentração conhecida e } \\
\text { umidade relativa conhecida; } \\
\text { - Solução de PoliEtileno Glicol (PEG), peso } \\
\text { molecular 20.000; } \\
\text { - Útil para instalar e controlar sucção em } \\
\text { ensaios. }\end{array}$ \\
\hline
\end{tabular}


Das técnicas mencionadas na Tabela 1 e, de acordo com a literatura consultada, esforços são dispensados no melhoramento daquelas já existentes. Porém foram observadas novas tentativas de instrumentar as medidas de sucção e, consequentemente, a obtenção das curvas de retenção, como visto nas propostas de Fleming, 1994; Leong et al., 2003; Beneveli, 2004; Soto \& Vilar, 2004; Mahler, 2004 e 2005; Diene, 2005.

\subsubsection{Câmara de Pressão de Richards}

A câmara de pressão é um equipamento utilizado para a determinação de curvas de retenção de água no solo, ou seja, determinação do teor de umidade versus sucção sob condições de laboratório (Libardi, 1995, apud Pereira, 2004).

O equipamento consiste basicamente de uma câmara, hermeticamente fechada, construída para suportar altas pressões, com uma placa porosa de alta pressão de entrada de ar em seu interior, com vazios bastante diminutos, que permitem, dentro de certos limites, o fluxo de água, porém não o de ar (Figura 19 e Figura 20).

Estas placas, denominadas de placas de alta pressão de entrada de ar são o elemento chave para o controle da sucção neste equipamento. Aparatos deste tipo permitem solicitar o solo com pressões que podem atingir $1500 \mathrm{kPa}$, para pedras cerâmicas como elemento de interface, ou $10000 \mathrm{kPa}$ para membranas de celulose como elementos de interface (Fumió, 2004).

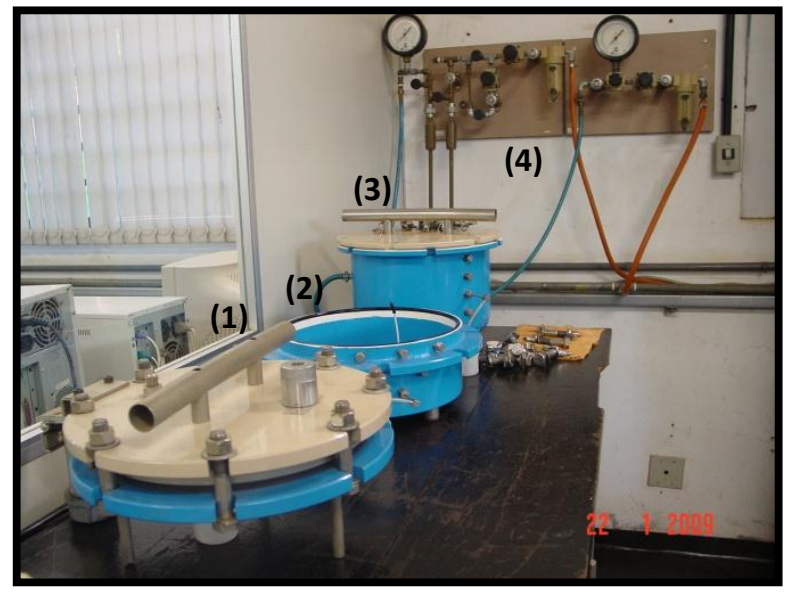

$\begin{array}{llll}\text { (1) } u_{2}-u_{m}>1500 & \text { (2) } u_{2}-u_{w}<1500 & \text { (3) } u_{2}-u_{w}<1500 & \text { (4) Painel }\end{array}$

Figura 19 - Câmaras de Pressão de Richards (EESC - USP)

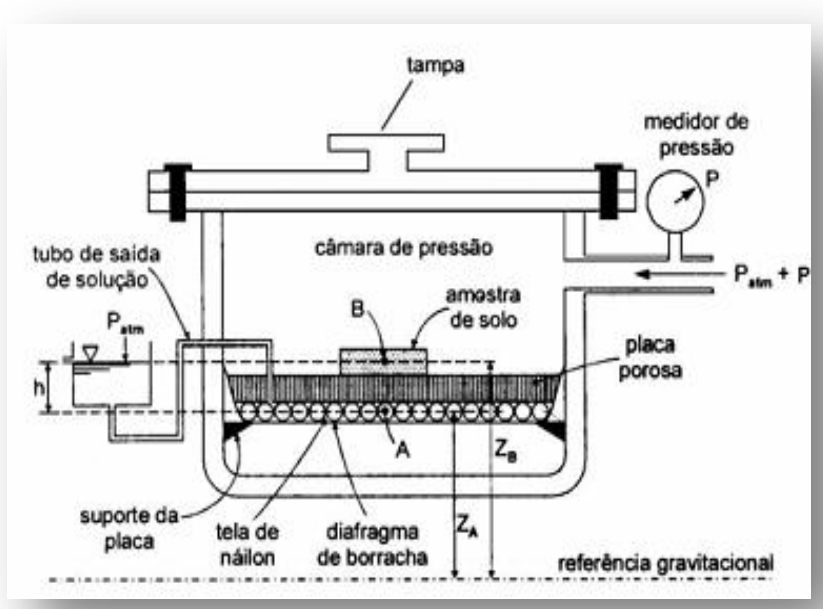

Figura 20 - Partes da Câmara de Pressão de Richards (Libardi, 1995 apud Pereira, 2004) 


\subsubsection{Vantagens e Limitações}

Gomes (2007) descreve as principais vantagens do método quando cita a possibilidade de se medir ou controlar a sucção. Além disso, o método pode ser incorporado a diversos tipos de equipamentos de ensaio, por exemplo: câmaras triaxiais, anéis edométricos, caixas de cisalhamento direto, entre outros.

Como aspectos desvantajosos desta técnica, ele enumera: o risco de se obterem valores superestimados de sucção para amostras com grau de saturação superior a $80 \%$ (ou para corpos-de-prova que contenham bolhas de ar oclusas); a possibilidade de se obterem valores subestimados de sucção em virtude de difusão de ar através da pedra porosa; e a possibilidade de ocorrer osmose, em função da qualidade da pedra porosa e do tipo de solo ensaiado.

\subsubsection{Funil de Placa Porosa}

O funil de placa porosa, também conhecido como "placa de sucção", consiste num sistema cujo funcionamento baseia-se no princípio dos vasos comunicantes. A amostra de solo é disposta sobre um disco cerâmico de alta entrada de ar, que por sua vez apóia-se sobre uma plataforma de altura regulável, como mostrado na Figura 21.

O disco cerâmico permanece hidraulicamente conectado a um reservatório d'água, que está sempre posicionado em uma cota inferior à da plataforma. É preciso saturar a pedra porosa antes de proceder à tomada de medidas pela placa de sucção (Gomes, 2007).

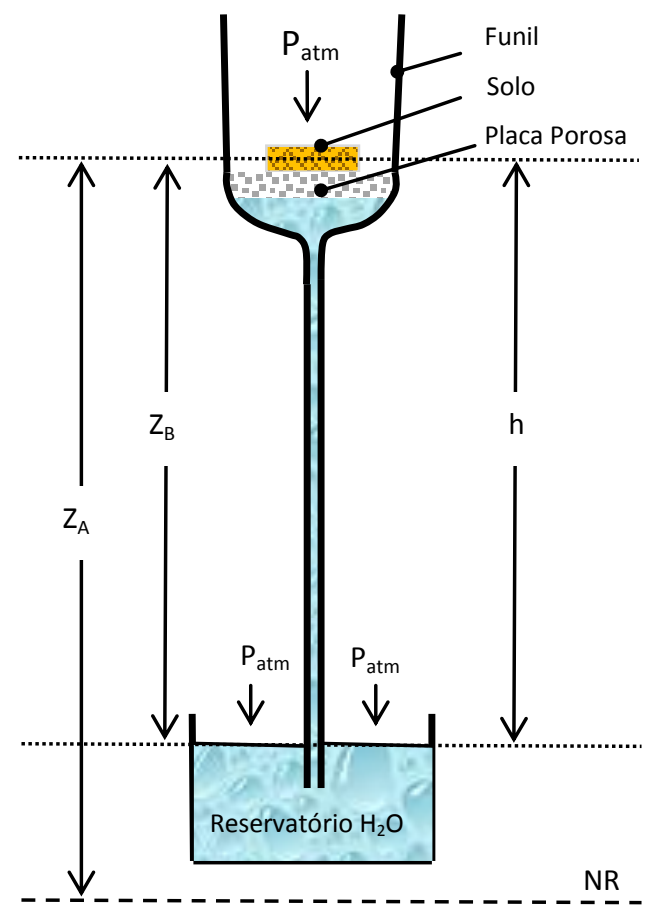

Figura 21 - Funil de placa porosa (modificado Reichardt, 1985 apud Röhm, 2004) 
Ainda sobre os procedimentos do ensaio, Gomes (2007) citando Oliveira (2004) recomenda que, para a saturação da pedra porosa, o conjunto apresentado na Figura 21 seja colocado no interior de um dessecador com água destilada para aplicação de vácuo, que é mantido até que não se observe saída de ar pela pedra porosa.

Logo após esta fase, a placa de sucção é retirada do dessecador e hidraulicamente conectada a um reservatório d'água. Novamente, imerge-se a placa porosa em água para o procedimento de aeração. Para tanto, o reservatório d'água deve estar em cota inferior à da pedra porosa. Neste trabalho, a pedra porosa foi saturada pela imersão em água destilada em período suficiente à observação de ausência de bolhas (saída de ar).

\subsubsection{Vantagens e Limitações}

A vantagem da técnica revela-se na sua exequibilidade sendo simples por dispensar o uso de compressores de ar e de câmaras herméticas. Além disso, as aferições de sucção realizadas por meio deste equipamento não apresentam problemas quanto à estabilização dos valores de pressão na água medidos.

Esta técnica apresenta limitações na sua aplicabilidade, devido à ocorrência de cavitação no reservatório de água e à pressão de borbulhamento da pedra porosa, que é a pressão de sucção a partir da qual o ar consegue fluir através da pedra porosa, o que torna inviável a manutenção da pressão negativa na água. Portanto, esta técnica pode ser utilizada para baixas sucções (Wolle, 1988; Gomes, 2007).

\subsubsection{Tensiômetro}

A importância deste tipo instrumento foi inicialmente ressaltada por Terzaghi em 1950, no momento em que este recomendou a análise da variação da sucção do solo em estudos relacionados à estabilidade de taludes (Mahler, 2004).

O termo tensiômetro é amplamente utilizado para denominar instrumentos que fazem uso de uma ponta porosa fina, com alta resistência à entrada de ar quando saturada, que, colocada em estreito contacto com o solo, propicia uma medida direta da pressão negativa da água (em relação à atmosférica) existente nos vazios do mesmo (De Campos, 1994).

Para este autor, a medida de tal pressão é efetuada utilizando-se diferentes tipos de técnicas ou de sensores elétricos ou mecânicos. Independentemente da técnica ou sensor de medição, requer-se, entretanto, a existência de uma coluna d'água contínua, que possibilite a 
transmissão da tensão da água na ponta porosa fina (em equilíbrio com o solo) até o sistema de medição de pressão.

Diversas pesquisas e estudos geotécnicos têm apresentado inúmeros modelos de tensiômetros que foram desenvolvidos e vêm sendo usados para o monitoramento do comportamento das pressões na água, particularmente em aplicações e pesquisas relacionadas ao estudo da mecânica dos solos (Mahler, 2004).

Gomes (2007) classifica a técnica tensiométrica segundo dois equipamentos não muito distintos, porém com diferentes capacidades de medição de sucção, são eles: o tensiômetro convencional e o tensiômetro de alta capacidade. $\mathrm{O}$ primeiro mede sucções que variam entre zero e $90 \mathrm{kPa}$ sendo que, valores maiores do que este podem causar cavitação no interior do aparelho; o segundo possibilita a medição de sucções em torno de $1 \mathrm{MPa}$ e consiste de um transdutor acoplado a uma cápsula de aço inoxidável, uma pedra porosa e água. Segue exemplo ilustrativo na Figura 22.

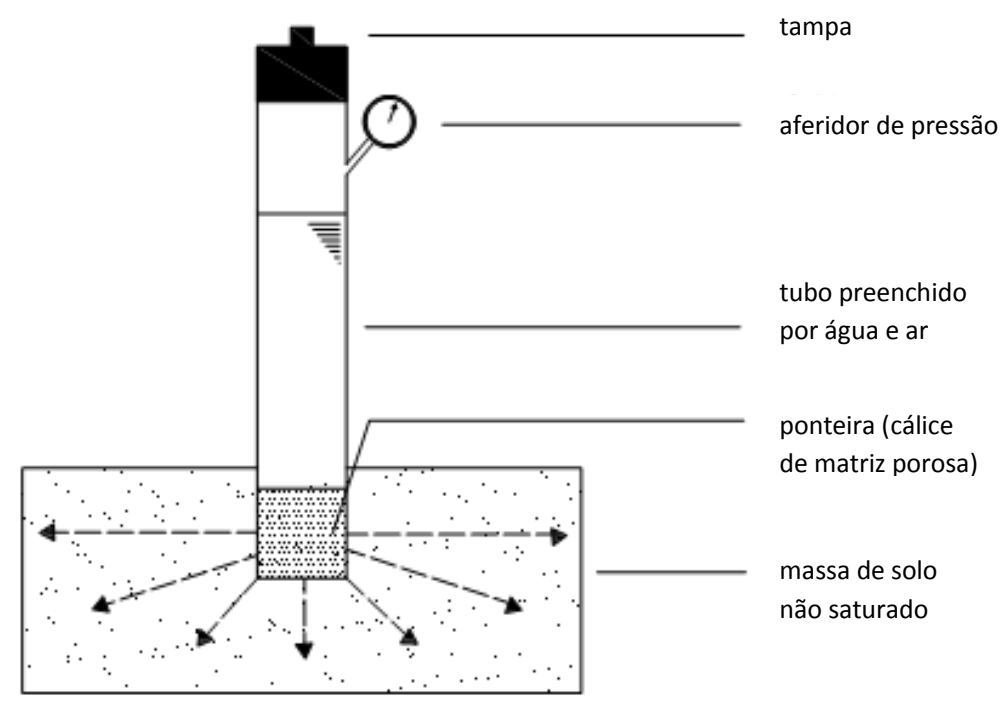

Figura 22 - Esquema de um tensiômetro convencional (Gomes, 2007)

\subsubsection{Vantagens e Limitações}

Segundo Gehling (2004), as vantagens e limitações dos tensiômetros, principalmente os de alta capacidade, podem ser listadas como:

- Permite a medição direta da sucção mátrica em laboratório e em campo $\leq 1500 \mathrm{KPa}$; 
- O tempo de resposta é rápido em relação aos tensiômetros convencionais;

- Garante a saturação da ponta porosa colocada em contato com o solo;

- Porém, é necessidade a pressurização da água para dissolver todo ar livre;

- Ocorrem efeitos de evaporação na superfície de contato tensiômetro-solo durante a medição em amostras com texturas muito porosas.

\subsubsection{Papel Filtro}

Marinho (2006) relata que o Método do Papel Filtro tem sido usado desde meados de 1937 quando foi apresentado por Gardner, para então ser largamente usado por inúmeros estudiosos na medida da sucção através de calibrações (Bullut, 2005; Feuerharmel, 2006). Segundo o autor, o método é bastante simples, porém, exige extremo cuidado no manuseio além de exigir do pesquisador conhecimento das propriedades geotécnicas dos solos em análise. Essa técnica é amplamente discutida por Fredlund (1993).

O método do papel filtro baseia-se no princípio de que a água existente num solo irá fluir deste para um material poroso com capacidade de absorver água, quando os mesmos estiverem em contato, até que se atinja o equilíbrio final no sistema. Um solo, com alguma umidade, quando é posto em contato com um papel filtro, com umidade menor, faz com que este último absorva uma certa quantidade de água do solo até que o sistema entre em equilíbrio de pressão (Hernandez Moncada, 2004).

É colocado um papel filtro de características conhecidas num ambiente hermético junto com uma amostra de solo. O estado de equilíbrio entre o papel filtro e o solo, permite determinar a sucção do solo usando uma curva de calibração do papel. Teoricamente, se o papel filtro encontra-se em pleno contato com o solo, a medida de sucção obtida corresponde à sucção mátrica e as sucções totais são medidas indiretamente se o papel filtro não se encontra em contacto direto com o solo (Fredlund, 1993; Gehling, 2004).

Normalmente papel filtro "quantitativo", tipo 2 é utilizado, sendo que, os mais usados são Whatman $\mathrm{N}^{\circ} 42$ (capacidade de absorção de umidade entre 6\% a 175\%) e Scheicher \& Schell $\mathrm{N}^{\circ} 589$, conforme exemplo mostrado na Figura 23. Como já mencionado, dependendo do tipo de contato entre o papel e o solo, o papel filtro pode medir tanto sucção mátrica quanto total. O papel filtro, na medição de sucção mátrica, fica em contato com o solo e atua como uma membrana permeável à água e solutos, ou seja, a solução intersticial é permitida se 
mover através do papel; a transferência de água do solo para o papel é feita por capilaridade (Figura 24).

No caso da medição da sucção total, o papel não fica em contato com o solo, e então o ar que fica entre o papel filtro e o solo atua como membrana semipermeável. Neste caso a transferência é feita através de vapor, e o vapor antes de ser absorvido pelo papel filtro deve superar as forças matricial e osmótica para sair do solo (Marinho, 1997).

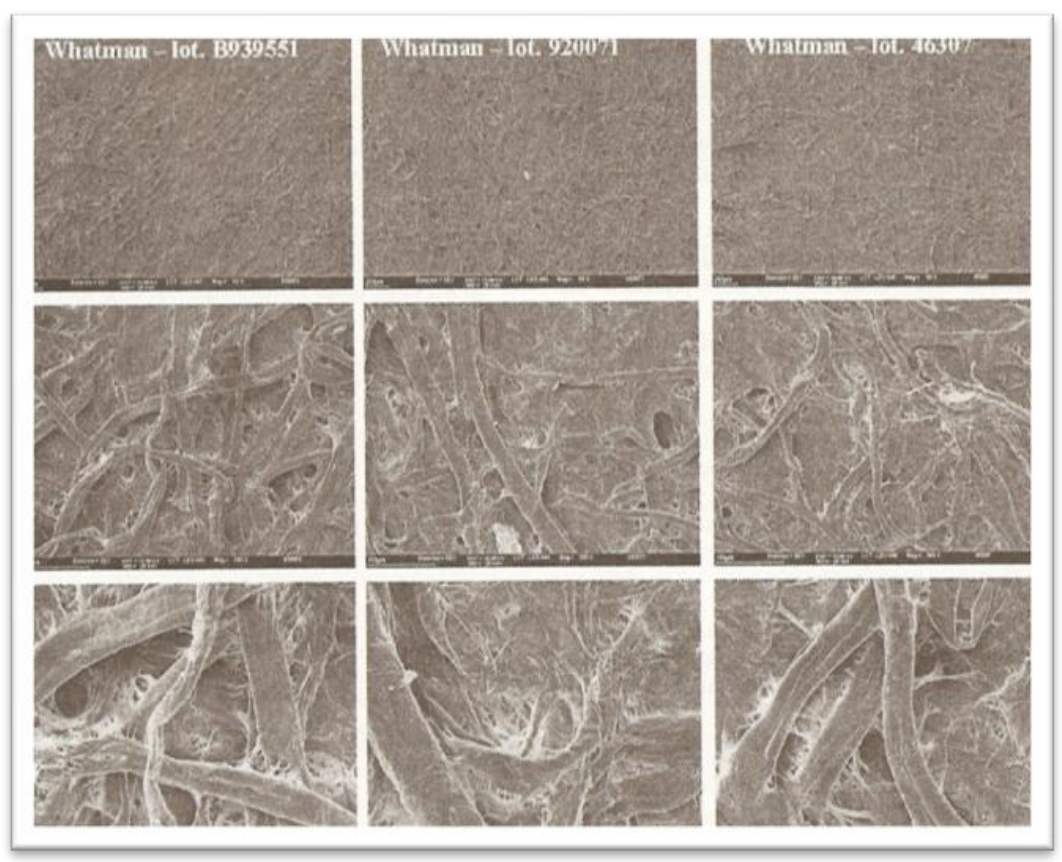

Figura 23 - Diferentes lotes do Papel Whatman Nº 42 (Marinho, 2006)

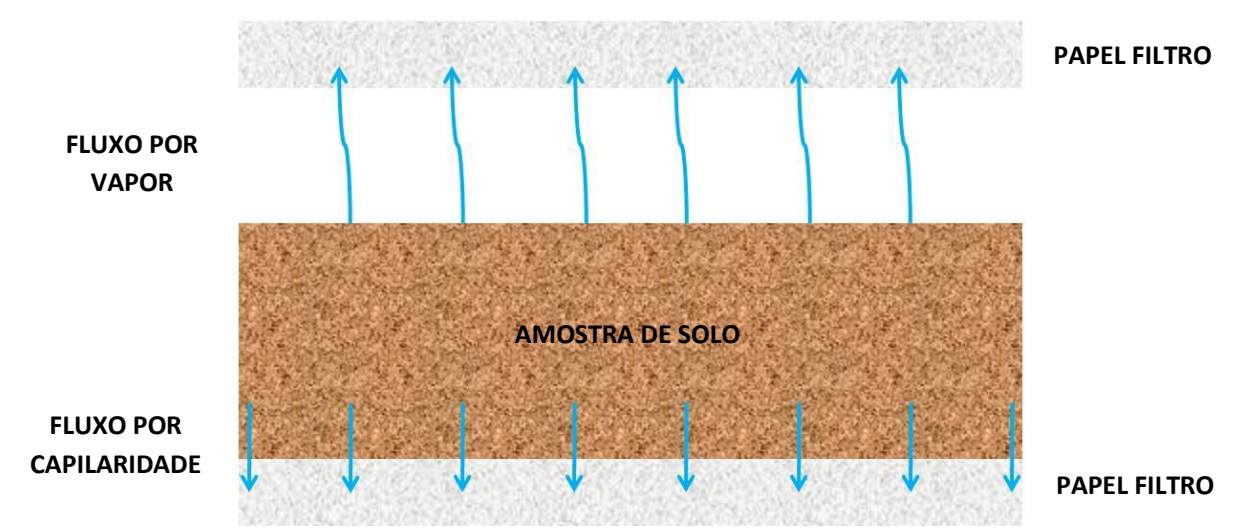

Figura 24 - Esquema de transferência de água do solo para o Papel Filtro 


\subsubsection{Vantagens e Limitações}

As vantagens e desvantagens são, conforme De Campos (1994):

- Para cada faixa de equilíbrio, o tempo de resposta do papel é rápido não ultrapassando mais que 7 dias;

- A faixa de medida de sucção da ordem de 5 a 15000 kPa;

- Oferece economia e uma precisão similar aos métodos convencionais;

- Possibilita a medição da sucção osmótica pela diferença entre as medidas de sucção total e sucção mátrica;

- É um método simples;

- Porém, requer o manuseio delicado e precisão na pesagem em balanças de alta resolução;

- O tempo do papel é relativamente longo para cada equilíbrio, sendo da ordem de 30 dias para sucções de 0 a 100kPa, quando medida a sucção total;

\subsection{CURVAS DE RETENÇÃO DE ÁGUA}

Também conhecidas como curvas de sucção e curvas características, são uma função da relação entre tensão de sucção e capacidade de retenção da água nos poros de materiais, ou então, representam uma relação entre o potencial matricial e o teor de umidade ou grau de saturação do solo. Podem se relacionar com as variáveis dependentes de presença da água livre no solo (grau de saturação, teor de umidade por volume) (Freudland, 1993; Röhm, 2004).

A natureza dessa relação está diretamente associada à distribuição de tamanho dos grãos e mineralogia do solo, tipo de solo, densidade e variação do teor de umidade. A geometria dos poros, a magnitude e composição mineralógica da fração fina definem posição, forma, e inclinação destas curvas (Fumió, 2004; Vieira, 1987).

A Curva de Retenção de Água, além de representar a capacidade que o solo tem de armazenar água, tem sido usada para a previsão e quantificação de diversos parâmetros de grande interesse na solução dos problemas geotécnicos, como a condutividade hidráulica e parâmetros de resistência ao cisalhamento. Isto é atrativo à prática, já que ensaios que 
quantifiquem estas propriedades podem ser muitas vezes onerosos e demoram muito tempo para serem desenvolvidos (Silva, 2005).

Sua determinação pode ser realizada em laboratório através dos procedimentos a seguir:

- Por secagem (desidratação ou dessorção), quando uma amostra previamente saturada é exposta a potenciais matriciais gradualmente maiores, com sucessivas medidas destes valores versus o teor de umidade de equilíbrio de cada estágio;

- Por molhamento (hidratação ou adsorção), quando uma amostra seca ao ar tem seu potencial matricial reduzido gradualmente, com sucessivas medidas do potencial versus o teor de umidade de equilíbrio em cada estágio.

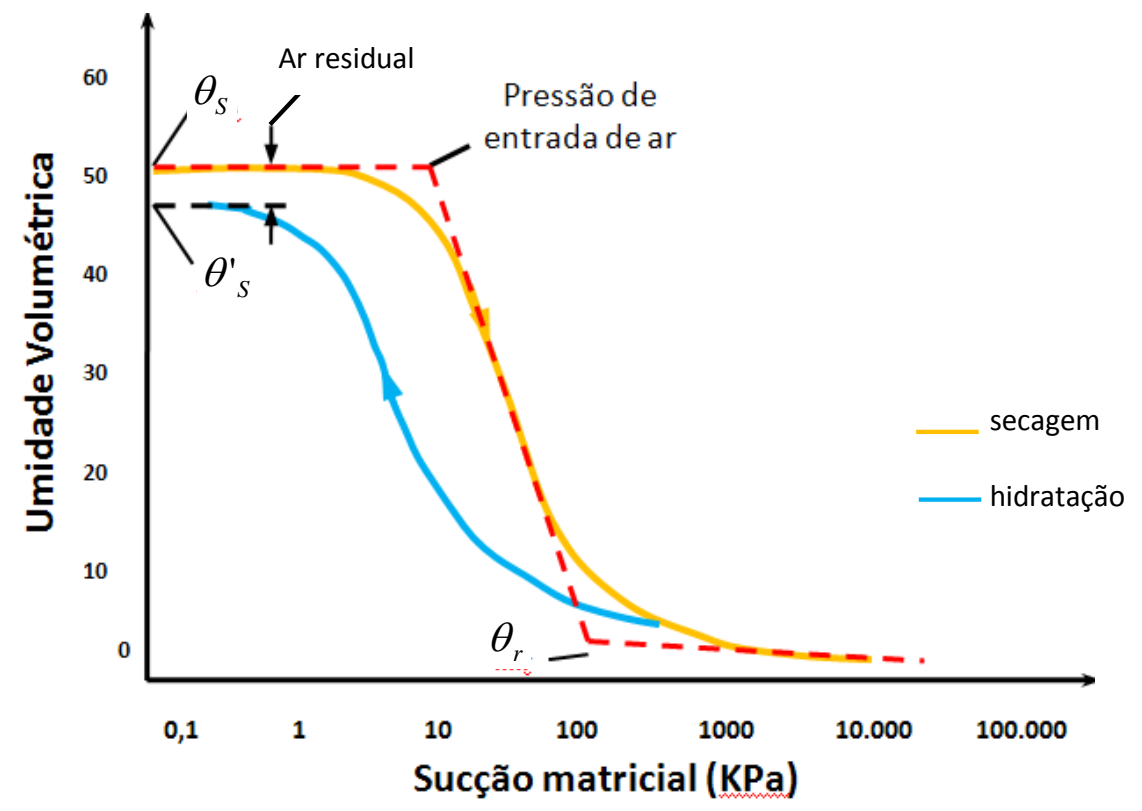

Figura 25 - Elementos da Curva de Retenção

A curva de retenção de água possui alguns elementos principais onde se destacam a umidade de saturação $\left(\theta_{S}\right)$, a pressão de entrada de ar e a umidade residual $\left(\theta_{r}\right)$, como visto na Figura 25. A pressão de entrada de ar, quando atingida, implica o início do esvaziamento do maior poro. Para valores inferiores a ela, o solo se mantém saturado, embora com pressões na água negativas. A umidade residual representa um valor abaixo do qual, praticamente, já não se consegue extrair água do solo com o aumento da sucção (Vilar, 2000). 
As características que distinguem as Curvas de Retenção dependem de vários fatores como a estrutura do solo (e sua agregação), teor de umidade inicial ou de moldagem, índice de vazios, tipo de solo, textura, mineralogia, histórico de tensões e método de compactação. Estes fatores podem interferir na forma da Curva de Retenção de diferentes maneiras, cada um se sobressaindo ao outro, dependendo do tipo de solo, como visto na Figura 26.

Amostras de um solo em particular, apesar de ter a mesma textura e mineralogia, podem exibir diferentes Curvas de Retenção se forem preparadas com diferentes umidades e possuírem diferentes histórico de tensões (Miller et al., 2002 apud Silva, 2005).

Conforme se pode observar da Figura 25, a curva característica de sucção é dependente da trajetória seguida durante o ensaio, se de secagem, umedecimento e mista. Neste último é identificado o fenômeno da histerese, quando para um mesmo solo as trajetórias de secagem e umedecimento não se sobrepõem.

O fenômeno da histerese é explicado por meio de diferentes causas, como a geometria não uniforme dos poros, intercomunicados por pequenas passagens, o efeito do ângulo de contato, que varia em função da trajetória seguida, a ocorrência de bolhas de ar aprisionadas, que influenciam a trajetória de umedecimento e as variações de volume sofridas por expansão e retração (Presa, 1994; Poulovassilis, 1962 e Hillel, 1980 apud Machado \& Zuquette, 2004).

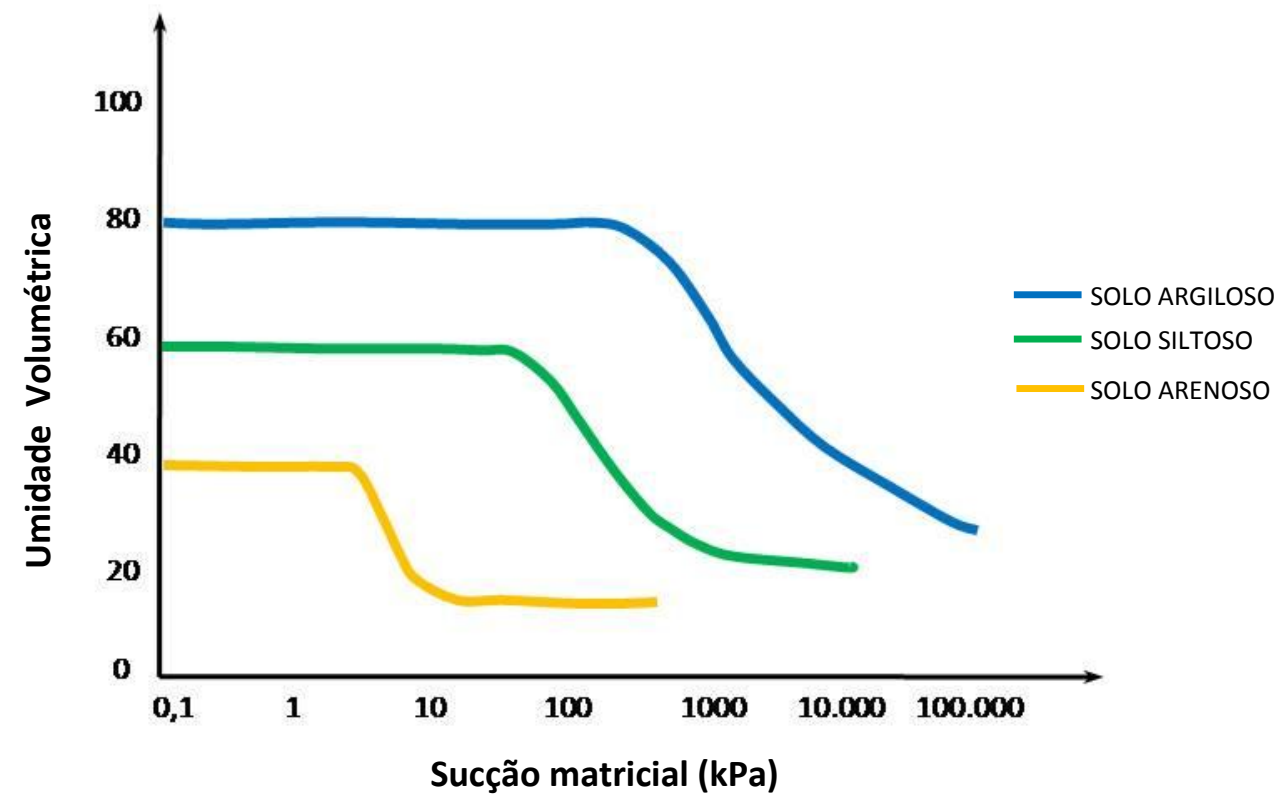

Figura 26 - Curvas de Retenção para diferentes solos 
Segundo Silva (2005) muitos fatores interferem na capacidade de retenção de água de um solo sendo que, Reichardt (1990) considera o tipo de solo como o principal deles, pois este define a área de contato entre as partículas sólidas e a água além de determinar as proporções de poros de diferentes tamanhos.

Outros fatores são a estrutura (determinando o arranjo das partículas e, por conseqüência, a distribuição dos poros) e a qualidade (composição) mineralógica do solo. Alguns argilo-minerais, por exemplo, têm ótimas propriedades de retenção de água, como as montmorilonitas, vermiculitas e ilitas, ao contrário da caulinita e gibsita.

A matéria orgânica, quando coloidal, apresenta boas propriedades de retenção de água e afeta uma das principais características físicas do solo, a agregação do solo, afetando assim, indiretamente, outras características como a densidade, porosidade, aeração e infiltração de água. Sendo que a capilaridade e a adsorção são os fenômenos responsáveis por esta retenção.

Custódio e Vieira (2004) também estudaram os fatores que controlam a curva característica de retenção da água no solo, tais como: efeito da histerese devido aos ciclos de recarregamento e descarregamento, em conseqüência da descompressão da câmara durante a pesagem das amostras; procedimentos de ensaios envolvendo a saturação das amostras ou secagem das mesmas; influência da altura da amostra de solo e as técnicas de saturação em conformidade com duração do ensaio e a qualidade dos dados de ensaios ainda não são totalmente compreendidos.

Além dos trabalhos de Centurion (1997) e Lougon-Duarte (2004), outros estudos nesse âmbito foram realizados por Moraes et al. (1993) que estudou a influência da temperatura nas curvas de retenção pois, segundo ele, a tensão superficial diminui com a temperatura, o que leva à redução no teor de água a um dado potencial.

\section{MATERIAIS ESTUDADOS E CARACTERÍSTICAS DAS REGIÕES AMOSTRAIS}

As amostras de solo contidas neste trabalho foram coletadas em regiões diferentes com características próprias, desenvolvidas ao longo do tempo geológico. $\mathrm{O}$ estudo se concentra em regiões das cidades do interior paulista: São Carlos e São Pedro (SP). A escolha desses locais se deu com base em atributos já conhecidos e que foram evidenciados por estudos sobre os processos erosivos nessas regiões, intensificados a partir da década de 60 . 
Ao longo dos últimos anos, pesquisas foram justificadas pela combinação de fatores agravantes aos processos nos municípios, como as características do meio físico modificadas pelo uso e ocupação do solo não-planejados. Além do amparo histórico-social, tais fatores agravantes se relacionam com alguns aspectos do meio vistos a seguir.

\subsection{LOCALIZAÇÃO:}

\section{- São Carlos}

A região de São Carlos fica a centro-leste do Estado de São Paulo a 234 km da capital paulista, como visto na Figura 27, localizada em altitude próxima a 900 m do nível do mar. Seu acesso pode ser feito pela rodovia SP-310, limitando-se, ao norte, com os municípios de Rincão, Luís Antônio e Santa Lúcia; ao sul, com Ribeirão Bonito, Brotas e Itirapina; a oeste, com Ibaté, Araraquara e Américo Brasiliense; a leste, com Descalvado e Analândia.

\section{- São Pedro}

Outra região de amostragem se situa no município de São Pedro que se encontra geograficamente no centro-leste do Estado de São Paulo, distando $200 \mathrm{~km}$ da capital no sentido noroeste e $70 \mathrm{~km}$ sul da cidade de São Carlos. O acesso pode ser feito pelas rodovias SP-330 e SP-304, tendo na circunvizinhança, ao norte, os municípios de Itirapina e Torrinha; a leste, Charqueda; a oeste, Santa Maria da Serra e, ao sul, Piracicaba.

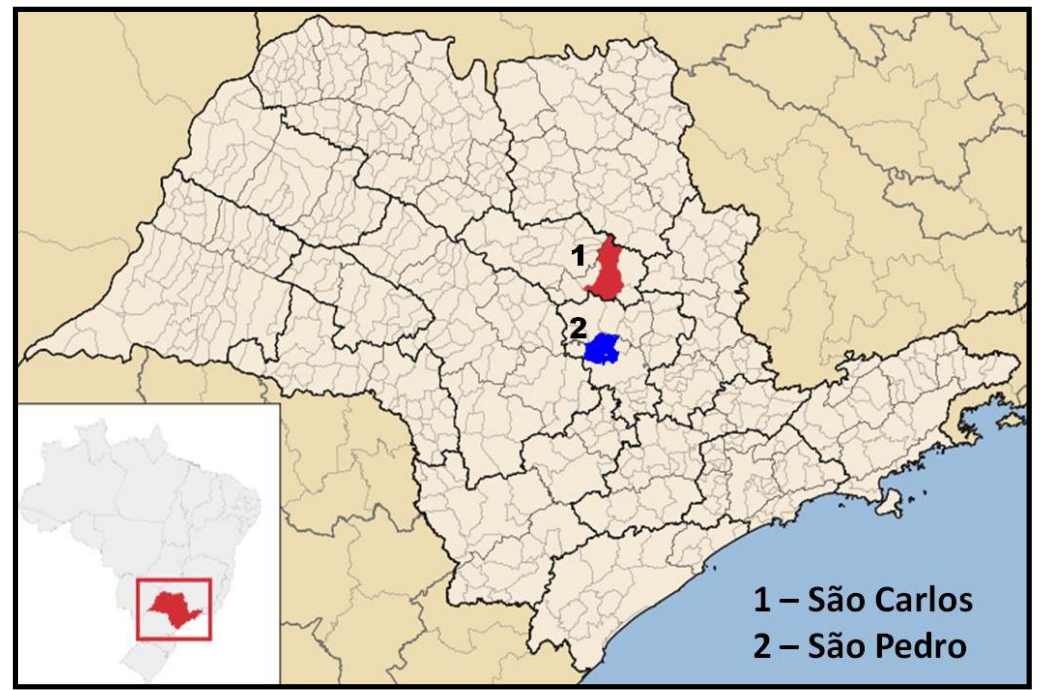

Figura 27 - Localização das regiões amostrais (modificado de http://pt.wikipedia.org/wiki) 
Os blocos amostrais foram retirados no interior de feições erosivas bem características dos solos do município (voçorocas), sendo usada metodologia de amostragem descrita mais adiante.

\subsection{ASPECTOS SÓCIO-ECONÔMICOS}

Segundo Rodrigues et al. (1993), em âmbito nacional, a região centro-leste do Estado de São Paulo se destaca por sua grande importância sócio-econômica devido a vários aspectos como por exemplo, possuir população acima de 4 milhões de habitantes com cerca de $80 \%$ localizada em áreas urbanas cobrindo cerca de 50 municipalidades classificadas, em sua maioria, como de médio e pequeno portes.

São Carlos, hoje, classifica-se como região de médio porte (entre 100 mil e 300 mil habitantes), com uma população acima de 220 mil habitantes. A cidade de São Pedro conta com cerca de 30 mil, sendo considerado um município de pequeno porte (de 20 mil a 100 mil habitantes).

Estas municipalidades participaram do crescimento econômico acelerado da região centro-leste paulista, resultante da expansão da atividade agrícola e do intenso processo de industrialização. Hoje, ainda, contribuem para o aumento do mercado consumidor na região, fomentado pela malha rodoviária que liga as muitas localidades.

A despeito dos dados favoráveis ao crescimento regional, algumas localidades sofrem as conseqüências deste desenvolvimento a todo custo. A área de São Pedro, por exemplo, vislumbra os efeitos de anos de cultivo, exploração e abandono do solo pela cultura canavieira ou uso para pastagens, através da intensificação dos processos de perdas de solos agricultáveis.

\subsection{MEIO FÍSICO}

Fúlfaro et al. (1993) lembra que o meio físico do Estado de São Paulo reúne agrupamento de rochas formadas em certos ciclos do tempo geológico que foram submetidas a movimentações tectônicas do Cenozóico. Esses processos da dinâmica interna da Terra atrelados às características litológicas e hidrológicas da região permitiram que o Estado de São Paulo fosse dividido em cinco províncias geomorfológicas (Figura 28):

a. Planalto Atlântico - predomínio de rochas cristalinas do Arqueano-Eopaleozóico 

b. Depressão Periférica - formada por sedimentos do Paleozóico
c. Cuestas Basálticas - rochas vulcânicas e sedimentos do Cretáceo
d. Planalto Ocidental - rochas vulcânicas e sedimentos do Cretáceo
e. Planície Costeira - depósitos sedimentares mais recentes

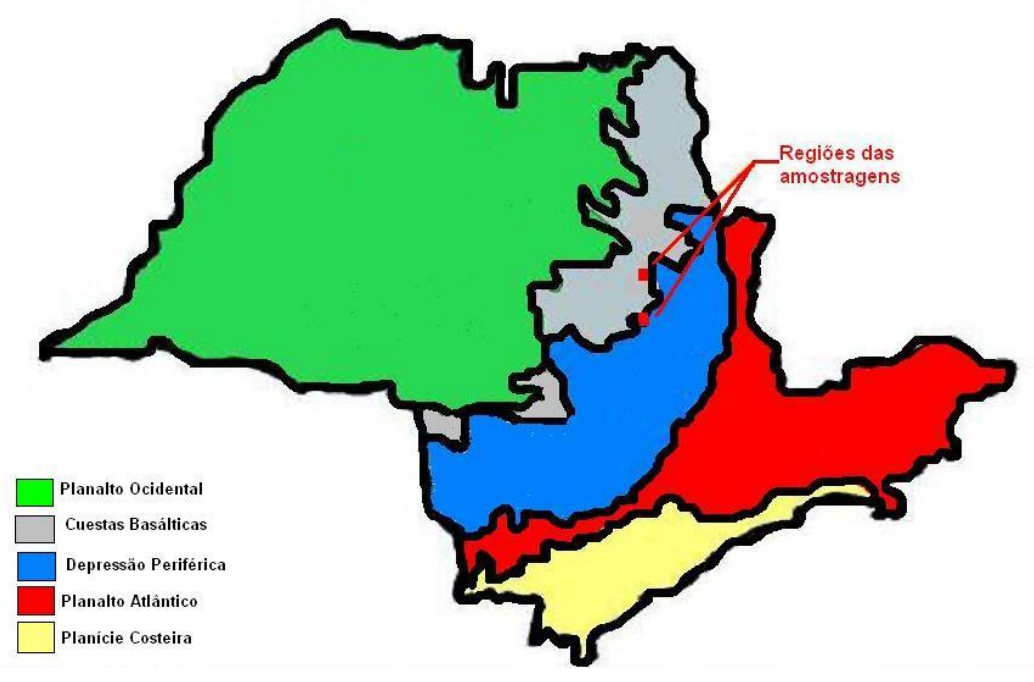

Figura 28 - Divisão Geomorfológica do Estado de SP (modificado de Zuquette, 1981)

\subsection{GEOMORFOLOGIA}

\section{- São Carlos}

Mapeamentos geotécnicos realizados na região de São Carlos mostram que esta faz parte da província geomorfológica das Cuestas Basálticas. Segundo Zuquette (1981), as cuestas representam a borda dos derrames basálticos e se formam devido ao baixo ângulo de mergulho das camadas para noroeste, à espessura e à alta resistência dos derrames.

As Cuestas se localizam entre as províncias do Planalto Ocidental e a Depressão Periférica. A cidade se situa num dos planaltos de reverso da cuesta interna chamado de Planalto Residual de São Carlos. O mesmo autor atenta para a formação de degrau destacado na topografia à sudeste da cidade, por causa da maior resistência à erosão do Arenito Botucatu silicificado que aí ocorre sotoposto aos magmatitos básicos. 
As altitudes do Planalto Residual de São Carlos variam de 600 a 900m, com vertentes de baixa declividade, entre 2 e 20\%, atingindo $30 \%$ apenas nas porções de relevo mais dissecadas. As formas de relevo predominante são as denudacionais, basicamente formadas por colinas de topos convexos e tabulares (Ross e Moroz, 1997 apud Velozo, 2006).

\section{- São Pedro}

Conforme estudos de Almeida (1964), esta região situa-se na província geomorfológica da Depressão Periférica Paulista, próximo ao limite com a escarpa das Cuestas Basálticas. A Depressão Periférica foi dividida por ele em três zonas: Médio Tietê, Paranapanema e Mogi Guaçú.

Dentre aquelas, a região estudada pertence à Zona do Médio Tietê, possuindo relevo com as seguintes características: pouco acentuado sob a forma de colinas; topos aplainados com áreas de 1 a $4 \mathrm{~km}^{2}$; vertentes apresentando perfis convexos a retilíneos; altitudes variando de 550 a 650 metros.

Duarte (1980) constatou que os rios que drenam a Depressão Periférica na região de São Pedro, tendo o rio Piracicaba como nível de base regional, achavam-se encaixados na cobertura e em plena atividade erosiva. A intensidade dos processos erosivos contribuíram para o assoreamento dos canais. E já nesta época, a competência dos ribeirões foi classificada como suficiente apenas para transportar sedimentos arenosos.

Os processos erosivos atuam rapidamente na geomorfologia da região que, tem no voçorocamento o agente mais deflagrador. A erosão se instala nos sedimentos coluviais arenosos, afetando grandes áreas e atingindo profundidades de até $30 \mathrm{~m}$.

\subsection{CLIMATOLOGIA}

Segundo a classificação climática de Köppen, baseada em dados mensais pluviométricos e termométricos, o Estado de São Paulo abrange sete tipos climáticos distintos, a maioria correspondente a clima úmido. O tipo dominante na maior área é o Cwa, que abrange toda a parte central do Estado e é caracterizado pelo clima tropical de altitude, com chuvas no verão e seca no inverno, com a temperatura média do mês mais quente superior a $22^{\circ} \mathrm{C}$. Algumas áreas serranas, com o verão ameno são classificadas no tipo $\mathrm{Cwb}$, onde a temperatura média do mês mais quente é inferior a $22^{\circ} \mathrm{C}$ e durante pelo menos quatro meses é superior a $10{ }^{\circ} \mathrm{C}$. 


\section{- São Carlos}

Tolentino (1967) relata que as primeiras informações oficiais sobre o clima de São Carlos datam de 1890 quando dados meteorológicos mostraram que a temperatura mínima neste período oscilou entre os valores de $0,4^{\circ} \mathrm{C}$ e $16^{\circ} \mathrm{C}$ observadas nos meses, respectivamente, Setembro e Dezembro; e as máximas observadas ocorreram entre os valores de $22^{\circ} \mathrm{C}$, em Junho, e $33^{\circ} \mathrm{C}$ em Dezembro.

Para o mesmo autor, a climatologia da região pode ser explicada por sua situação geográfica e topográfica pois a cidade, como já dito, localiza-se em bem caracterizado planalto pertencente à borda da linha de "cuestas". Estando a região de São Carlos flanqueada pelas escarpas desse planalto, bastante acentuadas ao Sul e ao Norte da cidade, ocorre uma situação tal que permite o estabelecimento de condições de circulação áreas típicas que geram circunstâncias favoráveis ao estabelecimento de um clima peculiar.

Outro fator determinante do clima regional é a altitude da cidade, que possui uma certa proeminência em relação à altimetria dos núcleos urbanos vizinhos, como visto na Tabela 2. Desta forma, a inexistência de obstáculos naturais (como serras, por exemplo) permite insolação e ventilação intensa da área, ao mesmo tempo que as escarpas acentuadas e as linhas de drenagem próximas e amplas contribuem para um escoamento rápido das águas pluviais com profundos reflexos sobre a evaporação e a umidade atmosférica.

Tabela 2 - Altimetria em relação ao nível do mar (adaptada de Tolentino 1967).

\begin{tabular}{|ll|lc|}
\hline \multicolumn{2}{|c|}{ Direção SE-NW } & \multicolumn{2}{c|}{ Direção S-N } \\
\hline Itirapina & 758,8 & Santo Inácio & 543,9 \\
Visconde de Rio Claro & 743,5 & Jacaré & 575,5 \\
Conde do Pinhal & 738,7 & Monjolinho & 661,5 \\
São Carlos & 856,0 & Angico & 715,7 \\
Retiro & 844,5 & São Carlos & 856,0 \\
Ibaté & 825,7 & Babilônia & 756,5 \\
Tamoio & 780,4 & Floresta & 699,2 \\
Chibarro & 653,0 & Canchim & 690,1 \\
Araraquara & 646,4 & Capão Preto & 690,2 \\
\hline
\end{tabular}


Dados mais recentes revelam em média as normais climatológicas da região, como mostrado na Tabela 3:

Tabela 3 - Normais climatográficas de São Carlos (modificado de Tolentino, 1967 e CepagriUnicamp, 2008).

\begin{tabular}{|lc|c|}
\hline Pressão atmosférica & $(\mathrm{kPa})$ & 92,1 \\
Temperatura do ar & $\left({ }^{\circ} \mathrm{C}\right)$ & 21,3 \\
Temperatura sensível & $\left({ }^{\circ} \mathrm{C}\right)$ & 17,1 \\
Temperatura Máxima & $\left({ }^{\circ} \mathrm{C}\right)$ & 27,0 \\
Temperatura Mínima & $\left({ }^{\circ} \mathrm{C}\right)$ & 15,3 \\
Umidade Relativa do Ar (verão-inverno) & $(\%)$ & $76-54$ \\
Evaporação média & $(\mathrm{mm})$ & 1431,0 \\
Precipitação média & $(\mathrm{mm})$ & 1512,0 \\
Nebulosidade (céu coberto) & $(\mathrm{décimos})$ & 4,7 \\
Ventos (velocidade média) & $(\mathrm{m} / \mathrm{seg})$ & 4,0 \\
\hline
\end{tabular}

Em suma, a caracterização climática de São Carlos pode ser dada segundo os sistemas de classificação abaixo:

- Koppen: Cwai - Awi, ou seja, clima temperado de inverno seco com transição para clima tropical com verão úmido e inverno seco. Amplitude térmica entre verão e inverno menor que $5^{\circ} \mathrm{C}$.

- Thornthwaite: BB'w, isto é, úmido mesotermal com deficiência de umidade no inverno.

\section{- São Pedro}

O clima na região é segundo a classificação de Koppen do tipo Cwa, mesotérmico com inverno seco, variando desde tropical na planície arenosa do Rio Jacaré Guaçu, até clima quase temperado. As altitudes variam de 580 a $950 \mathrm{~m}$ no alto da serra, onde a temperatura média anual é inferior a $19^{\circ} \mathrm{C}$, com amplitude térmica de $5,4^{\circ} \mathrm{C}$.

A região serrana, devido a altitude, apresenta a maior precipitação média anual, estando entre 1400 a 1500 mm, enquanto nas planícies desta área o total de chuvas chega a $1200 \mathrm{~mm}$. O período de maior excedente hídrico acontece de outubro a março com 82,6\% das chuvas; enquanto que o período seco se estende de abril a setembro, causado principalmente pela menor penetração do ar polar e à maior atuação da Massa Tropical Atlântica (Duarte, 1980; Oliveira 1997; Furquim 2002). 


\subsection{VEGETAÇÃO}

\section{- São Carlos}

No município de São Carlos ocorrem os seguintes tipos de vegetação: savana, floresta estacional, floresta secundária e vegetação ripária, além de áreas de reflorestamento. A floresta estacional está condicionada a fatores como estacionalidade do clima (verão chuvoso e inverno seco) e queda das folhas durante o período seco, em 20 a 50\% das árvores caducifólias da floresta (Miranda, 2005).

Porém, a área tem o cerrado como tipo predominante de vegetação original, sempre associado aos terrenos arenosos, que se caracteriza por plantas de pequeno porte, bastante desuniformes e associadas principalmente às gramíneas. Aos solos da formação Serra Geral, nas encostas, associa-se outro tipo de vegetação, caracterizado por árvores de médio porte e arbustos (Zuquette, 1981).

\section{- São Pedro}

A cobertura vegetal original da região, assim como de toda a Depressão Periférica, é a Floresta Latifoliada Tropical Semidecídua que está relacionada, como já dito, às estações climáticas e também à natureza dos solos que são, na maioria, arenosos e com pequena capacidade de retenção de água. Atualmente, esta formação vegetal cede lugar principalmente às pastagens, cultivos de cana-de-açúcar, havendo remanescentes de Mata Ciliar em algumas cabeceiras de drenagem (Oliveira, 1997).

Na região de São Pedro a mata ocorre apenas na borda da escarpa da cuesta. No glacis, ocorria o cerrado, hoje em manchas residuais. Atualmente predominam o campo antrópico, as pastagens e ainda culturas de cana, além de algumas ocorrências de cítricas, concentradas nas proximidades do rio Piracicaba (Furquim, 2001).

\subsection{PEDOLOGIA E GEOLOGIA}

No país, os latossolos são os mais importantes do ponto de vista de representação geográfica, pois ocorrem praticamente em todas as regiões e sobre diferentes tipos de rochas. No mapa de solos da América do Sul (Figura 29), baseado na classificação "Soil Taxonomy", dos EUA, a distribuição dos solos é zonal (latitude-altitude) e tem relação direta com o clima e a vegetação locais (Teixeira et al., 2003). 
Além das influências climáticas, o manto de intemperismo das regiões amostrais é produto das feições litológicas ali formadas. As áreas estudadas fazem parte da Bacia Sedimentar do Paraná que, de forma global, trata-se de uma bacia intracratônica, de forma elíptica, com eixo maior de direção NE-SW, coincidindo com o curso do rio Paraná. É constituída de rochas de natureza clástica, que datam desde o Siluriano (Paleozóico) até o Cretáceo Superior. Os sedimentos acumulados desde o Paleozóico nessa bacia alcançam quase 8.000 metros de espessura (Figura 30).

A litoestratigrafia que aflora nas regiões foi formada na etapa final da sedimentação da Bacia do Paraná talvez iniciada no Triássico Médio Inferior. Os solos de São Carlos e São Pedro foram influenciados em sua maioria pelas formações geológicas dos Grupos São Bento e Bauru além dos sedimentos cenozóicos (Fúlfaro, 1993).

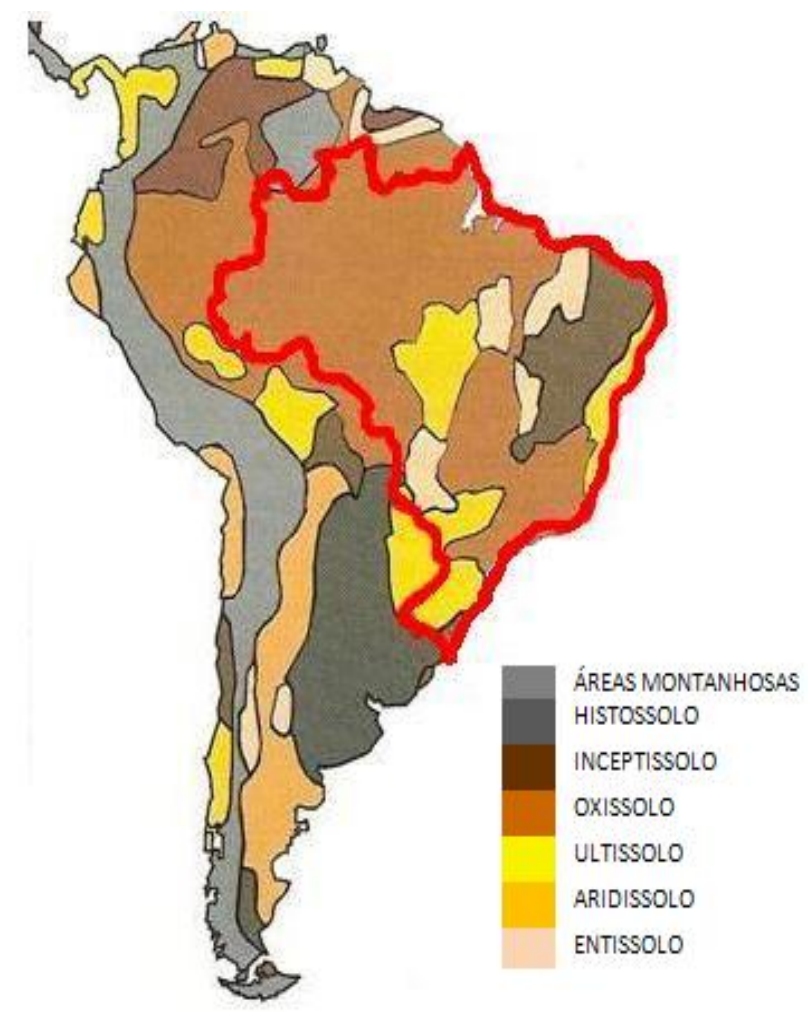

Figura 29 - Mapa de solos da América do Sul segundo Classificação Soil Taxonomy EUA (adaptado de Teixeira et al., 2003) 


\begin{tabular}{|c|c|c|c|c|c|c|c|c|}
\hline \multicolumn{3}{|c|}{ CRONOESTRATIGRAFIA } & \multicolumn{4}{|c|}{ LITOESTRATIGRAFIA } & \multirow[b]{2}{*}{ DESCRIÇÃO SUMÁRIA } & \multirow[b]{2}{*}{ AMBIENTE PROVÁVEL } \\
\hline$\underset{\varpi}{\mathbb{\sim}}$ & $\sum_{\frac{\omega}{\omega}}^{\overleftarrow{E}}$ & $\frac{w}{\tilde{\sim}}$ & $\begin{array}{l}0 \\
\frac{0}{2} \\
\frac{0}{0} \\
0\end{array}$ & FORMAÇÃO & LITOLOGIA & 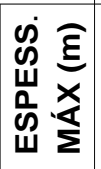 & & \\
\hline \multirow{2}{*}{$\stackrel{\bigcirc}{\mathrm{Z}}$} & Q & \multirow{3}{*}{ SUP } & \multirow{2}{*}{ 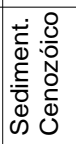 } & S/DENOMINAÇÃO & & 80 & Areias e aluviões & Aluvião e coluvião \\
\hline & $T$ & & & S/DENOMINAÇÃO & 80808 & 70 & Sedimentos areno-argilosos vermelhos & - \\
\hline \multirow{6}{*}{ 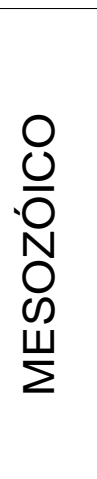 } & \multirow{3}{*}{ 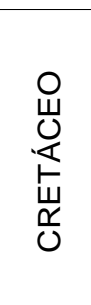 } & & \multicolumn{2}{|r|}{ BAURU } & & 200 & $\begin{array}{l}\text { Arenitos, siltitos calcíferos no topo, marrom avermelhado } \\
\text { com fósseis de vertebrados na base }\end{array}$ & Continental, fluvial e lacustre \\
\hline & & & \multirow{4}{*}{ 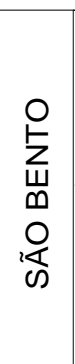 } & CAIUÁ & & 100 & Arenito vermelho com estratificação cruzada & Continental eólico \\
\hline & & INF & & SERRA GERAL & 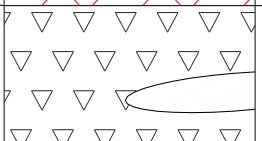 & 1850 & $\begin{array}{l}\text { Derrames de basalto com intercalações de } \\
\text { arenito eólico róseo amarelado }\end{array}$ & $\begin{array}{l}\text { Vulcanismo de fissura em clima } \\
\text { árido }\end{array}$ \\
\hline & $\frac{\pi}{2}$ & & & & & & & \\
\hline & \multirow{2}{*}{ 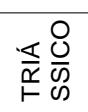 } & $\begin{array}{l}\text { SUP } \\
\text { MED }\end{array}$ & & $\begin{array}{l}\text { BOTUCATU + } \\
\text { PIRAMBÓIA }\end{array}$ & & 1200 & $\begin{array}{l}\text { Arenito róseo fino a médio bem arredondado com estratificação } \\
\text { cruzada, localmente conglomerático } \\
\text { Arenito e siltito argiloso vermelho muito fino com estratificação cruzada }\end{array}$ & $\begin{array}{l}\text { Continental eólico, localmente fluvial } \\
\text { Continental eólico, lacustre fluvial }\end{array}$ \\
\hline & & INF & $\#$ & 曲, & 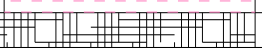 & - & Embasamento cristalino & Vulcanismo \\
\hline
\end{tabular}

Figura 30 - Feições Litoestratigráficas mais recentes da

Bacia Sedimentar do Paraná (Duarte, 1980) 
- Do Grupo São Bento:

Fazem parte deste grupo as Formações Pirambóia, Botucatu e Serra Geral que constituem um pacote de sedimentos arenosos, avermelhados associados à deposição de origem subaquosa, lacustre ou fluvial e eólica, sotopostos aos derrames basálticos mais recentes. Esses contatos litológicos se caracterizam pela ocorrência de intensos processos erosivos com conseqüentes materiais coluvionares dos arenitos retrabalhados.

As atividades erosivas são mais intensas na região de São Pedro (Figura 31) e foram quantificadas na região de São Carlos por Oliveira (1981), como visto na Tabela 4, que mostrou a influência da silificação e do intemperismo no potencial de absorção de água do Arenito Botucatu da região. A caracterização destas formações segue conforme os estudos de Duarte (1980) e Zuquette (1981) baseados em Soares (1972 e 1975); Pejon (1992); Fúlfaro (1993); CETESB (2008).

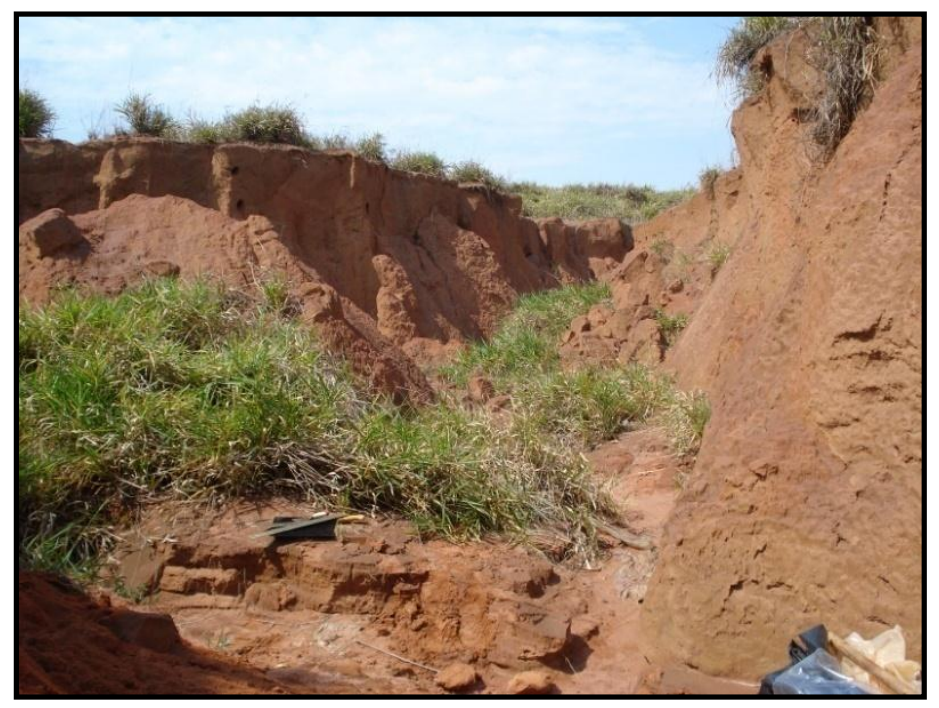

Figura 31 - Voçoroca na região de São Pedro

Tabela 4 - Absorção de água versus silificação do Arenito Botucatu na região de São Carlos (Oliveira et al., 1981).

\begin{tabular}{|c|c|c|c|c|}
\hline $\begin{array}{c}\text { Arenito silicificado em ordem } \\
\text { decrescente de silificação }\end{array}$ & $\begin{array}{c}\text { Com estratificação } \\
\text { cruzada do tipo eólico }\end{array}$ & $\begin{array}{c}\text { Com estratificação } \\
\text { cruzada }\end{array}$ & $\begin{array}{c}\text { Sotoposto ao } \\
\text { derrame basáltico }\end{array}$ & $\begin{array}{c}\text { Apresenta zonas de } \\
\text { decomposição física }\end{array}$ \\
\hline $\begin{array}{c}\text { Massa específica seca aparente } \\
\left(\mathrm{g} / \mathrm{cm}^{3}\right)\end{array}$ & \multicolumn{3}{|c|}{2,29} \\
\hline \begin{tabular}{c} 
Absorção de água $(\%)$ \\
\hline
\end{tabular} & 2,29 & 2,14 & 2,01 & 1,14 \\
\hline
\end{tabular}




\section{a) Formação Pirambóia}

De origem flúvio-lacustre, é caracterizada por arenitos argilosos esbranquiçados, amarelados, avermelhados e róseos; granulometria média a fina; com teor de finos aumentando de forma ascendente, tendo menor teor de argila $(<15 \%)$ na porção superior e cerca de $25 \%$ de finos na porção inferior sobreposta ao grupo Passa Dois (Formações Irati e Corumbataí); exibindo estratificação cruzada de pequeno a médio porte nas lentes menos argilosas superiores, com ocorrência também de estratificação plano-paralela nas lentes mais argilosas, como visto na (Figura 32).

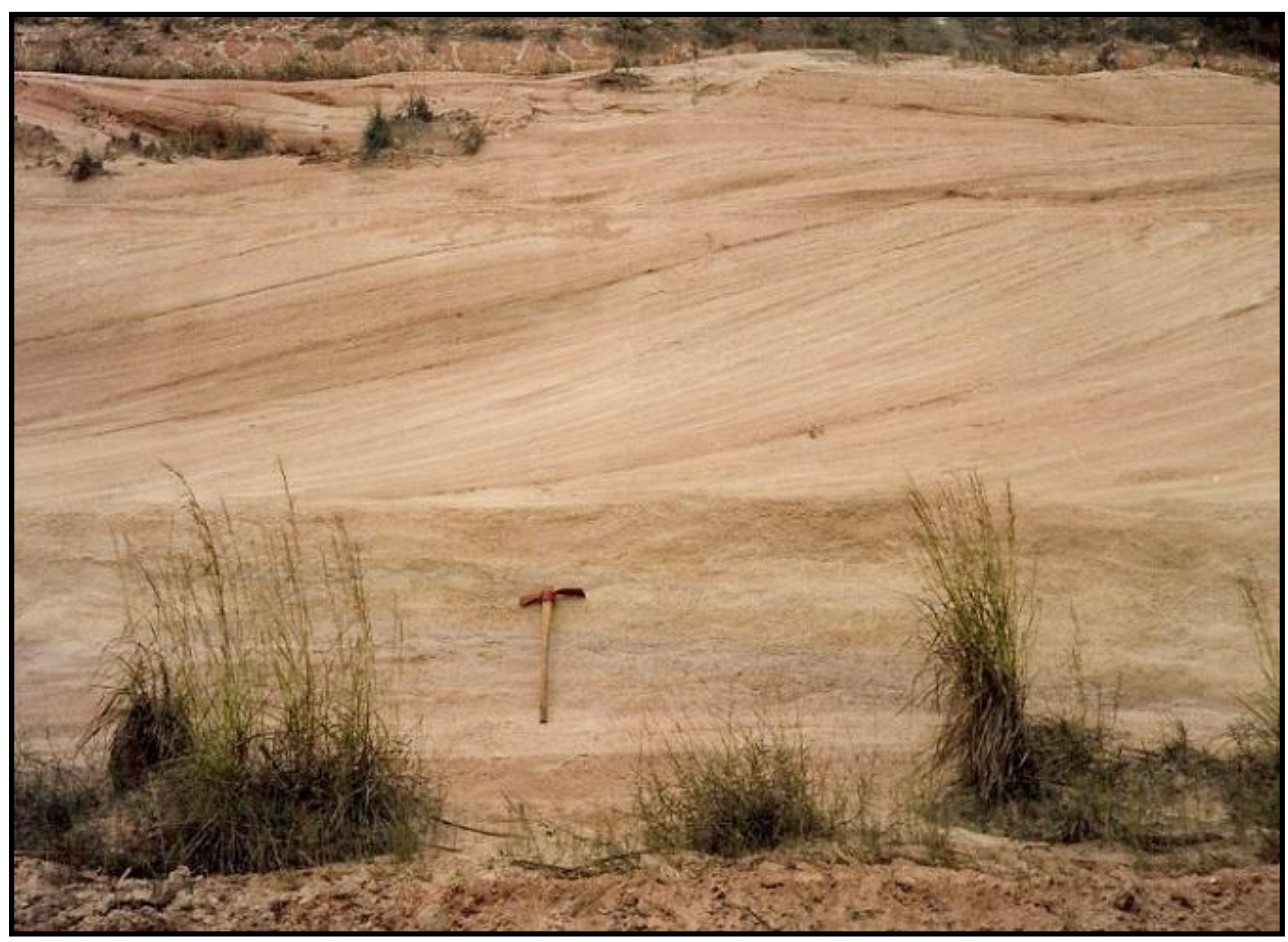

Figura 32 - Arenito Pirambóia. Estrada Charqueada a São Pedro (Pejon, 1992)

\section{b) Formação Botucatu}

Como visto na Figura 30, esta formação sucede à Pirambóia, existindo seções onde se encontram as duas fácies e outras com dominância de uma das duas. Pacote este que é sotoposto às eruptivas da Formação Serra Geral e separado desta por uma discordância erosiva.

Sua litologia é constituída por arenitos amarelados, de granulometria média a fina; com material síltico-argiloso inferior a 5\%; grãos com bom arredondamento e esfericidade; 
silicificados; alta resistência ao intemperismo (promovendo seu uso como material de revestimento na construção civil); estratificação cruzada de médio a elevado porte que chega a atingir uma centena de metros (Figura 33).

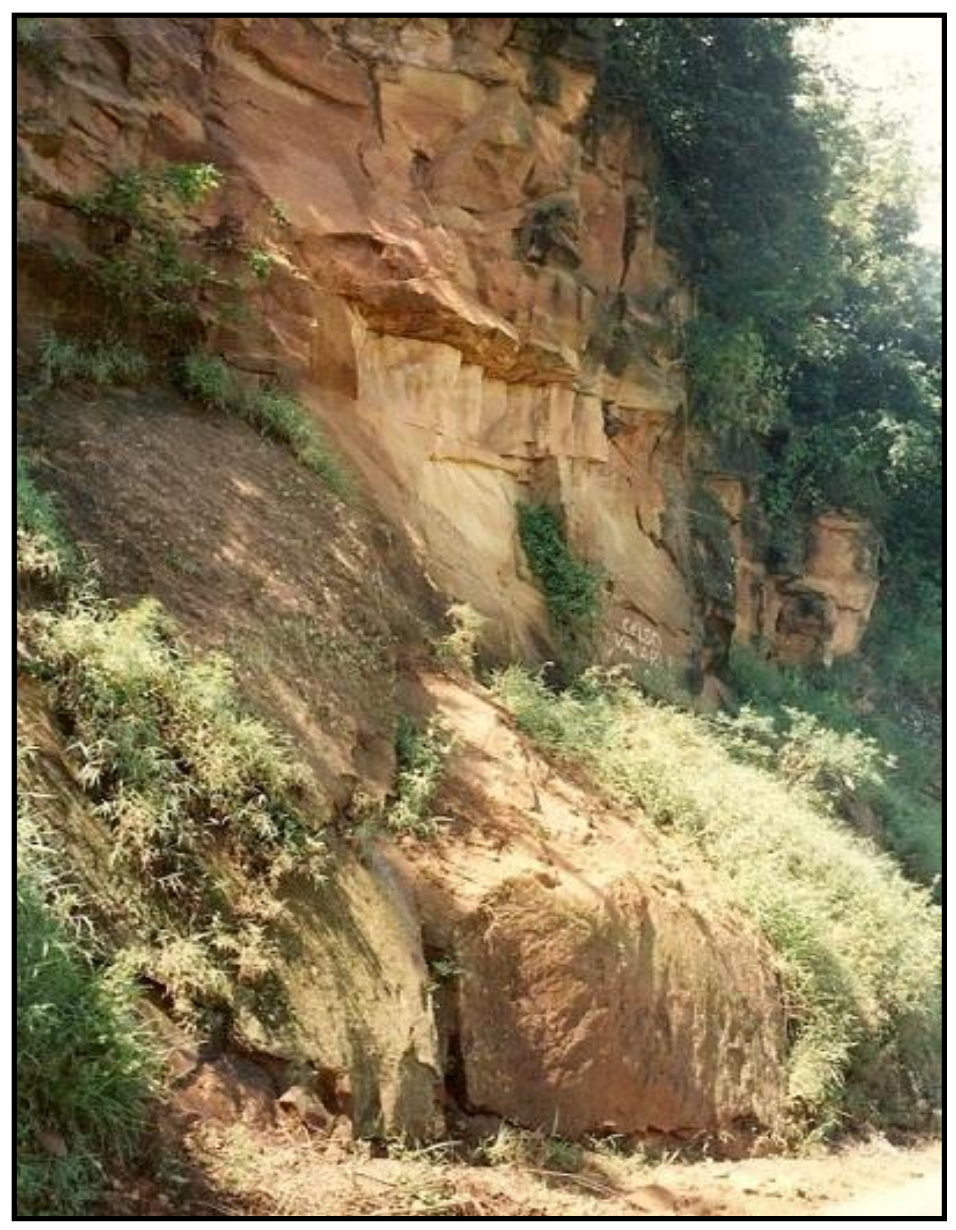

Figura 33 - Arenito silicificado Botucatu. Serra de São Pedro (Pejon, 1992)

c) Formação Serra Geral

Integra os derrames basálticos de natureza variada (ácidos a básicos) que afloram na parte superior da Cuesta Basáltica; possuem granulação fina, textura afanítica e encontram-se associados aos arenitos eólicos da Formação Botucatu.

- Do Grupo Bauru:

Desta unidade a principal formação que ocorre na região de São Pedro e São Carlos é a Formação Itaqueri, composta por arenitos argilosos de coloração marrom-avermelhada e um grupo conglomerático de seixos de basalto e arenito devido aos processos erosivos no contato com a Formação Serra Geral. 
- Dos Sedimentos Cenozóicos:

São provenientes das formações que ocorrem nos seus sítios. No geral, são sedimentos areno-argilosos avermelhados, mal selecionados; formados em ambientes aluvionares e coluvionares; encontrados ora em altitudes elevadas sobre o Arenito Botucatu ( $>900 \mathrm{~m})$, ora na base de encostas.

\subsection{HIDROGEOLOGIA}

De elevada importância do presente estudo, a hidrogeologia regional permite, de forma geral, compreender as características litológicas e estruturais dos solos relacionadas ao processo de infiltração da água nesses solos.

As regiões se inserem na Província Hidrogeológica da Bacia do Paraná, sobre mananciais de água subterrânea como os Aquíferos sedimentares e fraturados: Guarani e Serra Geral, respectivamente (Figura 34).

Enquanto o armazenamento de água ocorre em rochas sedimentares do Guarani (Formações Botucatu e Pirambóia), devido sua alta porosidade, no Serra Geral (derrames basálticos) a água é armazenada ao longo de linhas estruturais (falhas e fraturas), nos horizontes vesiculares e nos interderrames (CETESB, 2008).

Ellert (1980) apud Ferreira (2004), analisando águas subterrâneas da região de São Pedro concluiu que a permeabilidade dos materiais que apresentavam homogeneidade granulométrica superficial, provenientes da Formação Pirambóia, apresentavam uma alta permeabilidade, da ordem de $10-1$ a $10-3 \mathrm{~m} / \mathrm{s}$, ocupando cerca de $80 \%$ da área.

Conforme CETESB (2008), o município de São Carlos apresenta 72\% de sua área no afloramento do Aquífero Botucatu, tendo sua principal área de recarga na porção sul da cidade; na porção norte encontra-se confinado sob os basaltos.
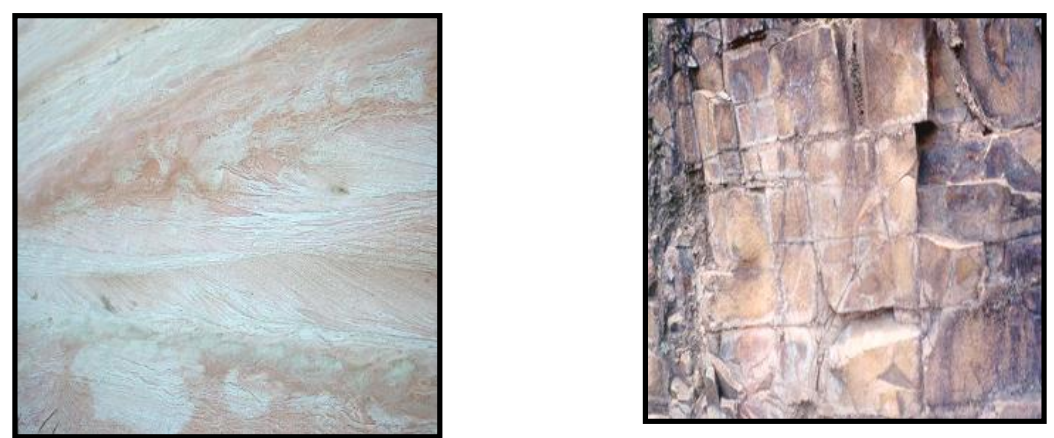

Figura 34 - Aquíferos: sedimentar Guarani e fraturado Serra Geral (CETESB, 2008) 


\section{MATERIAIS E MÉTODOS}

\subsection{FLUXOGRAMA GERAL}

As etapas e metodologias empregadas durante a pesquisa podem ser resumidas no fluxograma abaixo, que contém de forma simplificada os principais métodos adotados para se alcançar os objetivos desse estudo.

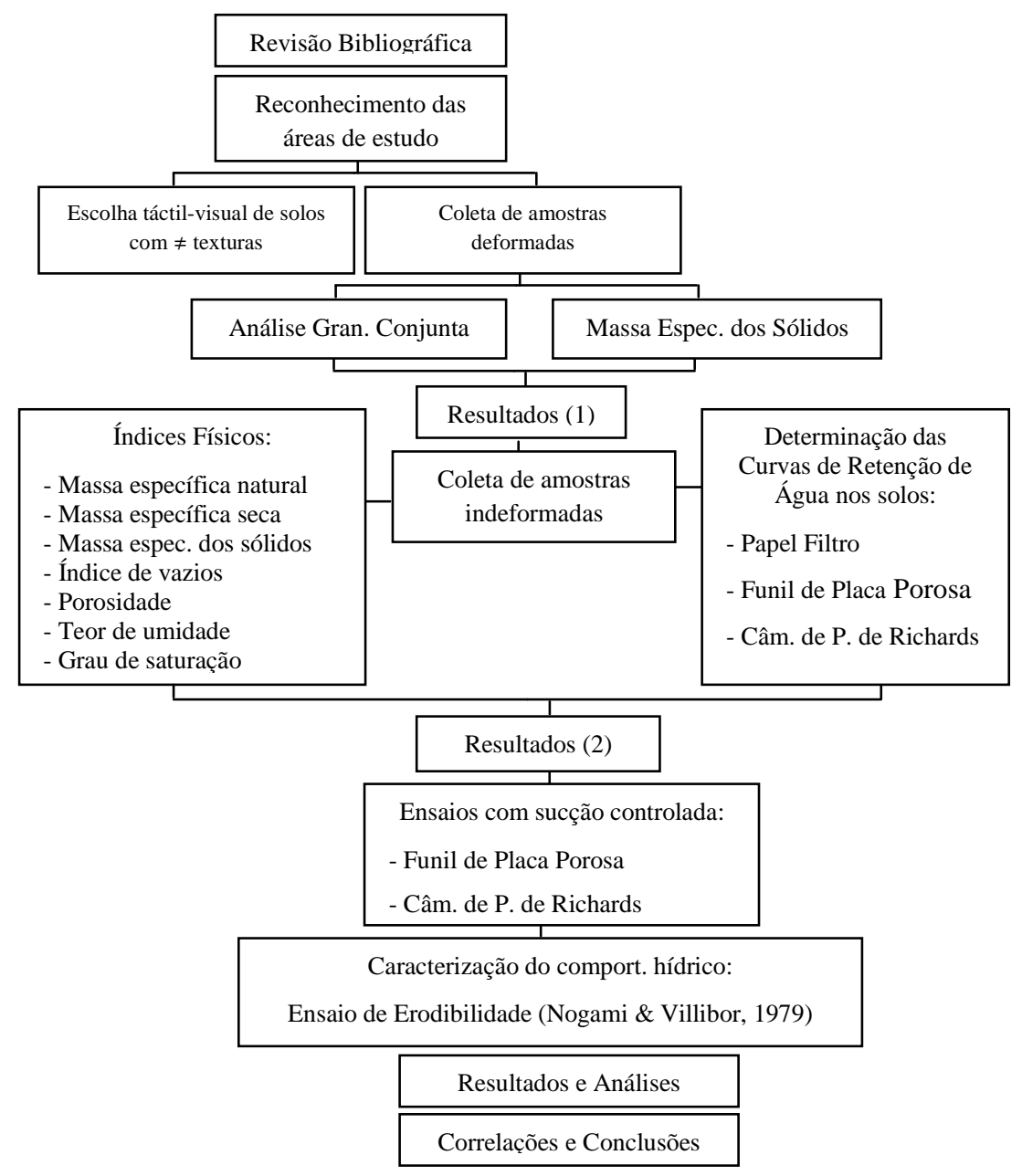

Figura 35 - Fluxograma geral do estudo

\subsubsection{Etapas de Campo}

a) Reconhecimento da área

Inicialmente foi realizada uma visitação a diferentes locais para coleta dos solos de interesse. $\mathrm{Na}$ etapa de reconhecimento fez-se uma rápida análise táctil-visual dos materiais 
encontrados a fim de serem escolhidos tipos de solo com percentagem de grossos e finos diferenciada.

Além da análise visual, as regiões foram selecionadas segundo características já conhecidas baseadas em estudos das potencialidades aos processos erosivos, como mostrado nos trabalhos de Ferreira (2004) e Silva (2003). Deu-se preferência a pontos de coleta com predomínio de feições erosivas devido ao fluxo concentrado de águas superficiais.

b) Coleta e preparação das amostras

A coleta foi efetuada tanto em superfície como em sub-superfície, segundo as técnicas padronizadas e adaptadas para o tipo de material e a finalidade a que se destinou. Recolheram-se dois tipos de amostras: deformadas e indeformadas.

b.1) Amostras deformadas

A amostra de solo deformada deve ser representativa quanto à textura e composição mineral. Amostras deformadas foram caracterizadas através da identificação táctil-visual e por ensaios de classificação segundo prescrições normativas.

Foram coletadas em superfície, tomando-se os devidos cuidados quanto à manutenção do teor de umidade in situ e à presença de matéria orgânica (interferência nos resultados). A partir destas, foram adquiridas amostras reduzidas através de técnicas de quarteamento, em quantidades padronizadas para os ensaios de caracterização.

\section{b.2) Amostras indeformadas}

Foram obtidas amostras em blocos indeformados $(30 \times 30 \times 30) \mathrm{cm}$, representativas do solo quanto à estrutura, teor de umidade, textura e composição mineral, o que permitiu determinar as características físicas do solo in situ, através dos índices físicos e parâmetros hidráulicos.

Durante a coleta das amostras teve-se o cuidado de escolher locais que não apresentassem excesso de matéria orgânica e outros materiais que pudessem alterar significativamente os resultados dos ensaios propostos.

Em sub-superfície, à profundidade de $1 \mathrm{~m}$ da superfície, foram retiradas através de escavação manual (Figura 36), com uso de equipamentos apropriados (caixas metálicas, espátulas, vaselina, enxada, pás, conchas, pincéis, materiais perfuto-cortantes, etc.). A partir dos blocos foram moldadas amostras indeformadas reduzidas com dimensões padronizadas para a realização dos ensaios com sucção controlada e de erodibilidade. 

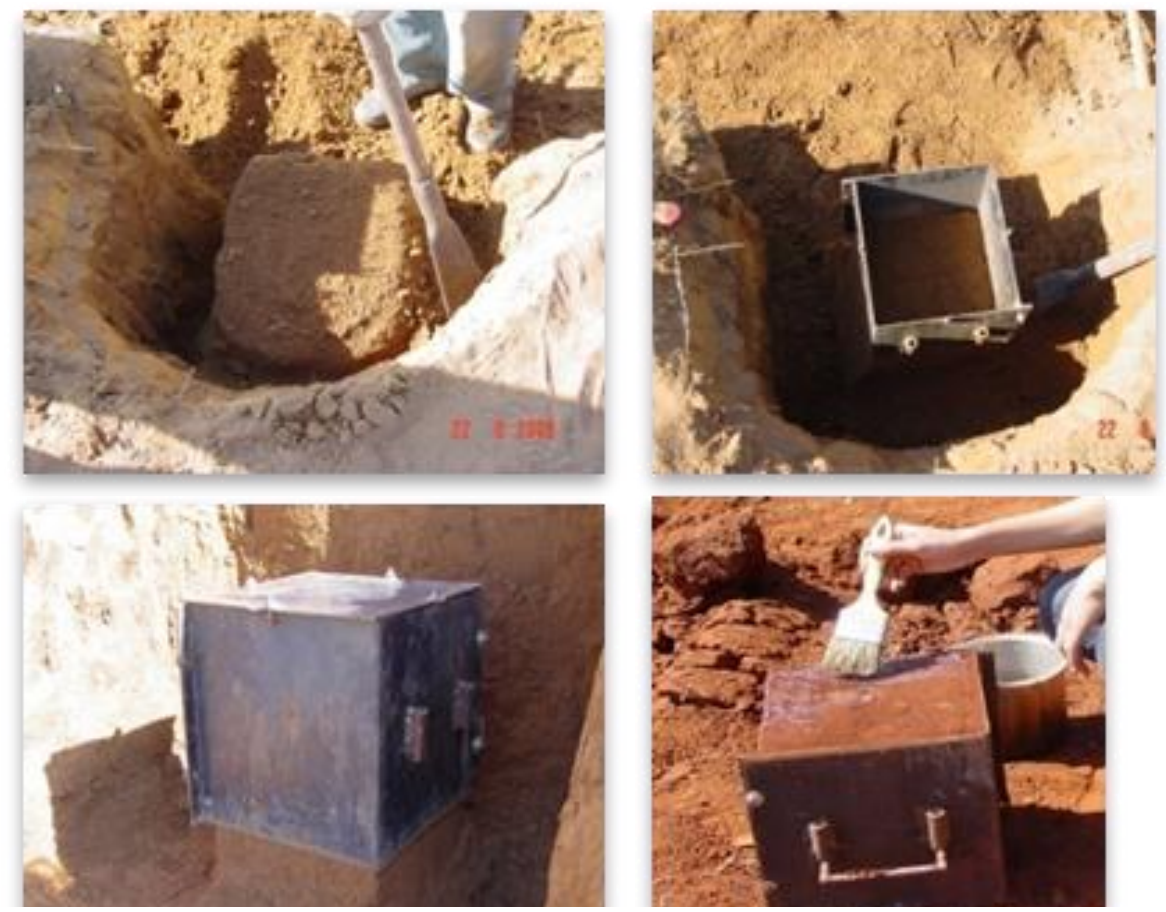

Figura 36 - Coleta de amostra indeformada (escavação e selamento)

\section{b.3) Regiões}

Na região de São Carlos, os pontos de coletas das amostras deformadas e dos blocos se situam em locais diferentes no município, um mais próximo ao centro comercial da cidade e outro na periferia da cidade.

A primeira área de coleta ocorreu no campo experimental da USP (Campus 2), no bairro de Santa Felícia, representada por taludes de corte da região (Figura 37), com coordenadas UTM 0197512/7564732 NW e altitude de $843 \mathrm{~m}$.
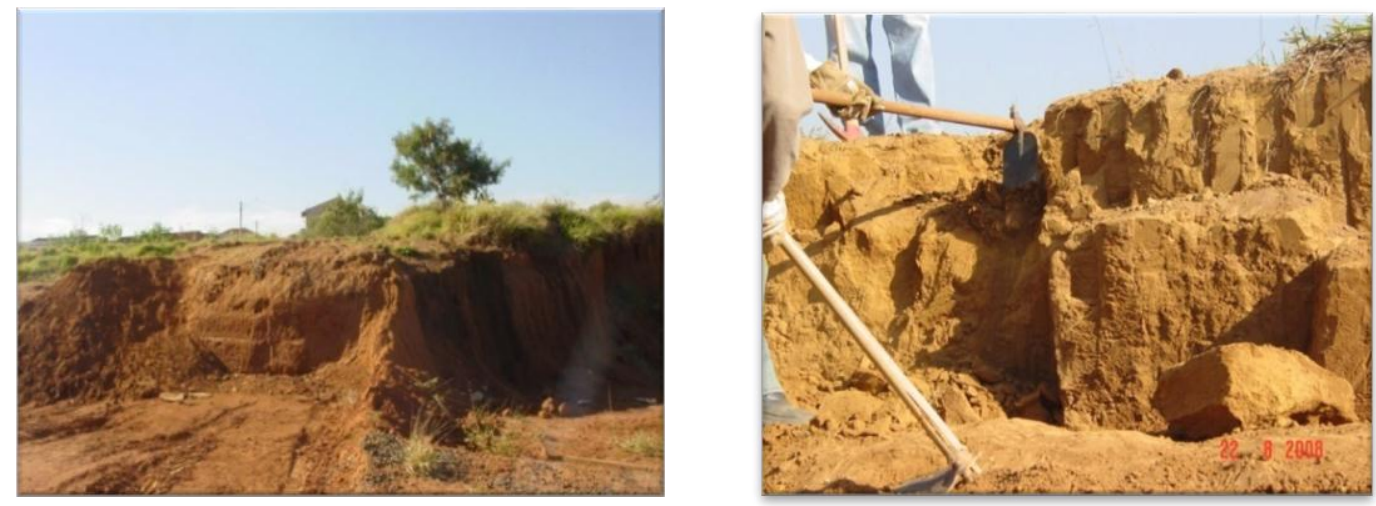

Figura 37 - Ponto de coleta Campus 2 (Solo 1) 
A segunda área foi locada em taludes de corte às margens da avenida comendador Alfredo Maffei, próxima ao Córrego do Gregório, no centro (Figura 38), com coordenadas UMT 0202466/7561720 NE, altitude de $824 \mathrm{~m}$.
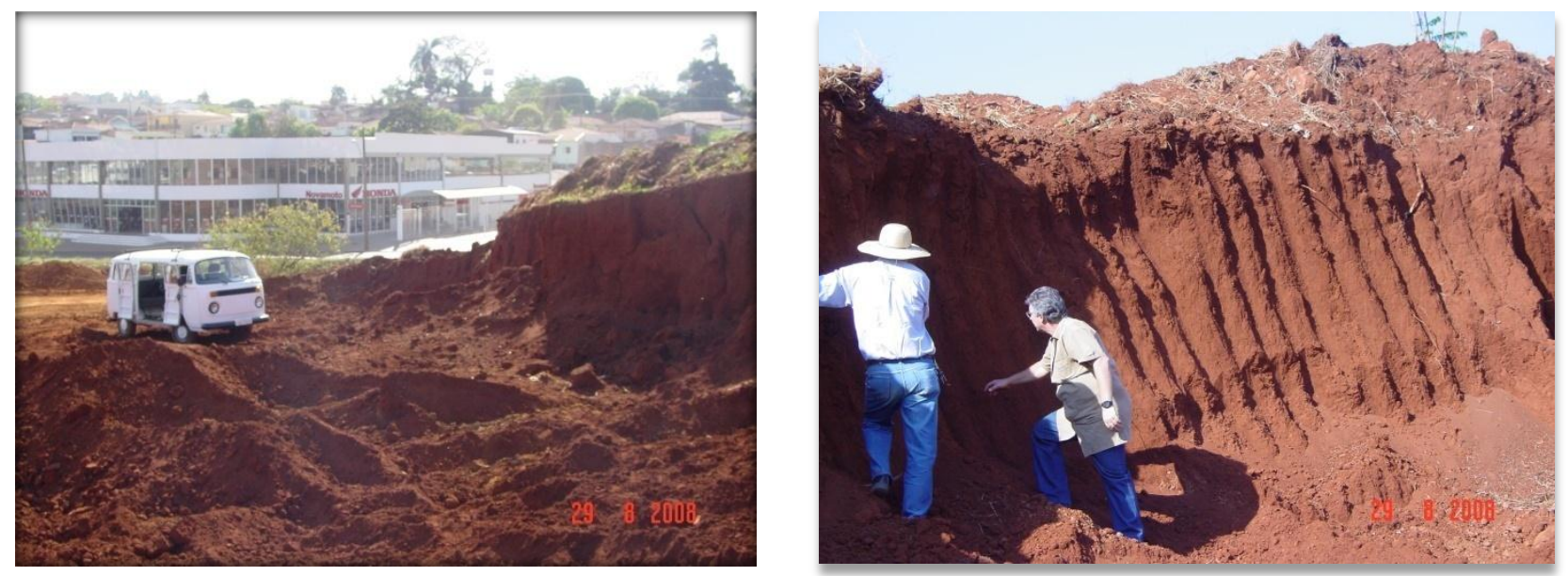

Figura 38 - Ponto de coleta Facchina (Solo 2)

Na região de São Pedro, as amostras deformadas e os blocos de amostra indeformada foram retirados às margens da rodovia SP-304, em Santa Maria da Serra (Figura 39), tendo coordenadas UTM 793223 E e $7500545 \mathrm{~N}$, altitude de $512 \mathrm{~m}$.

Por distarem cerca de 100 km do município de São Carlos, região de concentração da pesquisa laboratorial, as amostras foram devidamente revestidas com tela e parafina para evitar maior perturbação do bloco e perdas excessivas de umidade. Os blocos amostrais foram retirados no interior de uma voçoroca local (Figura 39 e Figura 40). Após o transporte, foram armazenados em câmara úmida, de forma a manter o teor de umidade de campo.
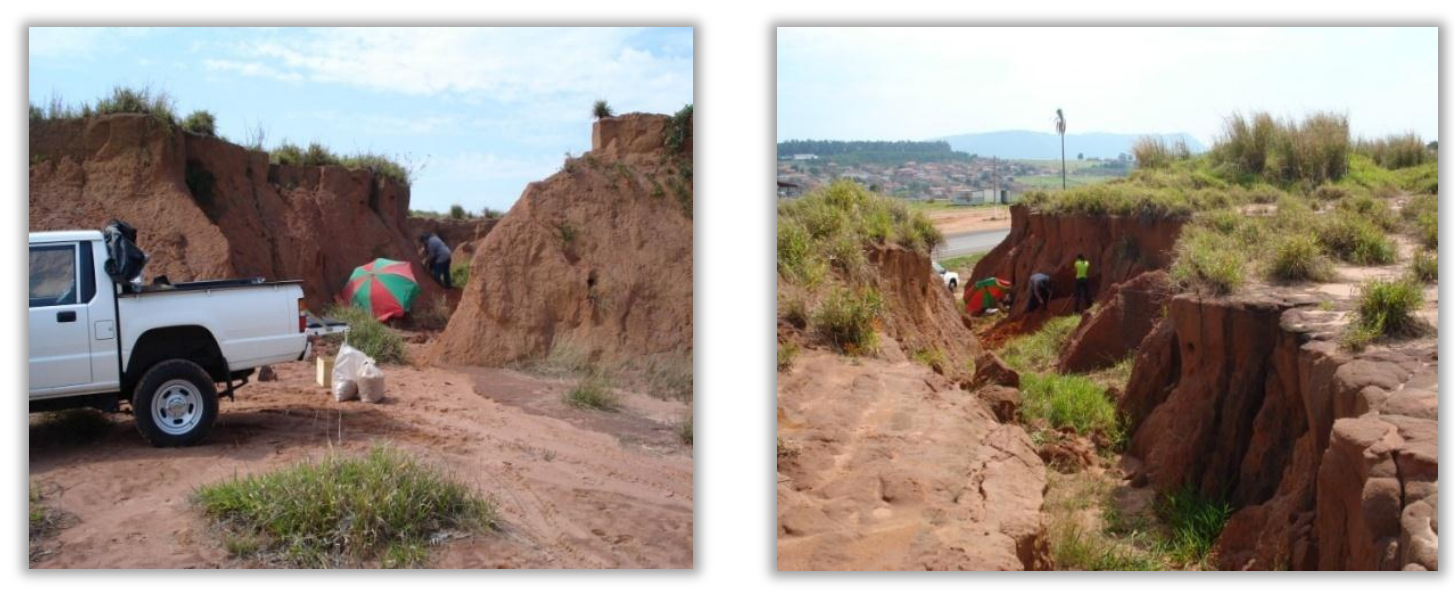

Figura 39 - Ponto de coleta S.Pedro (Solo 3) 

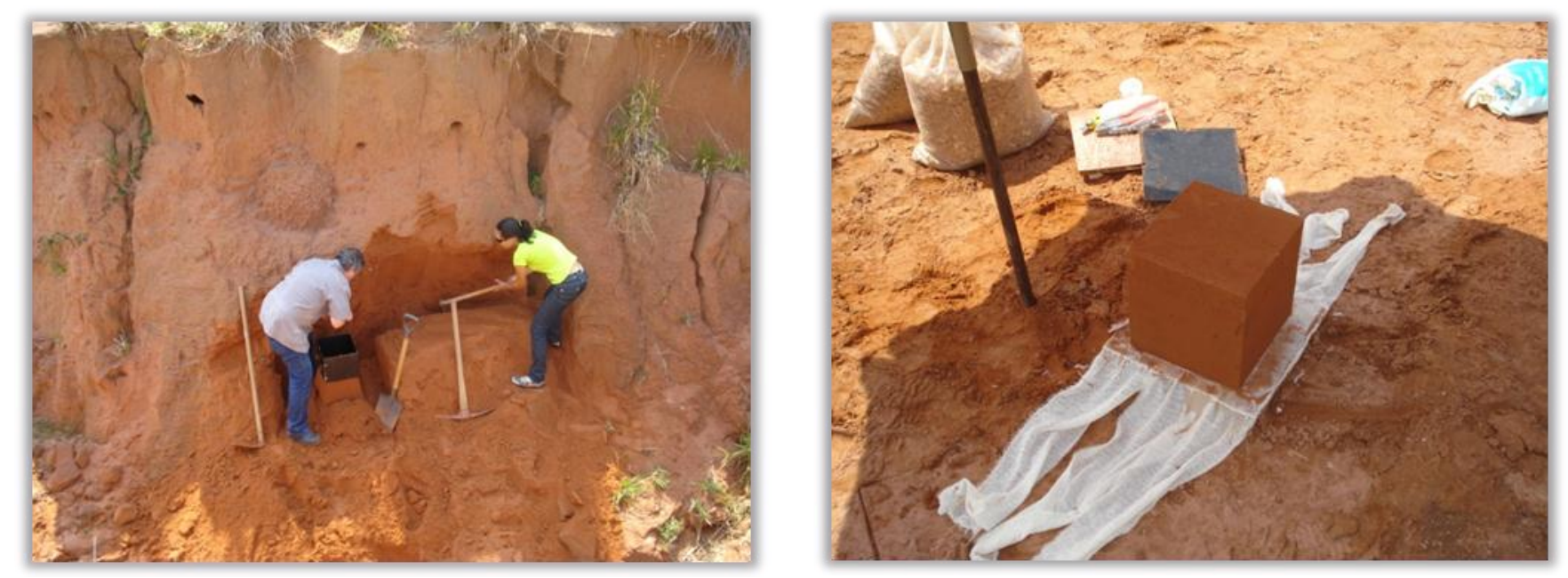

Figura 40 - Amostragem no interior de uma voçoroca (Solo 3)

\subsubsection{Ensaios Laboratoriais}

Para conhecimento das características e comportamento dos solos coletados, foram testadas amostras deformadas através dos ensaios de caracterização, e amostras indeformadas nos ensaios de curvas de retenção de água no solo e de erodibilidade.

\subsubsection{Ensaios de caracterização}

Para a classificação e identificação dos materiais inconsolidados, a pesquisa se ateve aos ensaios de caracterização mais corriqueiros em Mecânica dos Solos, como a Análise Granulométrica Conjunta (NBR 7181/84) e a Massa Específica dos Sólidos (NBR 6508/84). Os Índices Físicos como teor de umidade $(w)$ e massa específica $(\rho)$ foram determinados experimentalmente e os demais $\left(e, n, S r, \rho_{d}\right)$ através de correlações entre índices. Isso se deveu à intenção deste trabalho de promover a estimativa do potencial matricial dos solos a partir de medidas indiretas e por correlações entre índices físicos, permitindo desta forma a equiparação com outros solos.

\subsubsection{Ensaios de laboratório para determinação das Curvas de Retenção de Água}

As curvas de retenção de água dos solos foram obtidas sob trajetórias de secagem, através dos métodos do Papel Filtro, Funil de Placa Porosa e Câmara de Pressão de Richards. 
Os ensaios com sucção controlada (Funil e Câmara) também foram utilizados para imposição de sucção em corpos-de-prova usados no ensaio de absorção.

\section{a) Método do Papel Filtro}

O ensaio foi realizado consoante metodologia proposta por Marinho (1995). Por se tratar de um método indireto para determinar a sucção, foram utilizadas equações como curvas de calibração do papel filtro usado. A sucção matricial foi calculada a partir dos teores de umidade finais do solo e do papel filtro.

Resumidamente, a sequência do ensaio é mostrada na Figura 41, onde os corpos de prova $(10$ x 50$) \mathrm{mm}$ usados foram previamente saturados por capilaridade $(24 \mathrm{~h}$ para os arenosos e 48h para os argilosos) e submetidos ao efeito da secagem ao ar até atingirem os parâmetros de secagem (massa ideal) pré estabelecidos ao contato com o papel Whatman $\mathrm{n}^{\circ}$ 42. O papel filtro encontrou-se em pleno contato com o solo de forma que a medida da sucção obtida equivalesse somente à matricial.

Após o conjunto ser hermeticamente fechado, foi deixado ao tempo de equilíbrio de 7 a 10 dias. Após este período, procedeu-se o cálculo de umidade dos papéis-filtro, umidade do solo e conseqüente sucção matricial através das equações de Chandler (1992):

$$
\begin{aligned}
& \operatorname{Sucção~}(k P a)=10^{\left(6,05-2,48 \cdot \log W_{\text {papel }}\right)}>47 \% \\
& \operatorname{Sucção}(k P a)=10^{\left(4,84-0,0622 \log W_{\text {papel }}\right)} \leq 47 \%
\end{aligned}
$$

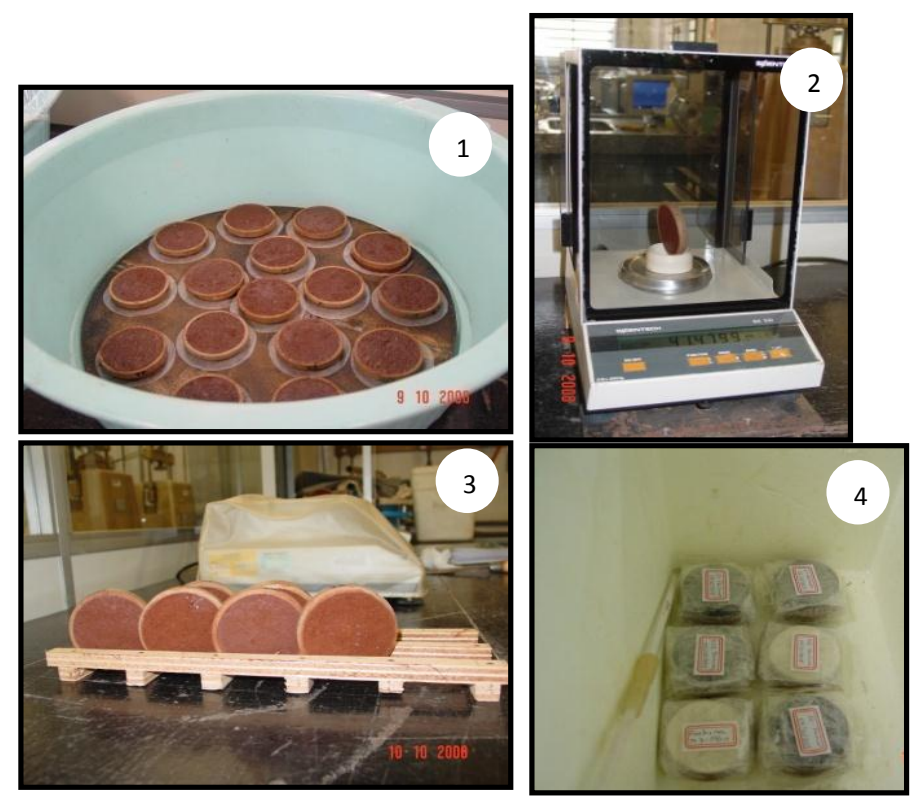

Figura 41 - Sequência do ensaio de Papel Filtro 
- Equipamentos

Os materiais utilizados para o ensaio foram: (1) balança eletrônica com precisão de 0,0001g; (2) reservatório plástico para transporte de papel filtro seco; (3) tesoura; (4) espátula; (5) pincel; (6) pinça metálica para remoção do papel filtro; (7) fita adesiva; (8) papel filtro Whatman $\mathrm{n}^{\circ} 42$; (9) luva de borracha; (10) filme plástico; (11) etiquetas; (12) disco de PVC; (13) anéis de moldagem.

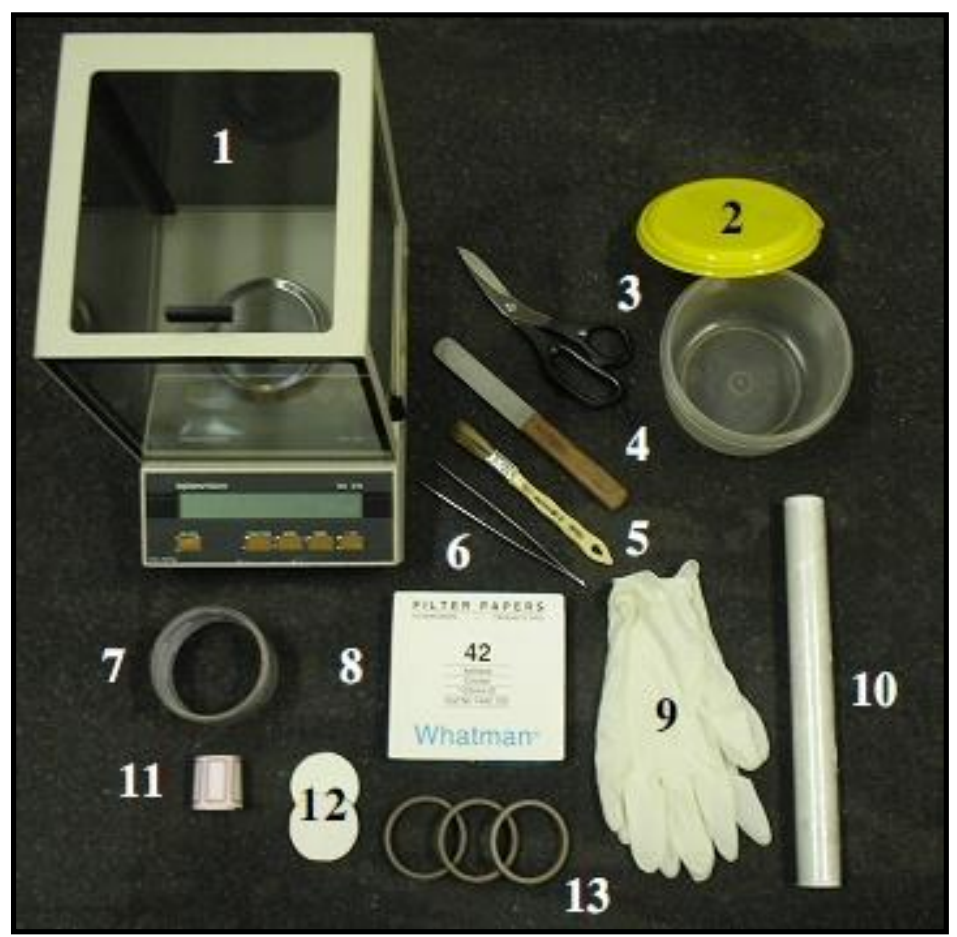

Figura 42 - Equipamentos usados no Método do Papel Filtro (Rodrigues, 2007)

- Procedimentos detalhados

1) Moldagem das amostras indeformadas reduzidas:

Dos blocos amostrais indeformados foram moldados 16 corpos de prova $(10$ x 50) $\mathrm{mm}$ para cada tipo de solo, sendo que 15 anéis foram destinados ao ensaio e 1 para determinação da umidade de saturação. Foram usados anéis de PVC, com dimensões conhecidas (massa e volume). Moldagem segundo mostrado na Figura 43.

Logo após a moldagem dos corpos de prova (anel + amostra) foram determinados a massa do conjunto e o teor de umidade de moldagem, com auxílio de no mínimo 3 cápsulas 
metálicas. Esses dados iniciais foram necessários para determinação dos índices físicos da amostra.

Quando não foi possível a moldagem de todos os corpos de prova no mesmo dia, novos teores de umidade de moldagem foram calculados. Logo após, os corpos de prova foram alocados numa bacia contendo pedra porosa saturada semi-submersa em água destilada para saturação das amostras.
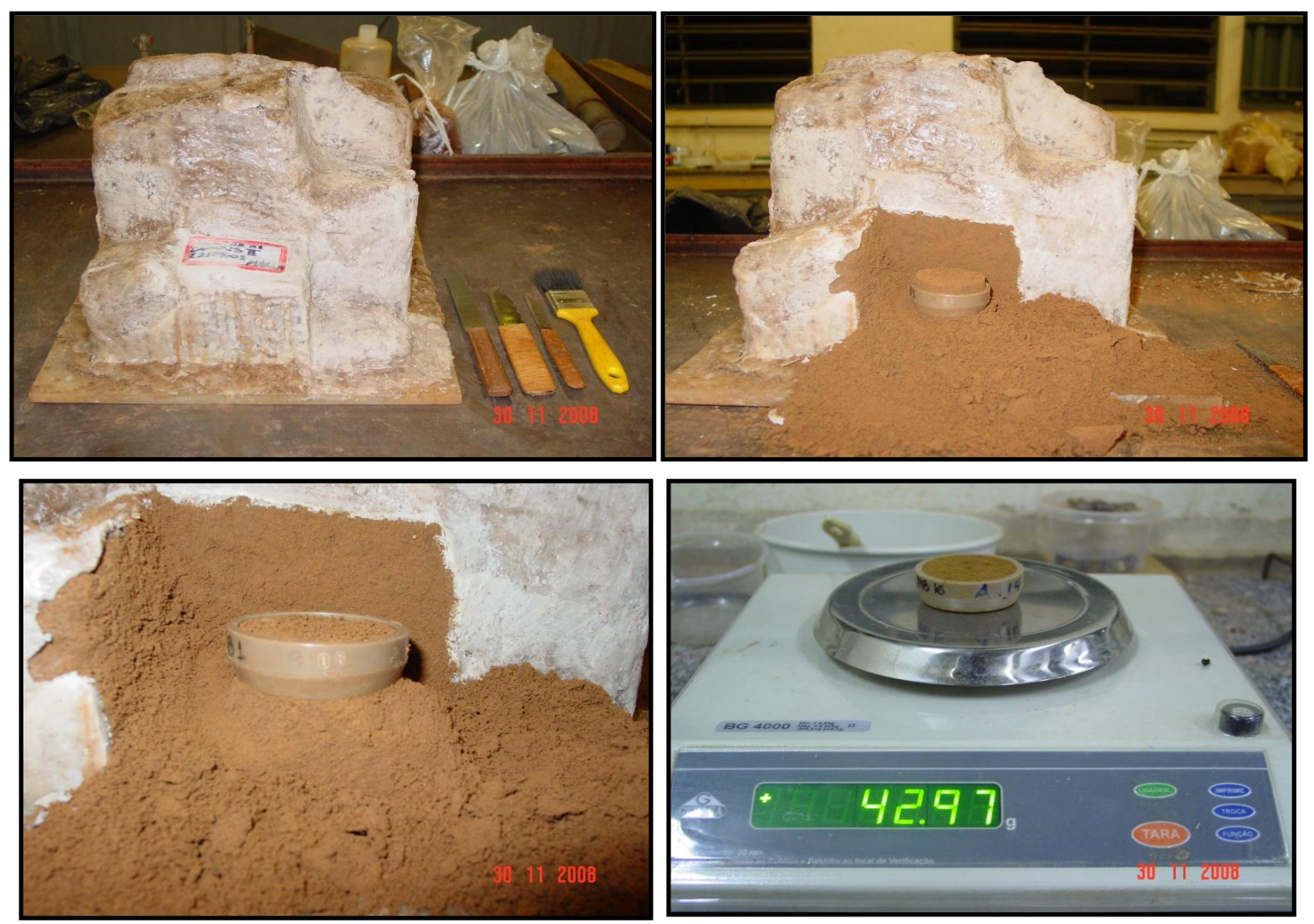

Figura 43 - Sequência de Moldagem e pesagem dos corpos de prova

2) Saturação das amostras

Cada amostra foi colocada sobre um papel filtro comum distribuído sobre uma placa porosa saturada com água destilada. Uma aba do papel fez contato com a água que teve altura máxima até metade da placa porosa. As amostras sofreram saturação por capilaridade; procedimento este que objetivou a expulsão de bolhas de ar, como mostrado na Figura 41.

Os recipientes foram cobertos com filme plástico a fim de evitar a evaporação da água. Os solos arenosos necessitaram de $24 \mathrm{~h}$ de saturação, enquanto as amostras argilosas, um 
período maior de tempo, em média 48 h de saturação. Após saturação, todos os corpos de prova foram pesados em balança com precisão de $0,0001 \mathrm{~g}$.

\section{3) Montagem do ensaio}

Toda a manipulação do papel filtro foi feita sobre uma superfície limpa, desinfetada com álcool, utilizando luvas cirúrgicas e pinça para evitar a contaminação do papel por resíduos. O ensaio foi realizado em sala com temperatura controlada para evitar variações de umidade.

Para o ensaio, o papel filtro utilizado foi o tipo Whatman $\mathrm{N}^{\circ} 42$, na condição "seco ao ar", retirado diretamente da caixa. Quando não era utilizado, o papel foi mantido dentro da caixa ou em sacos plásticos selados após ser manipulado.

Usaram-se dois papeis filtro por amostra, um para cada lado do solo, recortados em tamanho um pouco menor que o diâmetro da amostra a fim de que o contato com o solo fosse total. Os papéis foram diferenciados através de marcas, furos e cortes para facilitar depois os procedimentos de cálculo do teor de umidade dos papéis.

Após a saturação das amostras e obtidos os índices físicos e as massas finais (parâmetros de secagem), iniciou-se o procedimento de secagem das amostras até o teor de umidade desejado, desde a amostra com saturação de $100 \%$ à menos úmida. Para tanto as amostras foram secas ao ar na posição vertical, até que por evaporação fosse obtida a massa final desejada referente ao teor de umidade final almejado. Quando se obteve os valores requeridos, o conjunto papéis-filtro e amostra foram embalados em filme plástico e vedados com fitas para serem acondicionados em recipiente isolante, até que o equilíbrio fosse atingido.

4) Procedimentos de cálculo

Após o período de equilíbrio entre papel filtro e amostra de solo e com base em todos os índices físicos calculados, bem como as massas finais desejadas, procedeu-se o cálculo de umidade dos papéis-filtro, umidade do solo e conseqüente sucção matricial, conforme as equações de Chandler, já mencionadas. O teor de umidade no papel e no solo foi obtido pelas formulações abaixo:

$$
W_{\text {papel }}(\%)=\frac{\text { Massa }_{\text {umida }}-\text { Massa }_{\mathrm{sec} a}}{\text { Massa }_{\mathrm{sec} a}} .100
$$




$$
W_{\text {solo }}(\%)=\frac{\text { Massa }_{\text {agua }}}{M a s s a_{\text {sólidos }}} .100
$$

De posse dos pares de teor de umidade do solo e sucção referente, foram obtidas as curvas de retenção de água utilizando o programa SWRC (Soil Water Retention Curve) com parâmetros de curva ajustados, baseado em arquivo de entrada de dados.

\section{b) Método do Funil de Placa Porosa}

Também conhecido como Funil de Haines, este equipamento consiste num funil com uma placa porosa de alto valor de entrada de ar, hidraulicamente conectada a um tubo flexível acoplado a um reservatório de altura regulável para saída da água, quando o procedimento é a secagem da amostra.

Nessa técnica, a sucção foi pré-estabelecida conforme a altura do reservatório posicionado em cota inferior ao nível da amostra saturada (Figura 44). A sucção $\left(u_{a}-u_{w}\right)$ equivaleu a altura da coluna d'água acima do nível do reservatório, negativa em relação à cota do solo ensaiado, sendo representada pela fórmula (9):

$$
u_{a}-u_{w}=g \cdot\left(z_{A}-z_{B}\right)
$$

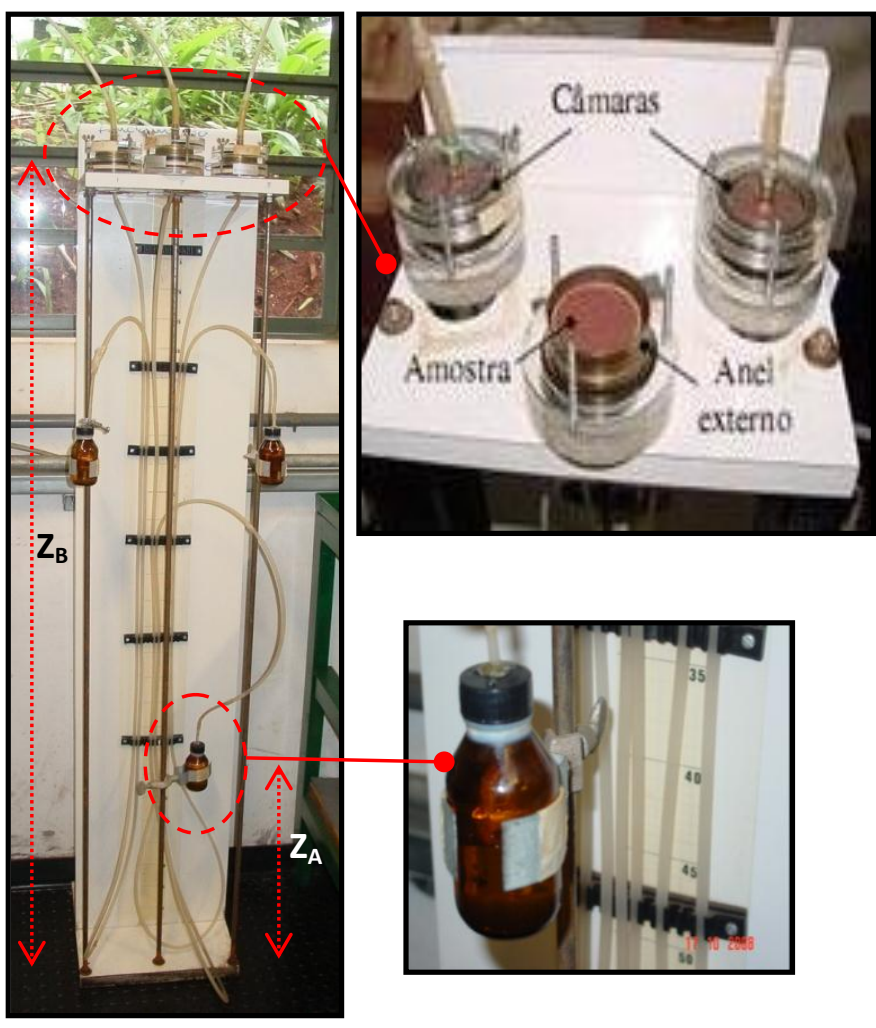

Figura 44 - Funil de Placa Porosa (EESC-USP) 
O equipamento utilizado tem altura máxima de 1,40m, permitindo imposição máxima de $14 \mathrm{kPa}$, e três compartimentos amostrais a serem utilizados por vez. Foram ensaiadas 03 (três) amostras (16 x 40)mm de cada solo para cada sucção imposta. Usaram-se imposições de 2, 3, 5, 8, 12 e $13 \mathrm{kPa}$, definidas para detalhar melhor o trecho inicial das curvas características. O procedimento do ensaio seguiu a seguinte sequência para cada sucção:

- o sistema foi inicialmente saturado com água destilada para evitar bolhas de ar no tubo e permitir a continuidade da fase líquida;

- as amostras previamente saturadas foram dispostas sobre as placas porosas também saturadas, e o conjunto foi fixado por anel metálico e protegido pela câmara externa;

- o reservatório de água foi então rebaixado até a altura de interesse, permitindo a dessaturação do solo até que cessasse o fluxo de água;

- após o equilíbrio, as amostras foram retiradas para pesagem, e posterior determinação do teor de umidade gravimétrico.

\section{c) Câmara de Pressão de Richards}

A técnica emprega o princípio da translação de eixos, com incrementos de pressão de ar aplicados para expulsar a água dos poros do solo. A água do sistema fica submetida à pressão atmosférica e por isso a pressão da água $\left(u_{w}\right)$ durante o ensaio é igual a zero; a sucção $\left(u_{a}-u_{w}\right)$ induzida então é igual à pressão de ar inicial. Apenas é possível garantir que a sucção do solo é igual à pressão de ar aplicada após o equilíbrio do sistema, quando cessa o fluxo de água das amostras.

Nesse ensaio, inicialmente, as placas porosas de alta pressão de entrada de ar foram dispostas em recipientes com água destilada e deaerada para saturarem por um período de no mínimo 24h. Após a saturação, as amostras $(20$ x 40)mm previamente também saturadas, foram distribuídas sobre a placa a fim de evitar descontinuidade da fase líquida (Figura 45). Todo o sistema foi saturado, incluindo os tubos de saída da panela. A Câmara foi hidraulicamente conectada a um mini-reservatório por um tubo flexível, estando em contato com a atmosfera por um orifício lateral.

Usaram-se duas panelas de pressão, uma para sucções até $500 \mathrm{kPa}$ e outra para sucções maiores, até no máximo $1500 \mathrm{kPa}$. O ensaio foi conduzido com incrementos de pressão de ar no interior da panela com o intuito de drenar a água contida nos corpos-deprova. Foram impostas pressões de 10, 20, 50, 100, 200, 500 e $800 \mathrm{kPa}$. 
Cada valor de pressão foi aplicada a um conjunto de amostras até se observar interrupção do fluxo de água inicial. Esta interrupção não foi considerada como o equilíbrio do sistema visto que os três tipos de solo estavam dentro da câmara, e cada um teria um tempo de equilíbrio diferente.

Desta forma, o critério de interrupção do ensaio foi a constância de massa verificada por meio da pesagem dos corpos-de-prova em balança de precisão de 0,0001g. Cessada a variação de massa, retiraram-se as amostras para cálculo dos teores de umidade correspondentes a sucção aplicada. De acordo com os pares sucção-umidade foram obtidas as curvas de retenção de água.

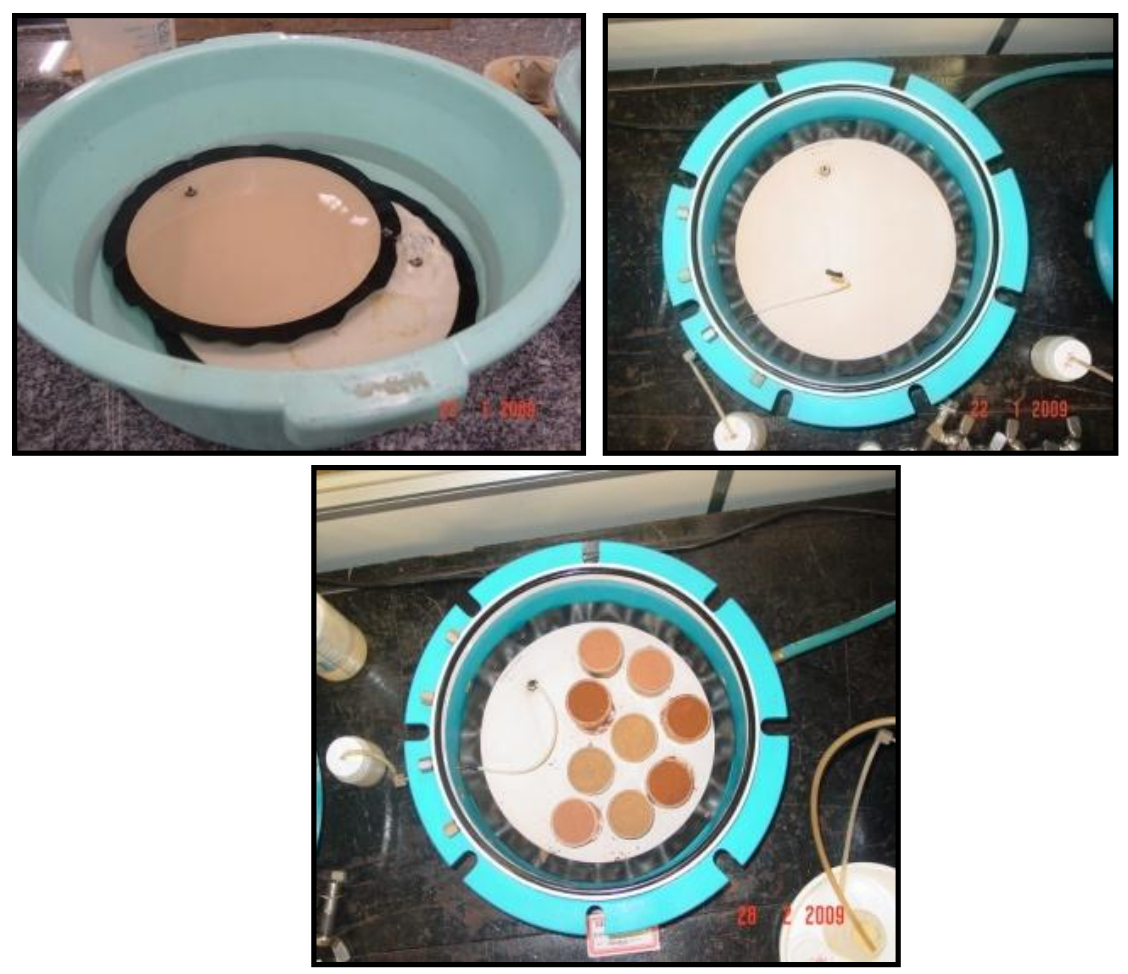

Figura 45 - Sequência do ensaio (saturação; montagem do equipamento; amostras sobre a placa)

Os incrementos de pressão da Câmara de Pressão de Richards foram determinados segundo a análise dos resultados para cada solo em estudo, de acordo com o traçado da curva de retenção de água obtida pelas técnicas do Papel Filtro e Funil de Placa Porosa. Foram 
escolhidas faixas de sucção de modo a complementar os intervalos das curvas com ausência de pares sucção-umidade.

Após o equilíbrio do sistema para cada incremento de pressão adotado, as amostras foram devidamente pesadas em balança com precisão de 0,0001g e logo em seguida submetidas ao Ensaio de Erodibilidade, sendo que pelo menos 01 (uma) foi usada para cálculo experimental do teor de umidade (constância de massa em estufa).

Foi observado que os tempos de equilíbrio para cada tipo de solo são diferentes, visto a caracterização de cada um, e conhecendo-se seus índices físicos (porosidade, índice de vazios e outros), é possível ter uma média de tempo de estabilização para solos arenosos (estabilização mais rápida) e solos argilosos (estabilização mais demorada).

A Câmara de Pressão de Richards também foi utilizada para preparar as amostras quanto ao Ensaio de Absorção D’Água. O equipamento foi escolhido para este fim por ser hermeticamente fechado e não permitir variações no teor de umidade das amostras. Além disso, as amostras do mesmo material apresentariam menor dispersão quando aos resultados de absorção de água devido à homogeneidade na imposição da sucção.

\subsubsection{Ensaios de caracterização do comportamento hídrico}

\section{a) Ensaio de Erodibilidade (Nogami \& Villibor, 1979)}

Foi realizado para se determinar a suscetibilidade dos diferentes tipos de solo aos processos erosivos, através do potencial de absorção de água pela amostra e sua perda de massa quando submersa em água por um período de $24 \mathrm{~h}$.

Neste trabalho, utilizaram-se amostras indeformadas secas ao ar e na sombra por um período de sete dias, ao menos. Por este procedimento dificultar o controle do teor de umidade, corpos de prova foram ensaiados na Panela de Richards e Funil de Placa Porosa, segundo faixas de sucção mais apropriadas a cada método.

Pelo menos 03 (três) amostras de cada solo se submeteram a cada técnica, sendo que, ao atingirem o equilíbrio para cada sucção imposta, 02 (duas) foram testadas no ensaio de erodibilidade, e 01 (uma) usada para cálculo do teor de umidade após estufa.

Tomaram-se os devidos cuidados no momento do manuseio das amostras retiradas dos equipamentos em direção ao ensaio de absorção, a fim de que estas não perdessem massa de sólidos, o que adulteraria os cálculos finais bem como as correlações propostas. Logo mais, 
seguem os procedimentos para cada etapa deste ensaio: absorção de água; perda de massa por imersão.

\section{a.1.) Ensaio de Absorção de Água}

Primeiro, o equipamento de absorção foi calibrado, nivelado e saturado com água destilada, a fim de que a água dentro do reservatório aflorasse na pedra porosa saturada, mantendo-a dessa forma. Isso permitiu que um filme de água sobre a pedra porosa garantisse um perfeito contato com a amostra de umidade conhecida, e o volume de água fosse quantificado sem falseamentos.

Foi observado o menisco formado no interior do tubo, para que tangenciasse o ínicio da régua de medida. Iniciou-se o ensaio através da contagem de tempo, marcando de 5 em 5 segundos o volume água absorvido pela área do corpo de prova, representado por $q$ $\left(\mathrm{cm}^{3} / \mathrm{cm}^{2}\right)$.

O ensaio terminou ao se perceber a mancha de água formada no topo da amostra, e o cessar do movimento menisco no tubo. Logo depois, pesaram-se as amostras. De posse dos dados lineares de volume e tempo de absorção, plotaram-se curvas $q \times t^{0,5}$ cujo coeficiente angular da reta representa o índice de absorção de água $\left(I_{a b s}\right)$, parâmetro objeto das correlações propostas.

\section{a.2.) Ensaio de Perda de Massa por Imersão}

Foi realizado logo após o ensaio de absorção de água, conforme descrito anteriormente, calculando-se o percentual de massa seca perdida em relação à inicial $(P)$. A sequência da montagem segue na Figura 46 e Figura 47.
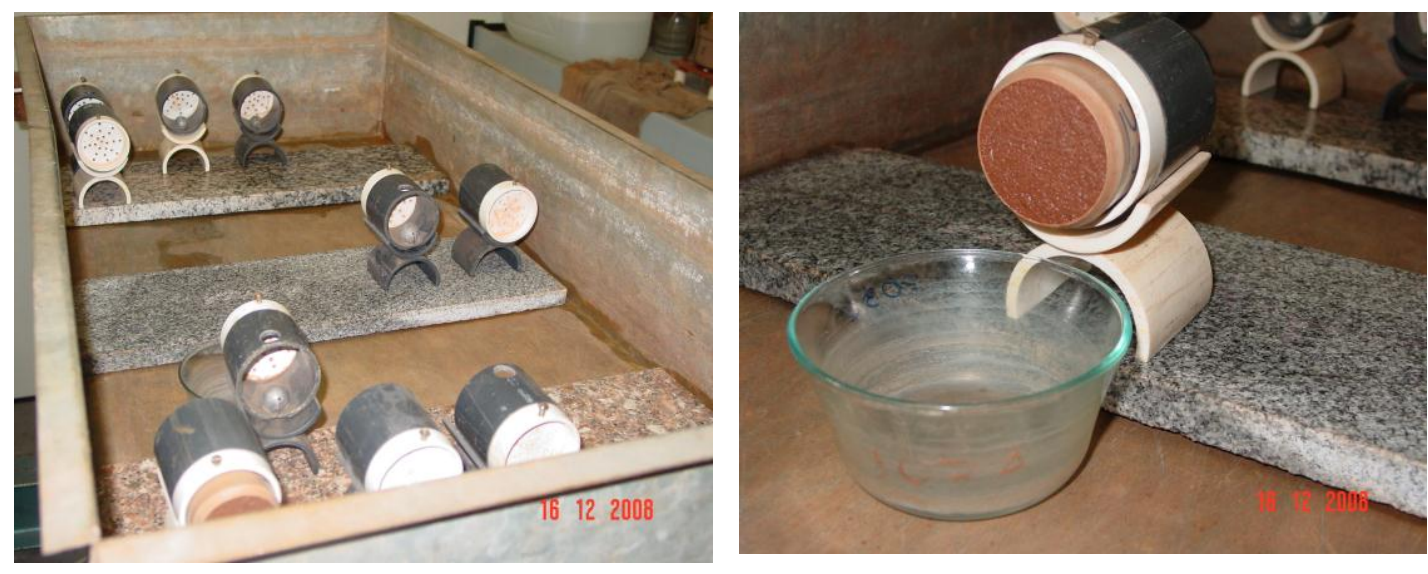

Figura 46 - Montagem do ensaio de perda de massa 

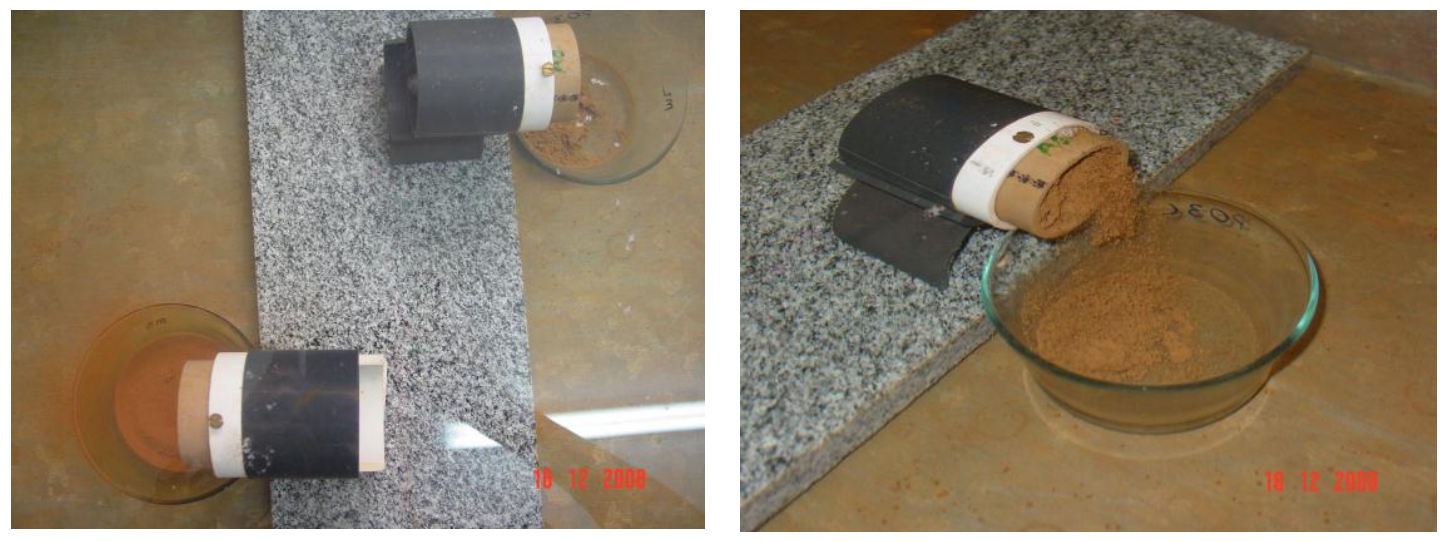

Figura 47 - Coleta do solo despreendido no ensaio de perda de massa

Através dos parâmetros $I_{a b s}$ e $P$ foi possível determinar o índice de erodibilidade $(E)$, segundo as formulações propostas pelos autores (10) e modificadas por Pejon (1992) (11).

$$
\begin{gathered}
E_{40}=40 \cdot \frac{I_{a b s}}{P} \\
E_{52}=52 \cdot \frac{I_{a b s}}{P}
\end{gathered}
$$

\section{RESULTADOS E ANÁLISES}

\subsection{ENSAIOS DE CARACTERIZAÇÃO}

Os resultados dos ensaios de caracterização seguem resumidos da Tabela 5. Do ensaio de granulometria conjunta foram plotadas curvas granulométricas para cada solo (Figura 48, Figura 49 e Figura 50) e a classificação granulométrica foi segundo a NBR 6502/95. Os valores da massa específica dos sólidos $\left(\rho_{s}\right)$ foram obtidos segundo o ensaio normatizado.

Tabela 5 - Classificação granulométrica NBR 6502/95

\begin{tabular}{cccccc}
\hline Solo & Local & $\begin{array}{c}\text { Areia } \\
(\%)\end{array}$ & $\begin{array}{c}\text { Silte } \\
(\%)\end{array}$ & $\begin{array}{c}\text { Argila } \\
(\%)\end{array}$ & $\begin{array}{c}\rho_{\mathrm{s}} \\
\left(\mathrm{g} / \mathrm{cm}^{3}\right)\end{array}$ \\
\hline 1 & Campus 2 & 59 & 6 & 35 & 2,73 \\
2 & Facchina & 26 & 30 & 44 & 2,95 \\
3 & São Pedro & 84 & 3 & 13 & 2,63 \\
\hline
\end{tabular}




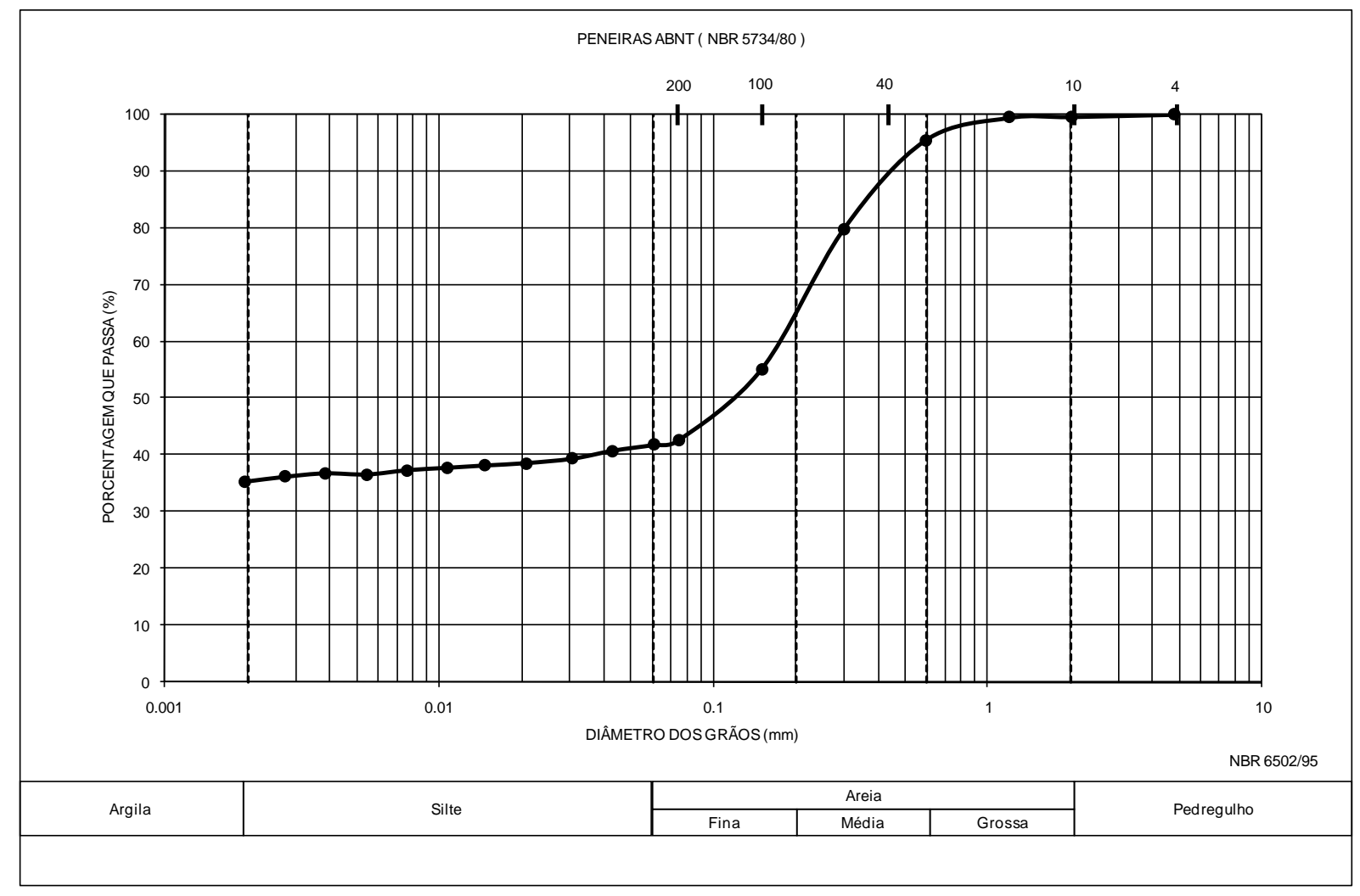

Figura 48 - Curva Granulométrica do Solo 1 (Campus 2)

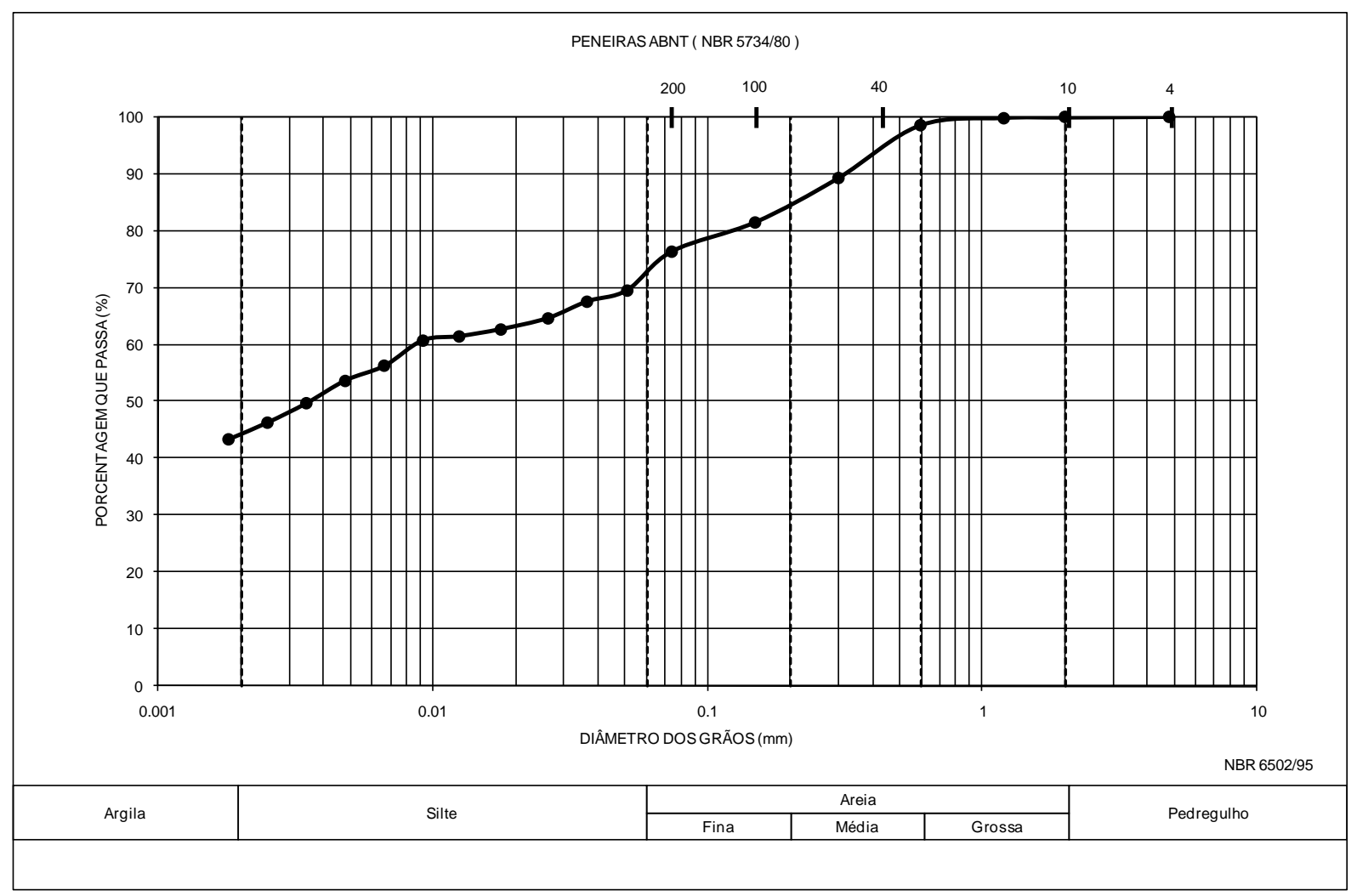

Figura 49 - Curva Granulométrica do Solo 2 (Facchina) 


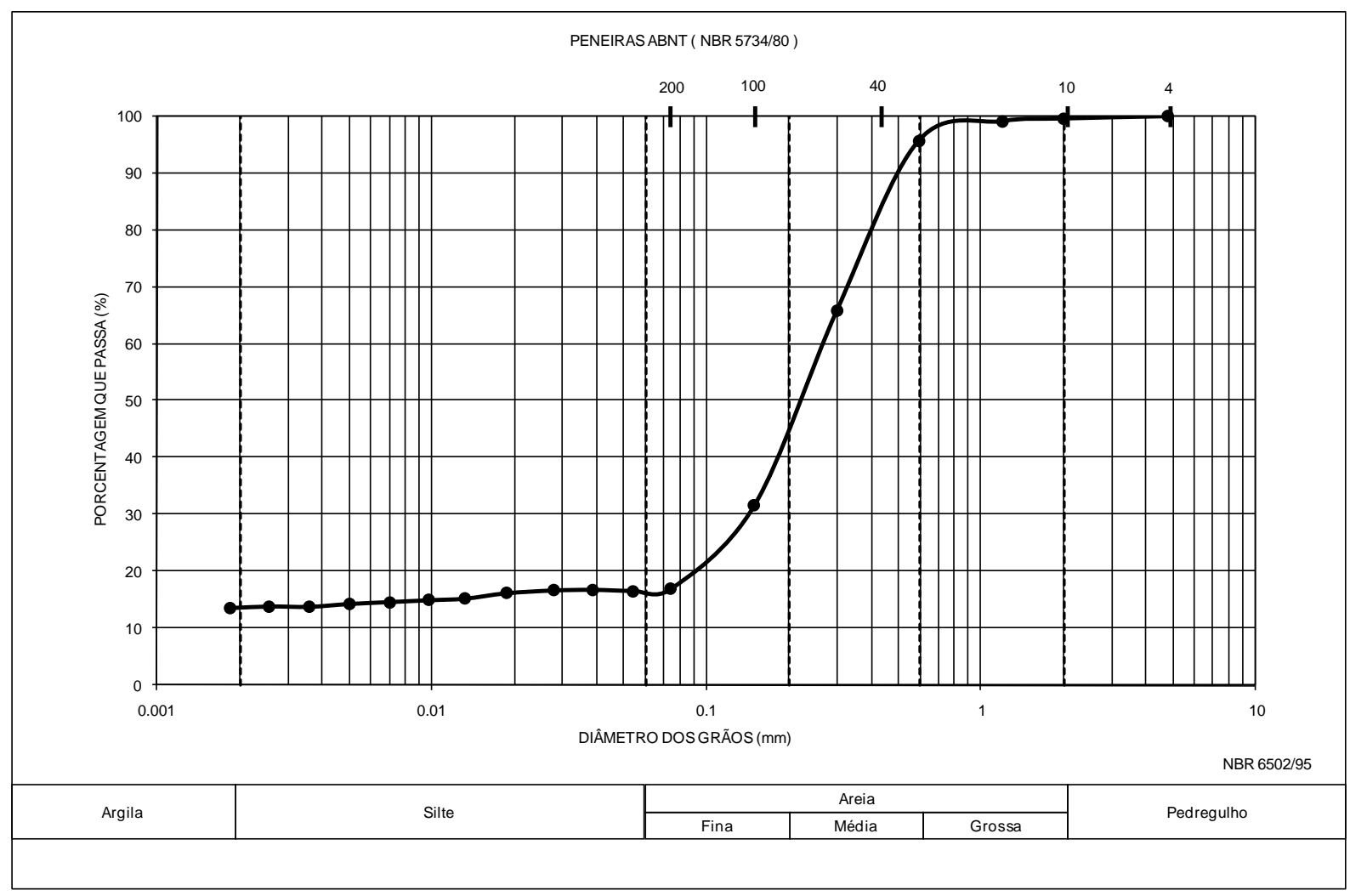

Figura 50 - Curva Granulométrica do Solo 3 (São Pedro)

O Solo 1 e o Solo 3 foram classificados como areia argilosa com distribuição granulométrica uniforme, predominando as frações de areia média e fina. Apresentam diferentes frações de finos que influenciaram nas suas características de retenção, modificando a forma e declividade das curvas de retenção de água, como será visto mais adiante.

O Solo 2 foi classificado como uma argila siltosa com $74 \%$ de finos, proveniente de um solo residual de basalto. A fração fina não foi submetida a ensaios de limites de consistência, detendo-se apenas à sua distribuição granulométrica.

\section{2. ÍNDICES FÍSICOS}

Foram calculados a partir da moldagem de cerca de 200 amostras indeformadas, úteis aos ensaios realizados, com dimensões, massa, volume e teor de umidade de moldagem conhecidos. Observam-se altos índices de vazios e porosidades relativamente altas acima de 40\%. Os valores médios iniciais são mostrados na Tabela 6. 
Tabela 6 - Índices físicos dos solos

\begin{tabular}{cccccccccc}
\hline Solo & \multirow{2}{*}{$\begin{array}{c}\text { Valores } \\
\left(\mathrm{g} / \mathrm{cm}^{3}\right)\end{array}$} & $\begin{array}{c}\rho_{\mathrm{s}} \\
\left(\mathrm{g} / \mathrm{cm}^{3}\right)\end{array}$ & $\begin{array}{c}\rho_{\mathrm{d}} \\
\left(\mathrm{g} / \mathrm{cm}^{3}\right)\end{array}$ & $\begin{array}{c}e \\
(-)\end{array}$ & $\begin{array}{c}n \\
(\%)\end{array}$ & $\begin{array}{c}\mathrm{Sr} \\
(\%)\end{array}$ & $\begin{array}{c}\mathrm{W}_{\text {mold }} \\
(\%)\end{array}$ & $\begin{array}{c}\mathrm{W}_{\text {sat }} \\
(\%)\end{array}$ \\
\hline \multirow{3}{*}{2} & $\mathrm{~m}$ & 1.517 & 2.673 & 1.320 & 1.03 & 50.63 & 39.0 & 14.9 & 38.5 \\
& $\sigma$ & 0.05 & 0.00 & 0.04 & 0.07 & 1.62 & 2.53 & 2.18 & - \\
& $\mathrm{Cv}$ & 0.03 & 0.00 & 0.03 & 0.06 & 0.03 & 0.06 & 0.15 & - \\
\hline \multirow{2}{*}{2} & $\mathrm{~m}$ & 1.314 & 2.947 & 1.045 & 1.83 & 64.55 & 41.8 & 24.3 & 58.2 \\
& $\sigma$ & 0.05 & 0.00 & 0.04 & 0.12 & 1.47 & 2.67 & 1.61 & - \\
& $\mathrm{Cv}$ & 0.04 & 0.00 & 0.04 & 0.07 & 0.02 & 0.06 & 0.07 & - \\
\hline \multirow{3}{*}{3} & $\mathrm{~m}$ & 1.615 & 2.630 & 1.529 & 0.70 & 41.25 & 20.8 & 6.0 & 29.3 \\
& $\sigma$ & 0.04 & 0.00 & 0.04 & 0.04 & 1.47 & 1.27 & 0.10 & - \\
& $\mathrm{Cv}$ & 0.02 & 0.00 & 0.02 & 0.06 & 0.04 & 0.06 & 0.02 & - \\
\hline
\end{tabular}

Sendo que:

$\rho$ - massa específica natural

$\rho_{\mathrm{d}}$ - massa específica seca

PS - massa específica dos sólidos

$e$ - índice de vazios

$n$ - porosidade

$\mathrm{Sr}$ - grau saturação inicial

$\mathrm{W}_{\text {mold }}$ - umidade de moldagem

$\mathrm{W}_{\text {sat }}$ - umidade de saturação

m - média

$\sigma$ - desvio padrão

$\mathrm{Cv}$ - coeficiente de variação

\subsection{CURVAS DE RETENÇÃO DE ÁGUA}

As curvas características para cada solo amostrado foram obtidas por secagem segundo as metodologias para os ensaios de Papel Filtro, Funil de Placa Porosa e Câmara de Richards, como já mencionado. Os três métodos foram usados conjuntamente a fim de se abranger melhor as faixas de sucção.

O Funil foi utilizado para sucções baixas e para atingir uma ampla faixa de sucção usou-se o Papel Filtro. A Câmara foi útil também para equiparar as tendências dos solos frente às várias imposições realizadas. As Figuras 51, 52 e 53 mostram as curvas para os pontos experimentais dispostos na Tabela 7 . Os teores de umidade de saturação $\left(w_{\text {sat }}\right)$ foram calculados experimentalmente. 
Tabela 7 - Pontos experimentais obtidos nos ensaios para determinação das curvas de retenção de água no solo

\begin{tabular}{|c|c|c|c|c|c|c|}
\hline & \multicolumn{2}{|c|}{ SOLO 1} & \multicolumn{2}{|c|}{ SOLO 2} & \multicolumn{2}{|c|}{ SOLO 3} \\
\hline & Wsolo (\%) & $S(\mathrm{kPa})$ & Wsolo (\%) & $S(\mathrm{kPa})$ & Wsolo (\%) & $S(\mathrm{kPa})$ \\
\hline \multirow{16}{*}{ 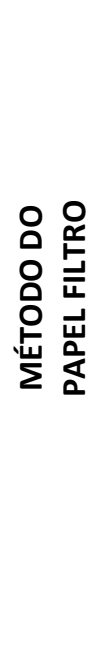 } & 27.91 & 6.2 & 48.10 & 6.3 & 21.42 & 6.4 \\
\hline & 25.57 & 6.7 & 49.01 & 6.0 & 18.91 & 5.5 \\
\hline & 24.20 & 7.2 & 42.30 & 7.2 & 17.17 & 5.4 \\
\hline & 23.57 & 6.7 & 43.82 & 6.7 & 19.47 & 5.8 \\
\hline & 28.98 & 6.1 & 39.58 & 6.7 & 15.34 & 5.5 \\
\hline & 24.90 & 6.6 & 34.87 & 7.8 & 12.99 & 6.3 \\
\hline & 21.91 & 7.6 & 31.40 & 11.6 & 10.22 & 6.1 \\
\hline & 26.29 & 6.5 & 30.94 & 17.5 & 8.35 & 8.1 \\
\hline & 19.23 & 14.2 & 28.29 & 47.2 & 5.46 & 168.7 \\
\hline & 16.31 & 72.2 & 21.53 & 5649.3 & 3.16 & 7854.0 \\
\hline & 13.71 & 1987.1 & 18.97 & 8264.2 & 3.43 & 10117.9 \\
\hline & 10.25 & 7514.8 & 14.28 & 14157.9 & 0.59 & 22880.7 \\
\hline & 8.87 & 10387.3 & 10.37 & 20501.6 & - & - \\
\hline & 2.16 & 20875.8 & 6.07 & 21896.6 & - & - \\
\hline & 1.45 & 27303.6 & 3.75 & 36118.1 & - & - \\
\hline & 1.57 & 29563.8 & - & - & - & - \\
\hline \multirow{6}{*}{ 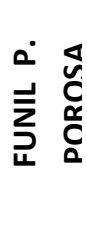 } & - & - & 54.50 & 2.0 & 22.20 & 2.0 \\
\hline & 33.59 & 3.0 & 50.90 & 3.0 & 18.23 & 3.0 \\
\hline & 23.46 & 8.0 & 37.50 & 8.0 & 10.09 & 8.0 \\
\hline & 17.37 & 13.0 & 32.98 & 12.0 & 7.30 & 13.0 \\
\hline & 20.37 & 10.0 & 26.79 & 10.0 & 7.65 & 10.0 \\
\hline & 17.40 & 20.0 & 24.60 & 20.0 & 5.57 & 20.0 \\
\hline \multirow{7}{*}{ 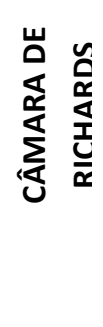 } & - & - & - & - & 5.39 & 50.0 \\
\hline & 14.43 & 100.0 & 25.00 & 100.0 & 4.84 & 100.0 \\
\hline & 12.05 & 200.0 & 22.23 & 200.0 & 4.75 & 200.0 \\
\hline & 12.16 & 500.0 & 19.44 & 500.0 & 5.16 & 500.0 \\
\hline & 11.58 & 800.0 & 18.73 & 800.0 & 4.78 & 800.0 \\
\hline & Wsolo (\%) & $S(\mathrm{kPa})$ & W solo (\%) & $S(\mathrm{kPa})$ & Wsolo (\%) & $S$ (kPa) \\
\hline & 33.92 & 0.1 & 57.37 & 0.1 & 23.76 & 0.1 \\
\hline
\end{tabular}

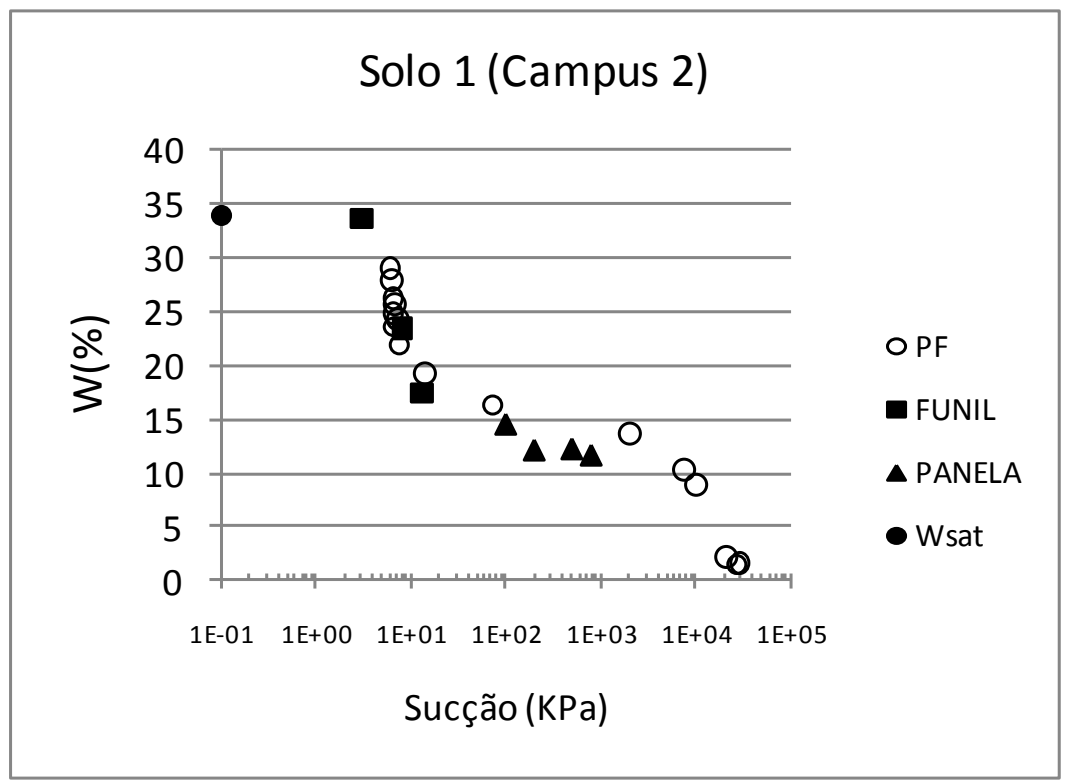

Figura 51 - Curva de retenção de água - Solo 1 


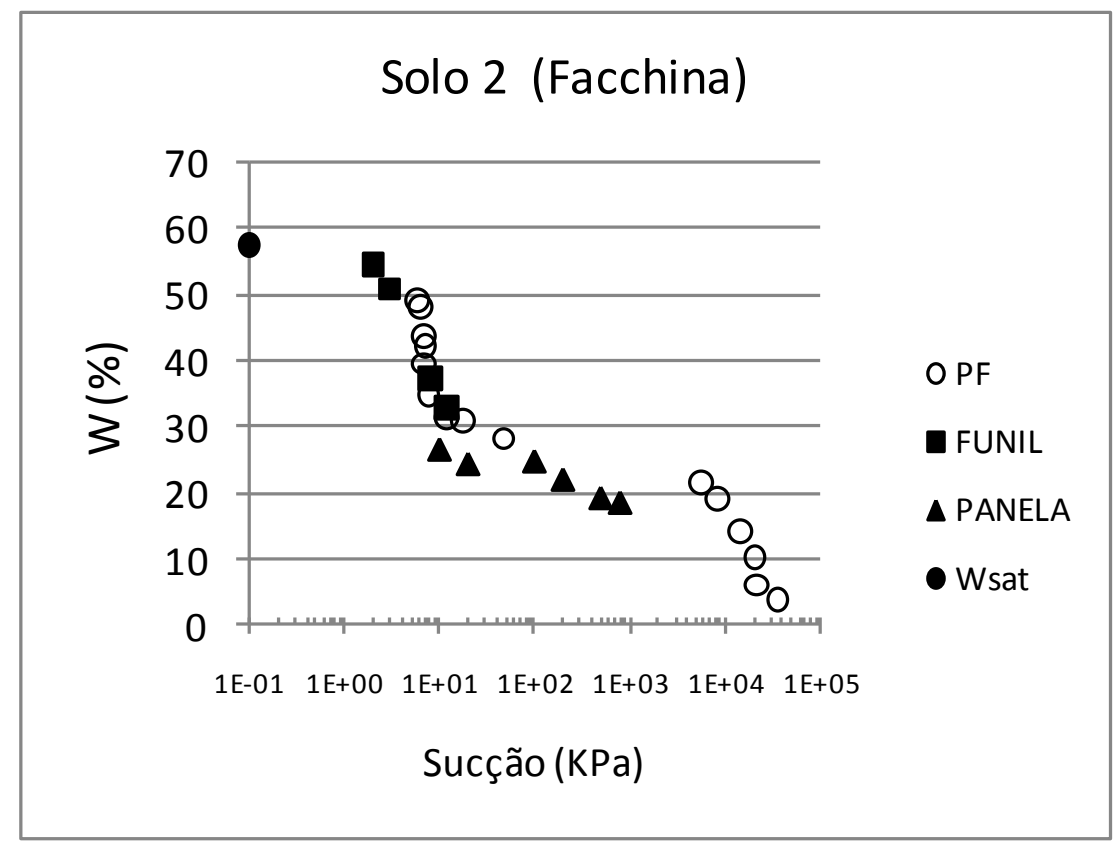

Figura 52 - Curva de retenção de água - Solo 2

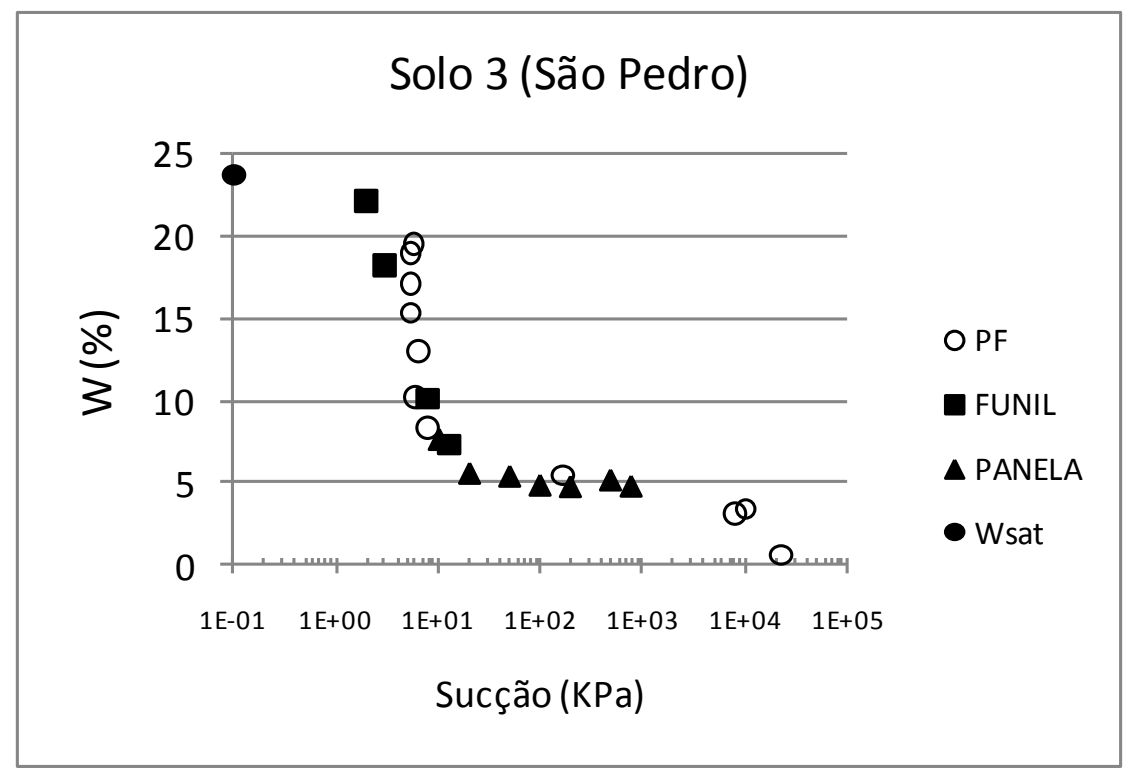

Figura 53 - Curva de retenção de água - Solo 3

Nas faixas de sucção onde houve sobreposição de valores, observa-se que há uma concordância de resultados entre os três métodos utilizados. Nas demais faixas os resultados se complementam, permitindo a obtenção de uma curva de retenção de água mais bem definida. Usando as relações empíricas de Van Genutchen (1980), estipulou-se a curva característica de acordo com parâmetros de ajuste modelados como: 


$$
\begin{gathered}
w=w_{r}+\frac{\left(w_{S}-w_{r}\right)}{\left(1+|\alpha \cdot S|^{n}\right)^{m}} \\
m=1-\frac{1}{n}
\end{gathered}
$$

Sendo que $w, w_{r} e w_{s}$ são, respectivamente, as umidades gravimétrica, residual e de saturação; $\alpha, n$ e $m$ são parâmetros de forma da curva de retenção, e $S$ é a sucção matricial. As curvas foram ajustadas no Software SWRC, utilizando os dados do Papel Filtro e do Funil. São apresentadas na forma de umidade gravimétrica versus a sucção em $k P a$ nas Figuras 54, 55 e 56. Os parâmetros de ajuste das curvas são apresentados na Tabela 8.

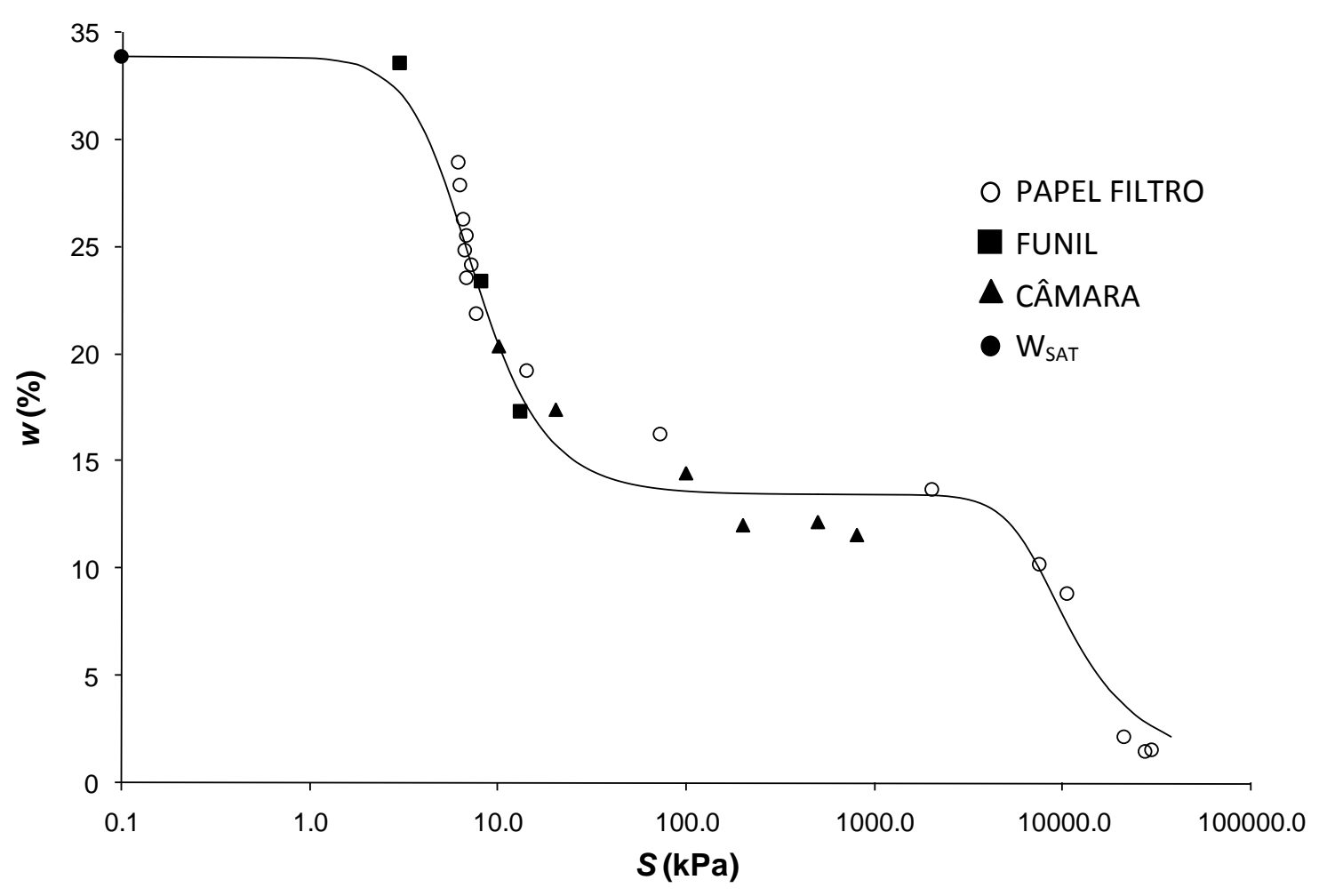

Figura 54 - Curva de retenção de água ajustada - Solo 1 


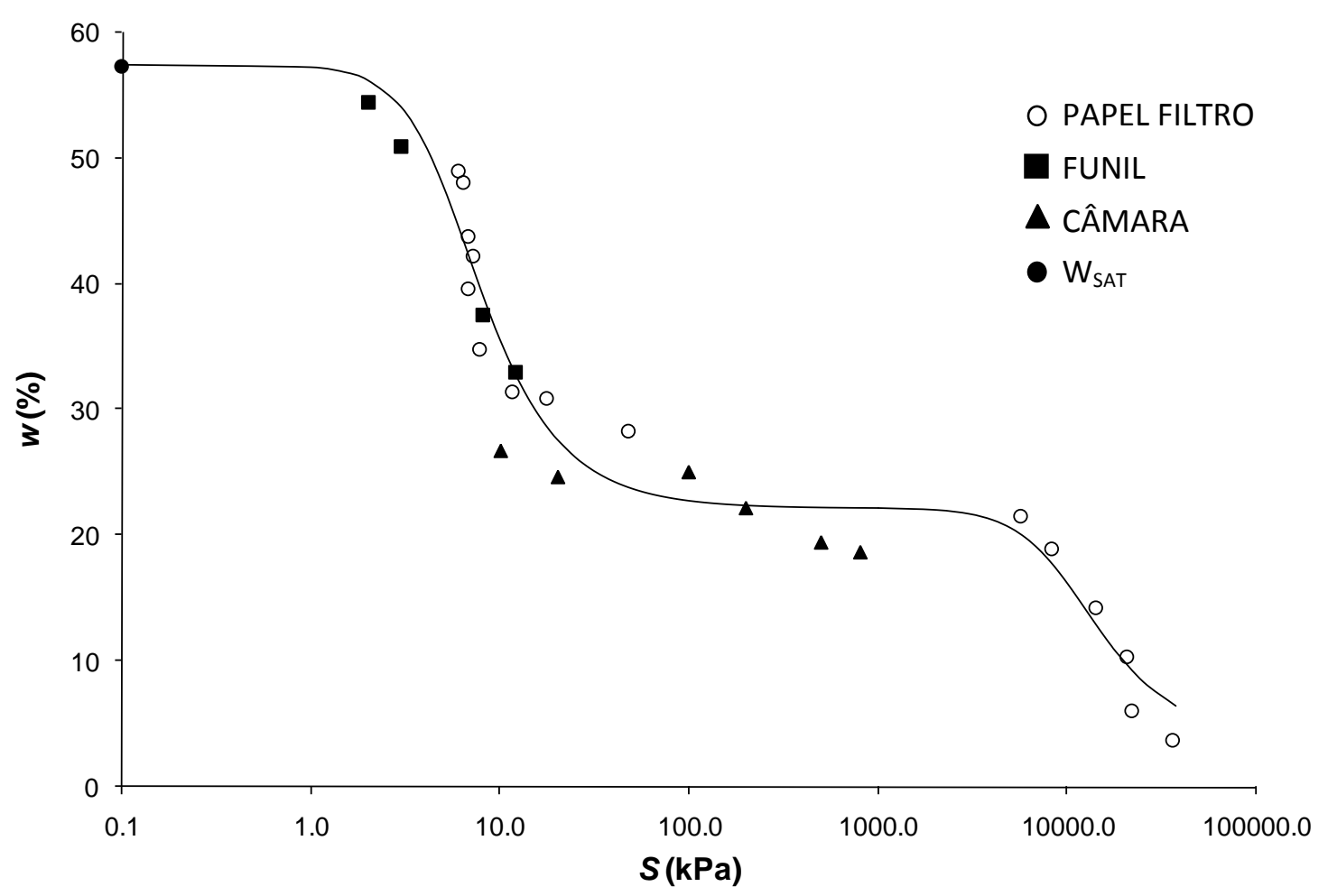

Figura 55 - Curva de retenção ajustada - Solo 2

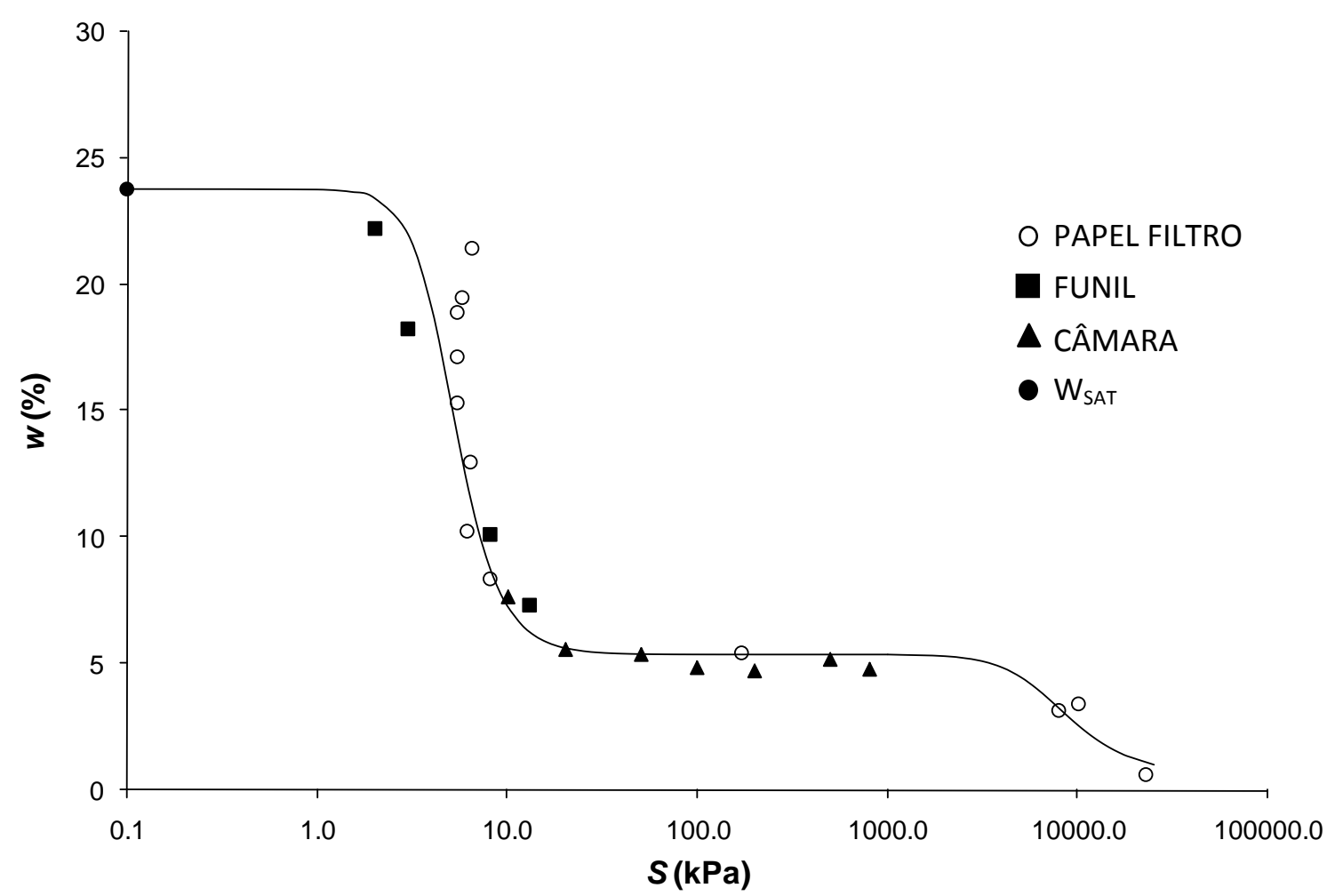

Figura 56 - Curva de retenção ajustada - Solo 3 
Tabela 8 - Parâmetros de ajuste das curvas de retenção de água por Van Genutchen (1980)

\begin{tabular}{cccccccc}
\hline SOLO & AJUSTE & $\alpha$ & $m$ & $n$ & $\mathrm{wr}$ & $\mathrm{Ws}$ & $\mathrm{r}^{2}$ \\
\hline \multirow{2}{*}{1} & $\mathrm{a}$ & 0.1750 & 0.591 & 2.892 & 13.50 & 33.90 & 0.974 \\
& $\mathrm{~b}$ & 0.0002 & 0.351 & 3.757 & 0.86 & 13.50 & 0.916 \\
\hline \multirow{2}{*}{2} & $\mathrm{a}$ & 0.1890 & 0.512 & 2.708 & 22.20 & 57.40 & 0.938 \\
& $\mathrm{~b}$ & 0.0001 & 0.581 & 2.529 & 3.75 & 22.20 & 0.907 \\
\hline \multirow{2}{*}{3} & $\mathrm{a}$ & 0.2150 & 0.692 & 4.215 & 5.36 & 23.76 & 0.956 \\
& $\mathrm{~b}$ & 0.0002 & 0.593 & 3.002 & 0.59 & 5.36 & 0.925 \\
\hline
\end{tabular}

Baseado no comportamento bimodal das curvas de retenção de água, adotou-se o mesmo critério usado por Rodrigues (2007) onde o ajuste foi dividido em duas partes (Tabela 8). O ajuste inicial (a) representa o trecho da curva onde ocorre a dessaturação dos macroporos devido à primeira pressão de entrada de ar. O segundo ajuste (b) ocorre devido à pressão de entrada de ar necessária à expulsão da água dos microporos. A umidade de saturação do ajuste (b) foi adotada como a umidade residual do ajuste (a).

Este comportamento bimodal das curvas também foi verificado por Soto (2004) ao ensaiar um caulim comercial e um solo arenoso proveniente da região de São Carlos; e por Rodrigues (2007) em análises com solos arenosos porosos da região noroeste do Estado, em Pereira Barreto (SP).

Uma análise das curvas de retenção de cada solo permitiu inferir que as relações sucçãoumidade estão diretamente relacionadas à distribuição granulométrica dos solos, o índice de vazios, a percentagem de finos e a mineralogia.

Observou-se que, o solo argiloso (Solo 2), menos permeável, com partículas mais coesas e quantidade maior de microporos admitiu sucções maiores para os mesmos teores de umidade dos solos arenosos. Já o solos arenosos (Solo 1 e Solo 3) apresentaram um formato diferente das curvas devido à rápida drenagem que sofrem pelo esvaziamento progressivo dos macroporos.

Os macroporos influenciam o trecho inicial da curva, pois é quando se registra a passagem de ar com um valor de pressão necessária para esvaziar o maior poro da estrutura (Röhm, 2004). As altas porosidades dos três solos $(n>40 \%)$ possibilitaram baixas pressões de entrada de ar $(<5 \mathrm{kPa})$, o que demonstra relativa facilidade de drenagem dos macroporos dos solos mesmo para baixas sucções.

Com base nestas curvas de retenção foram definidas as sucções que seriam impostas aos solos a fim de prepará-los para o ensaio de absorção d'água, segundo às umidades de 
equilíbrio correspondentes. Para tanto, novas amostras foram submetidas à Câmara de Pressão de Richards e ao Funil de Placa Porosa. Escolheram-se sucções de 2, 3, 4, 5, 8, 10, 13, 20, 50, 100, 200, 500 e 800 kPa, em função do tipo de solo e das limitações de cada equipamento.

\subsection{CURVAS DE ABSORÇÃo DE ÁGUA}

As curvas de absorção $\left(q x t^{0.5}\right)$ foram formadas segundo os dados de pelo menos 2 amostras indeformadas, como exemplificado na Figura 57. Foram plotadas curvas de absorção a partir de valores médios de $q$ e usados os parâmetros destas curvas, como mostrado nos Anexos 1, 2 e 3. Obtiveram-se curvas de absorção segundo o grau de saturação para cada solo em função de cada sucção imposta. Optou-se por analisar as diferentes possibilidades de relações $q x t^{0.5}$, considerando ou não o ajuste partindo da origem, ponto $(0,0)$, de zero tempo para zero absorção. A Tabela 9 apresenta, para cada solo, os valores de $q$ em função do tempo $(t)$.

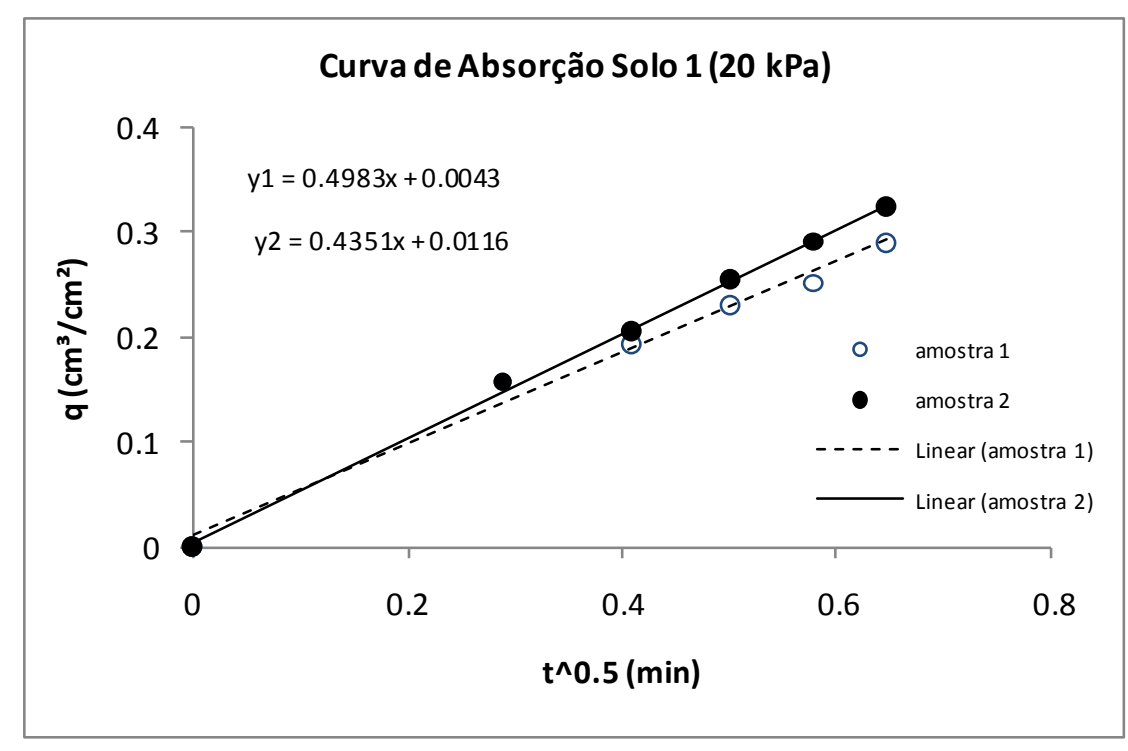

Figura 57 - Curva de absorção de água

O índice de absorção d'água $\left(I_{a b s}\right)$ equivale ao coeficiente angular da reta ajustada aos pontos experimentais. Foram utilizados apenas os pontos equivalentes ao trecho da reta com maior inclinação, desconsiderando-se os pontos após a inflexão da reta, visto que os primeiros são representantes do potencial de absorção. 
Analisaram-se 03 (três) possibilidades de ajuste desta reta: nas primeiras considerou-se o ponto zero, forçando ou não a passagem da reta de regressão por este ponto, denominadas de Curva1 e Curva 2, respectivamente; na terceira (Curva 3), ajustou-se a reta considerando somente os pontos experimentais. Dos três casos, as relações com maiores coeficientes de determinação $\left(\mathrm{R}^{2}\right)$ foram consideradas, apesar de não se notarem significativas diferenças em seus valores.

Tabela 9 - Valores de $q$ em função do $t$

\begin{tabular}{|c|c|c|c|c|c|c|c|c|c|c|c|c|c|c|c|c|c|c|c|c|c|c|c|c|c|c|c|c|}
\hline \multirow{3}{*}{$\begin{array}{l}\mathrm{t}^{0.5} \\
(\min )\end{array}$} & \multicolumn{28}{|c|}{ Valores de $q\left(\mathrm{~cm}^{3} / \mathrm{cm}^{2}\right)$ para cada $S(\mathrm{kPa})$} \\
\hline & \multicolumn{9}{|c|}{ Solo 1} & \multicolumn{9}{|c|}{ Solo 2} & \multicolumn{10}{|c|}{ Solo 3} \\
\hline & 2 & 5 & 10 & 20 & 100 & 200 & 500 & 800 & secas & 2 & 5 & 10 & 20 & 100 & 200 & 500 & 800 & secas & 2 & 4 & 10 & 20 & 50 & 100 & 200 & 500 & 800 & secas \\
\hline 0.29 & 0.11 & 0.12 & 0.17 & 0.16 & 0.27 & 0.29 & 0.36 & 0.27 & 0.60 & 0.12 & 0.18 & 0.17 & 0.17 & 0.12 & 0.48 & 0.33 & 0.22 & 0.84 & 0.09 & 0.19 & 0.27 & 0.28 & 0.30 & 0.03 & 0.41 & 0.46 & 0.15 & 0.58 \\
\hline 0.41 & 0.13 & 0.15 & 0.22 & 0.20 & 0.39 & 0.44 & 0.47 & 0.41 & 0.94 & 0.13 & 0.25 & 0.28 & 0.28 & 0.24 & 0.68 & 0.48 & 0.42 & 1.23 & 0.10 & 0.24 & 0.42 & 0.44 & 0.43 & 0.11 & 0.58 & 0.57 & 0.29 & 0.84 \\
\hline 0.50 & 0.13 & 0.15 & 0.26 & 0.24 & 0.47 & 0.53 & 0.54 & 0.50 & 1.06 & 0.13 & 0.28 & 0.36 & 0.37 & 0.34 & 0.75 & 0.58 & 0.60 & 1.35 & 0.10 & 0.24 & 0.50 & 0.56 & 0.55 & 0.16 & 0.64 & 0.71 & 0.48 & \\
\hline 0.58 & 0.13 & & 0.30 & 0.27 & 0.52 & 0.60 & 0.58 & 0.57 & & 0.13 & & 0.47 & 0.45 & 0.42 & 0.77 & 0.64 & 0.71 & & 0.11 & & 0.52 & 0.57 & 0.59 & 0.21 & 0.66 & 0.75 & 0.60 & \\
\hline 0.65 & 0.10 & & 0.31 & 0.31 & 0.54 & 0.63 & 0.60 & 0.60 & & 0.13 & & 0.48 & 0.51 & 0.50 & & 0.77 & 0.79 & & 0.11 & & 0.58 & 0.62 & 0.60 & 0.29 & & 0.80 & 0.67 & \\
\hline 0.71 & 0.10 & & & 0.33 & & & & 0.63 & & 0.13 & & & 0.56 & 0.54 & & & 0.80 & & 0.11 & & & & 0.65 & 0.36 & & & 0.73 & \\
\hline 0.76 & 0.17 & & & & & & & & & 0.13 & & & 0.58 & 0.56 & & & 0.83 & & 0.11 & & & & & 0.40 & & & 0.76 & \\
\hline 0.87 & & & & & & & & & & 0.14 & & & & 0.53 & & & & & 0.10 & & & & & 0.45 & & & 0.77 & \\
\hline 1.00 & & & & & & & & & & 0.14 & & & & 0.58 & & & & & 0.11 & & & & & 0.48 & & & & \\
\hline 1.12 & & & & & & & & & & 0.16 & & & & 0.63 & & & & & & & & & & & & & & \\
\hline 1.29 & & & & & & & & & & 0.16 & & & & 0.68 & & & & & & & & & & & & & & \\
\hline
\end{tabular}

\subsection{CORRELAÇÃO - (Iabs $x S)$}

Segundo as faixas de sucção imposta e os teores de umidade gravimétrica correspondentes, os valores dos índices de absorção se apresentam na Tabela 10. Considerando o intervalo das sucções impostas, o Solo 1 apresentou coeficientes $\mathrm{R}^{2}$ de 0,994 a 1,000; o Solo 2 obteve $\mathrm{R}^{2}$ de 0,992 a 1,000; o Solo 3 obteve entre 0,942 e 1,000.

Tabela 10 - Valores de Índices de absorção dos solos

\begin{tabular}{|ccc|ccc|ccc|}
\hline \multicolumn{3}{|c|}{ SOLO 1 } & \multicolumn{3}{c|}{ SOLO 2 } & \multicolumn{3}{c|}{ SOLO 3 } \\
\hline S (kPa) & Wsolo (\%) & Iabs & S (kPa) & Wsolo (\%) & Iabs & S (kPa) & Wsolo (\%) & labs \\
\hline 2 & 20,29 & 0,10 & 2 & 51,01 & 0,07 & 2 & 22,2 & 0,06 \\
5 & 23,42 & 0,20 & 5 & 42,91 & 0,58 & 5 & 13,03 & 0,35 \\
10 & 20,37 & 0,44 & 10 & 26,79 & 1,01 & 10 & 7,68 & 1,15 \\
20 & 17,40 & 0,42 & 20 & 24,6 & 1,22 & 20 & 5,57 & 1,32 \\
- & - & - & - & - & - & 50 & 5,39 & 1,05 \\
100 & 14,43 & 0,93 & 100 & 25 & 0,97 & 100 & 4,84 & 0,82 \\
200 & 12,05 & 1,01 & 200 & 22,23 & 1,4 & 200 & 4,75 & 1,19 \\
500 & 12,16 & 0,69 & 500 & 19,44 & 1,17 & 500 & 5,16 & 1,25 \\
800 & 11,58 & 1,00 & 800 & 18,73 & 1,62 & 800 & 4,78 & 1,36 \\
secas ao ar & 1,35 & 2,18 & secas ao ar & 3,87 & 2,8 & secas ao ar & 0,5 & 2,11 \\
\hline \multicolumn{8}{|c}{}
\end{tabular}


Observa-se uma nítida tendência de aumento da absorção de água com o aumento da sucção e conseqüente diminuição do teor de umidade, o que vem ao encontro do conceito de sucção que é a avidez do solo pela água. No entanto, alguns pontos discrepantes ocorreram, como para a sucção de $100 \mathrm{kPa}$, tanto no Solo 2 quanto no Solo 3. Estes valores podem ter sido causados por erros no ensaio de sucção, quanto no de absorção de água, pois são casos isolados.

O Solo 3 demonstrou valores mais elevados para os índices $I_{a b s}$, consequência de sua condutividade hidráulica elevada. Mota (2008) mostrou através de ensaio apropriado que a condutividade hidráulica deste solo é elevada e da ordem de grandeza de $10^{-3} \mathrm{~cm} / \mathrm{seg}$.

No entanto, seus índices mais expressivos, em relação aos demais solos, não significam que sua capacidade de retenção seja diretamente proporcional. Estes valores apenas demonstram que o material é ávido por água para uma faixa de umidades baixas, sendo que a água é facilmente expulsa na mesma proporção em que infiltra. Sendo observada a concordância entre diminuição do teor de umidade e aumento da absorção de água, buscou-se estabelecer a relação entre o $I_{a b s}$ e a Sucção $(S)$ (Figura 58).

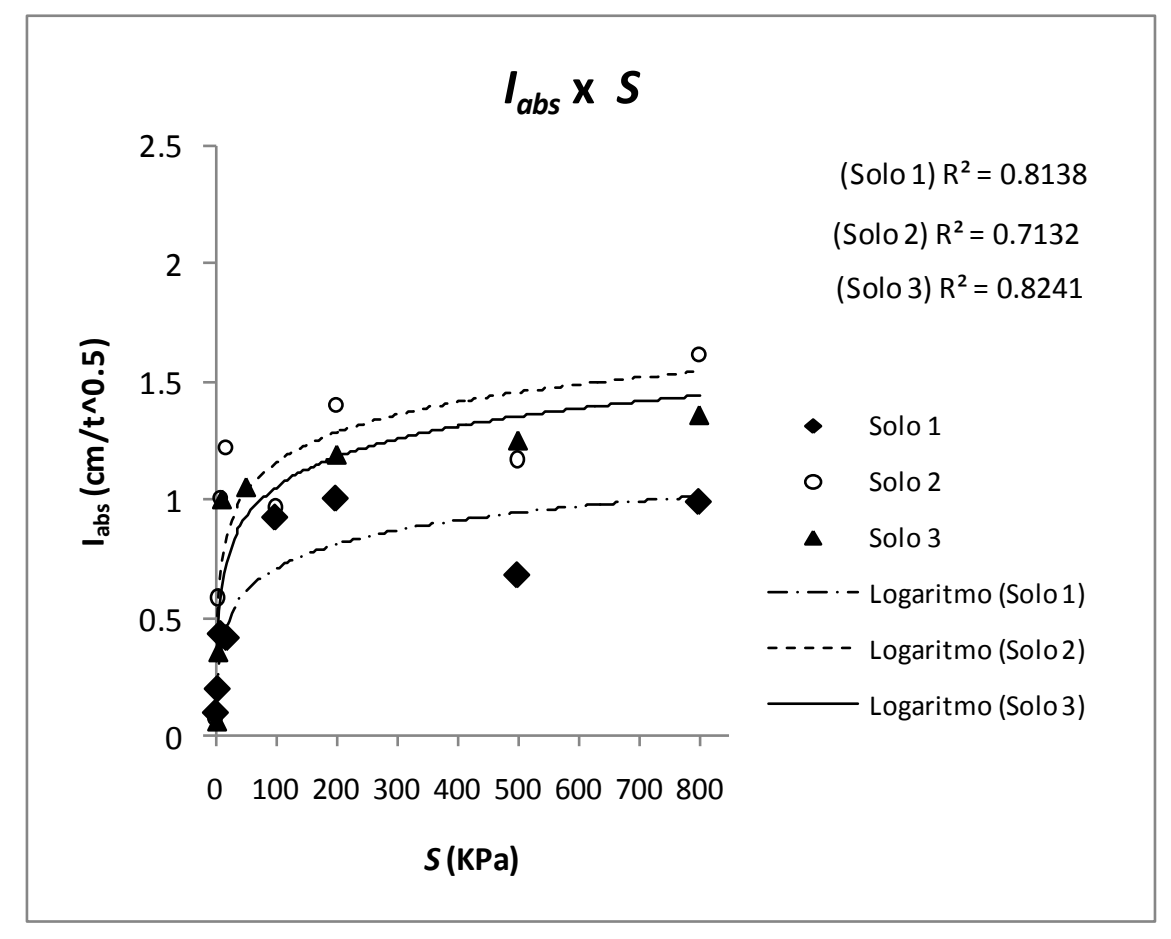

Figura 58 - Relação entre o $I_{a b s}$ e a Sucção

O Solo 1 e o Solo 3, mais arenosos, mostraram melhor relação entre aumento da sucção com o aumento do $I_{a b s}\left(\mathrm{R}^{2}\right.$ entre 0,81 e 0,82$)$, enquanto que o Solo 2 exibiu correlação inferior 
$\left(\mathrm{R}^{2}=0,71\right)$. Este fato pode estar relacionado ao maior teor de argila deste solo, que mesmo com sucções mais altas, não apresenta absorção de água tão rápida, devido ao tamanho reduzido dos poros. Buscando-se amenizar esta influência, dividiu-se o valor do $I_{a b s}$ pela respectiva umidade inicial do solo ensaiado e, correlacionou-se com o valor da sucção (Figura $59)$.

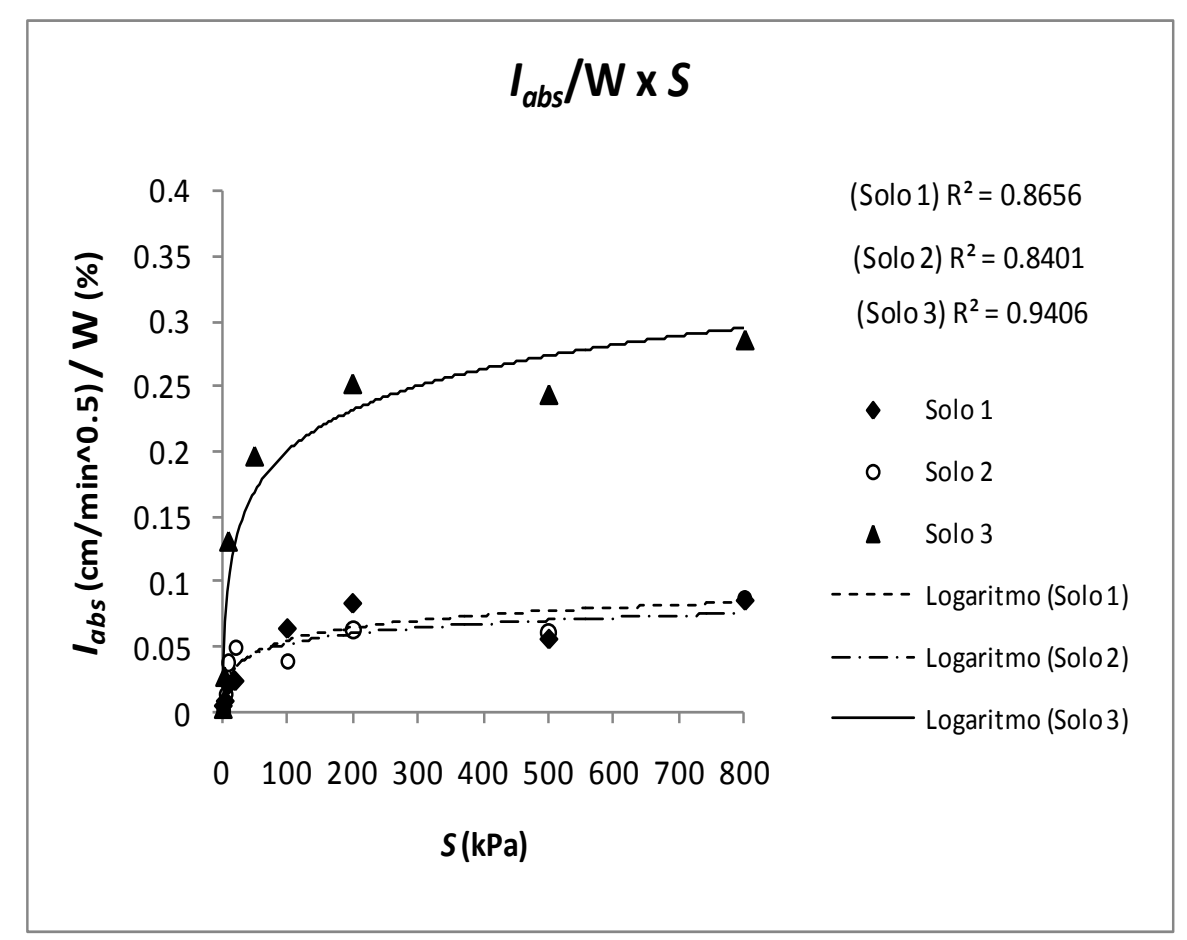

Figura 59 - Relação entre a razão do $I_{\text {abs }}$ pelo teor de umidade e a Sucção

Comparando as Figuras 58 e 59, verificou-se uma melhora na correlação para os três solos. Portanto, considerou-se que esta forma de análise conduz a uma melhor compreensão da influência da sucção na absorção de água.

\subsection{CORRELAÇÃO - $(S x E)$}

As amostras representativas provenientes da região de São Pedro confirmaram o comportamento erodível do solo quando analisadas segundo as formulações (10) e (11). Ao contrário dos solos com fração fina que encontraram na coesão estrutural estabilidade favorável contra a desagregação de suas partículas.

Valores de $E_{52}$ e $E_{40}$ podem ser vistos na Tabela 11 e Figura 60, caracterizando o Solo 3 como erodível $(E<1)$, e os Solos 1 e 2 como não erodíveis $(E>1)$. Constam também na tabela os valores médios de $P$ para cada sucção. 
No geral, notou-se que o aumento da sucção (redução do teor de umidade) parece conduzir maiores perdas $(P)$ no ensaio de perda de massa por imersão. Como solos com altas perdas são, em geral, muito susceptíveis à erosão, isto vem demonstrar a importância que tem a perda de umidade natural do solo no processo erosivo. Assim sendo, quanto mais seco estiver um solo, quando do início do evento chuvoso, maior poderá ser sua desagregação e consequentemente sua erodibilidade.

Tabela 11 - Valores de $E$ para os Solos

\begin{tabular}{|c|cccc|cccc|cccc|}
\cline { 2 - 13 } \multicolumn{1}{c|}{} & \multicolumn{4}{c|}{ SOLO 1 } & \multicolumn{4}{c|}{ SOLO 2 } & \multicolumn{3}{c|}{ SOLO 3 } \\
\hline$S(\mathrm{kPa})$ & labs & $\mathrm{P}(\%)$ & E40 & E52 & labs & $\mathrm{P}(\%)$ & E40 & E52 & labs & $\mathrm{P}(\%)$ & E40 & E52 \\
\hline 2 & 0,10 & 0,92 & 4,35 & 5,65 & 0,07 & 0,43 & 6,51 & 8,47 & 0,06 & 66,29 & 0,04 & 0,05 \\
5 & 0,20 & 4,39 & 1,82 & 2,37 & 0,58 & 0,83 & 27,95 & 36,34 & 0,35 & 69,15 & 0,20 & 0,26 \\
10 & 0,44 & 20,55 & 0,86 & 1,11 & 1,01 & 25,4 & 1,59 & 2,07 & 1,15 & 74,39 & 0,62 & 0,80 \\
20 & 0,42 & 7,66 & 2,19 & 2,85 & 1,22 & 76,27 & 0,64 & 0,83 & 1,32 & 64,47 & 0,82 & 1,06 \\
50 & - & - & - & - & - & - & & & 1,05 & 68,01 & 0,62 & 0,80 \\
100 & 0,93 & 39,18 & 0,95 & 1,23 & 0,97 & 51,98 & 0,75 & 0,97 & 0,82 & 74,58 & 0,44 & 0,57 \\
200 & 1,01 & 42,81 & 0,94 & 1,23 & 1,40 & 14,39 & 3,89 & 5,06 & 1,19 & 76,12 & 0,63 & 0,81 \\
800 & 1,00 & 22,12 & 1,81 & 2,35 & 1,62 & 56,25 & 1,15 & 1,50 & 1,36 & 75,58 & 0,72 & 0,94 \\
secas ao ar & 2,18 & 39,81 & 2,19 & 2,85 & 2,80 & 21,73 & 5,15 & 6,70 & 2,11 & 70,56 & 1,20 & 1,55 \\
\hline
\end{tabular}

Na Figura 60, observa-se que o critério proposto por Pejon (1992) se aproxima da realidade de campo dos solos. Das amostras ensaiadas do Solo 3, verifica-se que apenas 01 (uma) apresenta $E>1$ contrariando o comportamento erodível do material visto em campo. Pejon (1992) também verificou tal comportamento em amostras de solo comprovadamente erodíveis e, sem considerar a influência da sucção, atribuiu isso à presença de matéria orgânica que, ao mesmo tempo que permite um aumento na absorção de água provoca menores perdas de massa devido aos grumos estáveis formados.

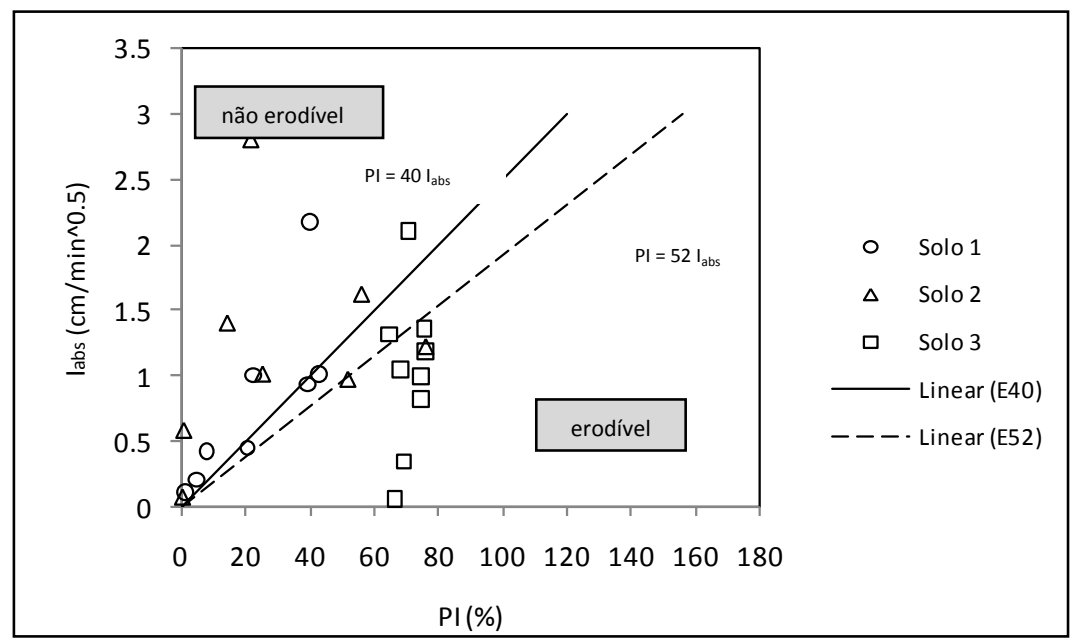

Figura 60 - Resultados para o Ensaio de Erodibilidade 


\section{CONCLUSÃO}

Os resultados obtidos neste trabalho permitiram verificar a relação entre o aumento da sucção e o aumento da velocidade de absorção de água em três solos com origem e granulometria diferentes. Observaram-se melhores correlações para os solo mais arenoso (Solo 3), devido provavelmente ao predomínio das sucções matriciais nestes solos. Já o solo mais argiloso (Solo 2) apresentou correlações inferiores, mas ainda assim significativas.

O estudo mostrou ainda a relevante influência que o fenômeno da secagem, com conseqüente aumento da sucção, pode ter no despreendimento das partículas do solo provocando perda de massa por imersão. Este efeito ficou mais evidente nos Solos 1 e 2, com maior percentagem de finos, quando se comportaram de duas formas: a) para sucções menores que $5 \mathrm{kPa}$ apresentaram perdas insignificantes de material; b) para valores de sucção elevados, atingiram mais de $40 \%$ de perdas. Já para o Solo 3, essencialmente arenoso, as perdas foram altas mesmo para as sucções baixas.

Como a perda de massa por imersão é um importante indicativo de desagregabilidade do solo, fator de relevância na medida de sua erodibilidade, infere-se que o efeito da secagem dos solos pode contribuir para o aumento da suscetibilidade à erosão de solos inicialmente pouco erodíveis. Portanto, a recomendação de secagem prévia da amostra, para a realização do Ensaio de Erodibilidade, proposto por Nogami e Villibor (1979) se justifica plenamente.

Constatou-se também, nesta pequisa, a boa relação do índice de absorção ( $\left.\mathrm{I}_{\mathrm{abs}}\right)$ com a sucção $(S)$, apresentando coeficientes de determinação $\left(R^{2}\right)$ em torno de 0,9. Desta maneira, a realização do ensaio de absorção d'água, para um determinado solo, poderia permitir estimar, com boa aproximação, a faixa de sucção em que se encontra. Como este ensaio é facilmente exequíivel, sendo realizado em no máximo 2 minutos, permitiria rápida estimativa da sucção sem os dispêndios dos equipamentos onerosos.

Por fim, o estudo mostrou novamente a boa concordância da erodibilidade do solo, determinada pelo método proposto por Nogami e Villibor (1979). Porém, apenas a região da amostra 3 (São Pedro) se classificou como erodível, apresentando problemas de erosão acelerada observados em campo. 


\section{REFERÊNCIAS BIBLIOGRÁFICAS}

Abramento, M. (1988). Resistência ao cisalhamento de solos não saturados: considerações teóricas e estudo experimental sobre solo coluvionar das encostas da Serra do Mar. Dissertação de Mestrado - Escola Politécnica, Universidade de São Paulo, São Paulo.

Alcântara, M. A. T. (1997). Estudo da Erodibilidade de alguns solos do Estado de São Paulo. Dissertação de Mestrado - Escola de Engenharia de São Carlos, Universidade de São Paulo, São Carlos, 129p.

Almeida, F.F.M, (1964). Fundamentos Geológicos do Relevo Paulista. Inst.Geogr.Geol. Bol. v 41, 167-263, São Paulo.

Amon, R. S. (1994). Variação da erodibilidade do solo durante o ano. Dissertação de Mestrado - Escola Superior de Agricultura "Luiz de Queiroz", Universidade de São Paulo, São Paulo, 46p.

Ângulo, R. J. (1984). Relações entre a erodibilidade e agregação, granulometria e características químicas de solos brasileiros. R. bras. Ci. Solo, v. 8: 133-138.

ASSOCIAÇÃO BRASILEIRA DE NORMAS TÉCNICAS. (1984). Solo - Análise granulométrica - Método de ensaio - Procedimento: NBR7181: 1984. Rio de Janeiro.

ASSOCIAÇÃO BRASILEIRA DE NORMAS TÉCNICAS. (1984). Solo - Grãos de solos que passam na peneira de $4,8 \mathrm{~mm}$ - Determinação da massa específica - Método de ensaio - Procedimento: NBR6508: 1984. Rio de Janeiro.

ASSOCIAÇÃO BRASILEIRA DE NORMAS TÉCNICAS. (1995). Rochas e Solos Terminologia: NBR6502: 1995. Rio de Janeiro.

Bastos, C. A. B. (1997). Estudo da resistência ao cisalhamento de um solo erodível em trajetórias de umedecimento e secagem. Anais do $3^{\circ}$ Simpósio Brasileiro de Solos Não Saturados. Vol.1, Rio de Janeiro - RJ. 179 - 187.

Bastos, C. A. B. (2004). Estudo geotécnico sobre a erodibilidade de solos residuais não saturados. Tese de Doutorado - Escola de Engenharia da Universidade Federal do Rio Grande do Sul, RS. 303p. 
Bazzano, M. G. P. (2007). Erosividade, coeficiente de chuva, padrões e período de retorno das chuvas de Quaraí, RS. R. Bras. Ci. Solo, v. 31: 1205-1217.

Bueno, B. S. \& Vilar, O. M. (1979). Mecânica dos solos. Vol 1. Departamento de Geotecnia, EESC, USP. São Carlos, SP. 132p.

Beneveli, R. M. (2004). Efeitos da secagem seguida da saturação na resistência de um solo compactado em laboratório. Anais do $5^{\circ}$ Simpósio Brasileiro de Solos Não Saturados, Vol. 1. EESC, USP. São Carlos - SP. 9 - 13.

Bigarella, J. J.; mazuchowski, J. Z. (1985). Visão integrada da problemática da erosão. ABGE-ADEA, Maringá, 332p.

Borma, L. S. (2004). Aspectos teóricos da modelagem do balanço hídrico no sistema soloplanta-atmosfera. Anais do $5^{\circ}$ Simpósio Brasileiro de Solos Não Saturados, Vol. 1. EESC, USP. São Carlos - SP. $217-222$.

Bryan, R. B. (1969). The development, use and efficiency of índices of soil erodibility. Geoderma, v. 2, Elsevier Publishing Company, Amsterdam. 5 - 26.

Bullut, R. (2005). Free Energy of Water-8uction-in Filter Papers. Geotechnical Testing Journal, VoI. 28, No. 4, $355-363$.

Burgos, P. C. (2005). Sorção e condutividade hidráulica de alguns solos da cidade de Salvador - BA, a partir do ensaio de infiltrabilidade do método MCT. Anais da IV Conferência Brasileira Sobre Estabilidade de Encostas, COBRAE, Vol. 1, Salvador - BA, $253-261$.

Camapum de Carvalho; Sales, M. M.; Souza, N. M.; Melo, M. T. S. (2006). Processos erosivos no Centro-Oeste brasileiro. UNB, FINATEC, Brasília, 464p.

Campos, L. E. P. (2002). Utilização de parâmetros de solos não saturados em encostas. Anais do XVI Congresso Argentino de Mecânica de Suelos e Ingenieria Geotecnica (XVI CAMSIG), Patagônia, Argentina.

Cardoso júnior, C. R. (2006). Estudo do comportamento de um solo residual de gnaisse não saturado para avaliar a influência da infiltração na estabilidade de taludes. Dissertação de Mestrado - Escola Politécnica, Universidade de São Paulo, São Paulo, 172p. 
Carvalho, J. C. (2005). Mecanismos de instabilização de taludes de erosões. Anais da IV Conferência Brasileira Sobre Estabilidade de Encostas, COBRAE, Vol. 1, Salvador - BA, $361-372$.

Carvalho, M. P. (1997). Parâmetros de erosividade da chuva e da enxurrada correlacionados com as perdas de solo e determinação da erodibilidade de um podzólico vermelho-amarelo de Pindorama. R. bras. Ci. Solo, Campinas, 21; 279-286.

Cavalhero, A. (2005). Relação entre permeabilidade e absorção de água no estudo de processos erosivos. $13^{\circ}$ Simpósio Internacional de Iniciação Científica, SIICUSP, São Carlos, SP.

Cavalieri, A. (1994). Erodibilidade do solo: avaliação por meio de propriedades físicas e químicas. Dissertação de Mestrado - Faculdade de Engenharia Agrícola, Universidade Estadual de Campinas, Campinas - SP. 80p.

Centurion, J. F. (1997). Comparação de métodos para determinação da curva de retenção de água em solos. R. bras. Ci. Solo, Campinas, 21:173-179.

CEPAGRI - UNICAMP. Disponível em http://www.cpa.unicamp.br/outrasinformacoes/clima_muni_007.html. Acesso em 10/03/2009.

CETESB (2008). Companhia de Tecnologia de Saneamento Ambiental - Hidrologia. Disponível em http://www.cetesb.sp.gov.br/Solo/agua_sub/hidrogeologia.asp. Site visitado em 10/03/2009. Acesso em 10/03/2009.

Chandler, R. J.; Harwood, A. H.; and Skinner, P. J. (1992). Sample disturbance in London Clay. Géotechnique, 42 (4): 577-585.

Coelho Netto, A. L. (1994). Hidrologia de Encosta na interface com a Geomorfologia. In: Guerra, A. J. T. Geomorfologia: uma atualização de bases e conceitos. Rio de Janeiro: Bertrand, Brasil.

Correchel,V. (2003). Avaliação de índices de erodibilidade do solo através da técnica da análise da redistribuição do "Fallout" do ${ }^{137}$ Cs. Tese - Doutorado - Centro de Energia Nuclear na Agricultura, Universidade de São Paulo, Piracicaba - SP. 79p. 
Custódio, G. S.; Vieira, G.S. (2004). Estudo de fatores que influenciam a curva característica de retenção de água no solo. Anais do $5^{\circ}$ Simpósio Brasileiro de Solos Não Saturados, Vol. 1. EESC, USP. São Carlos - SP. 223 - 225.

DAEE (1990). Controle de Erosão. Secretaria de Energia e Departamento de Águas e Energia Elétrica. São Paulo, DAEE/IPT, 2 ed, 92 p.

DAEE (2009). Controle de erosões urbanas. Disponível em: http://www.daee.sp.gov.br/cgibin/carrega.exe?arq=/apoioaomunicipio/cerosao.htm. Acesso em 02/11/2009.

De Campos, T. M. P. (1994). Equipamentos e técnicas para determinação da sucção no campo. $2^{\circ}$ Simpósio sobre solos não saturados, Vol. 1. Recife - PE. 9 - 18.

Denardin, J. E. (1990). Erodibilidade do solo estimada por meio de parâmetros físicos e químicos. Tese de Doutorado - Escola Superior de Agricultura "Luiz de Queiroz", Universidade de São Paulo, Piracicaba - SP. 113p.

Diene, A. A. (2005). Um Novo instrumento para medida de sucção nos solos. Anais da IV Conferência Brasileira Sobre Estabilidade de Encostas, COBRAE, Vol. 1, Salvador - BA, $275-286$.

Dourado Neto, D. (2007). A software to caculate soil hydraulic concuctivity in internal drainage experiments. (SHC, Version 2.00)”. R. Bras. Ci. Solo, 31:1219-1222.

Duarte, U. (1980). Geologia ambiental da área de São Pedro: vetor águas subterrâneas. Tese de doutorado. USP, São Paulo, SP, 66p.

Engler, M. P. C. (2004). Método simples para a determinação da condutividade hidráulica em amostras de solo não-saturadas. Anais do $5^{\circ}$ Simpósio Brasileiro de Solos Não Saturados, Vol. 1. EESC, USP. São Carlos - SP. 39 - 42.

Fácio. J. A. (1991). Proposição de uma metodologia de estudo da erodibilidade dos solos do Distrito Federal. Dissertação de Mestrado - Faculdade de Tecnologia, Universidade de Brasília, Distrito Federal, Brasília. 107p. 
Farias, M. M. (2004). Modelagem constitutiva para o comportamento mecânico de solos não saturados. Anais do $5^{\circ}$ Simpósio Brasileiro de Solos Não Saturados, Vol. 1. EESC, USP. São Carlos - SP. 289 - 297.

Fendrich, R. et al. (1988). Drenagem e controle de erosão urbana. $2^{\mathrm{a}}$ edição. Editora Universitária Champagnat: Curitiba, 442p.

Fernandes, D. O. (2003). Variabilidade dos resultados de ensaios de erodibilidade materiais inconsolidados da Bacia do Ribeirão Samambaia (região de São Pedro, SP). I Simpósio sobre Solos Tropicais e Processos Erosivos no Centro-Oeste. Brasília, 89 - 115.

Ferreira, M. D. (2004). Análise da evolução dos processos erosivosacelerados em áreas urbanas e das técnicas de controle e recuperação - Córrego do Tucum (SÃO PEDRO/SP). Dissertação de Mestrado - Escola de Engenharia de São Carlos, Universidade de São Paulo, São Carlos, 171p.

Feuerharmel, C. (2004). Determinação das curvas características de solos coluvionares pelo uso combinado da placa de sucção e método do papel filtro. Anais do $5^{\circ}$ Simpósio Brasileiro de Solos Não Saturados, Vol. 1. EESC, USP. São Carlos - SP. 243 - 248.

Feuerharmel, C. (2006). The Use of Filter-Paper and Suction-Plate Methods for Determining the Soil-Water Characteristic Curve of Undisturbed Colluvium Soils. Geotechnical Testing Journal, Vol.29, No. 5, 419 - 425.

Fleming, P. M. (1994). Medida de sucção em encostas não saturadas através de tensiômetros automáticos. $2^{\circ}$ Simpósio sobre solos não saturados, Vol. 1. Recife - PE. 79 88.

Fredlund, D. G.; Rahardjo, H. (1993). Soil mechanics for unsaturated soils. New York: John Wiley. 517p.

Fúlfaro, J. V.; Bjomberg, A. J. S. (1993). Geologia. In: Cintra, J. C. A.; Albiero, J. H. Solos do interior de São Paulo. São Carlos, Cap. 1, 01-42.

Fumió, B. L. C. (2004). Solos não saturados e drenagem de camadas próximas da superfície de vias e pavimentos. Tese de Doutorado - Escola de Engenharia de São Carlos, Universidade de São Paulo, São Carlos, 96p. 
Furquim, S. A. C. (2002). Interações entre modelado e solo no transecto espraiado, São Pedro- SP. Dissertação de Mestrado - Faculdade de Filosofia, Letras e Ciências Humanas, Universidade de São Paulo, São Paulo/SP. 146p.

Futai, M. M. et al. (2005). Evolução de uma voçoroca por escorregemantos retrogressivos em solo não-saturado. Anais da IV Conferência Brasileira Sobre Estabilidade de Encostas, COBRAE, Vol. 1, Salvador - BA, 4443 - 452.

Gehling, W. Y. Y. (2004). Ensaios de laboratório e de campo. Anais do $5^{\circ}$ Simpósio Brasileiro de Solos Não Saturados, Vol. 2. EESC, USP. São Carlos - SP. 513 - 523.

Gerscovich, D. M. S. (2004). Avaliação das relações de condutividade hidráulica em solos brasileiros não saturados. Anais do $5^{\circ}$ Simpósio Brasileiro de Solos Não Saturados, Vol. 1. EESC, USP. São Carlos - SP. 249 - 254.

Gomes, J. E. S. (2007). Estudo sobre fatores que influenciam a acurácia do método do papel-filtro. Dissertação de Mestrado - Escola Politécnica, Universidade de São Paulo, São Paulo/SP. 95p.

Gruber, G. A. G et al. (1995). Carta de erodibilidade da Folha de Cosmópolis, São Paulo: auxílio ao gerenciamento do meio físico. Revista do Instituto Geológico, vol. Especial, p.5764

Guimarães, C. N. (2008). Mapeamento geotécnico da Bacia Córrego da Barra, aplicação do penetrômetro de impacto em estudos de processos erosivos São Pedro - SP, Escala 1:10.000. Dissertação de Mestrado - Escola de Engenharia de São Carlos, Universidade de São Paulo, São Carlos, 108p.

Hernandez Moncada, M. P. (2004). Determinação de relações umidade - sucção de um solo laterítico submetido à contaminação com licores cáusticos. Anais do $5^{\circ}$ Simpósio Brasileiro de Solos Não Saturados, Vol. 1. EESC, USP. São Carlos - SP. 267 - 271.

Ide, D. M. (2009). Investigação geotécnica e estudo de um processo erosivo causado por ocupação urbana. Dissertação de Mestrado - Escola de Engenharia de São Carlos, Universidade de São Paulo, São Carlos. 
Indraratna, B. (1991). Erosion of dispersive soils in Northeast Thailand. Geotechnical Engineering, Vol. 22, Photographic feature.

Iwata, S; Tabuchi, T. \& Warkentin, B. P. (1988). Soil-water interactions. Mechanisms and Applications. Ed. Marcel Dekker, New York. 380 p.

Jucá, J. F. T. (1990). Variação de umidade em solos parcialmente saturados com sucção controlada. Anais do $6^{0} \mathrm{CBGE}$, IX COBRAMSEF. Vol. 1. Salvador, Bahia. 363 - 369.

Lafayette, K. P. V. et al. (2005). Avaliação da erodibilidade como parâmetro no estudo de sulcos e ravinas uma encosta no Cabo de Santo Agostinho - PE. Anais da IV Conferência Brasileira Sobre Estabilidade de Encostas, COBRAE, Vol. 1, Salvador - BA, 387 - 400

Leong, E. C.; Tripathy, S. \& Rahardjo, H. (2003). Total suction measurement of unsaturated soils with a device using the chilled-mirror dew-point technique. Géotechnique 53, No. 2, 173-182.

Lima, M. C. (2003). Degradação físico-química e mineralógica de maciços junto às voçorocas. Tese de Doutorado - Departamento de Engenharia Civil e Ambiental. Brasília: FT, UNB, 150p.

Lobo, A. S. (1997). Problemas de fundações em solo colapsível - Estudo de casos. Anais do $3{ }^{\circ}$ Simpósio Brasileiro de Solos Não Saturados. Vol.1, Rio de Janeiro - RJ. 77 - 89.

Lougon-Duarte, A. P. (2004). Efeitos da temperatura na relação umidade-sucção de dois solos. Anais do $5^{\circ}$ Simpósio Brasileiro de Solos Não Saturados, Vol. 1. EESC, USP. São Carlos - SP. $235-242$.

Machado, S. L. (1998). Aplicação de conceitos de elastoplasticidade a solos não saturados. Tese de Doutorado, EESC - USP, São Carlos, 1998. 360 p.

Machado, S. L. \& Zuquette, L. V. (2004). Transporte de massa e mecanismos de retenção em solos não saturados. Anais do $5^{\circ}$ Simpósio Brasileiro de Solos Não Saturados, Vol. 2. EESC, USP. São Carlos - SP. 545 - 574. 
Mahler, C. F. (2004). Desenvolvimento de um tensiômetro para medições de sucções Elevadas. Anais do $5^{\circ}$ Simpósio Brasileiro de Solos Não Saturados, Vol. 1. EESC, USP. São Carlos - SP. $69-72$.

Mahler, C. F. (2005). Um Novo Instrumento para Medida de Sucção nos Solos. Solos e Rochas, São Paulo, 28, (3): 309-318, Setembro-Dezembro.

Martins, F. B. (1997). Comportamento em condições edométricas de um solo residual de arenito. Anais do $3^{\circ}$ Simpósio Brasileiro de Solos Não Saturados. Vol.1, Rio de Janeiro - RJ. 121-130.

Marinho, F. A. M. (1997). Medição de sucção em solos. Anais do $3^{\circ}$ Simpósio Brasileiro de Solos Não Saturados. Vol. 2, Rio de Janeiro - RJ. 373 - 397.

Marinho, F. A. M. (2006). The Filter Paper Method Revisited. Geotechnical Testing Journal, Vol. 29, $\mathrm{n}^{\mathrm{o}} 3,250-258$, may.

Medeiros, G. A. de (2001). Influência da compactação do solo sobre a condutividade hidráulica saturada para um solo argiloso. Rev. Ecossistema, Vol. 26, nº 2, ago - dez.

Mio, G. et al. (1995). Cartografia geotécnica da região de Mogi-Guaçu, São Paulo. Revista do Instituto Geológico, vol. especial, p.99-105.

Miranda, J. G. de (2005). Mapeamento geotécnico e estudo da susceptibilidade à erosão na bacia do Ribeirão Ponte de Pedra (MT), escala: 1:100.000. Tese de Doutorado - Escola de Engenharia de São Carlos, Universidade de São Paulo, São Carlos, 273p.

Molinari, D. C. (2005). Infiltração de água e deslizamentos em encostas: o caso da Fazenda Caipuru - Presidente Figueiredo - AM. Anais da IV Conferência Brasileira Sobre Estabilidade de Encostas, COBRAE, Vol. 1, Salvador - BA, 431 - 441.

Moraes, S. O.; Libardi, P. L. (1993). Problemas metodológicos na obtenção da curva de retenção da água pelo solo. Sci. Agric., Piracicaba, 50 (3): 383 - 392, out./dez. Disponível em: http://www.scielo.br/pdf/sa/v50n3/10.pdf.

Mortari, D. (1994). Caracterização Geotécnica do Processo Evolutivo das Erosões no Distrito Federal. Dissertação de Mestrado em Geotecnia - UNB, Brasília, 217 p. 
Mota, F. S.; Ferreira, M. D; Pejon, O. J. (2007). Análise das relações entre absorção de água e condutividade hidráulica dos solos em estudos de erosão. Relatório de Iniciação Científica - CNPQ, São Carlos, 2007.

Mota, F.S. (2008). Análise das relações entre fenômenos hídricos e da influência da variação da umidade no comportamento dos solos em estudos de erosão. Monografia (Graduação em Engenharia Ambiental). Escola de Engenharia de São Carlos, USP, 2008.

Motta, N. O. da (2001). Caracterização geotécnica e dos processos erosivos na cidade de Campo Grande - MS. Dissertação de Mestrado, Publicação G.DM - 077A/01, Departamento de Engenharia Civil e Ambiental - UNB, Brasília/DF. 179p.

Naime, J. M. (2001). Um novo método para estudos dinâmicos, in situ, da infiltração da água na região não saturada do solo. Tese de Doutorado - Escola de Engenharia de São Carlos, Universidade de São Paulo, São Carlos, 140p.

Netto, A. A. (2004). Novos métodos e equipamentos para caracterização física dos solos. Anais do $5^{\circ}$ Simpósio Brasileiro de Solos Não Saturados, Vol. 1. EESC, USP. São Carlos SP. $3-8$.

Nishiyama, L. (1991). Mapeamento geotécnico preliminar da quadricula de Sao Carlos SP. Dissertação de Mestrado. Universidade de São Paulo, São Carlos, 228p.

Nogami, J. S.; Villibor, D. F. (1979). Soil characterization of mapping units for highway purposes in a tropical área. Bulletin of Engineering Geology and the Environment, Vol. 19, 196-199.

Oliveira, D. (1997). Estudo macro e micromorfológico de uma topossequência na Bacia do Córrego do Retiro em São Pedro - SP. Dissertação de Mestrado. FFLCH - USP, São Paulo, 143p.

Oliveira, D. R. (2004). Influência das proprieddes hidráulicas na evaporação de solos colapsíveis não saturados. Anais do $5^{\circ}$ Simpósio Brasileiro de Solos Não Saturados, Vol. 1. EESC, USP. São Carlos - SP. 161 - 167.

Oliveira, J. B. \& Caruso, L. G. (1981). Contribuição ao conhecimento atual de características tecnológicas de rochas sedimentares em alguns estados brasileiros. Anais 
do $3^{\circ}$ Congresso Brasileiro de Geologia de Egenharia, ABGE, Itapema, SP, v. 3 pp. 221 233.

Oliveira, J. B. (1992). Classes Gerais de Solos do Brasil. 2 ed. Jaboticabal, FUNEP, São Paulo, 201p.

Oliveira A.M.S; Brito, S.N.A. (1998). Geologia de Engenharia. São Paulo: ABGE. 586p.

Palma, J. B. (2004). Avaliação da condutividade hidráulica em solos, não-saturados, com diferentes tipos de usos - Bacia Hidrográfica do Córrego Vaçununga, (Luis Antônio SP). Anais do $5^{\circ}$ Simpósio Brasileiro de Solos Não Saturados, Vol. 1. EESC, USP. São Carlos $-\mathrm{SP}$

Pejon, O. J. (1992). Mapeamento Geotécnico da folha de Piracicaba-SP (escala 1:100.000): estudo de aspectos metodológicos, de caracterização e de apresentação dos atributos. Tese de Doutorado - Escola de Engenharia de São Carlos, Universidade de São Paulo, São Carlos, 224p.

Pejon, O. J.; Silveira, L. L. L. (2006). Index properties to predict erodibility of tropical soil. In: Bull Eng Geol Environ 66. 2006. p. 225-236.

Pereira, E. M. (2004). Estudo do comportamento à expansão dos materiais da formação Guabirotuba em ensaios com sucção controlada. Tese de Doutorado - Escola de Engenharia de São Carlos, Universidade de São Paulo, São Carlos, 24-105.

Pereira et al. (2003). Análise do desempenho de um novo modelo físico para o ensaio de Inderbitzen. I Simp6sio sobre Solos Tropicais e Processos Erosivos no Centro-Oeste, UNB, Brasília. $109-115$.

Pereira,V. P. (1994). Solos altamente suscetíveis à erosão. Jaboticabal, FCAVUNESP/SBCS. 253p.

Pinto, C. S. (1991). Aulas de Mecânica dos solos. Escola Politécnica da USP, São Paulo.

Porras Ortiz, O. F. (2004). Comportamento mecânico de materiais particulados não saturados - determinação da rigidez em equipamento triaxial verdadeiro sob sucção 
controlada. Anais do $5^{\circ}$ Simpósio Brasileiro de Solos Não Saturados, Vol. 1. EESC, USP. São Carlos - SP. $95-101$.

Presa, E. P. (1988). Metodologias empregadas no estudo do comportamento geotécnico dos solos não saturados. Simpósio sobre novos conceitos em ensaios de campo e laboratório em Geotecnia, Vol. 1, Rio de Janeiro, RJ. 25 - 48.

Presa, E. P. (1994). Análise das trajetórias de sucção-umidade de um solo residual de granulito. $2^{\circ}$ Simpósio sobre solos não saturados, Vol. 1. Recife - PE. 203 - 210.

Queiroz, M. M. F. (1999). Estudo da condutividade hidráulica de um solo aluvial em lisímetros. Rev. Brasileira de Engenharia Agrícola e Ambiental, v.3, n.2, p.161-166. Campina Grande, PB, DEAg/UFPB.

Reichardt, K. (1993). Estimativa de fluxos de água em solos não saturados. Rev. Bragantia, Campinas, 52 (1): $83-87$.

Reichardt, K. (1990). A água em sistemas agrícolas. Editora Manole LTDA. São Paulo, Brasil. 188 p.

Richards, L. A. (1928). The usefulness of capillary potential to soil-moisture and plant investigators. Journal of the Agricultural Research. Washington, 37 (12).

Rodrigues, J. E. (1982). Estudo de fenômenos erosivos acelerados: boçorocas. Tese de Doutorado - Escola de Engenharia de São Carlos, Universidade de São Paulo, São Carlos.

Rodrigues, J. E.; Zuquette, L. V.; Gandolfi, N. (1993). Mapeamento geotécnico da região centro-leste do Estado de São Paulo. In: CINTRA, J. C. A.; ALBIERO, J. H. Solos do interior de São Paulo. São Carlos, Cap. 2, 43-58.

Rodrigues, R. A. (2007). Modelação das deformações por colapso devidas à ascensão de lençol freático. Tese de Doutorado - Escola de Engenharia de São Carlos, Universidade de São Paulo, São Carlos.

Röhm, S. A. (1992). Resistência ao cisalhamento de um solo arenoso laterizado não saturado da região de São Carlos - SP. São Carlos, 274p. Tese (Doutorado em Geotecnia). Escola de Engenharia de São Carlos, Universidade de São Paulo. 
Röhm, S. A. (2004). Solos Não Saturados. Monografia Geotécnica n ${ }^{\circ} 4$. Departamento de Geotecnia, EESC, USP. São Carlos - SP, 135p.

Rufino, R. L. (1986). Avaliação do potencial erosivo da chuva para o Estado do Paraná: segunda aproximação. R. bras. Ci, Solo, 10:279-281.

Santos, C. R. (2004). Análise paramétrica da estabilidade de taludes em solos não saturados: a influência do tipo de solo. Anais do $5^{\circ}$ Simpósio Brasileiro de Solos Não Saturados, Vol. 1. EESC, USP. São Carlos - SP. 181 - 188.

Saramago, R. P. (1997). Influência da constante dielétrica no comportamento dos solos colapsíveis. Anais do $3^{\circ}$ Simpósio Brasileiro de Solos Não Saturados. Rio de Janeiro - RJ. 6570 .

Silva, A. F. (2003). Mapeamento geotécnico e análise dos processos erosivos na Bacia do Córrego Tuncum, São Pedro-SP, Escala 1:10.000. Dissertação de Mestrado - Escola de Engenharia de São Carlos, Universidade de São Paulo, São Carlos, 117p.

Silva, A. M. (2005). Banco de dados de curvas de retenção de água de solos brasileiros. Dissertação de Mestrado - Escola de Engenharia de São Carlos, Universidade de São Paulo, São Carlos, 116p.

Silva, E. P. et al. (2005). Quantificação da evolução de erosões em encostas - Caso de santo Agostinho - PE. Anais da IV Conferência Brasileira Sobre Estabilidade de Encostas, COBRAE, Vol. 1, Salvador - BA, $241-252$.

Silva, I. de F. (1986). Erodibilidade de seis solos do semi-árido paraibano obtida com chuva simulada e método Nomográfico. R. bras. Cio Solo, 10:283-287.

Silveira, A. (1993). Infiltração e armazenamento no solo. In: Tucci, C. Hidrologia: ciência e aplicação. Porto Alegre: Ed. Universidade, ABRH, EDUSP.

Silveira, L. L. L. (2002). Elaboração da carta de suscetibilidade à erosão da Bacia dos Rios Araraquara e Cubatão - SP, Escala 1:50.000. Dissertação de Mestrado - Escola de Engenharia de São Carlos, Universidade de São Paulo, São Carlos, 195p. 
Soto, M. A. A. (2004). Comparação entre métodos de imposição e de controle de sucção em ensaios com solos não saturados. Tese de Doutorado - Escola de Engenharia de São Carlos, Universidade de São Paulo, São Carlos, 194p.

Soto, M. A. A. \& VILAR, O. M. (2004). Geometria factral na determinação da curva de retenção de água no solo. Anais do $5^{\circ}$ Simpósio Brasileiro de Solos Não Saturados, Vol. 1. EESC, USP. São Carlos - SP. 203 - 208.

Tãvora, M. R. P. (1985). Erodibilidade de dois solos da região de Ibiapaba, Estado do Ceará. R. Bras. Ci. Solo, 9:59 - 62.

Teixeira et al. (2003). Decifrando a Terra. 2 ed, Oficina de Textos, São Paulo - SP, Caps. 7 e $8,568 p$.

Tolentino, M. (1967). Estudo crítico sobre o clima de São Carlos. São Carlos: S.N., 78p.

Van Genuchten, M. T. (1980). A closed form equation for predicting the hydraulic conductivity of unsaturated soils. Soil Science Society of America Journal, Madison, v.44, p.892-898.

Velozo, R. (2006). Caracterização geológico-geotécnica do lixão desativado de São Carlos - SP, com auxílio da geofísica. Dissertação de Mestrado - Escola de Engenharia de São Carlos, Universidade de São Paulo, São Carlos, 138p.

Vertamatti, E. (1990). Um estudo da erodibilidade de solos tropicais. Anais do $6^{0} \mathrm{CBGE}$, IX COBRAMSEF. Vol. 1. Salvador, Bahia. 363 - 369.

Viana, R. F. (2002). Parâmetros de erosão e geotécnicos de solos da Bacia das Codornas. Geotecnia n 94 - Mar. $79-91$.

Vieira, S. R. (1987). Determinação, em laboratório, de curvas de retenção de água com tensiômetros. R. bras. Ci. Solo, v.11 :87-90.

Vilar, O. M. (1987). Formulação de um modelo matemático para a erosão dos solos pela chuva. Tese de Doutorado - Escola de Engenharia de São Carlos, Universidade de São Paulo, São Carlos, 196p. 
Vilar, O. M.; Prandi, E. C. (1993). Erosão dos solos. In: Cintra, J. C. A.; Albiero, J. H. "Solos do interior de São Paulo". São Carlos, Cap. 7, 177.206.

Vilar, O. M. (2000). Notas de aula. Departamento de Geotecnia. EESC, USP. São Carlos, SP. Vilar, O. M. (2004). Prefácio dos Anais do Simpósio Brasileiro de Solos Não Saturados, Vol. 1. EESC, USP. São Carlos - SP.

Wolle, C. M. (1988). Medidas in situ de tensões de sucção. Simpósio sobre novos conceitos em ensaios de campo e laboratório em Geotecnia, Vol. 1, Rio de Janeiro, RJ. 645 - 665.

Zuquette, L. V. et al. (1995). Mapeamento geotécnico da cidade de Franca (SP), Brasil Escala 1:25.000: Carta de risco à erosão. Geociências, v.14, n.2, p.41-58.

Zuquette, L. V. (1981). Mapeamento geotécnico preliminar na região de São Carlos. Dissertação de Mestrado - EESC/USP. São Carlos - SP, 86p. 
ANEXO 1 - Curvas de Absorção de água $\left(q \times t^{0.5}\right)$ do Solo 1 geradas após ensaios de laboratório com sucção controlada. 
Curvas plotadas a partir de valores médios $q\left(\mathrm{~cm}^{3} / \mathrm{cm}^{2}\right)$ em função do tempo e adotandose critérios diferentes para as linhas de tendência.

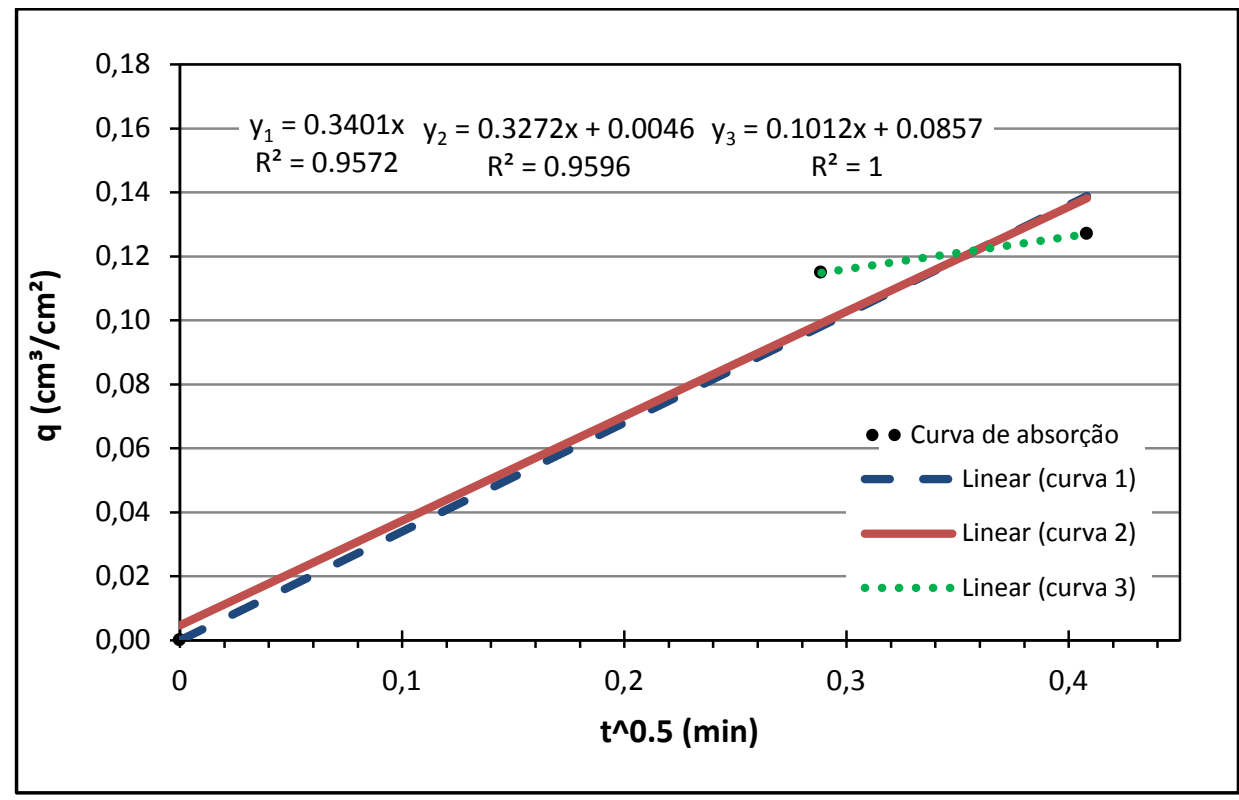

Figura 61 - Curvas de absorção de água - Solo $1[S=2 \mathrm{kPa}]$

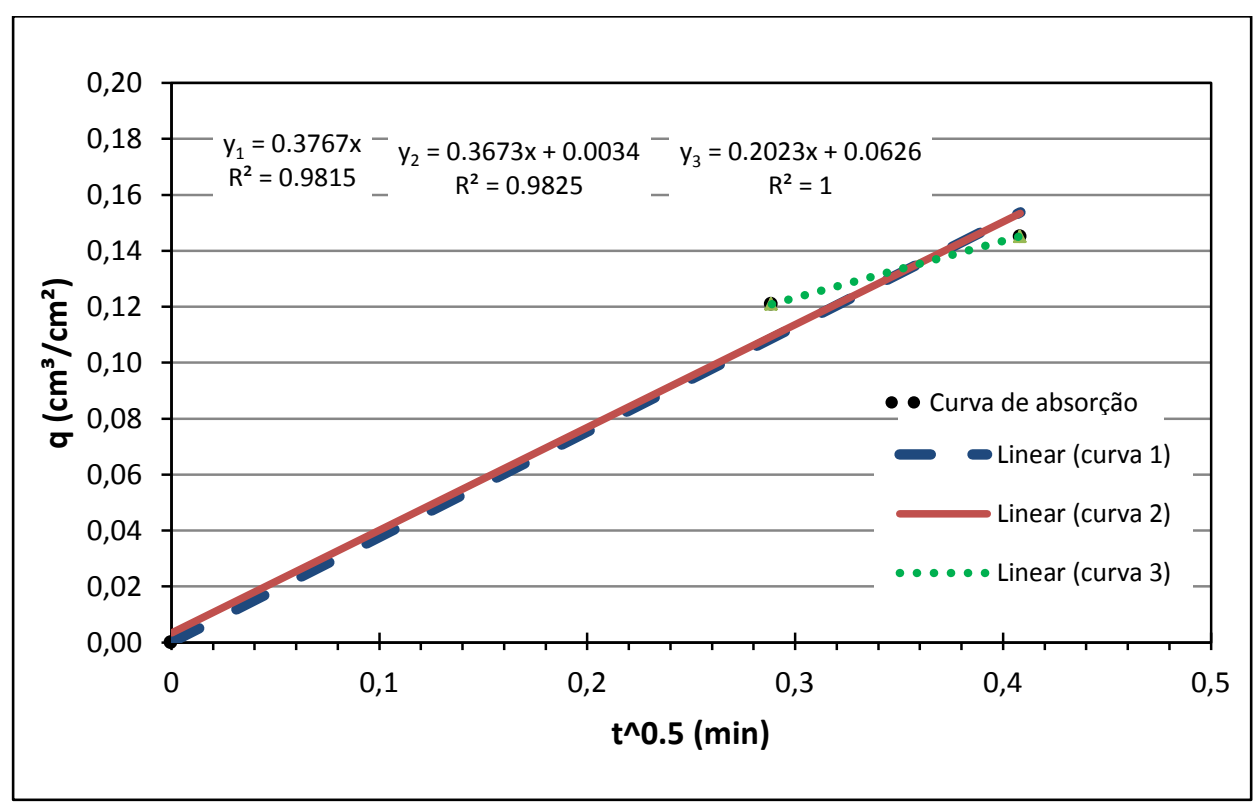

Figura 62 - Curvas de absorção de água - Solo $1[S=5 \mathrm{kPa}]$ 


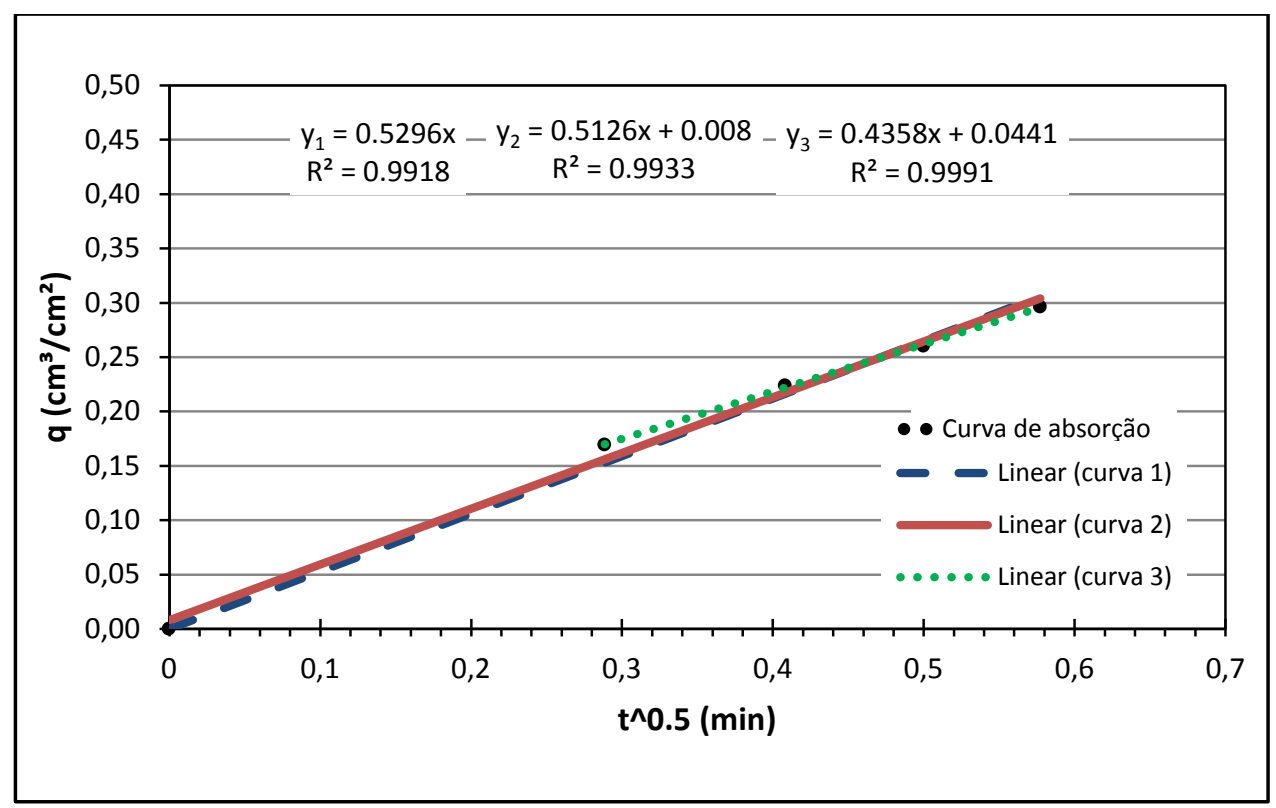

Figura 63 - Curvas de absorção de água - Solo 1 [S = $10 \mathrm{kPa}]$

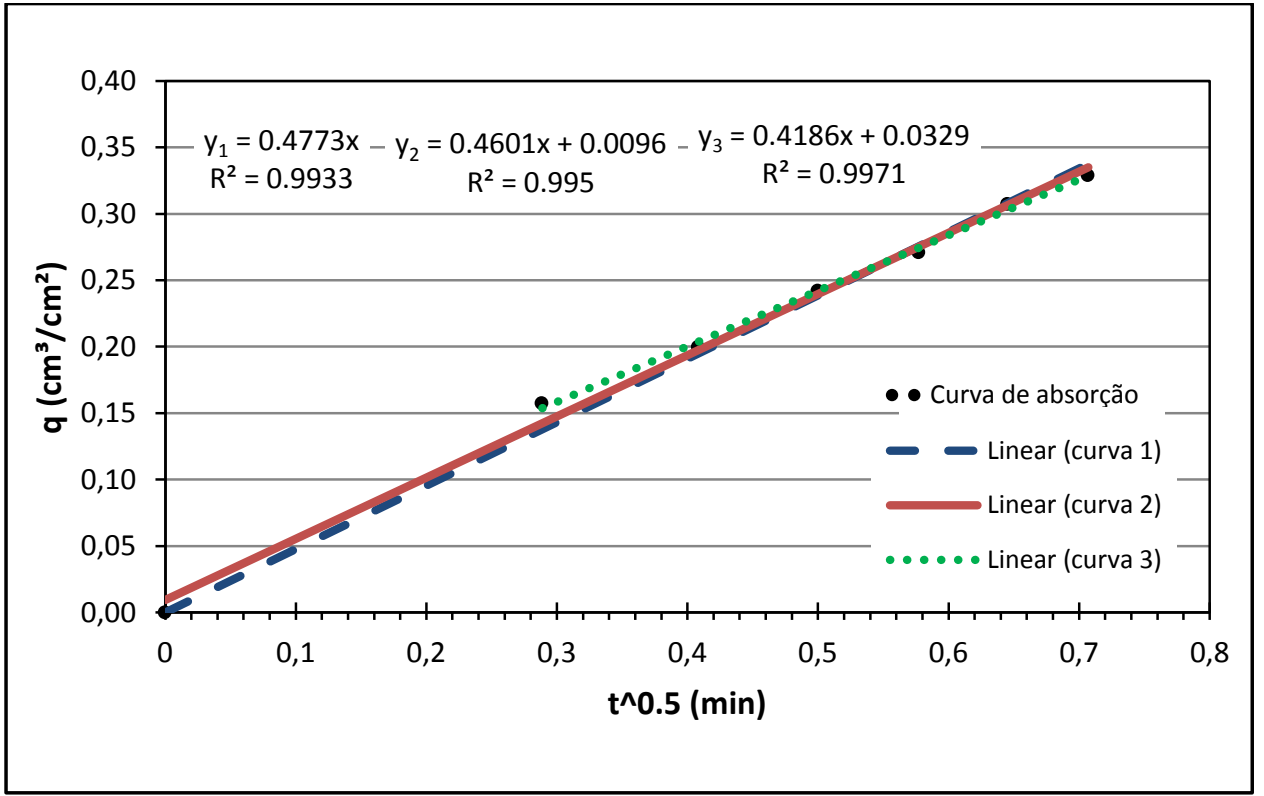

Figura 64 - Curvas de absorção de água - Solo 1 [S = $20 \mathrm{kPa}$ ] 


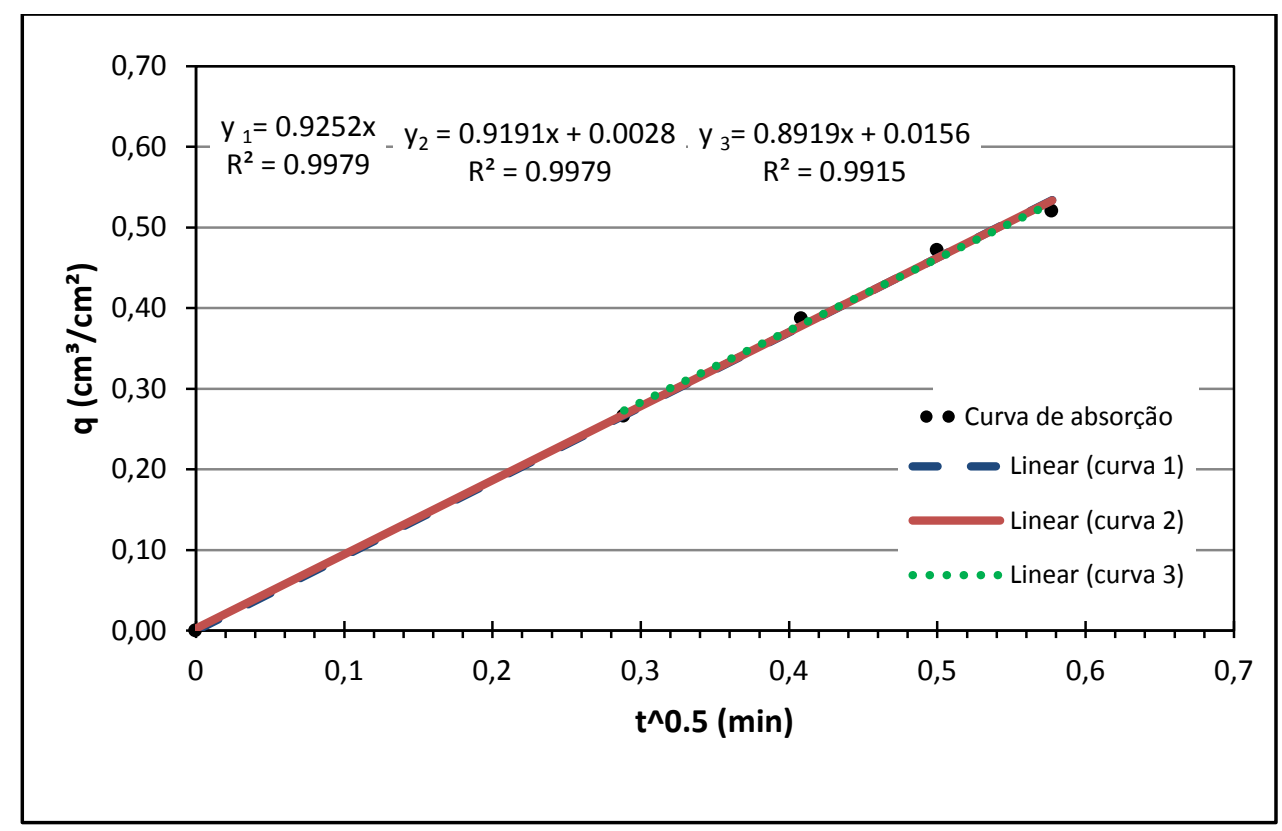

Figura 65 - Curvas de absorção de água - Solo 1 [S = 100 kPa]

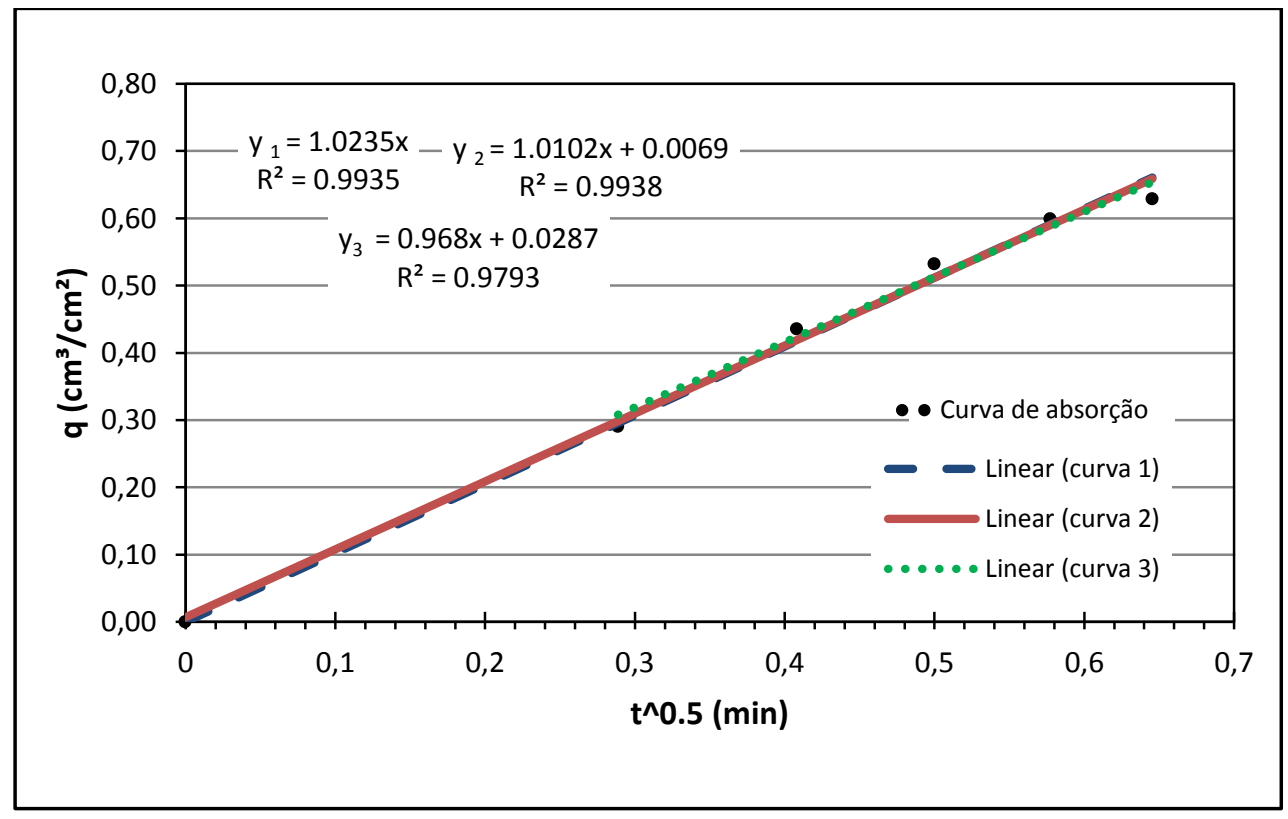

Figura 66 - Curvas de absorção de água - Solo $1[S=200 \mathrm{kPa}]$ 


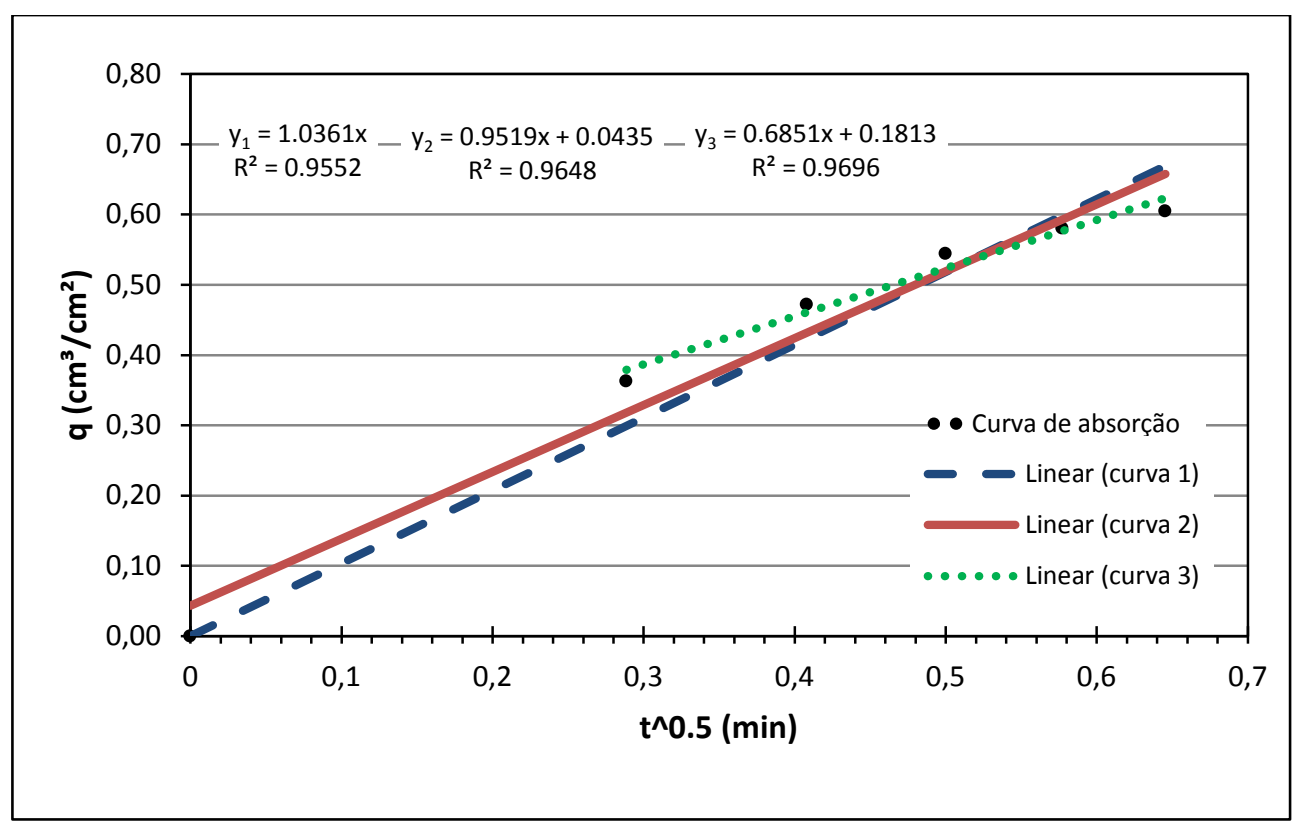

Figura 67 - Curvas de absorção de água - Solo 1 [S = 500 kPa]

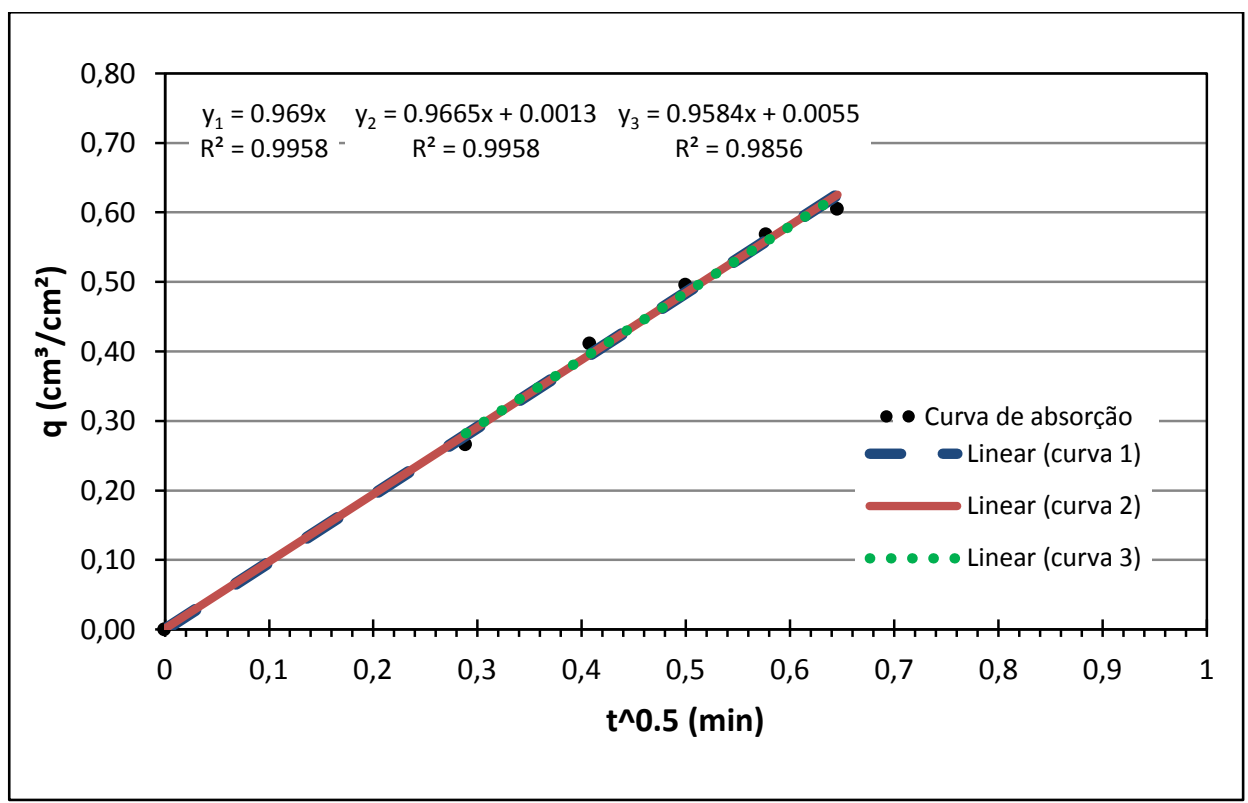

Figura 68 - Curvas de absorção de água - Solo $1[S=800 \mathrm{kPa}]$ 


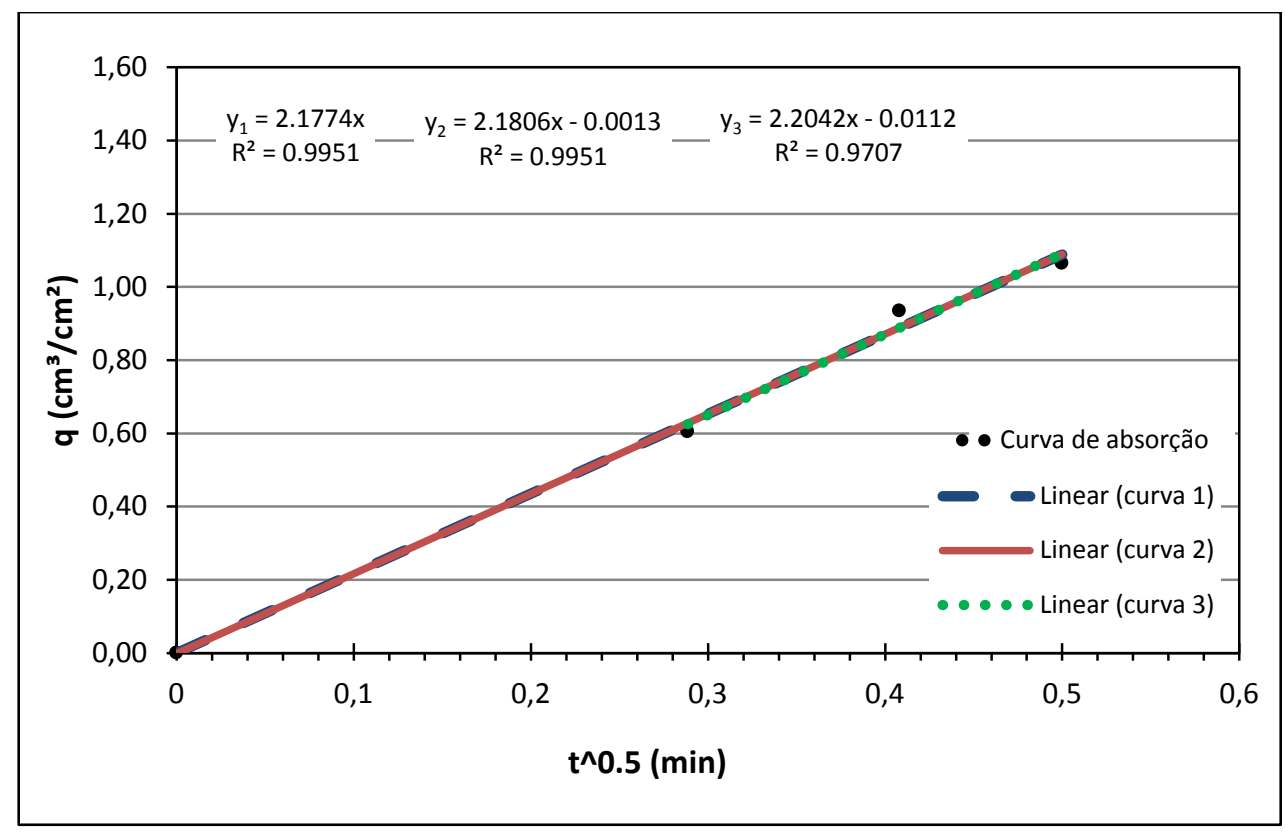

Figura 69 - Curvas de absorção de água - Solo 1 (amostras secas ao ar) - [S>800 kPa] 
ANEXO 2 - Curvas de Absorção de Água $\left(q \times t^{0.5}\right)$ do Solo 2 geradas após ensaios de laboratório com sucção controlada. 
Curvas plotadas a partir de valores médios $q\left(\mathrm{~cm}^{3} / \mathrm{cm}^{2}\right)$ em função do tempo e adotandose critérios diferentes para as linhas de tendência.

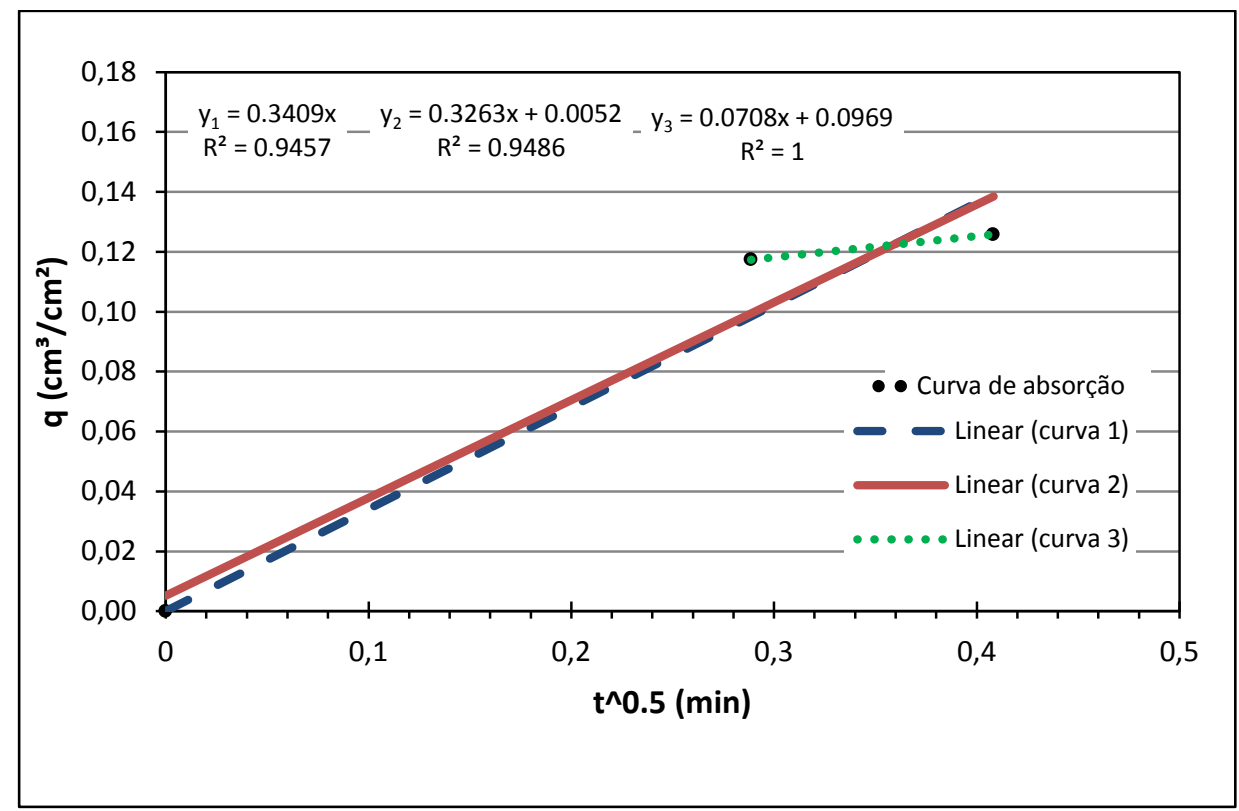

Figura 70 - Curvas de absorção de água - Solo $2[S=2 \mathrm{kPa}]$

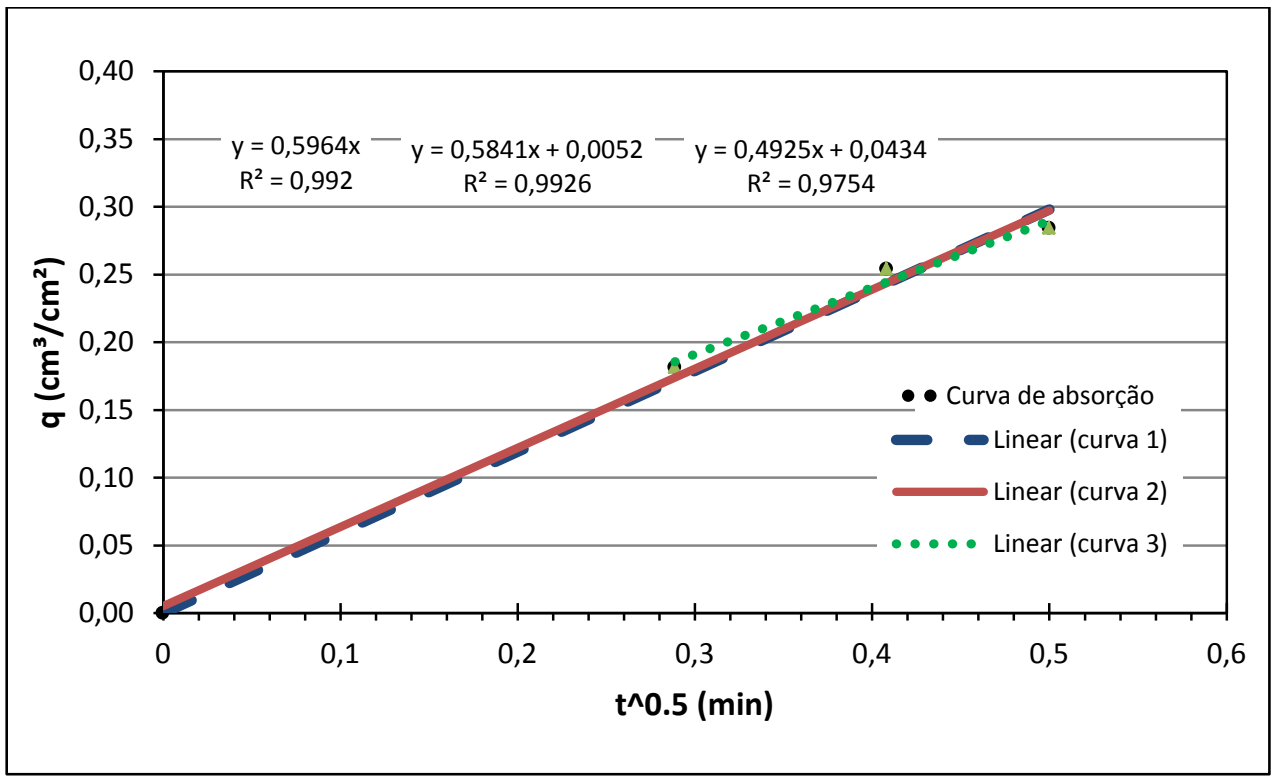

Figura 71 - Curvas de absorção de água - Solo $2[S=5 \mathrm{kPa}]$ 


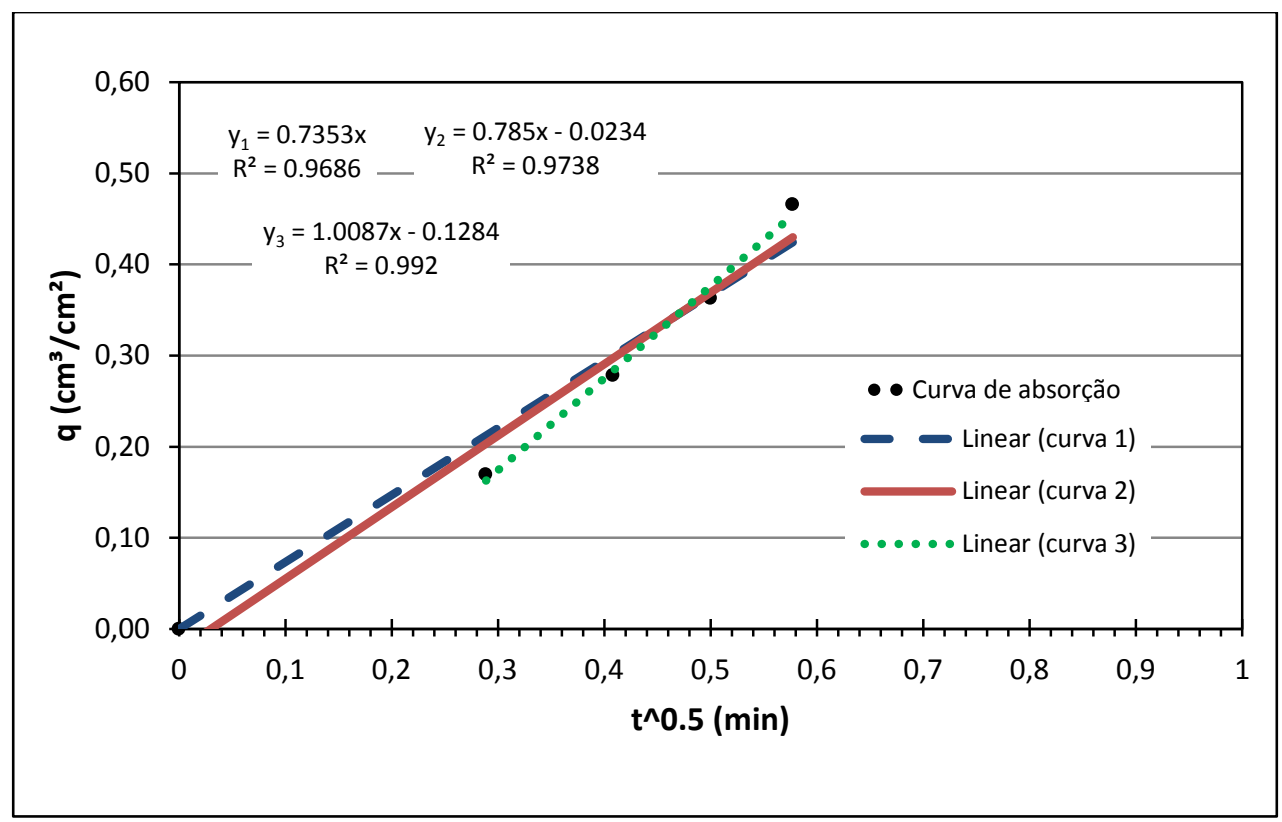

Figura 72 - Curvas de absorção de água - Solo 2 [S = $10 \mathrm{kPa}$ ]

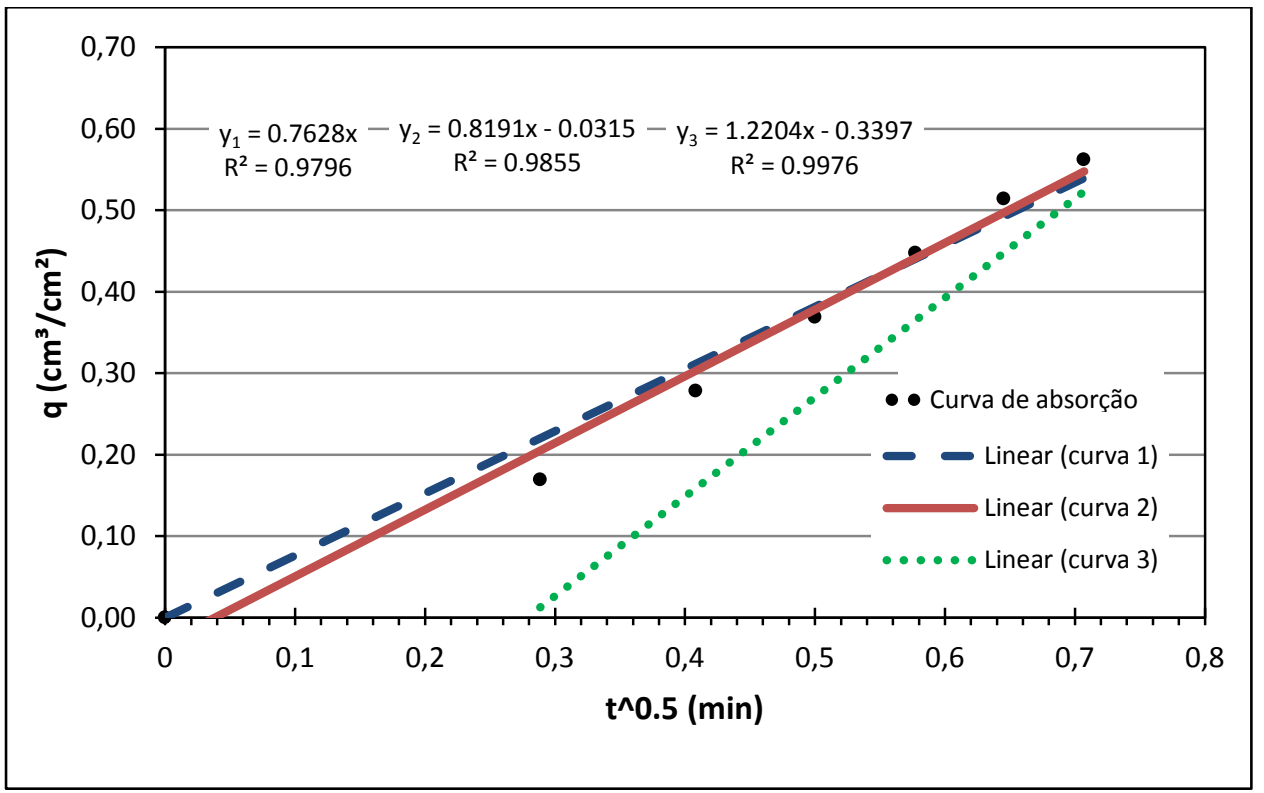

Figura 73 - Curvas de absorção de água - Solo $2[S=20 \mathrm{kPa}]$ 


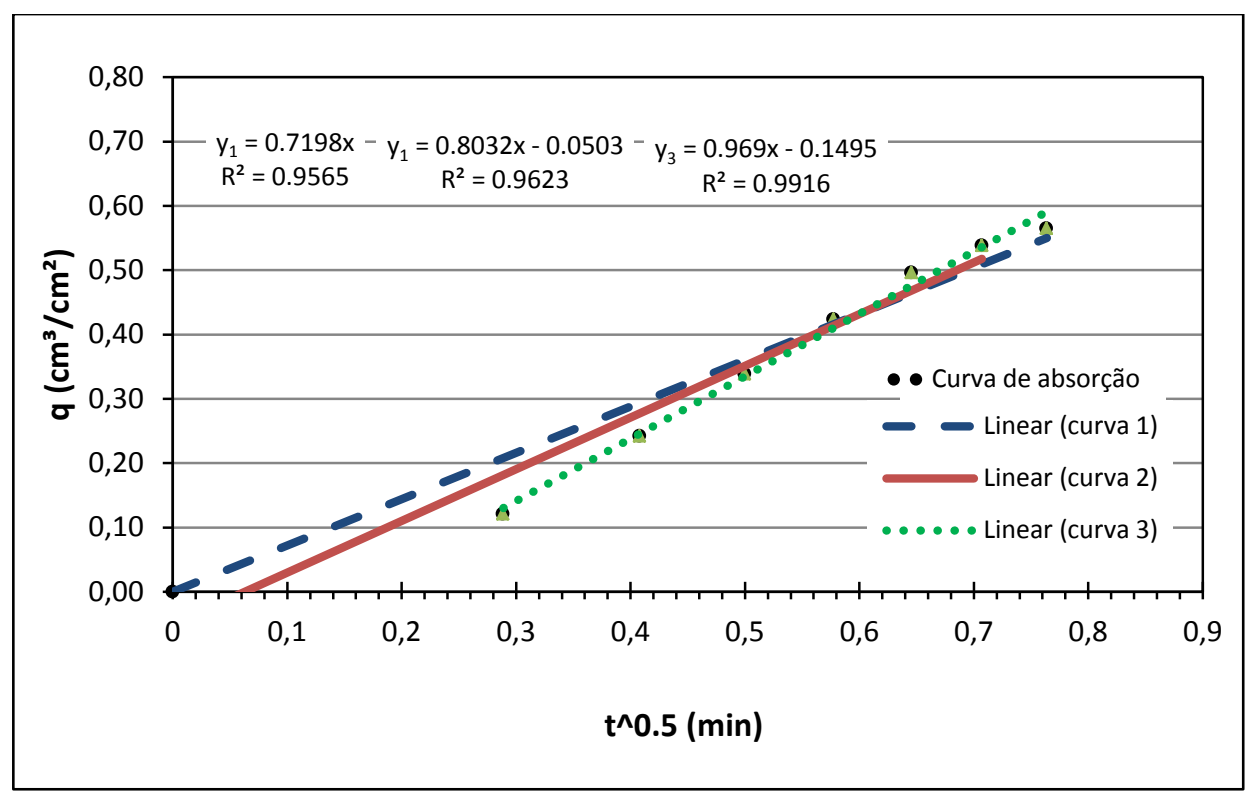

Figura 74 - Curvas de absorção de água - Solo $2[S=100 \mathrm{kPa}]$

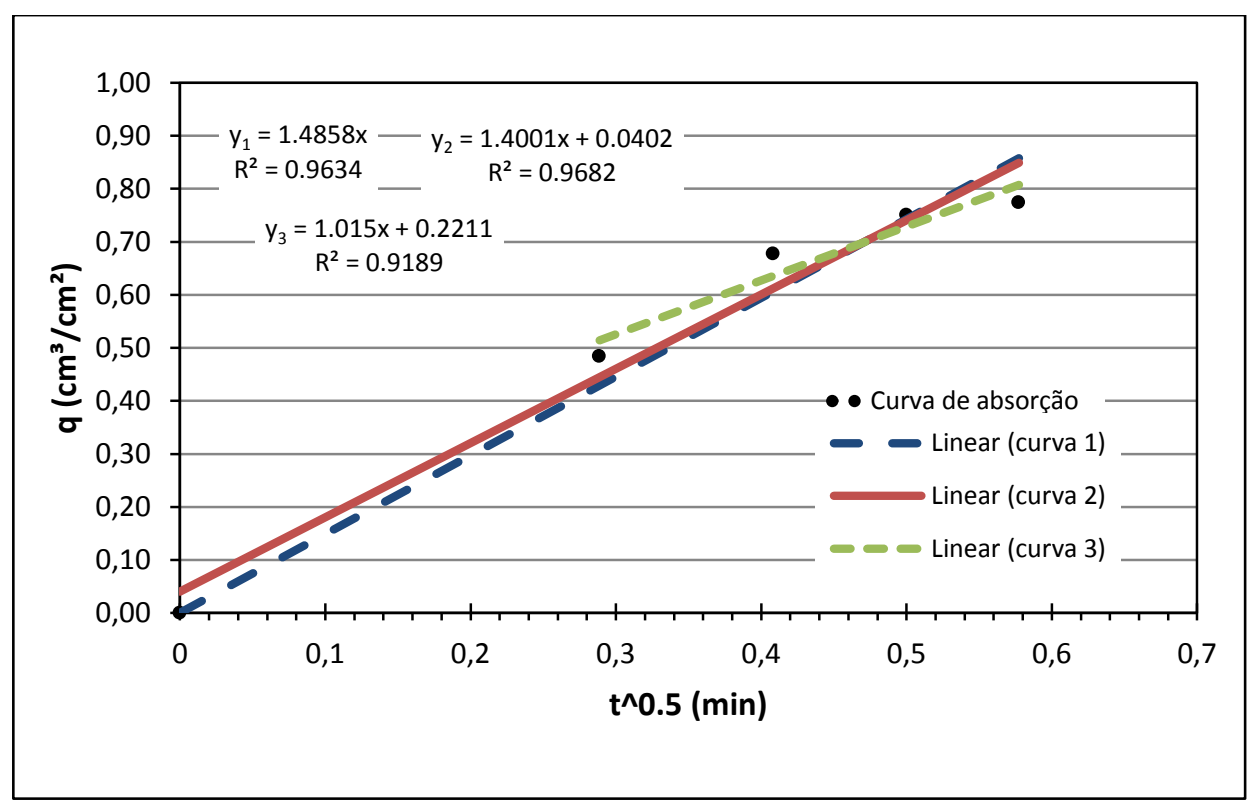

Figura 75 - Curvas de absorção de água - Solo $2[S=200 \mathrm{kPa}]$ 


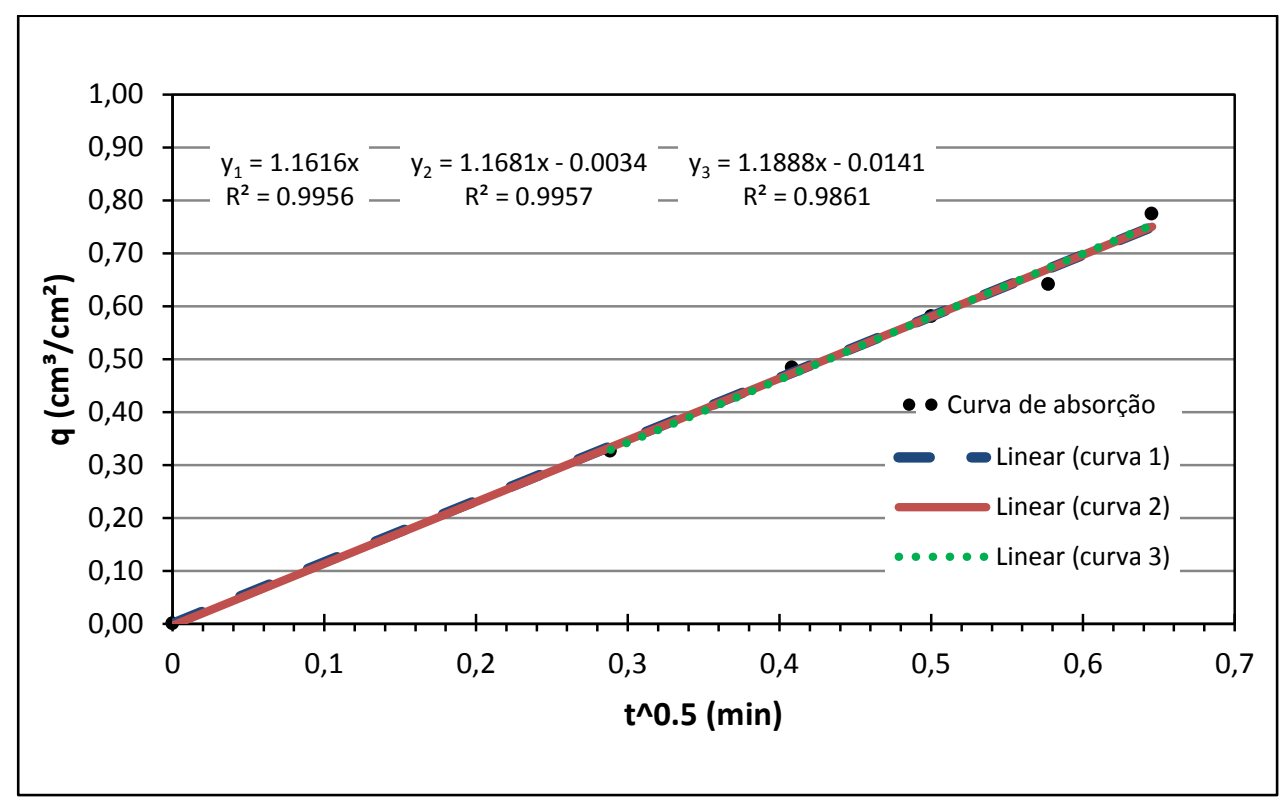

Figura 76 - Curvas de absorção de água - Solo $2[S=500 \mathrm{kPa}]$

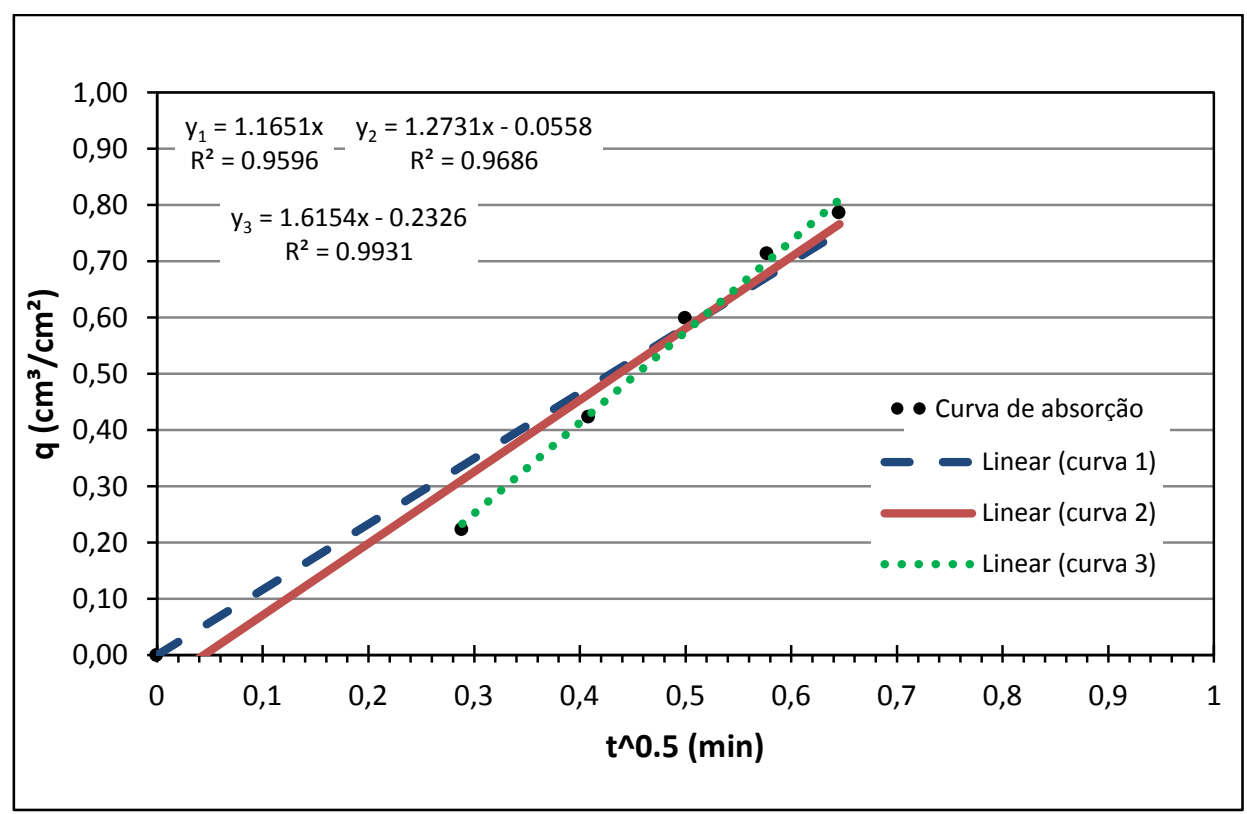

Figura 77 - Curvas de absorção de água - Solo $2[\mathrm{~S}=800 \mathrm{kPa}]$ 


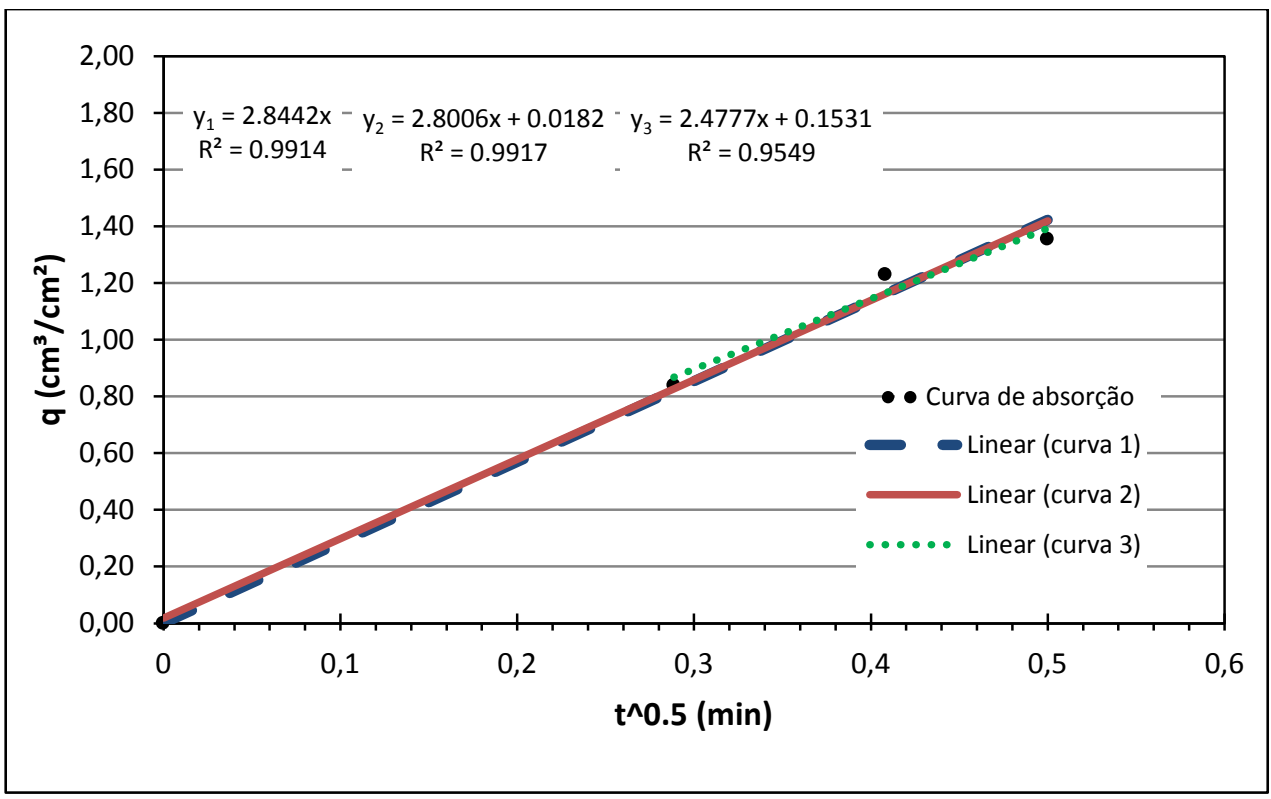

Figura 78 - Curvas de absorção de água - Solo 2 (amostras secas ao ar) - [S > $800 \mathrm{kPa}]$ 


\section{ANEXO 3 - Curvas de Absorção de Água $\left(q \times t^{0.5}\right)$ do Solo 3 geradas após ensaios de laboratório com sucção controlada.}


Curvas plotadas a partir de valores médios $q\left(\mathrm{~cm}^{3} / \mathrm{cm}^{2}\right)$ em função do tempo e adotandose critérios diferentes para as linhas de tendência.

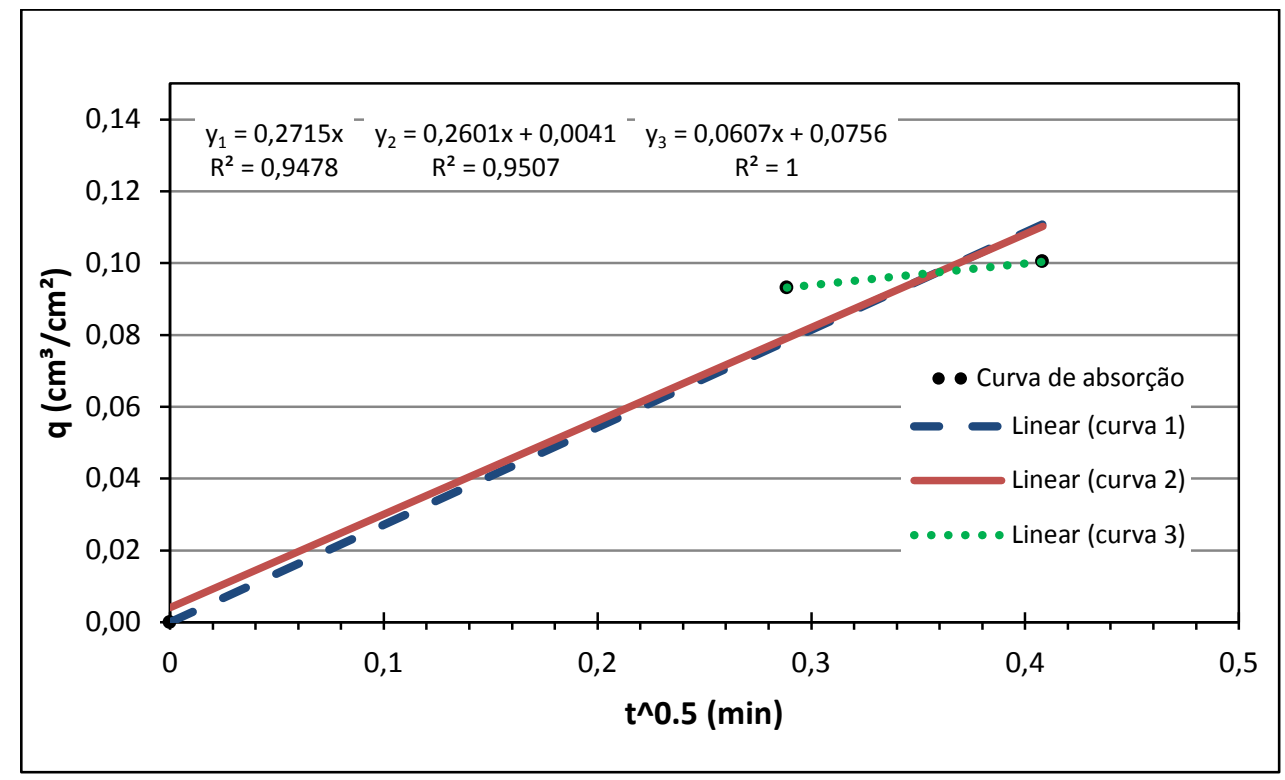

Figura 79 - Curvas de absorção de água - Solo $3[S=2 \mathrm{kPa}]$

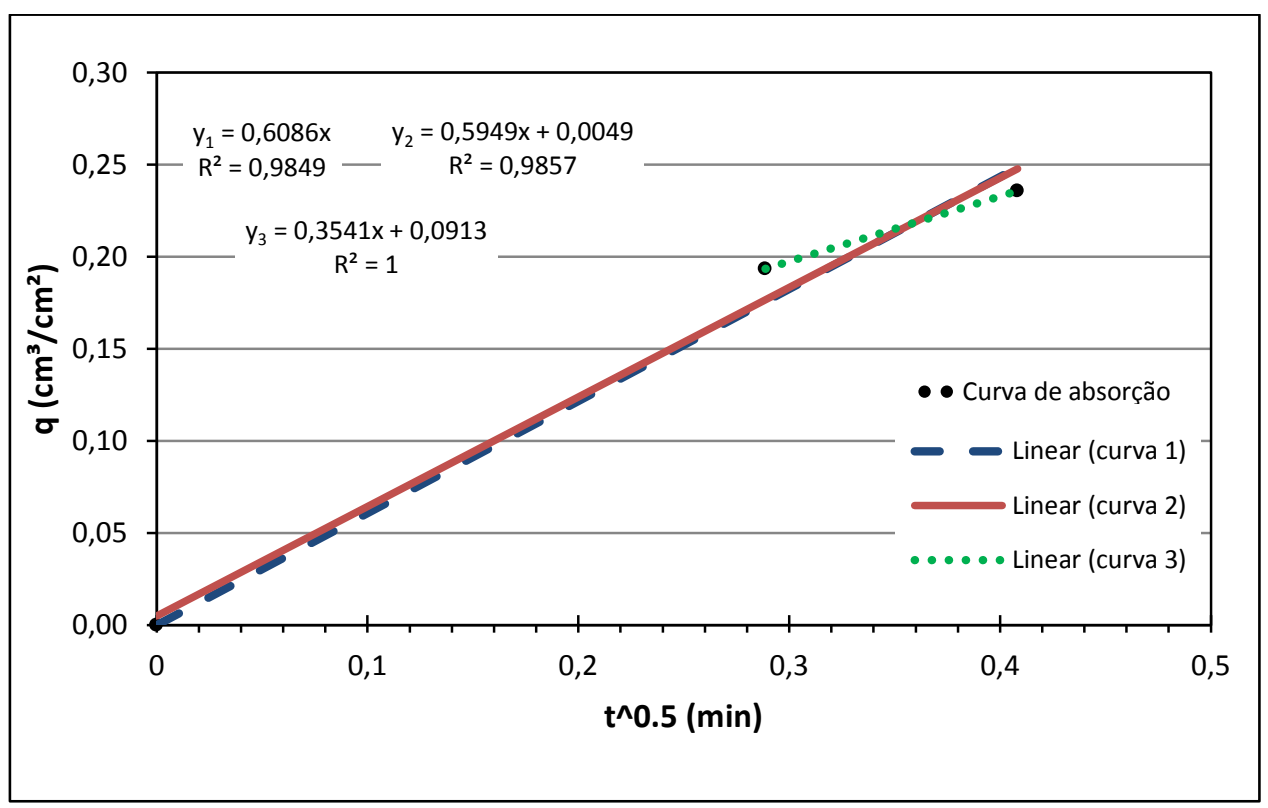

Figura 80 - Curvas de absorção de água - Solo $3[S=5 \mathrm{kPa}]$ 


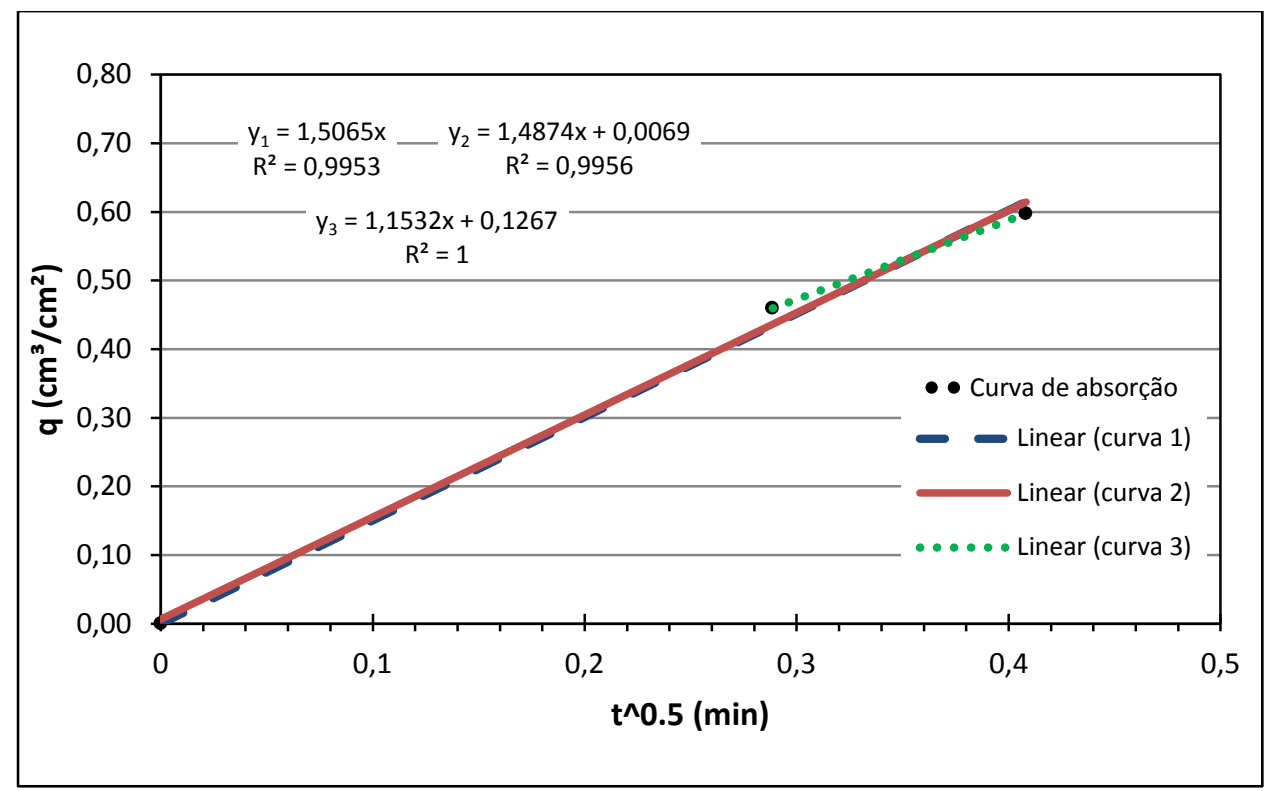

Figura 81- Curvas de absorção de água - Solo 3 [ $\mathrm{S}=10 \mathrm{kPa}$ ]

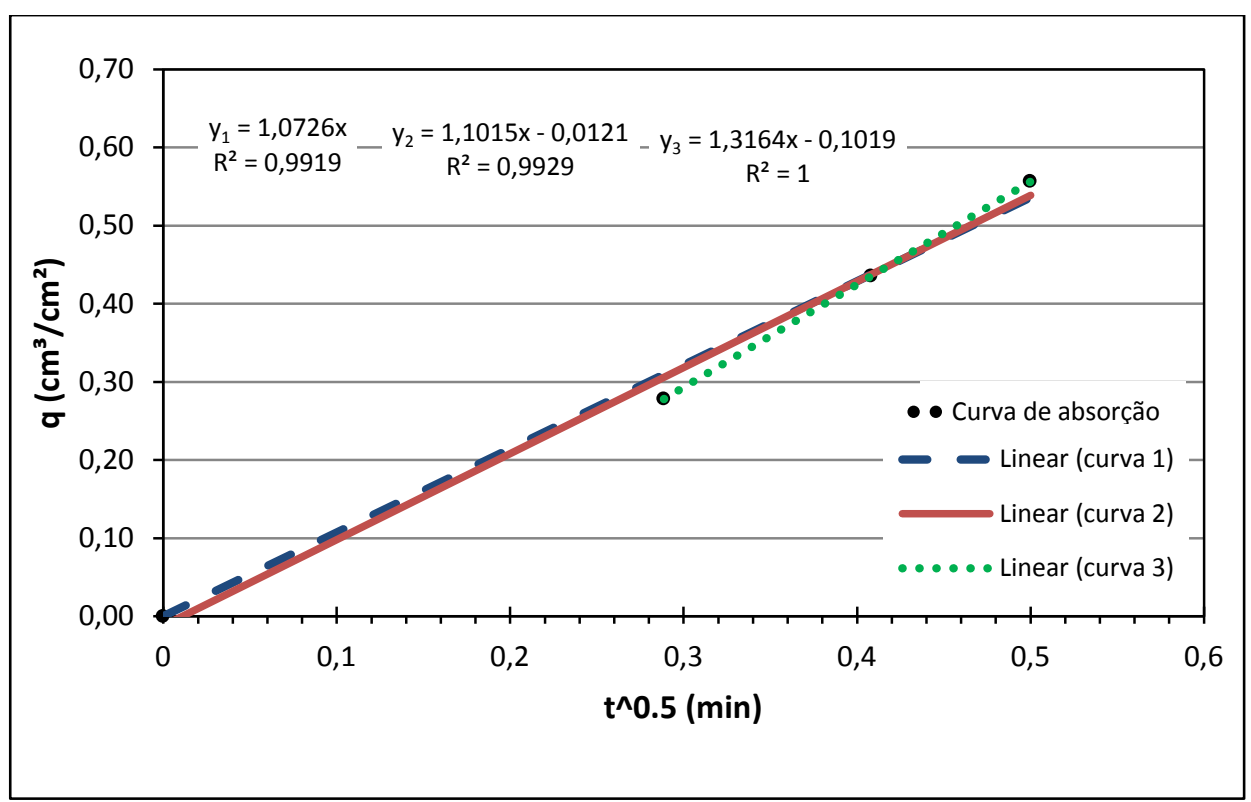

Figura 82 - Curvas de absorção de água - Solo 3 [S = $20 \mathrm{kPa}$ ] 


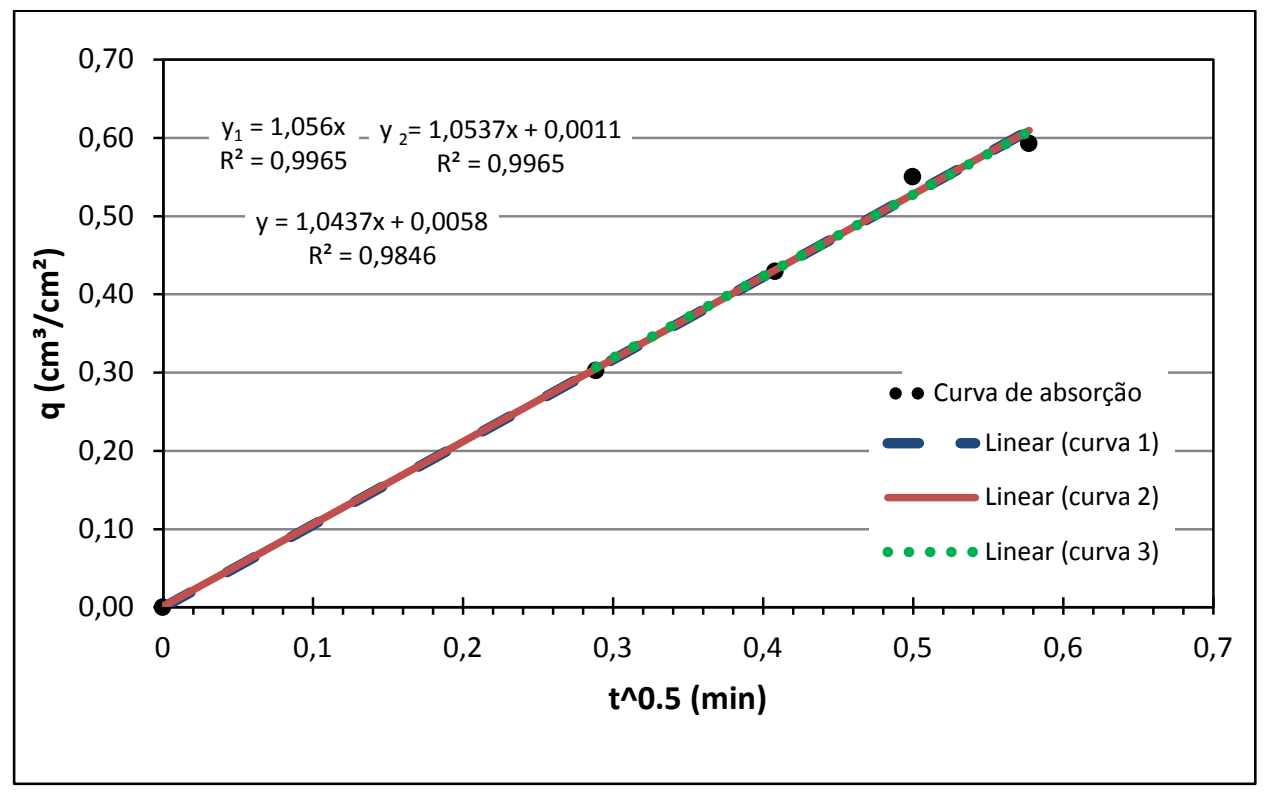

Figura 83 - Curvas de absorção de água - Solo 3 [S = 50 kPa]

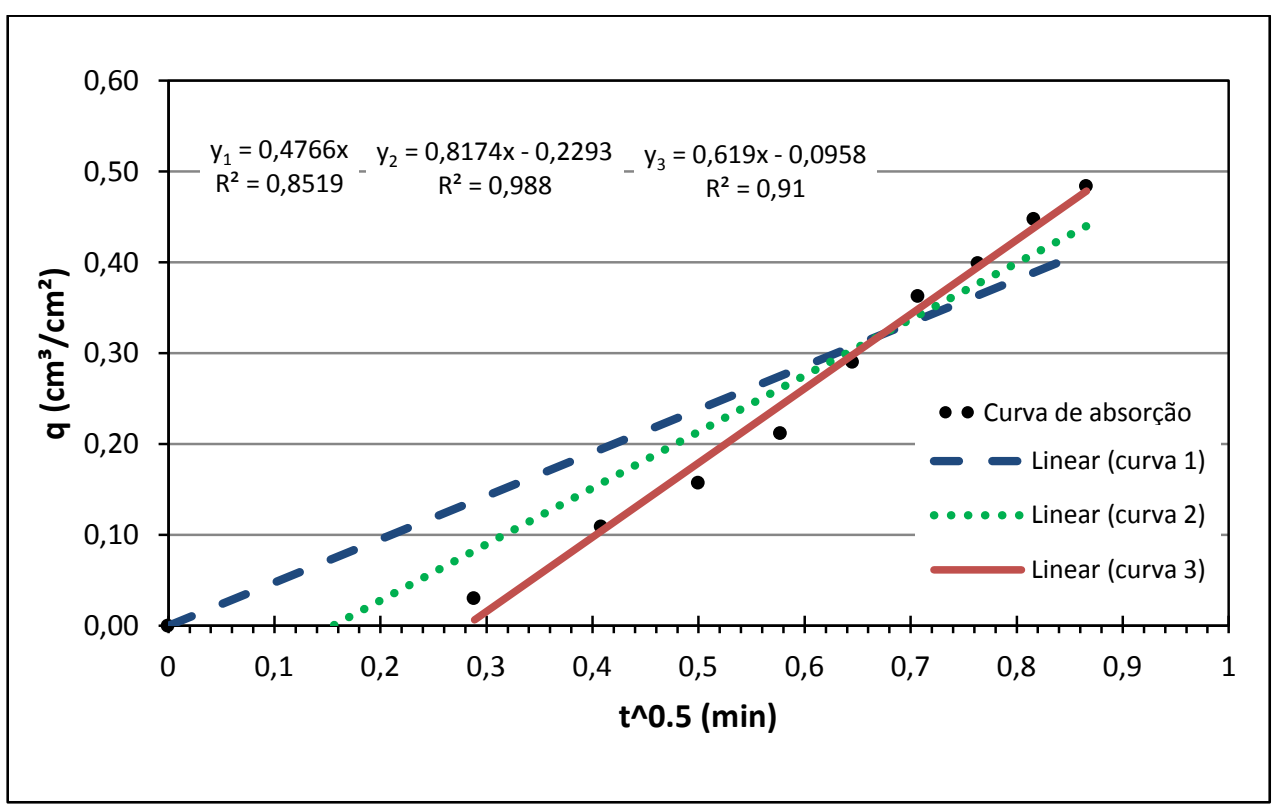

Figura 84 - Curvas de absorção de água - Solo $3[S=100 \mathrm{kPa}]$ 


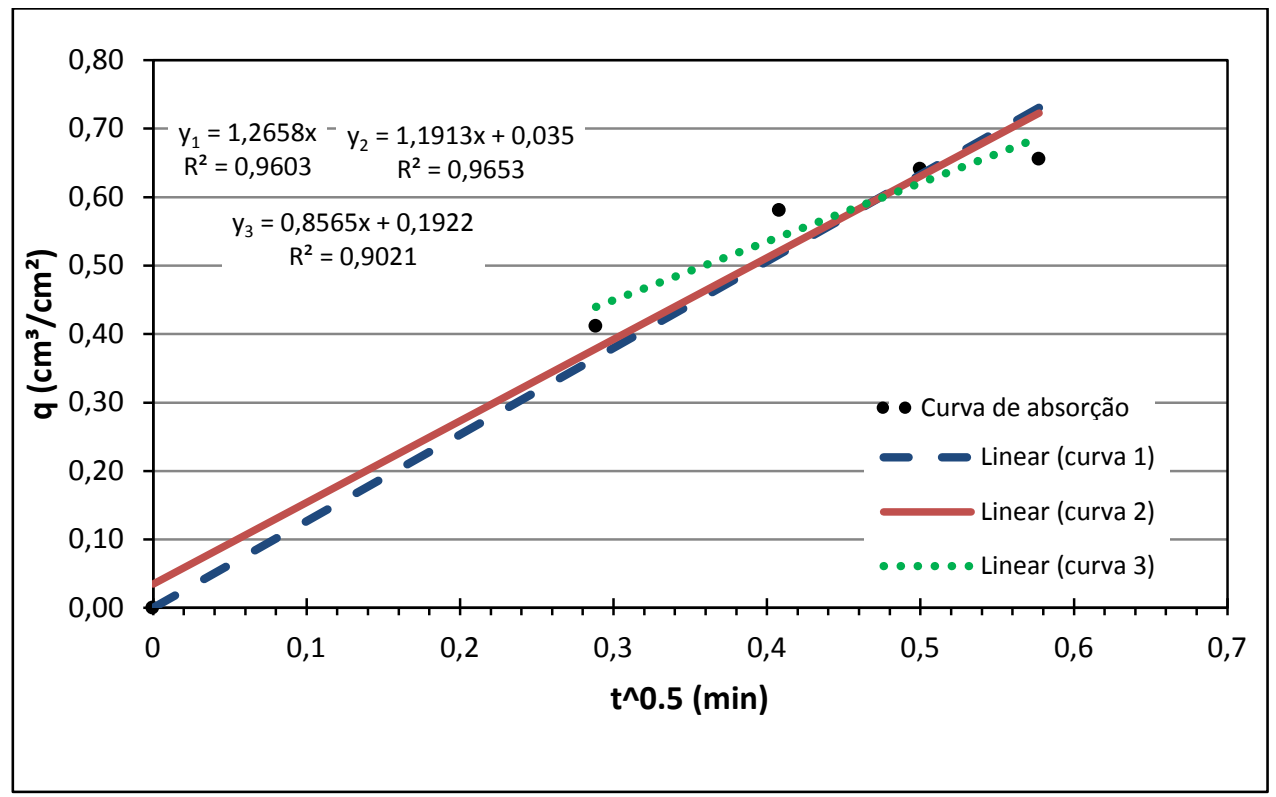

Figura 85 - Curvas de absorção de água - Solo 3 [S = $200 \mathrm{kPa}]$

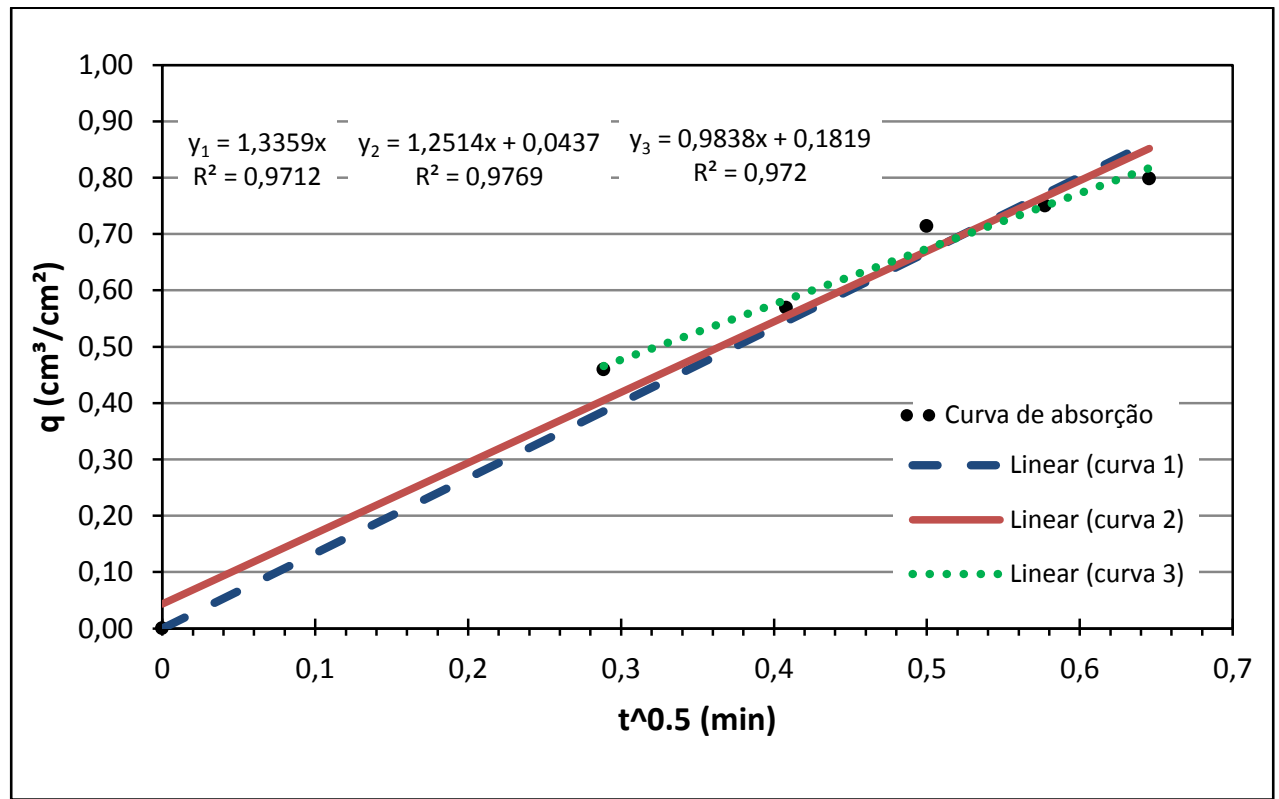

Figura 86 - Curvas de absorção de água - Solo 3 [S = 500 kPa] 


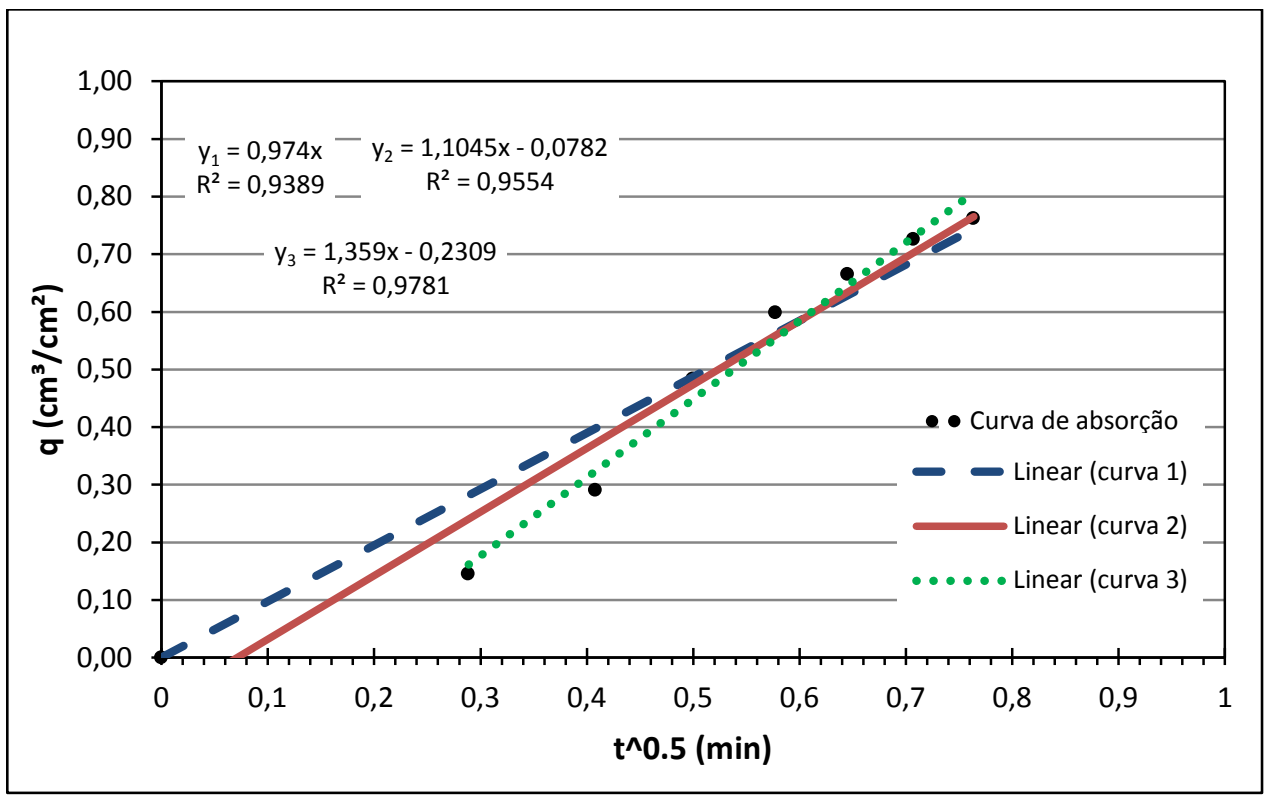

Figura 87 - Curvas de absorção de água - Solo 3 [S = $800 \mathrm{kPa}]$

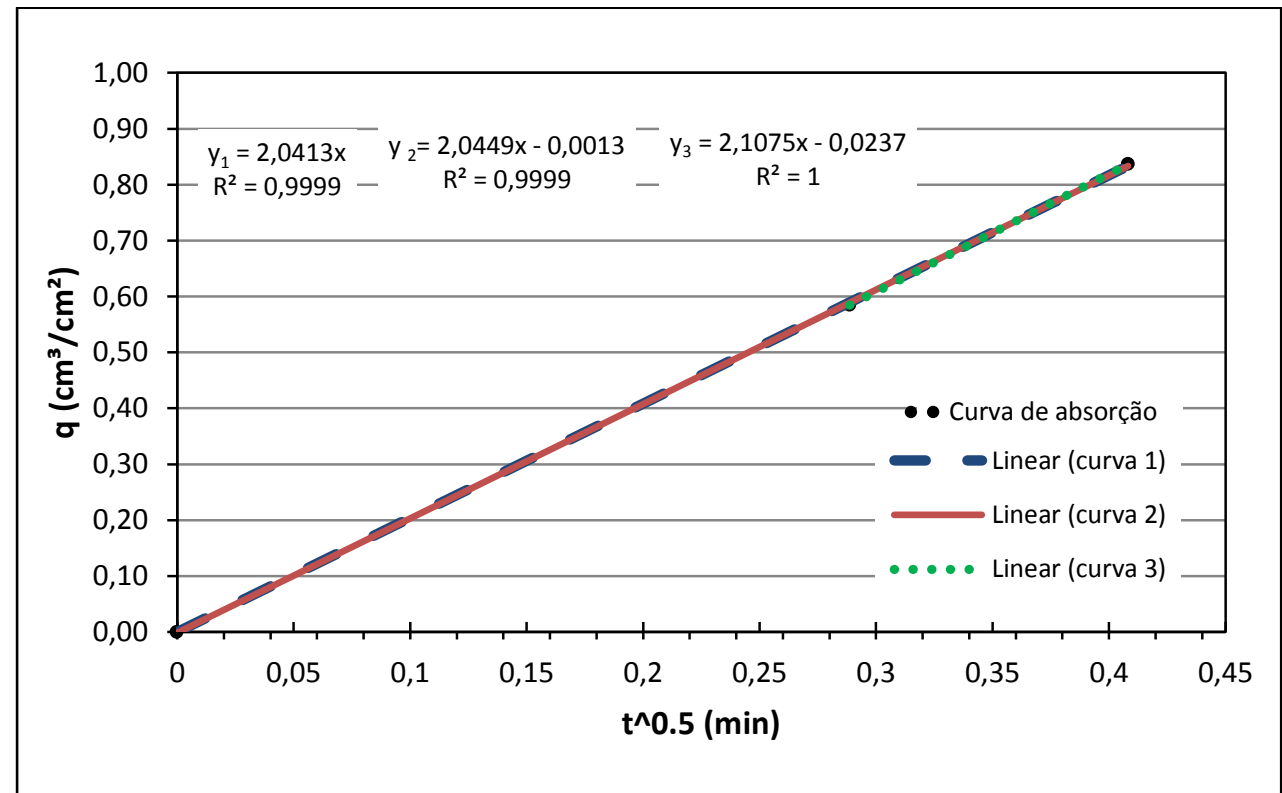

Figura 88 - Curvas de absorção de água - Solo 3 (amostras secas ao ar) - [S > $800 \mathrm{kPa}]$ 